\title{
A Highly Selective Tandem Cross-coupling of Gem-dihaloolefins for a Modular, Efficient Synthesis of Highly Functionalized Indoles
}

\section{Table of Content}

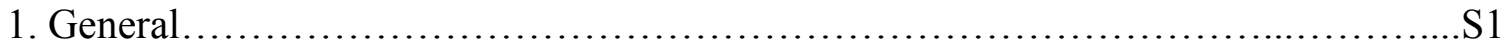

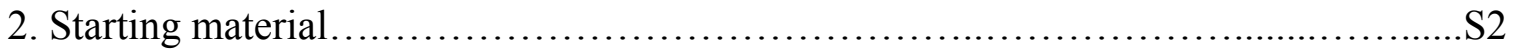

3. Preparation of gemdihalovinylaniline substrates................................. 3

4. Synthesis of 2-substituted, 1,2-disubstituted and 2,3-disubstituted Indoles via Pd-

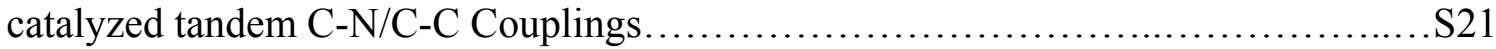

5. Synthesis of 1,2-disubstituted and 1,2,3-trisubstituted indoles via Pd-catalyzed tandem

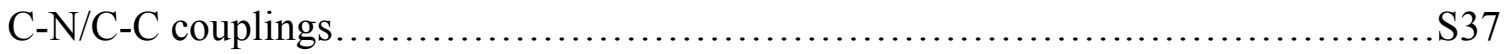

6. Mechanistic evidence for Pd-catalyzed tandem C-N/C-C couplings................S53

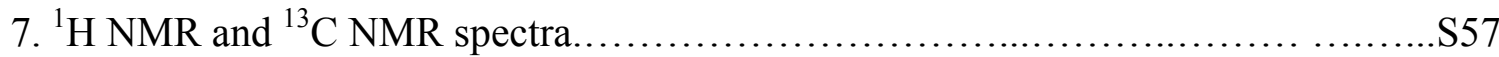

\section{General}

All flasks were flame-dried under a stream of nitrogen or argon and cooled before use unless otherwise noted. Solvents and solutions were transferred with syringes or cannulae using standard inert atmosphere techniques.

${ }^{1} \mathrm{H},{ }^{13} \mathrm{C}$, and ${ }^{19} \mathrm{~F}$ NMR spectra were obtained using a Varian Mercury-300, Gemini300, Unity-400, Mercury 400, or Unity-500 spectrometer. ${ }^{1} \mathrm{H}$ NMR spectra were referenced to tetramethylsilane (TMS, 0 ppm) using $\mathrm{CDCl}_{3}$ as solvent, DMSO-D ${ }_{5}$ residue peaks (2.50 ppm) using DMSO- $\mathrm{d}_{6}$ as solvent, $\mathrm{CHD}_{2} \mathrm{OD}$ residue peaks $(3.30 \mathrm{ppm})$ using $\mathrm{CD}_{3} \mathrm{OD}$ as a solvent. ${ }^{13} \mathrm{C}$ NMR spectra were referenced to solvent carbons $(77.23 \mathrm{ppm}$ for $\mathrm{CDCl}_{3} ; 39.57 \mathrm{ppm}$ for DMSO-d $\mathrm{d}_{6}, 49.15 \mathrm{ppm}$ for $\left.\mathrm{CD}_{3} \mathrm{OD}\right)$. When carbons are equivalent, no special notation is used. ${ }^{19} \mathrm{~F}$ NMR spectra were referenced to $\mathrm{CFCl}_{3}$.

Melting points were taken on a Fisher-Johns melting point apparatus without correction. IR spectra were obtained using a Nicolet DX FT IR spectrometer using thin films of products coated on $\mathrm{NaCl}$ plates. Only absorption frequencies higher than 1000 $\mathrm{cm}^{-1}$ are reported. High-resolution mass spectra were obtained from a VG 70-250S (double focusing) mass spectrometer at $70 \mathrm{eV}$.

Analytical TLC was performed using EM Separations pre-coated silica gel $0.2 \mathrm{~mm}$ layer UV 254 fluorescent sheets. Column chromatography was carried out as "flash 
chromatography" as reported by Still on Ultra Pure Silica Gel (Silicycles, 230-400 mesh, 60A) silica gel using the indicated eluent. Unless otherwise specified, extracts were dried over $\mathrm{MgSO}_{4}$ and volatile solvents were removed with a rotary evaporator at aspirator pressure.

Diethyl ether and toluene were distilled under nitrogen from $\mathrm{Na}$ /benzophenone immediately prior to use. Dichloromethane (DCM) was distilled from $\mathrm{CaH}_{2}$. Dichloromethane and diethyl ether were also purified by passing through a bed of activated molecular sieves using Solvent Purification System.

\section{Starting materials:}

2-Methyl-6-nitrobenzaldehyde, 5-fluoro-2-nitrobenzaldehyde, 4-fluoro-2nitrobenzaldehyde, 3-methyl-2-nitrobenzaldehyde and 1-nitronaphthalene-2carbaldehyde were prepared according to the literature procedure from the corresponding 2-nitrotoluenes via formation of an enamine intermediate using $(\mathrm{MeO})_{2} \mathrm{CHNMe}_{2} / \mathrm{DMF}$ followed by $\mathrm{NaIO}_{4}$ oxidation. 2-Fluoro-6-nitrobenzaldehyde was prepared by NBS radical bromination followed by $\mathrm{DMSO} / \mathrm{NaHCO}_{3}$ oxidation. 2-Nitro-4trifluoromethylbenzaldehyde was prepared from 2-nitro-4-trifluoromethylbenzonitrile using DIBAL-reduction. ${ }^{1}$ 2-Hydroxy-3-methoxy-6-nitrobenzaldehyde (sodium salt) was prepared as a red solid according to the literature procedure ${ }^{2}$ 5-Benzyloxy-2nitrobenzaldehyde was prepared by alkylation of 5-hydroxy-2-nitrobenzaldehyde. ${ }^{3} 2$ 'Nitro-1,1,1-trifluoroacetophenone was prepared from 2-iodonitrobenzene by iodomagnesium exchange followed by trapping with $\left(\mathrm{CF}_{3} \mathrm{CO}\right)_{2} \mathrm{O}{ }^{4}$ 4-Fluoro-2'nitrobenzophenone was prepared by a $\mathrm{FeCl}_{3}$-catalyzed Friedel-Craft reaction from 2nitrobenzoyl chloride and fluorobenzene. ${ }^{5}$ 2-Bromoindole was prepared from indole using directed ortho lithiation followed by trapping with $\mathrm{CCl}_{2} \mathrm{BrCCl}_{2} \mathrm{Br}^{6}$

\footnotetext{
${ }^{1}$ Lewandowska, E.; Kinastowski, S.; Wnuk, S. F. Can. J. Chem. 2002, 80, 192.

${ }^{2}$ Press, J. B.; Bandurco, V. T.; Wong, E. M.; Hajos, Z. G.; Kanojia, R. M.; Mallory, R. A.; Deegan, E. G.; McNally, J. J.; Roberts, J. R.; Cotter, M. L.; Graden, D. W.; Lloyd, J. R. J. Heterocycl. Chem. 1986, 23, 1821.

${ }^{3}$ Astles, P. C.; Brown, T. J.; Halley, F.; Handscombe, C. M.; Harris, N. V.; McCarthy, C.; McLay, I. M.;. Lockey, P.; Majid, T.; Porter, B.; Roach, A. G.; Smith, C.; Walsh, R. J. Med. Chem. 1998, 41, 2745.

${ }^{4}$ O'Dell, D. K.; Nicholas, K. M. Heterocycles 2004, 63, 373.

${ }^{5}$ Maleski, R. J. In Eur. Pat. Appl. Ep 1,431,270, 2004.

${ }^{6}$ Bergman, J.; Venemalm, L. J. Org. Chem. 1992, 57, 2495.
} 


\section{Catalysts and ligands:}

S-Phos was purchased or prepared according to the literature procedure. Degussa catalyst $[1 \% \mathrm{Pt}$ on activated carbon, vanadium doped (50\% wetted powder) (abbreviated as $1 \% \mathrm{Pt}-\mathrm{C}[\mathrm{V}])]$ was purchased from Strem or received as a gift from Deguss.

\section{Preparation of Gemdihalovinylaniline Substrates}

\section{2-(2,2-Dibromovinyl)-phenylamine (1a)}

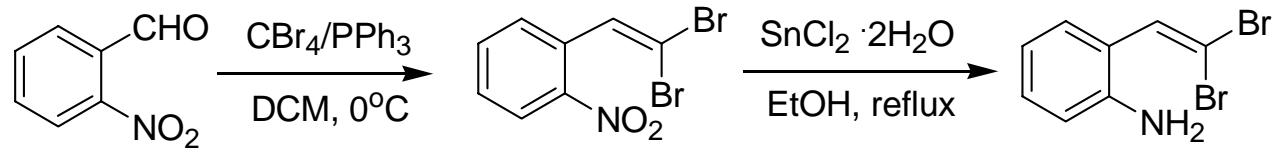

General procedure for one-pot synthesis of 2-gemdibromovinylanilines: To a solution of 2-nitrobenzaldehyde (9.07 g, $60 \mathrm{mmol})$ and $\mathrm{CBr}_{4}(29.8 \mathrm{~g}, 90 \mathrm{mmol})$ in DCM $(300 \mathrm{~mL})$ at $0{ }^{\circ} \mathrm{C}$ was added dropwise a solution of $\mathrm{PPh}_{3}(47.2 \mathrm{~g}, 180 \mathrm{mmol})$ in DCM $(200 \mathrm{~mL})$ by an addition funnel. The addition rate was controlled so that the internal temperature was at $1-5^{\circ} \mathrm{C}$. After addition $(\sim 1 \mathrm{~h})$, the mixture was stirred for another $0.5 \mathrm{~h}$ before warmed to rt, and stirred for an additional $1 \mathrm{~h}$. The reaction mixture was filtered through a short plug of silica gel (120 g), and was washed with a copious amount of DCM until no product was found. Solvent was removed under vacuum to give a mixture of the desired intermediate and triphenylphosphine oxide. To the mixture $(\sim 50 \mathrm{~g})$ was added $\mathrm{EtOH}(95 \%, 200 \mathrm{~mL})$ and $\mathrm{SnCl}_{2} \cdot \mathrm{H}_{2} \mathrm{O}(67.7 \mathrm{~g}, 300 \mathrm{mmol})$. The suspension was heated at $100{ }^{\circ} \mathrm{C}$ (reflux) for $45 \mathrm{~min}$, and then cooled to rt. After most of the ethanol was removed under vacuum, $\mathrm{H}_{2} \mathrm{O}(150 \mathrm{~mL})$ and EtOAc $(150 \mathrm{~mL})$ were added. To the resulting mixture, solid $\mathrm{K}_{2} \mathrm{CO}_{3}$ was added carefully until $\mathrm{pH}>10$. The EtOAc layer was separated from the heterogeneous mixture, and the aqueous phase was extracted with EtOAc until it was free of the product $(5 \times 100 \mathrm{~mL})$. The combined organic solution was washed with brine and dried over $\mathrm{Na}_{2} \mathrm{SO}_{4} / \mathrm{K}_{2} \mathrm{CO}_{3}$. Solvent was removed under vacuum and the residue was redissolved in $\mathrm{Et}_{2} \mathrm{O}$. The resulting precipitated $\mathrm{Ph}_{3} \mathrm{P}(\mathrm{O})$ was removed by filtration. The product was further purified by flash chromatography using $10 \%$ EtOAc in hexanes. The product was obtained as an off white solid $(14.2 \mathrm{~g}, 85 \%$ over 2 steps). mp 40-42 ${ }^{\circ} \mathrm{C} .{ }^{1} \mathrm{H}$ NMR $\left(300 \mathrm{MHz}, \mathrm{CDCl}_{3}\right) \delta 7.33(1 \mathrm{H}, \mathrm{s}), 7.30(1 \mathrm{H}, \mathrm{d}, J=7.7 \mathrm{~Hz})$, $7.16(1 \mathrm{H}$, ddd, $J=7.7,7.7,1.4 \mathrm{~Hz}), 6.78(1 \mathrm{H}, \mathrm{t}, J=7.6 \mathrm{~Hz}), 6.70(1 \mathrm{H}, \mathrm{dd}, J=8.0,0.8$ 
$\mathrm{Hz}), 3.70(2 \mathrm{H}, \mathrm{br}) .{ }^{13} \mathrm{C}$ NMR $\left(75 \mathrm{MHz}, \mathrm{CDCl}_{3}\right) \delta 143.8,134.3,129.9,129.4,122.0$, 118.6, 116.0, 93.0.

\section{2-(2,2-Dibromovinyl)-3-methylphenylamine (1b)}<smiles>Cc1cccc([N+](=O)[O-])c1C=O</smiles><smiles>C=CCCCCCCCCCCCCCCCCC</smiles>

The general procedure was followed using 2-methyl-6-nitrobenzaldehyde (6 mmol scale). The product was obtained as an off-white solid by flash chromatography using $5 \%$ EtOAc in hexanes (1.21 g, 69\% over 2 steps). $\mathrm{R}_{\mathrm{f}}=0.21$ (5\% EtOAc in hexanes). mp 42$43{ }^{\circ} \mathrm{C}$. IR (neat, $\mathrm{cm}^{-1}$ ): 3461, 3377, 2986, 1612, 1579, 1467, 1302. ${ }^{1} \mathrm{H}$ NMR (400 MHz, $\left.\mathrm{CDCl}_{3}\right) \delta 7.30(1 \mathrm{H}, \mathrm{s}), 7.06(1 \mathrm{H}, \mathrm{t}, J=7.8 \mathrm{~Hz}), 6.62(1 \mathrm{H}, \mathrm{d}, J=7.5 \mathrm{~Hz}), 6.56(1 \mathrm{H}, \mathrm{d}, J=$ $7.9 \mathrm{~Hz}), 3.69$ (2H, br), $2.20(3 \mathrm{H}, \mathrm{s}) .{ }^{13} \mathrm{C} \mathrm{NMR}\left(100 \mathrm{MHz}, \mathrm{CDCl}_{3}\right) \delta 143.4,137.0,135.3$, 129.3, 122.1, 120.2, 113.2, 94.9, 20.2. HRMS (ESI) calc'd for $\mathrm{C}_{9} \mathrm{H}_{10} \mathrm{Br}_{2} \mathrm{~N}\left([\mathrm{M}+\mathrm{H}]^{+}\right)$: 289.9174. Found: 289.9161.

\section{2-(2,2-Dibromovinyl)-3-fluorophenylamine (1c)}<smiles>O=Cc1c(F)cccc1[N+](=O)[O-]</smiles><smiles>C=C1CC1C</smiles><smiles>Nc1cccc(F)c1C=C(Br)Br</smiles>

The general procedure was followed using 2-fluoro-6-nitrobenzaldehyde (6.5 mmol scale). The product was obtained as an off-white semi-solid by flash chromatography using $10 \%$ EtOAc in hexanes (1.56 g, 81\% over 2 steps). $\mathrm{R}_{\mathrm{f}}=0.20$ (10\% EtOAc in hexanes). IR (neat, $\mathrm{cm}^{-1}$ ): 3479, 3391, 1626, 1579, 1464, 1318, 1243, 1116, 1056. ${ }^{1} \mathrm{H}$ NMR (400 MHz, $\left.\mathrm{CDCl}_{3}\right) \delta 7.20(1 \mathrm{H}, \mathrm{s}), 7.10$ (1H, dddd, $\left.J=8.2,8.2,6.4,0.7 \mathrm{~Hz}\right), 7.49$ $6.45(2 \mathrm{H}, \mathrm{m}), 3.85(2 \mathrm{H}, \mathrm{br}) .{ }^{13} \mathrm{C} \mathrm{NMR}\left(100 \mathrm{MHz} \mathrm{CDCl}_{3}\right) \delta 160.1\left(J_{\mathrm{C}-\mathrm{F}}=246 \mathrm{~Hz}\right), 145.3$ $\left(J_{\mathrm{C}-\mathrm{F}}=5.7 \mathrm{~Hz}\right), 130.6\left(J_{\mathrm{C}-\mathrm{F}}=10.5 \mathrm{~Hz}\right), 129.4\left(J_{\mathrm{C}-\mathrm{F}}=1.5 \mathrm{~Hz}\right), 111.1\left(J_{\mathrm{C}-\mathrm{F}}=2.7 \mathrm{~Hz}\right), 110.5$ $\left(J_{\mathrm{C}-\mathrm{F}}=19.5 \mathrm{~Hz}\right), 105.2\left(J_{\mathrm{C}-\mathrm{F}}=22.1 \mathrm{~Hz}\right), 96.7\left(J_{\mathrm{C}-\mathrm{F}}=1.7 \mathrm{~Hz}\right) .{ }^{19} \mathrm{~F} \mathrm{NMR}(376 \mathrm{MHz}$, 
$\left.\mathrm{CDCl}_{3}\right) \delta$-112.2. HRMS (ESI) calc'd for $\mathrm{C}_{8} \mathrm{H}_{7} \mathrm{NFBr}_{2}\left([\mathrm{M}+\mathrm{H}]^{+}\right)$293.8923. Found: 293.8919.

\section{3-Benzyloxy-2-(2,2-dibromovinyl)-4-methoxyphenylamine (1d)}

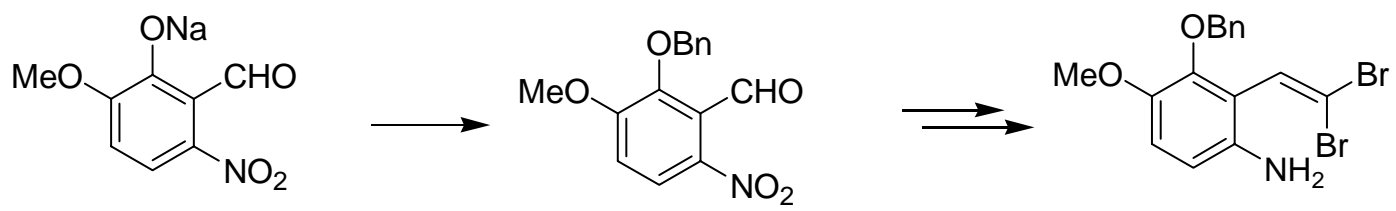

The sodium salt of 2-hydroxy-3-methoxy-6-nitrobenzaldehyde (3.89 g, $17.8 \mathrm{mmol}$ ) was suspended in a mixed solvent of DMF $(20 \mathrm{~mL})$ and $\mathrm{CH}_{3} \mathrm{CN}(20 \mathrm{~mL}) . \mathrm{K}_{2} \mathrm{CO}_{3}(0.5 \mathrm{~g})$ and $\mathrm{BnBr}(3.42 \mathrm{~g}, 20 \mathrm{mmol})$ were added, and the resulting mixture was heated to $100{ }^{\circ} \mathrm{C}$ for $4 \mathrm{~h}$ until the red-colored suspension disappeared. The mixture was cooled to $\mathrm{rt}, \mathrm{H}_{2} \mathrm{O}$ added $(50 \mathrm{~mL})$, and extracted with DCM/EtOAc. The organic phase was dried over $\mathrm{MgSO}_{4}$ and solvent was removed under vacuum. The product 2-benzyloxy-3-methoxy-6nitrobenzaldehyde was obtained as a white crystalline solid by recrystallization from $5 \%$ EtOAc in hexanes and washed with small amount of $\mathrm{Et}_{2} \mathrm{O}(5.0 \mathrm{~g}, 98 \%)$. ${ }^{1} \mathrm{H}$ NMR (300 $\left.\mathrm{MHz} \mathrm{CDCl}_{3}\right) \delta 10.2(1 \mathrm{H}, \mathrm{s}), 7.96(1 \mathrm{H}, \mathrm{d}, J=9.1 \mathrm{~Hz}), 7.43-7.32(5 \mathrm{H}, \mathrm{m}), 7.06(1 \mathrm{H}, \mathrm{d}, J=$ $9.2 \mathrm{~Hz}), 5.07(2 \mathrm{H}, \mathrm{s}), 4.02(3 \mathrm{H}, \mathrm{s})$.

The general procedure was followed using 2-benzyloxy-3-methoxy-6nitrobenzaldehyde (11.56 mmol scale). The product was obtained as an off-white solid by flash chromatography using $10 \%$ EtOAc in hexanes $\left(3.44 \mathrm{~g}, 72 \%\right.$ over 2 steps). $\mathrm{R}_{\mathrm{f}}=0.16$ (20\% EtOAc in hexanes). $\mathrm{mp} 96-97^{\circ} \mathrm{C}$. IR (neat, $\mathrm{cm}^{-1}$ ): 3451, 3366, 2940, 1617, 1487 , 1441, 1266, 1126, 1076, 1226. ${ }^{1} \mathrm{H}$ NMR (300 MHz, $\left.\mathrm{CDCl}_{3}\right) \delta$ 7.46-7.28 (5H, m), 7.17 $(1 \mathrm{H}, \mathrm{s}), 6.83(1 \mathrm{H}, \mathrm{d}, J=8.7 \mathrm{~Hz}), 6.45(1 \mathrm{H}, \mathrm{d}, J=8.7 \mathrm{~Hz}), 4.98(2 \mathrm{H}, \mathrm{s}), 3.82(3 \mathrm{H}, \mathrm{s}), 3.51$ $\left(2 \mathrm{H}\right.$, br). ${ }^{13} \mathrm{C}$ NMR $\left(75 \mathrm{MHz}, \mathrm{CDCl}_{3}\right) \delta 145.9,145.6,138.0,137.7,133.0,128.7,128.6$, 128.2, 118.6, 115.1, 111.2, 94.7, 75.3, 57.0. HRMS (EI) calc'd for $\mathrm{C}_{16} \mathrm{H}_{15} \mathrm{NO}_{2} \mathrm{Br}_{2}\left([\mathrm{M}]^{+}\right)$ 410.9470. Found: 410.9470.

\section{2-(2,2-Dibromovinyl)-4-fluorophenylamine (1e)}




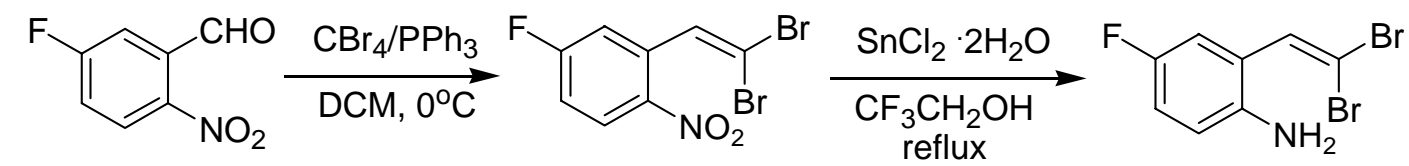

The general procedure of preparing 2-gemdibromovinylnitrobenzene was followed using 5-fluoro-2-nitrobenzaldehyde (10 mmol scale) to afford the intermediate $(3.1 \mathrm{~g}$, 95\%) after chromatographic purification (5\% EtOAc in hexanes). The nitro intermediate (0.416 g, $1.28 \mathrm{mmol})$ and $\mathrm{SnCl}_{2} \cdot 2 \mathrm{H}_{2} \mathrm{O}(1.45 \mathrm{~g}, 6.40 \mathrm{mmol})$ in 1,1,1-trifluoroethanol (7 $\mathrm{mL})$ was heated to reflux for $8 \mathrm{~h}$. The mixture was taken into $\mathrm{H}_{2} \mathrm{O} / \mathrm{Et}_{2} \mathrm{O}(20 \mathrm{~mL} / 20 \mathrm{~mL})$ and neutralized with $\mathrm{K}_{2} \mathrm{CO}_{3}$. After extraction with $\mathrm{Et}_{2} \mathrm{O}(3 \times 20 \mathrm{~mL})$, the product was purified by flash chromatography using $10 \%$ EtOAc in hexane. The product was obtained as a colorless oil $(0.303 \mathrm{~g}, 80 \%) . \mathrm{R}_{\mathrm{f}}=0.20\left(10 \%\right.$ EtOAc in hexanes). IR (neat, $\left.\mathrm{cm}^{-1}\right)$ : 3453, 3378, 3001, 1626, 1493, 1434, 1260, 1207, 1151. ${ }^{1} \mathrm{H}$ NMR (300 MHz, $\left.\mathrm{CDCl}_{3}\right) \delta$ 7.29 (1H, s), 7.07 (1H, dd, $J=9.4,2.7 \mathrm{~Hz}), 6.89$ (1H, ddd, $J=8.4,8.4,3.0 \mathrm{~Hz}), 6.64(1 \mathrm{H}$, $\mathrm{dd}, J=8.8,4.7 \mathrm{~Hz}), 3.58(2 \mathrm{H}, \mathrm{br}) .{ }^{13} \mathrm{C} \mathrm{NMR}\left(75 \mathrm{MHz}, \mathrm{CDCl}_{3}\right) \delta 155.9\left(J_{\mathrm{CF}}=237 \mathrm{~Hz}\right)$, $140.0\left(J_{\mathrm{CF}}=2.0 \mathrm{~Hz}\right), 133.2\left(J_{\mathrm{CF}}=1.7 \mathrm{~Hz}\right), 122.8\left(J_{\mathrm{CF}}=7.7 \mathrm{~Hz}\right), 117.1\left(J_{\mathrm{CF}}=8.0 \mathrm{~Hz}\right)$, $116.7\left(J_{\mathrm{CF}}=22.6 \mathrm{~Hz}\right), 115.6\left(J_{\mathrm{CF}}=23.5 \mathrm{~Hz}\right), 93.9 .{ }^{19} \mathrm{~F} \mathrm{NMR}\left(282 \mathrm{MHz}, \mathrm{CDCl}_{3}\right) \delta-125.8$. HRMS (ESI) calc'd for $\mathrm{C}_{8} \mathrm{H}_{7} \mathrm{NFBr}_{2}\left([\mathrm{M}+\mathrm{H}]^{+}\right)$293.8923. Found: 293.8923.

\section{4-Benzyloxy-2-(2,2-dibromovinyl)phenylamine (1f)}<smiles>O=Cc1cc(OCc2ccccc2)ccc1[N+](=O)[O-]</smiles><smiles>C=C[C@H](C)CCc1ccc(N)c(C=C(Br)Br)c1</smiles>

The general procedure was followed using 5-benzyloxy-2-nitrobenzaldehyde (7 mmol scale). The product was obtained as a white solid by flash chromatography using $10 \%$ EtOAc in hexanes $\left(2.04 \mathrm{~g}, 76 \%\right.$ over 2 steps). $\mathrm{R}_{\mathrm{f}}=0.15$ (10\% EtOAc in hexanes). $\mathrm{mp}$ 67$68{ }^{\circ} \mathrm{C}$. IR (neat, $\mathrm{cm}^{-1}$ ): 3423, 3353, 1603, 1499, 1426, 1260, 1229, 1001. ${ }^{1} \mathrm{H}$ NMR (300 $\left.\mathrm{MHz} \mathrm{CDCl}_{3}\right) \delta$ 7.43-7.26 (6H, m), $6.97(1 \mathrm{H}, \mathrm{d}, J=2.7 \mathrm{~Hz}), 6.84(1 \mathrm{H}, \mathrm{dd}, J=8.8,3.0$ $\mathrm{Hz}), 6.64(1 \mathrm{H}, \mathrm{d}, J=8.8 \mathrm{~Hz}), 5.00(2 \mathrm{H}, \mathrm{s}), 3.44(2 \mathrm{H}, \mathrm{br}) .{ }^{13} \mathrm{C} \mathrm{NMR}\left(75 \mathrm{MHz}, \mathrm{CDCl}_{3}\right) \delta$ 151.6, 137.9, 137.4, 134.0, 128.7, 128.1, 127.7, 122.8, 117.7, 117.4, 115.3, 92.9, 71.0. HRMS (ESI) calc'd for $\mathrm{C}_{15} \mathrm{H}_{14} \mathrm{NOBr}_{2}\left([\mathrm{M}+\mathrm{H}]^{+}\right)$381.9436. Found: 381.9425 . 


\section{4-Amino-3-(2,2-dibromovinyl)-benzoic acid methyl ester (1g)}

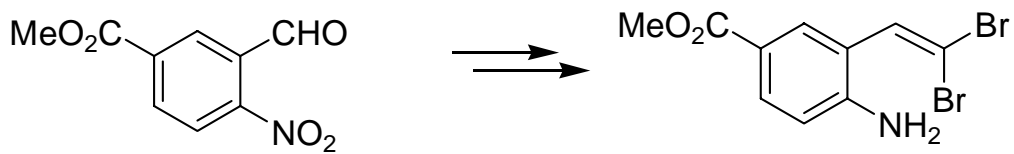

The general procedure was followed using methyl 5-formyl-4-nitrobenzoate (6.5 mmol scale). The product was obtained as a yellowish solid by flash chromatography using $20 \rightarrow 30 \%$ EtOAc in hexanes (1.917 g, 88\% over 2 steps). $\mathrm{R}_{\mathrm{f}}=0.20$ (20\% EtOAc in hexanes). $\mathrm{mp} 112-113{ }^{\circ} \mathrm{C}$. IR (neat, $\mathrm{cm}^{-1}$ ): 3476, 3368, 3244, 2950, 1698, 1623, 1502 , 1437, 1289, 1243, 1198, 1149, 1106. ${ }^{1} \mathrm{H}$ NMR (400 MHz, $\left.\mathrm{CDCl}_{3}\right) \delta 7.97(1 \mathrm{H}, \mathrm{d}, J=1.8$ Hz), $7.84(1 \mathrm{H}, \mathrm{dd}, J=8.5,1.9 \mathrm{~Hz}), 7.29(1 \mathrm{H}, \mathrm{s}), 6.98(1 \mathrm{H}, \mathrm{d}, J=8.4 \mathrm{~Hz}), 4.14(2 \mathrm{H}, \mathrm{br})$, $3.86(3 \mathrm{H}, \mathrm{s}) .{ }^{13} \mathrm{C} \mathrm{NMR}\left(75 \mathrm{MHz}, \mathrm{CDCl}_{3}\right) \delta 167.0,147.9,133.2,131.8,131.7,120.8$, 120.0, 114.9, 94.8, 52.0. HRMS (EI) calc'd for $\mathrm{C}_{10} \mathrm{H}_{9} \mathrm{NO}_{2} \mathrm{Br}_{2}\left([\mathrm{M}]^{+}\right)$332.9000. Found: 332.9004 .

\section{4,5-Bisbenzyloxy-2-(2,2-dibromovinyl)-phenylamine (1h)}<smiles>Nc1cc(OBr)c(OBr)cc1C=O</smiles><smiles>Nc1cc(OCc2ccccc2)c(OCBr)cc1C=C(Br)Br</smiles>

The general procedure was followed using 4,5-bisbenzyloxy-2-nitrobenzaldehyde (5 mmol scale). The product was obtained as an off-white solid by flash chromatography using 20\% EtOAc in hexanes (1.01 g, 41\% over 2 steps). $\mathrm{R}_{\mathrm{f}}=0.21(20 \%$ EtOAc in hexanes). mp 95-98 ${ }^{\circ} \mathrm{C}$. IR (neat, $\mathrm{cm}^{-1}$ ): 3445, 3372, 1614, 1505, 1454, 1427, 1290, 1213, 1125. ${ }^{1} \mathrm{H}$ NMR $\left(400 \mathrm{MHz}, \mathrm{CDCl}_{3}\right) \delta$ 7.43-7.24 (10H, m), $7.20(1 \mathrm{H}, \mathrm{s}), 6.99(1 \mathrm{H}, \mathrm{s}), 6.28$ $(1 \mathrm{H}, \mathrm{s}), 5.10(2 \mathrm{H}, \mathrm{s}), 5.06(2 \mathrm{H}, \mathrm{s}), 3.44(2 \mathrm{H}, \mathrm{br}) .{ }^{13} \mathrm{C}$ NMR $\left(100 \mathrm{MHz}, \mathrm{CDCl}_{3}\right) \delta 151.0$, 141.2 , 139.4, 137.8, 137.2, 133.3, 128.8, 128.6, 128.1, 127.9, 127.8, 127.4, 117.9, 114.1, 103.1, 91.4, 72.9, 71.1. Anal. Calc'd for $\mathrm{C}_{22} \mathrm{H}_{19} \mathrm{Br}_{2} \mathrm{NO}_{2}$ : C, 54.01; H, 3.91; N, 2.86 . Found: C, 54.31; H, 4.24; N, 2.94 .

\section{5-Benzyloxy-2-(2,2-dibromovinyl)-phenylamine (1i)}


<smiles>C=CC=CCCCCCCCCCCCOc1ccc(C=O)c([N+](=O)[O-])c1</smiles>

A mixture of 4-methyl-3-nitrophenol (2.53 g, $16.5 \mathrm{mmol}), \mathrm{BnBr}(2.83 \mathrm{~g}, 19.8 \mathrm{mmol})$, $\mathrm{K}_{2} \mathrm{CO}_{3}(2.75 \mathrm{~g}, 19.8 \mathrm{mmol})$, and tetrabutylammonium iodide $(0.61 \mathrm{~g}, 1.65 \mathrm{mmol})$ in DMF $(15 \mathrm{~mL})$ was stirred at $\mathrm{rt}$ for $18 \mathrm{~h}$. The mixture was diluted with $\mathrm{Et}_{2} \mathrm{O}(40 \mathrm{~mL})$, washed with $\mathrm{H}_{2} \mathrm{O}(20 \mathrm{~mL}), \mathrm{NaOH}(1 \mathrm{M}, 10 \mathrm{~mL}), \mathrm{H}_{2} \mathrm{O}(20 \mathrm{~mL}), \mathrm{NaHCO}_{3}(20 \mathrm{~mL})$, brine (20 $\mathrm{mL}$ ), and dried over $\mathrm{MgSO}_{4}$. The mixture was further purified by flash chromatography using 10\% EtOAc in hexanes to afford the product as a slightly yellow solid (4.0 g, 100\%). This intermediate was converted into the corresponding aldehyde according to the literature procedure by reacting with $(\mathrm{MeO})_{2} \mathrm{CHNMe}_{2}(5.9 \mathrm{~g}, 49.3$ mmol) in DMF $(10 \mathrm{~mL})$ at $140^{\circ} \mathrm{C}$ for $60 \mathrm{~h}$, followed by oxidation with $\mathrm{NaIO}_{4}(10.5 \mathrm{~g}$, $49.3 \mathrm{mmol}$ ). The product 4-benzyloxy-2-nitrobenzaldehyde was obtained as a slightly yellow solid by flash chromatography using $20 \%$ EtOAc in hexanes $(3.33 \mathrm{~g}, 79 \%) .{ }^{1} \mathrm{H}$ NMR $\left(300 \mathrm{MHz}, \mathrm{CDCl}_{3}\right) \delta 10.3(1 \mathrm{H}, \mathrm{s}), 7.96(1 \mathrm{H}, \mathrm{d}, J=8.8 \mathrm{~Hz}), 7.59(1 \mathrm{H}, \mathrm{d}, J=2.5$ $\mathrm{Hz}), 7.43-7.27(5 \mathrm{H}, \mathrm{m}), 7.28(1 \mathrm{H}, \mathrm{dd}, J=8.6,2.5 \mathrm{~Hz}), 5.20(2 \mathrm{H}, \mathrm{s})$.

The general procedure was followed using 4-benzyloxy-2-nitrobenzaldehyde (7.5 mmol scale). The product was obtained as a light tan solid by flash chromatography using $10 \%$ EtOAc in hexanes $(2.35 \mathrm{~g}, 82 \%$ over 2 steps $) . \mathrm{R}_{\mathrm{f}}=0.20$ (10\% EtOAc in hexanes). mp 93-94 ${ }^{\circ} \mathrm{C}$. IR (neat, $\mathrm{cm}^{-1}$ ): 3470, 3383, 1615, 1572, 1502, 1300, 1187, 1016. ${ }^{1} \mathrm{H}$ NMR $\left(400 \mathrm{MHz}, \mathrm{CDCl}_{3}\right) \delta 7.42-7.30(5 \mathrm{H}, \mathrm{m}), 7.25(2 \mathrm{H}, \mathrm{m}), 6.43(1 \mathrm{H}, \mathrm{dd}, J=8.7,2.3 \mathrm{~Hz})$, $6.30(1 \mathrm{H}, \mathrm{d}, J=2.4 \mathrm{~Hz}), 5.02(2 \mathrm{H}, \mathrm{s}), 3.69(2 \mathrm{H}, \mathrm{br}) .{ }^{13} \mathrm{C} \mathrm{NMR}\left(100 \mathrm{MHz}, \mathrm{CDCl}_{3}\right) \delta$ $160.3,145.3,137.1,133.7,130.6,128.8,128.2,127.7,115.2,105.4,102.0,91.8,70.1$. HRMS (ESI) calc'd for $\mathrm{C}_{15} \mathrm{H}_{14} \mathrm{NOBr}_{2}\left([\mathrm{M}+\mathrm{H}]^{+}\right)$381.9436. Found: 381.9455.

\section{2-(2,2-Dibromovinyl)-5-fluorophenylamine (1j)}

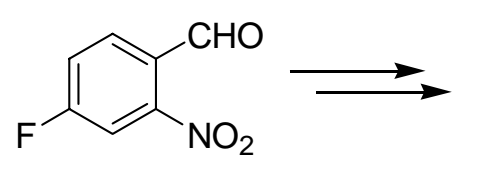<smiles>Nc1cc(F)ccc1C=C(Br)Br</smiles> 
The general procedure was followed using 4-fluoro-2-nitrobenzaldehyde (10 mmol scale). The product was obtained as an off-white solid by flash chromatography using $10 \%$ EtOAc in hexanes $(2.35 \mathrm{~g}, 80 \%$ over 2 steps $) . \mathrm{R}_{\mathrm{f}}=0.19$ (10\% EtOAc in hexanes). mp 72-73 ${ }^{\circ} \mathrm{C}$. IR (neat, $\mathrm{cm}^{-1}$ ): 3464, 3382, 1621, 1494, 1434, 1300, 1168, 1114. ${ }^{1} \mathrm{H}$ NMR $\left(400 \mathrm{MHz}, \mathrm{CDCl}_{3}\right) \delta$ 7.26-7.22 (2H, m), $6.48(1 \mathrm{H}, \mathrm{ddd}, J=8.5,8.5,2.6 \mathrm{~Hz}), 6.40(1 \mathrm{H}$, $\mathrm{dd}, J=10.4,2.6 \mathrm{~Hz}), 3.81(2 \mathrm{H}, \mathrm{br}) .{ }^{13} \mathrm{C} \mathrm{NMR}\left(100 \mathrm{MHz}, \mathrm{CDCl}_{3}\right) \delta 163.8\left(J_{\mathrm{C}-\mathrm{F}}=244\right.$ $\mathrm{Hz}), 145.6\left(J_{\mathrm{C}-\mathrm{F}}=11.4 \mathrm{~Hz}\right), 133.3,131.0\left(J_{\mathrm{C}-\mathrm{F}}=9.9 \mathrm{~Hz}\right), 117.8\left(J_{\mathrm{C}-\mathrm{F}}=2.3 \mathrm{~Hz}\right), 105.6\left(J_{\mathrm{C}-\mathrm{F}}\right.$ $=22.0 \mathrm{~Hz}), 102.5\left(J_{\mathrm{C}-\mathrm{F}}=25.1 \mathrm{~Hz}\right), 93.5\left(J_{\mathrm{C}-\mathrm{F}}=2.2\right) .{ }^{19} \mathrm{~F}$ NMR $\left(282 \mathrm{MHz}, \mathrm{CDCl}_{3}\right) \delta-$ 111.7. Anal. Calc'd for $\mathrm{C}_{8} \mathrm{H}_{6} \mathrm{Br}_{2} \mathrm{NF}$ : C, 32.58; H, 2.05; N, 4.75. Found: C, 32.86; H, 2.20; N, 4.78.

\section{2-(2,2-Dibromovinyl)-5-trifluoromethylphenylamine (1k)}<smiles>C=CC=CCCCCC(F)(F)F</smiles>

The general procedure was followed using 2-nitro-4-trifluoromethylbenzaldehyde (11.6 mmol scale). The product was obtained as an oil by flash chromatography using $10 \%$ EtOAc in hexanes $(3.10 \mathrm{~g}, 78 \%$ over 2 steps $) . \mathrm{R}_{\mathrm{f}}=0.27$ (10\% EtOAc in hexanes). IR (neat, $\mathrm{cm}^{-1}$ ): 3486, 3397, 1627, 1436, 1338, 1252, 1168, 1124. ${ }^{1} \mathrm{H}$ NMR (300 MHz, $\left.\mathrm{CDCl}_{3}\right) \delta 7.37(1 \mathrm{H}, \mathrm{d}, J=8.1 \mathrm{~Hz}), 7.31(1 \mathrm{H}, \mathrm{s}), 7.00(1 \mathrm{H}, \mathrm{d}, J=8.1 \mathrm{~Hz}), 6.93(1 \mathrm{H}, \mathrm{s})$, $3.88(2 \mathrm{H}, \mathrm{br}) .{ }^{13} \mathrm{C} \mathrm{NMR}\left(100 \mathrm{MHz}, \mathrm{CDCl}_{3}\right) \delta 144.1,133.1,131.8\left(\mathrm{q}, J_{\mathrm{C}-\mathrm{F}}=32.2 \mathrm{~Hz}\right)$, 130.0, $124.8\left(\mathrm{q}, J_{\mathrm{C}-\mathrm{F}}=1.3 \mathrm{~Hz}\right), 124.1\left(\mathrm{q}, J_{\mathrm{C}-\mathrm{F}}=271 \mathrm{~Hz}\right), 115.0\left(\mathrm{q}, J_{\mathrm{C}-\mathrm{F}}=3.8 \mathrm{~Hz}\right), 112.4$ $\left(J_{\mathrm{C}-\mathrm{F}}=3.9 \mathrm{~Hz}\right), 94.9\left(\mathrm{q}, J_{\mathrm{C}-\mathrm{F}}=0.8 \mathrm{~Hz}\right) .{ }^{19} \mathrm{~F} \mathrm{NMR}\left(282 \mathrm{MHz}, \mathrm{CDCl}_{3}\right) \delta-63.0 . \mathrm{HRMS}$ (ESI) calc'd for $\mathrm{C}_{9} \mathrm{H}_{7} \mathrm{NF}_{3} \mathrm{Br}_{2}\left([\mathrm{M}+\mathrm{H}]^{+}\right)$343.8891. Found: 343.8907 .

\section{3-Amino-4-(2,2-dibromovinyl)-benzoic acid methyl ester (11)}<smiles>COC(=O)c1ccc(C=O)c([N+](=O)[O-])c1</smiles>

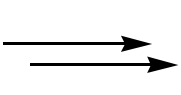<smiles>COC(=O)c1ccc(C=C(Br)Br)c(N)c1</smiles> 
The general procedure was followed using methyl 4-formyl-3-nitrobenzoate (5 mmol scale). The product was obtained as a yellow solid by flash chromatography using $10 \%$ EtOAc in hexanes (1.06 g, 63\% over 2 steps). $\mathrm{R}_{\mathrm{f}}=0.20$ (20\% EtOAc in hexanes). mp 97$99{ }^{\circ} \mathrm{C}$. IR (neat, $\mathrm{cm}^{-1}$ ): 3469, 3378, 1710, 1631, 1567, 1501, 1433, 1315, 1246, 1111. ${ }^{1} \mathrm{H}$ NMR $\left(300 \mathrm{MHz}, \mathrm{CDCl}_{3}\right) \delta$ 7.45-7.30 (4H, m), 3.90-3.85 (5H, m). ${ }^{13} \mathrm{C}$ NMR $(75 \mathrm{MHz}$, $\left.\mathrm{CDCl}_{3}\right) \delta 167.0,143.9,133.5,131.3,129.5,126.0,119.5,116.9,94.4,52.4$. HRMS (ESI) calc'd for $\mathrm{C}_{10} \mathrm{H}_{10} \mathrm{NO}_{2} \mathrm{Br}_{2}\left([\mathrm{M}+\mathrm{H}]^{+}\right)$333.9072. Found: 333.9089 .

\section{2-(2,2-Dibromovinyl)-6-methylphenylamine (1m)}

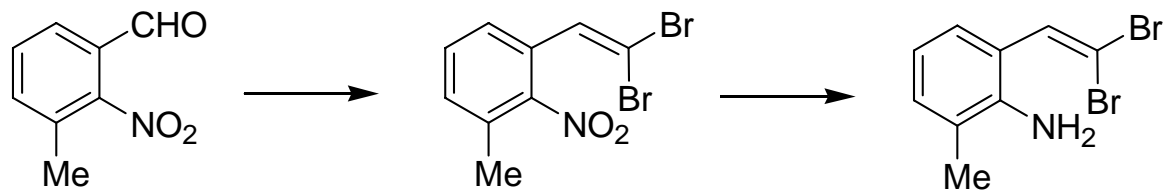

To a solution of 3-methyl-2-nitrobenzaldehyde (1.40 g, $8.5 \mathrm{mmol})$ and $\mathrm{CBr}_{4}(4.22 \mathrm{~g}, 12.7$ $\mathrm{mmol})$ in $\mathrm{DCM}(40 \mathrm{~mL})$ at $0{ }^{\circ} \mathrm{C}$ was added dropwise a solution of $\mathrm{PPh}_{3}(6.67 \mathrm{~g}, 25.44$ $\mathrm{mmol})$ ) in DCM $(40 \mathrm{~mL})$ by an addition funnel. The addition rate was controlled so that the internal temperature was at $1-5^{\circ} \mathrm{C}$. After addition, the mixture was stirred for another $1 \mathrm{~h}$ before warmed to $\mathrm{rt}$, and stirred for an additional $1 \mathrm{~h}$. To the reaction mixture was added hexane $(70 \mathrm{~mL})$, and filtered through a short plug of silica gel, washed with a copious amount of DCM until no product was found. The filtrate was collected, and solvent was removed under vacuum. The residue was chromatographed with 5\% EtOAc in hexane to afford 1-(2,2-dibromovinyl)-3-methyl-2-nitrobenzene as a slightly yellow solid (2.30 g, 85\%). $\mathrm{R}_{\mathrm{f}}=0.35$ (5\% EtOAc in hexanes). IR (neat, $\left.\mathrm{cm}^{-1}\right): 3028,1609,1527$, 1364. ${ }^{1} \mathrm{H}$ NMR (400 MHz, $\left.\mathrm{CDCl}_{3}\right) \delta$ 7.48-7.40 (3H, m), $7.31(1 \mathrm{H}, \mathrm{d}, J=7.3 \mathrm{~Hz}), 2.38$ $(3 \mathrm{H}, \mathrm{s}) .{ }^{13} \mathrm{C} \mathrm{NMR}\left(100 \mathrm{MHz}, \mathrm{CDCl}_{3}\right) \delta 149.8,131.9,131.6,130.8,130.6,128.9,128.0$, 95.6, 18.0. HRMS (EI) calc'd for $\mathrm{C}_{9} \mathrm{H}_{7} \mathrm{NO}_{2} \mathrm{Br}_{2}\left([\mathrm{M}]^{+}\right)$318.8844. Found: 318.8850 .

To a warm solution of 1-(2,2-dibromovinyl)-3-methyl-2-nitrobenzene (0.321 g, $1 \mathrm{mmol})$ in HOAc $(0.3 \mathrm{~mL})$ and EtOH $(2 \mathrm{~mL})$ was added iron powder $(0.405 \mathrm{~g}, 7 \mathrm{mmol})$ and $\mathrm{FeCl}_{3} \cdot 6 \mathrm{H}_{2} \mathrm{O}(36 \mathrm{mg})$. The mixture was heated at $100{ }^{\circ} \mathrm{C}$ for $2.5 \mathrm{~h}$ until the starting material was completely consumed. The mixture as filtered through a celite pad and 
washed with a copious amount of EtOAc. The solvent was removed and the residue was chromatographed with $10 \%$ EtOAc/hexanes to afford the product as an oil $(0.277 \mathrm{~g}$, 95\%). ${ }^{1} \mathrm{H}$ NMR $\left(400 \mathrm{MHz}, \mathrm{CDCl}_{3}\right) \delta 7.33(1 \mathrm{H}, \mathrm{s}), 7.15(1 \mathrm{H}, \mathrm{d}, J=7.7 \mathrm{~Hz}), 7.06(1 \mathrm{H}, \mathrm{d}, J$ $=7.3 \mathrm{~Hz}), 6.71(1 \mathrm{H}, \mathrm{t}, J=7.6 \mathrm{~Hz}), 3.66(2 \mathrm{H}, \mathrm{s}, \mathrm{br}), 2.10(3 \mathrm{H}, \mathrm{s}) .{ }^{13} \mathrm{C} \mathrm{NMR}(100 \mathrm{MHz}$, $\left.\mathrm{CDCl}_{3}\right) \delta 142.0,134.7,131.0,127.3,122.7,121.6,118.1,93.1,17.8$. HRMS (EI) calc'd for $\mathrm{C}_{9} \mathrm{H}_{9} \mathrm{NBr}_{2}\left([\mathrm{M}]^{+}\right)$288.9102. Found: 288.9087.

\section{2-(2,2-Dibromovinyl)-naphthalen-1-ylamine (1n)}

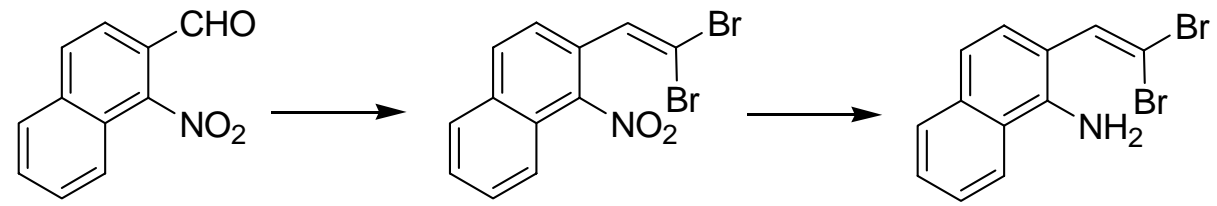

To a solution of 1-nitro-naphthalene-2-carboxaldehyde (3.77 g, $18.7 \mathrm{mmol})$ and $\mathrm{CBr}_{4}$ $(9.31 \mathrm{~g}, 28.1 \mathrm{mmol})$ in DCM $(100 \mathrm{~mL})$ at $0{ }^{\circ} \mathrm{C}$ was added dropwise a solution of $\mathrm{PPh}_{3}$ $(14.7 \mathrm{~g}, 56.1 \mathrm{mmol}))$ in DCM $(90 \mathrm{~mL})$ by an addition funnel. The addition rate was controlled so that the internal temperature was at $1-5^{\circ} \mathrm{C}$. After addition, the mixture was stirred for another $1 \mathrm{~h}$ before warmed to $\mathrm{rt}$, and stirred for an additional $0.5 \mathrm{~h}$. To the reaction mixture was added hexane $(70 \mathrm{~mL})$, and filtered through a short plug of silica gel and the silica gel was washed with a copious amount of $10 \%$ EtOAc/hexanes until no product was found. The filtrate was collected, and solvent was removed under vacuum. The residue was chromatographed with $10 \%$ EtOAc in hexane to afford the product 2(2,2-dibromovinyl)-1-nitronaphthalene as an off-white solid (5.50 g, 82\%). ${ }^{1} \mathrm{H}$ NMR (400 $\left.\mathrm{MHz}, \mathrm{CDCl}_{3}\right) \delta 8.00(1 \mathrm{H}, \mathrm{d}, J=8.8 \mathrm{~Hz}), 7.93-7.90(1 \mathrm{H}, \mathrm{m}), 7.85-7.82(1 \mathrm{H}, \mathrm{m}), 7.69(1 \mathrm{H}$, d, $J=8.6 \mathrm{~Hz}), 7.68-7.63(2 \mathrm{H}, \mathrm{m}), 7.62(1 \mathrm{H}, \mathrm{s}) .{ }^{13} \mathrm{C} \mathrm{NMR}\left(100 \mathrm{MHz}, \mathrm{CDCl}_{3}\right) \delta 146.6$, 133.7, 131.6, 131.2, 129.3, 128.4, 128.3, 126.4, 125.7, 124.5, 122.3, 96.3. HRMS calc'd for $\mathrm{C}_{12} \mathrm{H}_{7} \mathrm{NO}_{2} \mathrm{Br}_{2}\left([\mathrm{M}]^{+}\right)$354.8843. Found: 354.8840 .

To a warm solution of 2-(2,2-dibromovinyl)-1-nitronaphthalene $(2.53 \mathrm{~g}, 7.09 \mathrm{mmol})$ in HOAc $(2.5 \mathrm{~mL})$ and EtOH $(15 \mathrm{~mL})$ was added iron powder $(2.84 \mathrm{~g}, 50 \mathrm{mmol})$ and $\mathrm{FeCl}_{3} \cdot 6 \mathrm{H}_{2} \mathrm{O}(0.252 \mathrm{~g})$. The mixture was stirred and heated to $100{ }^{\circ} \mathrm{C}$ for $1 \mathrm{~h}$ until the starting material was completely consumed. The mixture was filtered through a celite pad 
and washed with a copious amount of EtOAc. The solvent was removed, and the residue was chromatographed with $7.5 \%$ EtOAc/hexanes to afford the product as a yellow solid (2.035 g, 88\%). ${ }^{1} \mathrm{H}$ NMR (400 MHz, $\left.\mathrm{CDCl}_{3}\right) \delta$ 7.82-7.76 (2H, m), $7.51(1 \mathrm{H}, \mathrm{s}), 7.50-7.43$ $(2 \mathrm{H}, \mathrm{m}), 7.38(1 \mathrm{H}, \mathrm{d}, J=8.6 \mathrm{~Hz}), 7.28(1 \mathrm{H}, \mathrm{d}, J=8.6 \mathrm{~Hz}), 4.27(2 \mathrm{H}, \mathrm{br}) .{ }^{13} \mathrm{C}$ NMR $(100$ $\left.\mathrm{MHz}, \mathrm{CDCl}_{3}\right) \delta 139.4,134.8,134.3,128.9,126.7,126.6,125.6,123.5,121.0,118.4$, 116.1, 76.8. HRMS calc'd for $\mathrm{C}_{12} \mathrm{H}_{9} \mathrm{NBr}_{2}\left([\mathrm{M}]^{+}\right)$324.9102. Found: 324.9089 .

\section{2-(2,2-Dibromo-1-trifluoromethylvinyl)-phenylamine (4a)}

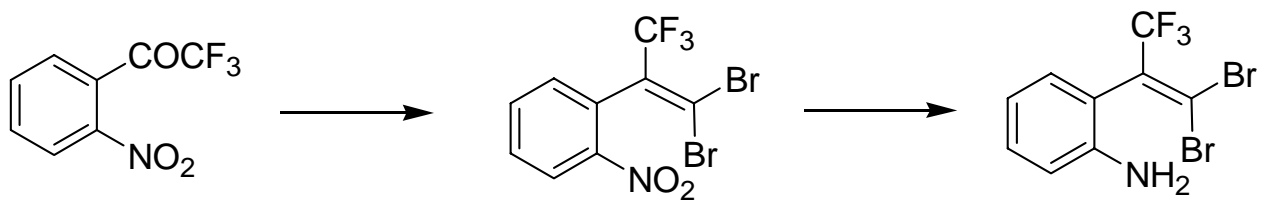

To a solution of 2'-nitro-1,1,1-trifluoroacetophenone (1.88 g, $8.58 \mathrm{mmol})$ and $\mathrm{CBr}_{4}$ in DCM $(45 \mathrm{~mL})$ was added dropwise a solution of $\mathrm{PPh}_{3}$ solution in DCM $(45 \mathrm{~mL})$ at $0{ }^{\circ} \mathrm{C}$. The mixture was stirred for another $1 \mathrm{~h}$, warmed to rt, and stirred for an additional $0.5 \mathrm{~h}$. The mixture was precipitated by addition of $\mathrm{Et}_{2} \mathrm{O}(20 \mathrm{~mL})$ and hexanes $(50 \mathrm{~mL})$, filtered through a short plug of silica gel. The crude material was further purified by flash chromatography (10\% EtOAc in hexanes) to afford the product as a slightly yellow solid

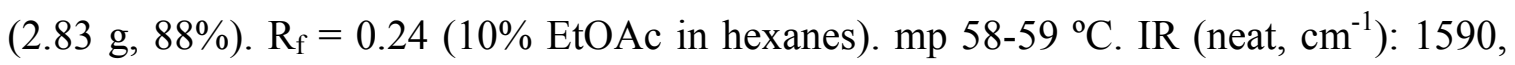
$1532,1347,1297,1197,1182,1138 .{ }^{1} \mathrm{H}$ NMR $\left(400 \mathrm{MHz}, \mathrm{CDCl}_{3}\right) \delta 8.26(1 \mathrm{H}, \mathrm{dd}, J=$ 8.1, $1.3 \mathrm{~Hz}), 7.76(1 \mathrm{H}, \mathrm{ddd}, J=7.6,7.6,1.3 \mathrm{~Hz}), 7.67(1 \mathrm{H}, \mathrm{ddd}, J=7.9,7.9,1.5 \mathrm{~Hz})$, $7.40(1 \mathrm{H}, \mathrm{dd}, J=7.6,1.4 \mathrm{~Hz}) .{ }^{13} \mathrm{C}$ NMR $\left(100 \mathrm{MHz}, \mathrm{CDCl}_{3}\right) \delta 147.0,135.8\left(\mathrm{q}, J_{\mathrm{CF}}=33.7\right.$ $\mathrm{Hz}), 134.6,131.6,131.2,130.9,125.5,121.6\left(\mathrm{q}, J_{\mathrm{CF}}=276 \mathrm{~Hz}\right), 101.0\left(\mathrm{q}, J_{\mathrm{CF}}=3.1 \mathrm{~Hz}\right)$. ${ }^{19} \mathrm{~F}$ NMR $\left(376 \mathrm{MHz}, \mathrm{CDCl}_{3}\right) \delta-59.2$.

A mixture of 1-(2,2-dibromo-1-trifluoromethylvinyl)-2-nitrobenzene (1.875 g, 5 $\mathrm{mmol})$ and $\mathrm{SnCl}_{2} \cdot 2 \mathrm{H}_{2} \mathrm{O}(5.64 \mathrm{~g}, 25 \mathrm{mmol})$ in $\mathrm{EtOH}(30 \mathrm{~mL})$ was heated to reflux for $8 \mathrm{~h}$. The mixture was taken into EtOAc $(50 \mathrm{~mL})$ and neutralized with $\mathrm{K}_{2} \mathrm{CO}_{3}$. After extraction with $\mathrm{Et}_{2} \mathrm{O}(3 \times 30 \mathrm{~mL})$, the organic phase was dried over $\mathrm{Na}_{2} \mathrm{SO}_{4}$. After removal of solvent, the crude material was purified by flash chromatography $(10 \%$ EtOAc in hexanes) to afford the product $(1.54 \mathrm{~g}, 89 \%)$ as an oil (solidified in freezer). $R_{\mathrm{f}}=0.25$ 
(10\% EtOAc in hexanes). $\mathrm{mp} 25-26^{\circ} \mathrm{C}$. IR (neat, $\left.\mathrm{cm}^{-1}\right): 3481,3393,3029,1621,1578$, $1493,1454,1292,1199,1176,1130 .{ }^{1} \mathrm{H}$ NMR $\left(400 \mathrm{MHz}, \mathrm{CDCl}_{3}\right) \delta 7.22(1 \mathrm{H}, \mathrm{ddd}, J=$ 7.8, 7.8, 1.4 Hz), $6.97(1 \mathrm{H}, \mathrm{dd}, J=7.7,1.3 \mathrm{~Hz}), 6.80(1 \mathrm{H}$, ddd, $J=7.6,7.6,0.9 \mathrm{~Hz}), 7.56$ $(1 \mathrm{H}, \mathrm{d}, J=8.1 \mathrm{~Hz}), 3.71(2 \mathrm{H}, \mathrm{br}) .{ }^{13} \mathrm{C}$ NMR $\left(100 \mathrm{MHz}, \mathrm{CDCl}_{3}\right) \delta 143.9,135.6\left(\mathrm{q}, J_{\mathrm{C}-\mathrm{F}}=\right.$ $33.2 \mathrm{~Hz}), 131.0,129.6,122.3\left(\mathrm{q}, J_{\mathrm{C}-\mathrm{F}}=277 \mathrm{~Hz}\right), 121.1,118.9,116.3,103.8\left(\mathrm{q}, J_{\mathrm{C}-\mathrm{F}}=2.8\right.$ $\mathrm{Hz}) .{ }^{19} \mathrm{~F}$ NMR $\left(376 \mathrm{MHz}, \mathrm{CDCl}_{3}\right) \delta$-58.8. HRMS calc'd for $\mathrm{C}_{9} \mathrm{H}_{6} \mathrm{NF}_{3} \mathrm{Br}_{2}\left([\mathrm{M}]^{+}\right)$ 342.8819. Found: 342.8830 .

\section{2-(1-Dibromomethylene-3-phenylprop-2-ynyl)phenylamine (4b)}
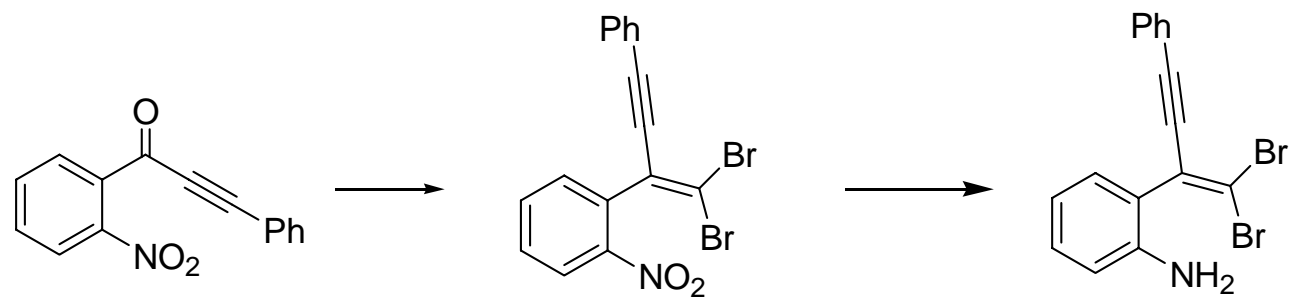

To a solution of 1-(2-nitrophenyl)-3-phenylpropynone (1.41 g, $5.6 \mathrm{mmol})$ and $\mathrm{CBr}_{4}$ $(2.78 \mathrm{~g}, 8.4 \mathrm{mmol})$ in $\mathrm{DCM}(50 \mathrm{~mL})$ at $0{ }^{\circ} \mathrm{C}$ was added dropwise a solution of $\mathrm{PPh}_{3}(4.41$ $\mathrm{g}, 16.8 \mathrm{mmol})$ in DCM $(50 \mathrm{~mL})$ by an addition funnel. The addition rate was controlled so that the internal temperature was at $1-5^{\circ} \mathrm{C}$. After addition, the mixture was stirred for another $1 \mathrm{~h}$. To the reaction mixture was added hexane $(70 \mathrm{~mL})$ and filtered through a short plug of silica gel, washed with a copious amount of $10 \%$ EtOAc/hexanes until no product was found. The filtrate was collected, and solvent was removed under vacuum. The residue was chromatographed with $10 \%$ EtOAc in hexanes to afford the product 1(1-dibromomethylene-3-phenylprop-2-ynyl)-2-nitrobenzene as a white solid (1.23 g, 54\%). mp 64-66 ${ }^{\circ} \mathrm{C}$. IR (neat, $\mathrm{cm}^{-1}$ ): 3064, 2210, 1608, 1574, 1526, 1348. ${ }^{1} \mathrm{H}$ NMR (400 $\left.\mathrm{MHz}, \mathrm{CDCl}_{3}\right) \delta 8.12(1 \mathrm{H}, \mathrm{dd}, J=8.4,1.1 \mathrm{~Hz}), 7.69(1 \mathrm{H}, \mathrm{ddd}, J=7.6,7.6,1.1 \mathrm{~Hz}), 7.57$ $(1 \mathrm{H}$, ddd, $J=8.3,7.3,1.5 \mathrm{~Hz}), 7.50(1 \mathrm{H}, \mathrm{dd}, J=7.7,1.3 \mathrm{~Hz}), 7.45-7.43(2 \mathrm{H}, \mathrm{m}), 7.36-$ $7.28(3 \mathrm{H}, \mathrm{m}) .{ }^{13} \mathrm{C} \mathrm{NMR}\left(100 \mathrm{MHz}, \mathrm{CDCl}_{3}\right) \delta 147.1,133.7,133.4,131.6,131.2,129.8$, 129.2, 128.4, 127.6, 125.0, 122.1, 100.7, 98.0, 86.8. HRMS calc'd for $\mathrm{C}_{16} \mathrm{H}_{9} \mathrm{NO}_{2} \mathrm{Br}_{2}$ $\left([\mathrm{M}]^{+}\right)$404.9000. Found: 404.9002. 
A mixture of 1-(1-dibromomethylene-3-phenylprop-2-ynyl)-2-nitrobenzene (1.018 g, $2.5 \mathrm{mml})$ and $1 \% \mathrm{Pt}-\mathrm{C}[\mathrm{V}](120 \mathrm{mg})$ in $\mathrm{MeOH}(10 \mathrm{~mL})$ was hydrogenated under $1 \mathrm{~atm}$ $\mathrm{H}_{2}$ (balloon) for 7 hours until all the starting material was consumed. The catalyst was removed by filtration, and the solvent was removed under vacuum. The resulting residue was chromatographed with 5\% EtOAc in hexanes to afford the product as an oil $(0.838 \mathrm{~g}$, $89 \%) . \mathrm{R}_{\mathrm{f}}=0.15$ (5\% EtOAc/hexanes). ${ }^{1} \mathrm{H}$ NMR $\left(400 \mathrm{MHz}, \mathrm{CDCl}_{3}\right) \delta$ 7.47-7.45 (2H, m), 7.36-7.26 (3H, m), $7.17(1 \mathrm{H}$, ddd, $J=7.7,7.7,1.3 \mathrm{~Hz}), 7.13(1 \mathrm{H}, \mathrm{dd}, J=7.6,1.2 \mathrm{~Hz})$, $6.78(1 \mathrm{H}, \mathrm{t}, J=7.6 \mathrm{~Hz}), 6.72(1 \mathrm{H}, \mathrm{d}, J=8.1 \mathrm{~Hz}), 3.87(2 \mathrm{H}, \mathrm{br}) .{ }^{13} \mathrm{C} \mathrm{NMR}(100 \mathrm{MHz}$, $\left.\mathrm{CDCl}_{3}\right) \delta 143.4,131.8,130.1,129.7,129.2,128.6,123.7,122.5,118.6,116.3,102.1$, 97.9, 87.6. HRMS (ESI) calc'd for $\mathrm{C}_{16} \mathrm{H}_{12} \mathrm{NBr}_{2}\left([\mathrm{M}+\mathrm{H}]^{+}\right)$375.9330. Found: 375.9330 .

\section{1-(4-Fluorophenyl)-1-(2-nitrophenyl)ethane (7)}

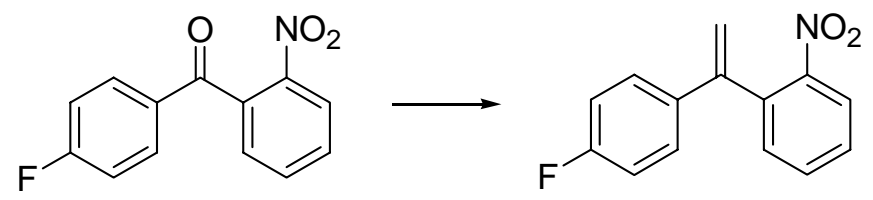

To a suspension of methyltriphenylphosphonium bromide $(11.2 \mathrm{~g}, 31 \mathrm{mmol}$, predried at $100{ }^{\circ} \mathrm{C}$ at $0.2 \mathrm{~mm} \mathrm{Hg}$ for $\left.1 \mathrm{~h}\right)$ in THF $(50 \mathrm{~mL})$ was added dropwise $n$-BuLi (19.5 $\mathrm{mL}, 1.6 \mathrm{M}$ in hexane, $31 \mathrm{mmol}$ ) at $0{ }^{\circ} \mathrm{C}$. After addition, the red/orange solution was stirred at $0{ }^{\circ} \mathrm{C}$ for an additional $0.5 \mathrm{~h}$. To this Wittig reagent was added dropwise a solution of 4-fluoro-2'-nitrobenzophenone (6.13 g, $25 \mathrm{mmol})$ in THF $(40 \mathrm{~mL})$. The reaction was stirred at $0{ }^{\circ} \mathrm{C}$ for another $2 \mathrm{~h}$ before it was quenched by $\mathrm{NH}_{4} \mathrm{Cl}$ (saturated, $30 \mathrm{~mL})$. The mixture was extracted wit EtOAc $(3 \times 50 \mathrm{~mL})$, washed with brine, dried over $\mathrm{MgSO}_{4}$. After removal of solvent the residue was purified by flash chromatograph using $10 \%$ EtOAc in hexanes to afford a slightly yellow solid $(5.32 \mathrm{~g}, 87.5 \%) . \mathrm{R}_{\mathrm{f}}=0.25$ (10\% EtOAc in hexanes). mp 45-46 ${ }^{\circ} \mathrm{C}$. IR (neat, $\mathrm{cm}^{-1}$ ): 3070, 1604, 1528, 1351, 1229, 1160. ${ }^{1} \mathrm{H}$ NMR $\left(400 \mathrm{MHz}, \mathrm{CDCl}_{3}\right) \delta 7.94(1 \mathrm{H}, \mathrm{dd}, J=8.1,1.1 \mathrm{~Hz}), 7.64(1 \mathrm{H}, \mathrm{ddd}, J=$ 7.6, 7.6, 1.3 Hz), 7.51 (1H, ddd, $J=7.8,7.8,1.3 \mathrm{~Hz}), 7.45(1 \mathrm{H}, \mathrm{dd}, J=7.6,1.4 \mathrm{~Hz}), 7.23-$ $7.19(2 \mathrm{H}, \mathrm{m}), 7.00-6.95(2 \mathrm{H}, \mathrm{m}), 5.68(1 \mathrm{H}, \mathrm{s}), 5.29(1 \mathrm{H}, \mathrm{s}) .{ }^{13} \mathrm{C} \mathrm{NMR}\left(100 \mathrm{MHz}, \mathrm{CDCl}_{3}\right)$ $\delta 162.8\left(J_{\mathrm{C}-\mathrm{F}}=248 \mathrm{~Hz}\right), 149.0,145.7,136.9,135.5\left(J_{\mathrm{C}-\mathrm{F}}=3.8 \mathrm{~Hz}\right), 133.1,132.5,129.0$, $128.5\left(J_{\mathrm{C}-\mathrm{F}}=7.7 \mathrm{~Hz}\right), 124.6,115.6,115.5\left(J_{\mathrm{C}-\mathrm{F}}=21.5 \mathrm{~Hz}\right) .{ }^{19} \mathrm{~F} \mathrm{NMR}\left(376 \mathrm{MHz}, \mathrm{CDCl}_{3}\right) \delta$ 
-113.8. HRMS (EI) calc'd for $\mathrm{C}_{14} \mathrm{H}_{10} \mathrm{NO}_{2} \mathrm{~F}$ ([M] $\left.{ }^{+}\right)$243.0696. Found: 243.0692. Anal. Calc'd for $\mathrm{C}_{14} \mathrm{H}_{10} \mathrm{NO}_{2} \mathrm{~F}$ : C, 69.13; H, 4.14; N, 5.76. Found: C, 69.24; H, 4.21; N, 5.72.

\section{2,2-Dibromo-1-(4-fluorophenyl)-1-(2-nitrophenyl)ethene (9)}

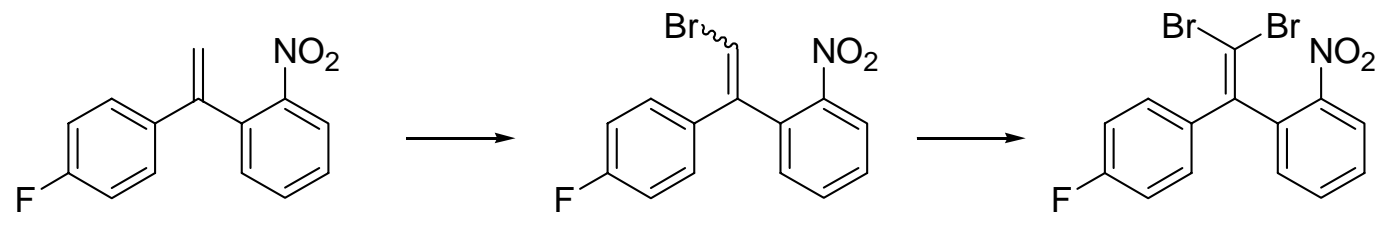

To a solution of 1-(4-fluorophenyl)-1-(2-nitrophenyl)ethene $(5.03 \mathrm{~g}, 20.7 \mathrm{mml})$ in DCM $(30 \mathrm{~mL})$ was added dropwise a $\mathrm{Br}_{2}$ solution $(3.5 \mathrm{~g})$ in DCM $(5 \mathrm{~mL})$ at $0{ }^{\circ} \mathrm{C}$. The mixture was stirred for another $2 \mathrm{~h}$, and warmed to rt. Solvent was removed under vacuum to give the intermediate as a solid. The solid was dissolved in benzene $(30 \mathrm{~mL})$ followed by pyridine $\left(8 \mathrm{~mL}\right.$ ). The mixture was heated at $100{ }^{\circ} \mathrm{C}$ (reflux) for $3 \mathrm{~h}$, cooled to rt, diluted with EtOAc $(40 \mathrm{~mL})$, washed with $\mathrm{HCl}(1 \mathrm{M}, 2 \times 25 \mathrm{~mL}), \mathrm{NaHCO}_{3}$ (saturated, $25 \mathrm{~mL}$ ), brine $(25 \mathrm{~mL})$, and dried over $\mathrm{MgSO}_{4}$. The solvent was removed under vacuum to give a red-colored crude intermediate, which contains a $\mathrm{Z} / \mathrm{E}$ mixture of monobrominated alkene $(6.66 \mathrm{~g}, 100 \%)$. The intermediate was taken into acetic acid (60 $\mathrm{mL}$ ) and $\mathrm{Br}_{2}$ added $\left(5.5 \mathrm{~g}\right.$ ). The mixture was heated at $115^{\circ} \mathrm{C}$ (reflux) for $5 \mathrm{~h}$ and cooled to rt. Excess $\mathrm{Br}_{2}$ and solvent were removed under vacuum. The residue was taken into $\mathrm{NaHCO}_{3}$ (saturated, $50 \mathrm{~mL}$ ), extracted with $\mathrm{Et}_{2} \mathrm{O}(2 \times 50 \mathrm{~mL})$, washed with $\mathrm{NaHCO}_{3}$ (saturated, $25 \mathrm{~mL}$ ), brine $\left(25 \mathrm{~mL}\right.$ ), and dried over $\mathrm{MgSO}_{4}$. The crude material was purified by flash chromatography using $10 \%$ EtOAc in hexanes to afford the desired product as a slight-tan solid ( $8.0 \mathrm{~g}, 96 \%) . \mathrm{R}_{\mathrm{f}}=0.21$ (7.5\% EtOAc in hexanes). mp 99-100 ${ }^{\circ} \mathrm{C}$. IR (neat, $\mathrm{cm}^{-1}$ ): 3071, 1603, 1527, 1505, 1348, 1232, 1160. ${ }^{1} \mathrm{H}$ NMR (400 MHz, $\left.\mathrm{CDCl}_{3}\right) \delta 8.09(1 \mathrm{H}, \mathrm{dd}, J=8.2,1.2 \mathrm{~Hz}), 7.69(1 \mathrm{H}, \mathrm{ddd}, J=7.6,7.6,1.3 \mathrm{~Hz}), 7.53(1 \mathrm{H}$, ddd, $J=8.0,7.7,1.4 \mathrm{~Hz}$ ), $7.48(1 \mathrm{H}, \mathrm{dd}, J=7.7,1.3 \mathrm{~Hz}), 7.44-7.40$ (2H, m), 7.04-6.98 $(2 \mathrm{H}, \mathrm{m}) .{ }^{13} \mathrm{C}$ NMR $\left(100 \mathrm{MHz}, \mathrm{CDCl}_{3}\right) \delta 162.7\left(J_{\mathrm{C}-\mathrm{F}}=249 \mathrm{~Hz}\right), 147.1,143.0,136.8,134.6$ $\left(J_{\mathrm{C}-\mathrm{F}}=3.1 \mathrm{~Hz}\right), 134.0,131.5,131.4\left(J_{\mathrm{C}-\mathrm{F}}=8.5 \mathrm{~Hz}\right), 129.6,125.5,115.6\left(J_{\mathrm{C}-\mathrm{F}}=22.2 \mathrm{~Hz}\right)$, 92.4. ${ }^{19} \mathrm{~F}$ NMR (376 MHz, $\mathrm{CDCl}_{3}$ ) $\delta$-111.9. HRMS (ESI) calc'd for $\mathrm{C}_{14} \mathrm{H}_{9} \mathrm{NO}_{2} \mathrm{FBr}_{2}$ $\left([\mathrm{M}+\mathrm{H}]^{+}\right)$399.8984. Found: 399.8984. Anal. Calc'd for $\mathrm{C}_{14} \mathrm{H}_{8} \mathrm{NO}_{2} \mathrm{FBr}_{2}$ : C, 41.93; $\mathrm{H}$, $2.01 ; \mathrm{N}, 3.49$. Found: C, 42.09; H, 2.01; N, 3.46 . 


\section{2,2-dibromo-1-(4-fluorophenyl)-1-(2-aminophenyl)ethene (10)}<smiles>O=[N+]([O-])c1ccccc1C(=C(Br)Br)c1ccc(F)cc1</smiles><smiles>Nc1ccccc1C(=C(Br)Br)c1ccc(F)cc1</smiles>

Fe as the reducing agent: A mixture of $9(0.401 \mathrm{~g}, 1 \mathrm{mmol})$ and iron powder $(0.196 \mathrm{~g}$, $3.5 \mathrm{~mL}$ ) in acetic acid $(2 \mathrm{~mL})$ was heated to $115^{\circ} \mathrm{C}$ (reflux) for $2 \mathrm{~h}$. The mixture was diluted with EtOAc $(10 \mathrm{~mL})$, and filtered through a celite pad. The mixture was washed with $\mathrm{H}_{2} \mathrm{O}(2 \times 10 \mathrm{~mL}), \mathrm{NaHCO}_{3}$ (saturated, $\left.10 \mathrm{~mL}\right)$, brine $(5 \mathrm{~mL})$, and dried over $\mathrm{Na}_{2} \mathrm{SO}_{4}$. The crude material after removal of solvent was purified by flash chromatography using $10 \%$ EtOAc in hexanes to afford the product $\mathbf{1 0}$ as a solid $(0.260$ g, 70\%). $\mathrm{R}_{\mathrm{f}}=0.22\left(10 \%\right.$ EtOAc in hexanes). $\mathrm{mp} 88-89^{\circ} \mathrm{C}$. IR (neat, $\mathrm{cm}^{-1}$ ): 3466, 3380, 1614, 1502, 1449, 1301, 1228, 1158. ${ }^{1} \mathrm{H}$ NMR (400 MHz, $\left.\mathrm{CDCl}_{3}\right) \delta$ 7.44-7.38 (2H, m), $7.14(1 \mathrm{H}, \mathrm{ddd}, J=7.7,7.7,1.5 \mathrm{~Hz}), 7.04-6.98(3 \mathrm{H}, \mathrm{m}), 6.77(1 \mathrm{H}, \mathrm{ddd}, J=7.5,7.5,1.1$ $\mathrm{Hz}), 6.71(1 \mathrm{H}, \mathrm{dd}, J=8.1,0.9 \mathrm{~Hz}), 3.75(2 \mathrm{H}, \mathrm{s}, \mathrm{br}) .{ }^{13} \mathrm{C} \mathrm{NMR}\left(100 \mathrm{MHz}, \mathrm{CDCl}_{3}\right) \delta 162.5$ $\left(J_{\mathrm{C}-\mathrm{F}}=249 \mathrm{~Hz}\right), 144.5,142.8,135.7\left(J_{\mathrm{C}-\mathrm{F}}=3.8 \mathrm{~Hz}\right), 130.8\left(J_{\mathrm{C}-\mathrm{F}}=8.4 \mathrm{~Hz}\right), 129.7,129.5$, 127.9, 118.9, 116.5, $115.7\left(J_{\mathrm{C}-\mathrm{F}}=21.5 \mathrm{~Hz}\right), 92.4 .{ }^{19} \mathrm{~F}$ NMR $\left(376 \mathrm{MHz}, \mathrm{CDCl}_{3}\right) \delta-112.5$. HRMS (EI) calc'd for $\mathrm{C}_{14} \mathrm{H}_{10} \mathrm{NFBr}_{2}\left([\mathrm{M}]^{+}\right)$368.9164. Found: 368.9175.

$\mathbf{F e} / \mathrm{FeCl}_{3} \cdot \mathbf{6 H}_{2} \mathrm{O}$ as the reducing agent: To a warm solution of $\mathbf{9}(0.401 \mathrm{~g}, 1.0 \mathrm{mmol})$ in HOAc $(0.3 \mathrm{~mL})$ and EtOH $(2 \mathrm{~mL})$ was added iron powder $(0.405 \mathrm{~g}, 7 \mathrm{mmol})$ and $\mathrm{FeCl}_{3} \cdot 6 \mathrm{H}_{2} \mathrm{O}(30 \mathrm{mg})$. The mixture was heated at $100{ }^{\circ} \mathrm{C}$ for $2 \mathrm{~h}$ until the starting material was completely consumed. The mixture was filtered through a celite pad, and washed with a copious amount of EtOAc. Solvent was removed, and the residue was chromatographed using 10\% EtOAc/hexanes to afford the product $\mathbf{1 0}$ as a solid $(0.307 \mathrm{~g}$, $83 \%)$.

$\mathbf{H}_{2} / \mathbf{P t}-\mathbf{C}[\mathrm{V}]$ as the reducing agent: A mixture of $9(0.200 \mathrm{~g}, 0.5 \mathrm{mmol})$ and $1 \% \mathrm{Pt}-\mathrm{C}[\mathrm{V}]$ $(20 \mathrm{mg})$ in $\mathrm{MeOH}(2 \mathrm{~mL})$ was hydrogenated under 1 atm $\mathrm{H}_{2}$ (balloon) for 6 hours until all the starting material was consumed. The catalyst was removed by filtration, and the 
residue after removal of solvent was chromatographed with 10\% EtOAc/hexanes to afford the product $\mathbf{1 0}$ as a solid $(0.1735 \mathrm{~g}, 93 \%)$.

$\mathrm{SnCl}_{2} \cdot 2 \mathrm{H}_{2} \mathrm{O}$ as the reducing agent: A mixture of $9(0.700 \mathrm{~g}, 1.75 \mathrm{mmol})$ and $\mathrm{SnCl}_{2} \cdot 2 \mathrm{H}_{2} \mathrm{O}(1.97 \mathrm{~g}, 8.75 \mathrm{mmol})$ in $\mathrm{EtOH}(8 \mathrm{~mL})$ were heated to $100{ }^{\circ} \mathrm{C}$ for $10 \mathrm{~h}$. The mixture was cooled to rt, neutralized with $\mathrm{K}_{2} \mathrm{CO}_{3} / \mathrm{H}_{2} \mathrm{O}$, extracted with EtOAc $(4 \times 30$ $\mathrm{mL}$ ), washed with brine, and dried over $\mathrm{Na}_{2} \mathrm{SO}_{4}$. The residue after removal of solvent was chromatographed with $10 \%$ EtOAc/hexanes to afford 10 as a solid (0.258 g, 40\%).

\section{1-(2,2-Dichloro-1-methylvinyl)-2-nitrobenzene (12b)}

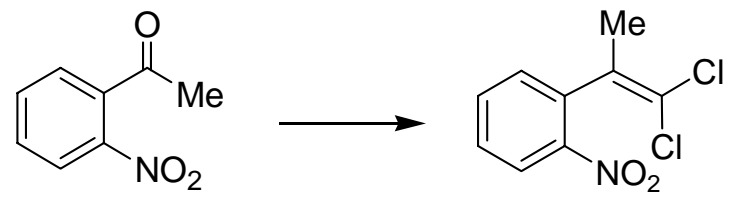

Preparation of $\mathrm{KOtBu} \cdot \mathrm{HOtBu}: \mathrm{A}$ mixture of $\mathrm{KOtBu}(56 \mathrm{~g})$, $\mathrm{HOtBu}(46 \mathrm{~g})$, and anhydrous $n$-heptane $(100 \mathrm{~mL})$ was heated to $115^{\circ} \mathrm{C}$ (reflux) for $1 \mathrm{~h}$. $n$-Heptane was distilled off at a bath temperature of $115^{\circ} \mathrm{C}$. The mixture was cooled to $\mathrm{rt}$, and the residual $\mathrm{HOtBu}$ was removed under vacuum $(0.3 \mathrm{~mm} \mathrm{Hg})$ for $1 \mathrm{~h}$ to yield a white powder (90.5 g, 97\%).

To the $\mathrm{KOtBu} \cdot \mathrm{HOtBu}(18.6 \mathrm{~g}, 0.1 \mathrm{~mol})$ was added n-heptane $(350 \mathrm{~mL})$, followed by $\mathrm{PPh}_{3}(26.2 \mathrm{~g}, 0.1 \mathrm{~mol})$ and the mixture was heated to $100{ }^{\circ} \mathrm{C}$ for $5 \mathrm{~min}$ and cooled to $<5$ ${ }^{\circ} \mathrm{C}$ with an ice bath. A chloroform $(11.9 \mathrm{~g}, 0.1 \mathrm{~mol}) \mathrm{n}$-heptane $(100 \mathrm{~mL})$ solution was added dropwise to the mixture. After the addition, the mixture was stirred for another 30 min and warmed to rt. The mixture was concentrated to about $150 \mathrm{~mL}$ using a rotary evaporator (high vacuum). To the mixture of the reagent was added a solution of 2'nitroacetophenone $(7.6 \mathrm{~g}, 0.046 \mathrm{~mol})$ in benzene $(100 \mathrm{~mL})$ under $10{ }^{\circ} \mathrm{C}$. After addition, the mixture was slowly warmed to rt overnight, and filtered through a celite pad. Solvent was removed and the residue was redissolved in $\mathrm{Et}_{2} \mathrm{O}(100 \mathrm{~mL}) . \mathrm{H}_{2} \mathrm{O}_{2}(10 \%, 10 \mathrm{~mL})$ was added to the mixture, and stirred for $0.5 \mathrm{~h}$. Hexanes $(200 \mathrm{~mL})$ were added, and the 
resulting triphenylphosphine oxide precipitate was removed by filtration. The organic phase was washed with $\mathrm{Na}_{2} \mathrm{SO}_{3}$ (saturated, $\left.20 \mathrm{~mL}\right), \mathrm{H}_{2} \mathrm{O}(50 \mathrm{~mL})$, brine $(20 \mathrm{~mL})$, and

dried over $\mathrm{MgSO}_{4}$. The crude material was further purified by flash chromatography with $10 \%$ EtOAc in hexanes to afford the desired product $(10.0 \mathrm{~g}, 94 \%)$ as a slightly yellow solid. ${ }^{1} \mathrm{H}$ NMR $\left(300 \mathrm{MHz}, \mathrm{CDCl}_{3}\right) \delta 8.10(1 \mathrm{H}, \mathrm{dd}, J=8.2,1.2 \mathrm{~Hz}), 7.66(1 \mathrm{H}, \mathrm{ddd}, J=$ 7.6, 7.6, 1.3 Hz), 7.51 (1H, ddd, $J=8.1,7.5,1.5 \mathrm{~Hz}), 7.30(1 \mathrm{H}, \mathrm{dd}, J=7.7,1.5 \mathrm{~Hz}), 2.22$ $(3 \mathrm{H}, \mathrm{s})$.

\section{2-(2,2-Dichloro-1-methylvinyl)-phenylamine (13b)}<smiles>CC(=C(Cl)Cl)c1ccccc1N</smiles>

$\mathrm{SnCl}_{2} \cdot 2 \mathrm{H}_{2} \mathrm{O}$ as the reducing agent: A mixture of $12 \mathrm{~b}(6.5 \mathrm{~g}, 28 \mathrm{mmol})$ and $\mathrm{SnCl}_{2} \cdot 2 \mathrm{H}_{2} \mathrm{O}(31.6 \mathrm{~g}, 140 \mathrm{mmol})$ in $\mathrm{EtOH}(100 \mathrm{~mL})$ was heated at $100{ }^{\circ} \mathrm{C}$ under reflux for $8 \mathrm{~h}$. Most of the EtOH was removed under vacuum, and the residue was diluted with EtOAc $(50 \mathrm{~mL})$. The mixture was neutralized by addition of $\mathrm{K}_{2} \mathrm{CO}_{3}$ and $\mathrm{H}_{2} \mathrm{O}$ until $\mathrm{pH}>$ 9. The resulting heterogeneous mixture was extracted with EtOAc $(4 \times 30 \mathrm{~mL})$, dried over $\mathrm{Na}_{2} \mathrm{SO}_{4}$. The crude material was further purified by flash chromatography with $10 \%$ EtOAc in hexanes to afford $\mathbf{1 3 b}$ as an oil $(5.3 \mathrm{~g}, 94 \%) .{ }^{1} \mathrm{H}$ NMR $\left(300 \mathrm{MHz}, \mathrm{CDCl}_{3}\right) \delta$ $7.13(1 \mathrm{H}, \mathrm{ddd}, J=7.9,7.3,1.6 \mathrm{~Hz}), 6.95(1 \mathrm{H}, \mathrm{dd}, J=7.6,1.5 \mathrm{~Hz}), 6.77(1 \mathrm{H}, \mathrm{ddd}, J=7.5$, 7.5, 1.1 Hz), $6.72(1 \mathrm{H}, \mathrm{dd}, J=8.1,0.7 \mathrm{~Hz}), 3.65(2 \mathrm{H}, \mathrm{br}), 2.15(3 \mathrm{H}, \mathrm{s})$.

$\mathbf{H}_{2} / \mathbf{P t}-\mathbf{C}[\mathrm{V}]$ as the reducing agent: A mixture of $\mathbf{1 2 b}(0.100 \mathrm{~g}, 0.43 \mathrm{mml})$ and $1 \%$ Pt-C [V] $(10 \mathrm{mg})$ in $\mathrm{MeOH}(1 \mathrm{~mL})$ was hydrogenated under $1 \mathrm{~atm} \mathrm{H}_{2}$ (balloon) for $8 \mathrm{~h}$ until all the starting material was consumed. The catalyst was removed by filtration, and the solvent was removed under vacuum. The residue was chromatographed with $10 \%$ EtOAc/hexanes to afford the product as an oil $(0.080 \mathrm{~g}, 93 \%)$.

\section{2-(2,2-Dichlorovinyl)-phenylamine (13a)}




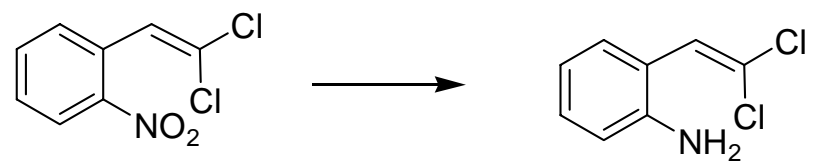

The procedure for the preparation of $\mathbf{1 2 b}$ was followed using 2-nirobenzaldehyde (20 mmol scale). Product 12a was obtained as a yellow solid (3.44 g, 79\%).

A mixture of 12a $(0.100 \mathrm{~g}, 0.46 \mathrm{mml})$ and $1 \% \mathrm{Pt}-\mathrm{C}[\mathrm{V}](10 \mathrm{mg})$ in $\mathrm{MeOH}(1 \mathrm{~mL})$ was hydrogenated under 1 atm $\mathrm{H}_{2}$ (balloon) for $4 \mathrm{~h}$ until all the starting material was consumed. The catalyst was removed by filtration and the solvent was removed under vacuum. The residue was chromatographed with 10\% EtOAc/hexanes to afford the product as an off-white solid (0.081 g, 94\%).

\section{$N$-[2-(2,2-Dibromovinyl)-phenyl]-acetamide (14)}<smiles>Nc1ccccc1C=C(Br)Br</smiles><smiles>CC(=O)Nc1ccccc1C=C(Br)Br</smiles>

To a solution of 1a $(1.385 \mathrm{~g}, 5 \mathrm{mmol})$ and pyridine $(0.59 \mathrm{~g}, 7.5 \mathrm{mmol})$ in DCM $(15 \mathrm{~mL})$ was added dropwise acetic anhydride $(0.76 \mathrm{~g}, 7.5 \mathrm{mmol})$. The mixture was warmed slowly to rt, stirred for an additional $3 \mathrm{~h}$, and diluted with $\mathrm{Et}_{2} \mathrm{O}(30 \mathrm{~mL})$. The mixture was washed with $\mathrm{NaHSO}_{4}(20 \%, 2 \times 20 \mathrm{~mL}), \mathrm{NaHCO}_{3}(40 \mathrm{~mL})$, brine $(15 \mathrm{~mL})$, and dried over $\mathrm{MgSO}_{4}$. The crude mixture was purified by flash chromatography using $50 \%$ EtOAc in hexanes to afford the product as a white crystalline solid $(1.60 \mathrm{~g}, 100 \%) .{ }^{1} \mathrm{H}$ NMR $\left(300 \mathrm{MHz}, \mathrm{CDCl}_{3}\right) \delta 7.48(1 \mathrm{H}, \mathrm{d}, J=7.9 \mathrm{~Hz}), 7.40-7.32(3 \mathrm{H}, \mathrm{m}), 7.19-7.14(2 \mathrm{H}, \mathrm{m}), 2.20$ $(3 \mathrm{H}, \mathrm{s}) .{ }^{13} \mathrm{C} \mathrm{NMR}\left(100 \mathrm{MHz}, \mathrm{CDCl}_{3}\right) \delta 168.7,134.8,133.9,129.6,129.2,128.1,125.1$, 123.6, 94.6, 24.7.

\section{Benzyl-[2-(2,2-dibromovinyl)-phenyl]-amine (20a)}



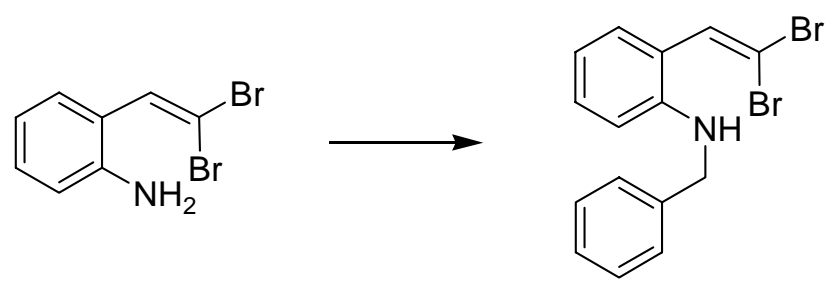

To a suspension of $1 \mathrm{a}(1.385 \mathrm{~g}, 5 \mathrm{mmol})$ and $\mathrm{K}_{2} \mathrm{CO}_{3}(0.834 \mathrm{~g}, 6 \mathrm{mmol})$ in DMF (15 $\mathrm{ml}$ ) was added $\mathrm{BnBr}(1.03 \mathrm{~g}, 6 \mathrm{mmol})$. The mixture was stirred at $\mathrm{rt}$ for $48 \mathrm{~h}$, diluted with $\mathrm{Et}_{2} \mathrm{O}(20 \mathrm{~mL})$, washed with $\mathrm{H}_{2} \mathrm{O}(3 \times 20 \mathrm{~mL})$, brine $(15 \mathrm{~mL})$, and dried over $\mathrm{Na}_{2} \mathrm{SO}_{4}$. The crude material was purified by flash chromatography (2.5\% EtOAc in hexanes) to afford a white crystalline solid $\left(1.40 \mathrm{~g}, 76 \%\right.$ ). mp $93-95^{\circ} \mathrm{C}$. IR (neat, $\left.\mathrm{cm}^{-1}\right)$ : 3433, 1600, 1576, 1509, 1449, 1324, 1247. ${ }^{1} \mathrm{H}$ NMR (300 MHz, $\left.\mathrm{CDCl}_{3}\right) \delta$ 7.36-7.27 (7H, m), $7.19(1 \mathrm{H}, \mathrm{t}, J$ $=7.6 \mathrm{~Hz}), 6.74(1 \mathrm{H}, \mathrm{t}, J=7.6 \mathrm{~Hz}), 6.62(1 \mathrm{H}, \mathrm{d}, J=8.2 \mathrm{~Hz}), 4.37(2 \mathrm{H}, \mathrm{d}, J=4.9 \mathrm{~Hz})$, $4.02(1 \mathrm{H}, \mathrm{br}) .{ }^{13} \mathrm{C}$ NMR $\left(75 \mathrm{MHz}, \mathrm{CDCl}_{3}\right) \delta 145.0,139.1,134.2,130.1,129.5,128.9$, 127.5, 121.8, 117.3, 111.3, 93.6, 48.2. HRMS (ESI) calc'd for $\mathrm{C}_{15} \mathrm{H}_{14} \mathrm{Br}_{2} \mathrm{~N}\left([\mathrm{M}+\mathrm{H}]^{+}\right)$: 365.9487. Found: 365.9482.

\section{[2-(2,2-Dibromovinyl)phenyl]isopropylamine (20b)}

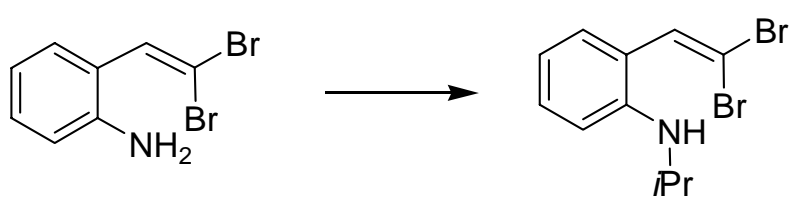

To a solution of 1a $(0.554 \mathrm{~g}, 2 \mathrm{mmol})$ in 1,2-dichloroethane $(6 \mathrm{~mL})$ was added 2methoxypropene $(0.287 \mathrm{~mL})$, HOAc $(0.114 \mathrm{~mL})$ and $\mathrm{NaHB}(\mathrm{OAc})_{3}(0.636 \mathrm{~g}, 3 \mathrm{mmol})$. The mixture was stirred at $\mathrm{rt}$ for $20 \mathrm{~h}$ and quenched by the addition of $\mathrm{NaHCO}_{3}(20 \mathrm{~mL})$, extracted with DCM $(2 \times 25 \mathrm{~mL})$ and dried over $\mathrm{Na}_{2} \mathrm{SO}_{4}$. The residue after removal of solvent was chromatographed with 5\% EtOAc in hexanes to afford the product as a colorless oil (0.636 g, 100\%). IR (neat, $\mathrm{cm}^{-1}$ ): 3412, 2966, 1601, 1504, 1455, 1316, 1260, 1175. ${ }^{1} \mathrm{H}$ NMR (400 MHz, $\left.\mathrm{CDCl}_{3}\right) \delta$ 7.25-7.18 (2H, m), 6.70-6.63 (2H, m), $3.64(1 \mathrm{H}, \mathrm{br})$, $3.37(1 \mathrm{H}, \mathrm{br}), 1.22(6 \mathrm{H}, \mathrm{d}, J=6.2 \mathrm{~Hz}) .{ }^{13} \mathrm{C} \mathrm{NMR}\left(100 \mathrm{MHz}, \mathrm{CDCl}_{3}\right) \delta$ 144.5, 134.4, 130.0, 129.6, 121.7, 116.5, 111.5, 93.1, 44.3, 23.2. HRMS (EI) calc'd for $\mathrm{C}_{11} \mathrm{H}_{13} \mathrm{NBr}_{2}$ $\left([\mathrm{M}]^{+}\right) 316.9415$. Found: 316.9420 . 


\section{Synthesis of 2-Substituted, 1,2-disubstituted and 2,3-disubstituted Indoles via Pd-Catalyzed Tandem C-N/C-C Couplings}

\section{1-(2-Phenylindol-1-yl)ethanone (15a)}

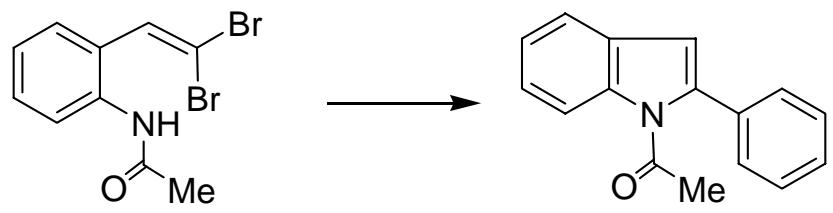

General procedure for the synthesis of 1-acetyl-2-arylindole 15: To a 5-mL roundbottomed flask was charged with acetamide $14(0.096 \mathrm{~g}, 0.3 \mathrm{mmol})$, phenylboronic acid (0.073 g, $0.6 \mathrm{mmol}), \mathrm{K}_{2} \mathrm{CO}_{3}(0.166 \mathrm{~g}, 1.2 \mathrm{mmol}), \mathrm{Pd}_{2}(\mathrm{dba})_{3}(13.7 \mathrm{mg}, 0.015 \mathrm{mmol})$, and $\mathrm{P}(\mathrm{o}-\mathrm{tol})_{3}(18.2 \mathrm{mg}, 0.06 \mathrm{mmol})$. After the flask was purged with argon for $10 \mathrm{~min}$, toluene $(2 \mathrm{~mL})$ was added, and the mixture was heated at $100^{\circ} \mathrm{C}$ for $15 \mathrm{~h}$. The mixture was diluted with $\mathrm{Et}_{2} \mathrm{O}(20 \mathrm{~mL})$ and filtered through celite. The crude material was purified by flash chromatography using $5 \% \rightarrow 10 \%$ EtOAc in hexanes to afford 15a as a colorless oil (0.050 g, 72\%). ${ }^{1} \mathrm{H}$ NMR (400 MHz, $\left.\mathrm{CDCl}_{3}\right) \delta 8.36(1 \mathrm{H}, \mathrm{d}, J=8.4 \mathrm{~Hz}), 7.56$ $(1 \mathrm{H}, \mathrm{d}, J=7.7 \mathrm{~Hz}), 7.49-7.40(5 \mathrm{H}, \mathrm{m}), 7.36(1 \mathrm{H}, \mathrm{ddd}, J=7.8,7.8,1.3 \mathrm{~Hz}), 7.29(1 \mathrm{H}$, ddd, 7.4, 7.4, $1.2 \mathrm{~Hz}), 6.62(1 \mathrm{H}, \mathrm{s}), 2.08(3 \mathrm{H}, \mathrm{s}) .{ }^{13} \mathrm{C} \mathrm{NMR}\left(100 \mathrm{MHz}, \mathrm{CDCl}_{3}\right) \delta 171.7$, 139.9 , 137.9, 134.4, 129.2, 129.2, 129.0, 128.8, 125.3, 123.9, 120.6, 116.2, 111.8, 28.1.

\section{1-[2-(4-Acetylphenyl)-indol-1-yl]-ethanone (15b)}<smiles>CC(=O)Nc1ccccc1C=C(Br)Br</smiles><smiles>CC(=O)c1ccc(-c2cc3ccccc3n2C(C)=O)cc1</smiles>

The general procedure for the preparation of 15 was followed using 14 (0.096 g, 0.3 mmol), 4-acetylphenyl boronic acid (0.098 g, $0.6 \mathrm{mmol}), \mathrm{K}_{2} \mathrm{CO}_{3}(0.166 \mathrm{~g}, 1.2 \mathrm{mmol})$, $\mathrm{Pd}_{2}(\mathrm{dba})_{3}(13.7 \mathrm{mg}, 0.015 \mathrm{mmol})$, and $\mathrm{P}(o-\text { tol })_{3}(18.2 \mathrm{mg}, 0.06 \mathrm{mmol})$. After heating at $100{ }^{\circ} \mathrm{C}$ for $18 \mathrm{~h}$, the product was obtained as an oil using flash chromatography with $30 \%$ EtOAc in hexanes $(0.019 \mathrm{~g}, 23 \%)$. IR (neat, $\left.\mathrm{cm}^{-1}\right)$ : 3063, 1707, 1682, 1604, 1365, 1297 , 
1267. ${ }^{1} \mathrm{H}$ NMR $\left(300 \mathrm{MHz}, \mathrm{CDCl}_{3}\right) \delta 8.30(1 \mathrm{H}, \mathrm{d}, J=8.2 \mathrm{~Hz}), 8.05(2 \mathrm{H}, \mathrm{d}, J=8.3 \mathrm{~Hz})$, 7.59 (3H, d, $J=8.2 \mathrm{~Hz}), 7.39$ (1H, ddd, $J=7.8,7.8,1.3 \mathrm{~Hz}), 7.31(1 \mathrm{H}$, ddd, $J=7.5,7.5$, $1.0 \mathrm{~Hz}), 6.72(1 \mathrm{H}, \mathrm{s}), 2.66(3 \mathrm{H}, \mathrm{s}), 2.17(3 \mathrm{H}, \mathrm{s}) .{ }^{13} \mathrm{C} \mathrm{NMR}\left(75 \mathrm{MHz}, \mathrm{CDCl}_{3}\right) \delta 197.5$, 171.1, 138.9, 138.8, 138.2, 136.9, 129.1, 129.0, 128.9, 125.9, 124.1, 121.0, 116.0, 113.0, 28.3, 26.9. HRMS (ESI) calc'd for $\mathrm{C}_{18} \mathrm{H}_{16} \mathrm{NO}_{2}\left([\mathrm{M}]^{+}\right)$278.1175. Found: 278.1165 .

\section{1-(2-o-Tolylindol-1-yl)-ethanone (15c)}
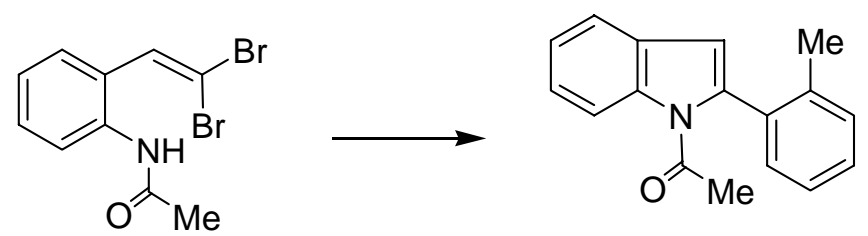

General procedure for the preparation of $\mathbf{1 5}$ was followed using $\mathbf{1 4}(0.096 \mathrm{~g}, 0.3$ mmol), o-tolyl boronic acid (0.082 g, $0.6 \mathrm{mmol}), \mathrm{K}_{2} \mathrm{CO}_{3}(0.166 \mathrm{~g}, 1.2 \mathrm{mmol}), \mathrm{Pd}_{2}(\mathrm{dba})_{3}$ (13.7 mg, $0.015 \mathrm{mmol})$, and $\mathrm{P}(\mathrm{o} \text {-tol })_{3}(18.2 \mathrm{mg}, 0.06 \mathrm{mmol})$. After heating at $100{ }^{\circ} \mathrm{C}$ for $18 \mathrm{~h}$, the product was obtained as an oil using flash chromatography $(0.013 \mathrm{~g}, 17 \%)$. IR $\left(\right.$ neat, $\left.\mathrm{cm}^{-1}\right): 3051,1701,1447,1369,1303 .{ }^{1} \mathrm{H}$ NMR $\left(300 \mathrm{MHz}, \mathrm{CDCl}_{3}\right) \delta 8.46(1 \mathrm{H}, \mathrm{dm}$, $\left.J^{\mathrm{d}}=8.4 \mathrm{~Hz}\right), 7.56\left(1 \mathrm{H}, \mathrm{dm}, J^{\mathrm{d}}=8.0 \mathrm{~Hz}\right), 7.39-7.26(6 \mathrm{H}, \mathrm{m}), 6.52(1 \mathrm{H}, \mathrm{d}, J=0.7 \mathrm{~Hz}), 2.23$ $(3 \mathrm{H}, \mathrm{s}), 1.94(3 \mathrm{H}, \mathrm{s}) .{ }^{13} \mathrm{C} \mathrm{NMR}\left(75 \mathrm{MHz}, \mathrm{CDCl}_{3}\right) \delta 171.1,138.7,137.7,137.4,134.2$, 130.6, 130.6, 129.5, 126.3, 125.2, 123.9, 120.4, 117.0, 111.6, 26.8, 20.2. HRMS (EI) calc'd for $\mathrm{C}_{17} \mathrm{H}_{15} \mathrm{NO}_{2}\left([\mathrm{M}]^{\dagger}\right)$ 249.1154. Found: 249.1158 .

\section{2-o-Tolyl-1H-indole (17b)}

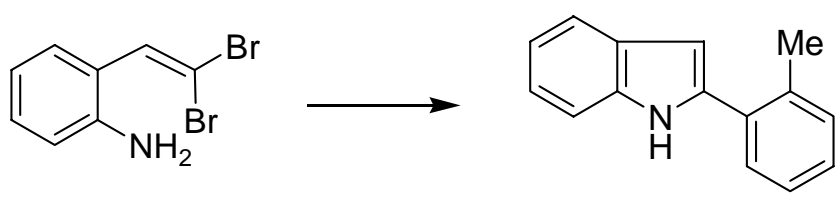

General procedure A for the Pd-catalyzed tandem coupling was followed. A mixture of $1 \mathrm{a}(0.277 \mathrm{~g}, 1 \mathrm{mmol})$, o-tolylboronic acid $(0.204 \mathrm{~g}, 1.5 \mathrm{mmol}), \mathrm{K}_{3} \mathrm{PO}_{4} \cdot \mathrm{H}_{2} \mathrm{O}(1.15 \mathrm{~g}, 5$ $\mathrm{mmol})$, and a catalyst solution $\left(\mathrm{Pd}(\mathrm{OAc})_{2}(2.3 \mathrm{mg}, 1 \mathrm{~mol} \%)\right.$ and S-Phos $(8.2 \mathrm{mg}, 2$ mol\%)) in PhMe (5 mL) was heated at $90{ }^{\circ} \mathrm{C}$ for $4 \mathrm{~h}$. After an aqueous workup, the crude material was purified by flash chromatography (5\% EtOAc in hexanes) to afford a white 
crystalline solid $(0.170 \mathrm{~g}, 82 \%) .{ }^{1} \mathrm{H}$ NMR $\left(400 \mathrm{MHz}, \mathrm{CDCl}_{3}\right) \delta 8.12(1 \mathrm{H}, \mathrm{br}), 7.65-7.61$ $(1 \mathrm{H}, \mathrm{m}), 7.46(1 \mathrm{H}, \mathrm{m}), 7.40(1 \mathrm{H}, \mathrm{d}, J=7.9 \mathrm{~Hz}), 7.30-7.06(5 \mathrm{H}, \mathrm{m}), 6.61(1 \mathrm{H}, \mathrm{s}), 2.50$ $(3 \mathrm{H}, \mathrm{s})$.

\section{2-p-Tolyl-1H-indole (17c)}<smiles>Nc1ccccc1C=C(Br)Br</smiles><smiles>Cc1ccc(-c2cc3ccccc3[nH]2)cc1</smiles>

General procedure A for the Pd-catalyzed tandem coupling was followed. A mixture of $1 \mathrm{a}(0.139 \mathrm{~g}, 0.5 \mathrm{mmol})$, -tolylboronic acid $(0.102 \mathrm{~g}, 0.75 \mathrm{mmol}), \mathrm{K}_{3} \mathrm{PO}_{4} \cdot \mathrm{H}_{2} \mathrm{O}(0.58 \mathrm{~g}$, $2.5 \mathrm{mmol})$, and a catalyst solution $\left(\mathrm{Pd}(\mathrm{OAc})_{2}(1.2 \mathrm{mg}, 1 \mathrm{~mol} \%)\right.$ and $\mathrm{S}-\mathrm{Phos}(4.1 \mathrm{mg}, 2$ mol\%) in PhMe $(2.5 \mathrm{~mL})$ ) was heated at $90{ }^{\circ} \mathrm{C}$ for $5 \mathrm{~h}$. After an aqueous workup, the crude material was purified by flash chromatography (10\% EtOAc in hexanes) to afford a white crystalline solid $(0.091 \mathrm{~g}, 88 \%) .{ }^{1} \mathrm{H}$ NMR $\left(300 \mathrm{MHz}, \mathrm{CDCl}_{3}\right) \delta 8.27(1 \mathrm{H}, \mathrm{br}), 7.61$ $(1 \mathrm{H}, \mathrm{d}, J=7.8 \mathrm{~Hz}), 7.55(2 \mathrm{H}, \mathrm{d}, J=8.2 \mathrm{~Hz}), 7.38(1 \mathrm{H}, \mathrm{d}, J=8.0 \mathrm{~Hz}), 7.24(2 \mathrm{H}, \mathrm{d}, J=7.9$ $\mathrm{Hz}), 7.18(1 \mathrm{H}$, ddd, $J=7.5,7.5,1.3 \mathrm{~Hz}), 7.11(1 \mathrm{H}, \mathrm{ddd}, J=7.3,7.3,1.3 \mathrm{~Hz}), 6.78(1 \mathrm{H}$, dd, $J=2.2,0.8 \mathrm{~Hz}), 2.39(3 \mathrm{H}, \mathrm{s})$.

\section{2-(4-Methoxyphenyl)-1H-indole (17d)}

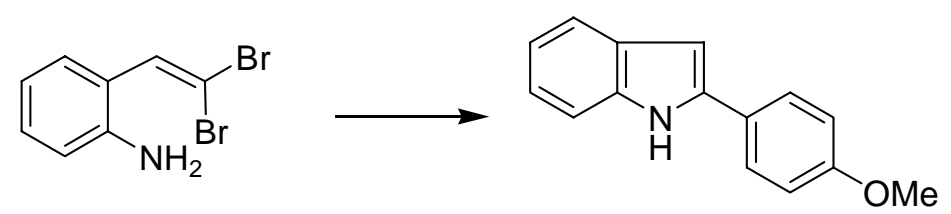

General procedure A for the Pd-catalyzed tandem coupling was followed. A mixture of $1 \mathrm{a}(0.277 \mathrm{~g}, 1 \mathrm{mmol}), 4$-methoxylphenylboronic acid (0.228 g, $1.5 \mathrm{mmol}), \mathrm{K}_{3} \mathrm{PO}_{4} \cdot \mathrm{H}_{2} \mathrm{O}$ $(1.15 \mathrm{~g}, 5 \mathrm{mmol})$, and a catalyst solution $\left(\mathrm{Pd}(\mathrm{OAc})_{2}(2.3 \mathrm{mg}, 1 \mathrm{~mol} \%)\right.$ and S-Phos $(8.2$ $\mathrm{mg}, 2 \mathrm{~mol} \%)$ in $\mathrm{PhMe}(5 \mathrm{~mL}))$ was heated at $90{ }^{\circ} \mathrm{C}$ for $2 \mathrm{~h}$. After an aqueous workup, the crude material was purified by flash chromatography $(10 \rightarrow 20 \%$ EtOAc in hexanes) to afford a white crystalline solid $(0.186 \mathrm{~g}, 83 \%)$ as the title product. ${ }^{1} \mathrm{H}$ NMR $(300 \mathrm{MHz}$, $\left.\mathrm{CDCl}_{3}\right) \delta 8.24(1 \mathrm{H}, \mathrm{br}), 7.61-7.57(3 \mathrm{H}, \mathrm{m}), 7.38(1 \mathrm{H}, \mathrm{d}, J=7.8 \mathrm{~Hz}), 7.17(1 \mathrm{H}, \mathrm{ddd}, J=$ 
7.6, 7.6, 1.3 Hz), $7.10(1 \mathrm{H}, \mathrm{ddd}, J=7.4,7.4,1.3 \mathrm{~Hz}), 6.98\left(2 \mathrm{H}, \mathrm{dm}, J^{\mathrm{d}}=8.8 \mathrm{~Hz}\right), 6.71$ $(1 \mathrm{H}, \mathrm{dd}, J=2.1,1.3 \mathrm{~Hz}), 3.86(3 \mathrm{H}, \mathrm{s})$.

\section{2-(4-Methoxy-2-methylphenyl)-1H-indole (17e)}<smiles>COc1ccc(-c2cc3ccccc3[nH]2)c(C)c1</smiles>

General procedure A for the Pd-catalyzed tandem coupling was followed. A mixture of 1a $(0.277 \mathrm{~g}, 1 \mathrm{mmol})$, 4-methoxyl-2-methylphenylboronic acid (0.249 g, $1.5 \mathrm{mmol})$, $\mathrm{K}_{3} \mathrm{PO}_{4} \cdot \mathrm{H}_{2} \mathrm{O}(1.15 \mathrm{~g}, 5 \mathrm{mmol})$, and a catalyst solution $\left(\mathrm{Pd}(\mathrm{OAc})_{2}(2.3 \mathrm{mg}, 1 \mathrm{~mol} \%)\right.$ and $\mathrm{S}-$ Phos ( $8.2 \mathrm{mg}, 2 \mathrm{~mol} \%)$ in PhMe $(5 \mathrm{~mL})$ ) was heated at $90{ }^{\circ} \mathrm{C}$ for $5.5 \mathrm{~h}$. After an aqueous workup, the crude material was purified by flash chromatography $(5 \% \rightarrow 10 \%$ EtOAc in hexanes) to afford a white crystalline solid $(0.187 \mathrm{~g}, 79 \%)$ as the title product. ${ }^{7}{ }^{1} \mathrm{H}$ NMR $\left(300 \mathrm{MHz}, \mathrm{CDCl}_{3}\right) \delta 8.05(1 \mathrm{H}, \mathrm{br}), 7.63(1 \mathrm{H}, \mathrm{d}, J=7.6 \mathrm{~Hz}), 7.37(2 \mathrm{H}, \mathrm{d}, J=8.5 \mathrm{~Hz})$, $7.18(1 \mathrm{H}$, ddd, $J=7.5,7.5,1.3 \mathrm{~Hz}), 7.12(1 \mathrm{H}, \mathrm{ddd}, J=7.3,7.3,1.1 \mathrm{~Hz}), 6.85-8.80(2 \mathrm{H}$, m), $6.53(1 \mathrm{H}, \mathrm{dd}, J=2.0,0.9 \mathrm{~Hz}), 3.83(3 \mathrm{H}, \mathrm{s}), 2.46(3 \mathrm{H}, \mathrm{s})$.

\section{2-Naphthalen-2-yl-1H-indole (17f)}

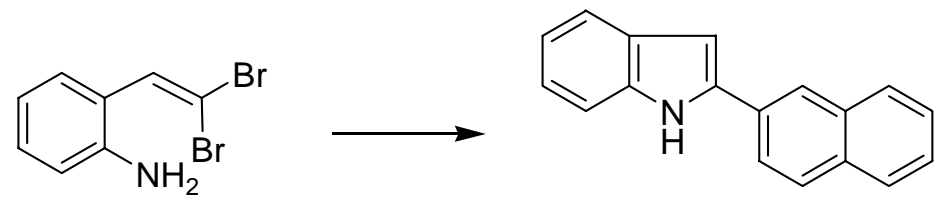

General procedure A for the Pd-catalyzed tandem coupling was followed. A mixture of $1 \mathrm{a}(0.277 \mathrm{~g}, 1 \mathrm{mmol}), 2$-naphthaleneboronic acid $(0.258 \mathrm{~g}, 1.5 \mathrm{mmol}), \mathrm{K}_{3} \mathrm{PO}_{4} \cdot \mathrm{H}_{2} \mathrm{O}$ $(1.15 \mathrm{~g}, 5 \mathrm{mmol})$, and a catalyst solution $\left(\mathrm{Pd}(\mathrm{OAc})_{2}(2.3 \mathrm{mg}, 1 \mathrm{~mol} \%)\right.$ and S-Phos $(8.2$ $\mathrm{mg}, 2 \mathrm{~mol} \%)$ in PhMe $(5 \mathrm{~mL}))$ was heated at $90{ }^{\circ} \mathrm{C}$ for $7 \mathrm{~h}$. After an aqueous workup, the crude material was purified by flash chromatography (10\% EtOAc in hexanes) to afford a

\footnotetext{
${ }^{7}$ Pigerol, C.; Chandavoine, M. M.; De Cointet de Fillain, P.; Nanthavong, S. In Ger. Offen.; (Labaz, Fr.). De 2524659, 1975, 37 pp.
} 
white crystalline solid $(0.199 \mathrm{~g}, 82 \%)$ as the title product. ${ }^{8}{ }^{1} \mathrm{H}$ NMR $\left(300 \mathrm{MHz}, \mathrm{CDCl}_{3}\right) \delta$ $8.45(1 \mathrm{H}, \mathrm{br}), 8.03(1 \mathrm{H}, \mathrm{s}), 7.90-7.80(4 \mathrm{H}, \mathrm{m}), 7.66(1 \mathrm{H}, \mathrm{d}, J=7.3 \mathrm{~Hz}), 7.53-7.44(2 \mathrm{H}$, m), $7.42(1 \mathrm{H}, \mathrm{d}, J=8.0 \mathrm{~Hz}), 7.22(1 \mathrm{H}, \mathrm{ddd}, J=7.5,7.5,1.3 \mathrm{~Hz}), 7.14(1 \mathrm{H}$, ddd, $J=7.4$, 7.4, $1.2 \mathrm{~Hz}), 6.94(1 \mathrm{H}, \mathrm{dd}, J=2.2,0.8 \mathrm{~Hz})$.

\section{2-(4-Trifluoromethylphenyl)-1H-indole (17g)}

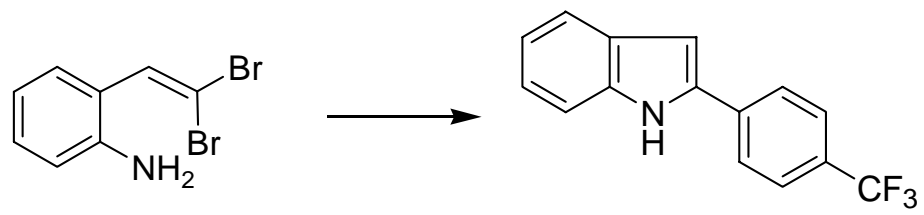

General procedure A for the Pd-catalyzed tandem coupling was followed. A mixture of 1a $(0.277 \mathrm{~g}, 1 \mathrm{mmol})$, 4-trifluoromethylphenylboronic acid (0.285 g, $1.5 \mathrm{mmol})$, $\mathrm{K}_{3} \mathrm{PO}_{4} \cdot \mathrm{H}_{2} \mathrm{O}(1.15 \mathrm{~g}, 5 \mathrm{mmol})$, and a catalyst solution $\left(\mathrm{Pd}(\mathrm{OAc})_{2}(2.3 \mathrm{mg}, 1 \mathrm{~mol} \%)\right.$ and $\mathrm{S}-$ Phos $(8.2 \mathrm{mg}, 2 \mathrm{~mol} \%)$ in PhMe $(5 \mathrm{~mL}))$ was heated at $90{ }^{\circ} \mathrm{C}$ for $7 \mathrm{~h}$. After an aqueous workup, the crude material was purified by flash chromatography $5 \%$ EtOAc in hexanes) to afford a white crystalline solid (0.196 g, 75\%).

\section{2-(4-Chlorophenyl)-1H-indole (17h)}

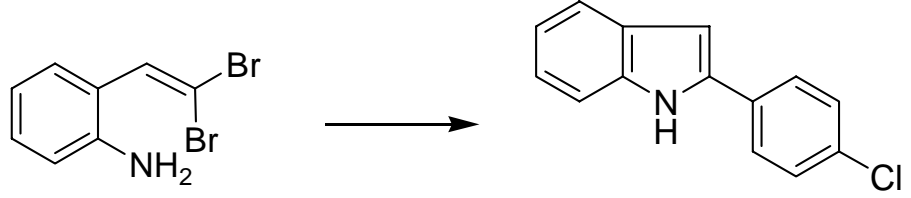

General procedure A for the Pd-catalyzed tandem coupling was followed. A mixture of $1 \mathrm{a}(0.083 \mathrm{~g}, 0.3 \mathrm{mmol}), 4$-chlorophenylboronic acid $(0.070 \mathrm{~g}, 0.45 \mathrm{mmol}), \mathrm{K}_{3} \mathrm{PO}_{4} \cdot \mathrm{H}_{2} \mathrm{O}$ (0.35 g, $1.5 \mathrm{mmol})$, and a catalyst solution $\left(\mathrm{Pd}(\mathrm{OAc})_{2}(2.3 \mathrm{mg}, 3.3 \mathrm{~mol} \%)\right.$ and S-Phos $(8.2 \mathrm{mg}, 6.6 \mathrm{~mol} \%)$ in $\mathrm{PhMe}(1.5 \mathrm{~mL}))$ was heated at $90{ }^{\circ} \mathrm{C}$ for $2.5 \mathrm{~h}$. After an aqueous workup, the crude material was purified by flash chromatography $(10 \%$ EtOAc in hexanes) to afford a white crystalline solid (0.037 g, 57\%). ${ }^{1} \mathrm{H}$ NMR (300 $\left.\mathrm{MHz}, \mathrm{CDCl}_{3}\right)$ $\delta 8.25(1 \mathrm{H}, \mathrm{br}), 7.62(1 \mathrm{H}, \mathrm{d}, J=7.2 \mathrm{~Hz}), 7.55(2 \mathrm{H}, \mathrm{dm}, J=8.5 \mathrm{~Hz}), 7.41-7.36(3 \mathrm{H}, \mathrm{m})$,

\footnotetext{
${ }^{8}$ Baumgartner, M. T.; Nazareno, M. A.; Murguia, M. C.; Pierini, A. B.; Rossi, R. A. Synthesis 1999, 2053.
} 
$7.20(1 \mathrm{H}, \mathrm{ddd}, J=7.6,7.6,1.0 \mathrm{~Hz}), 7.12(1 \mathrm{H}, \mathrm{ddd}, 7.4,7.4,1.1), 6.79(1 \mathrm{H}, \mathrm{d}, J=2.2$ $\mathrm{Hz})$.

\section{2-(3-Chlorophenyl)-1H-indole (17i)}

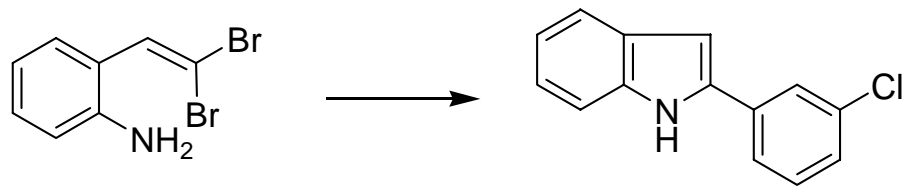

General procedure A for the Pd-catalyzed tandem coupling was followed. A mixture of $1 \mathrm{a}(0.083 \mathrm{~g}, 0.3 \mathrm{mmol}), 3$-chlorophenylboronic acid $(0.070 \mathrm{~g}, 0.45 \mathrm{mmol}), \mathrm{K}_{3} \mathrm{PO}_{4} \cdot \mathrm{H}_{2} \mathrm{O}$ $(0.35 \mathrm{~g}, 1.5 \mathrm{mmol})$, and a catalyst solution $\left(\mathrm{Pd}(\mathrm{OAc})_{2}(2.3 \mathrm{mg}, 3.3 \mathrm{~mol} \%)\right.$ and S-Phos $(8.2 \mathrm{mg}, 6.6 \mathrm{~mol} \%)$ in PhMe $(1.5 \mathrm{~mL})$ ) was heated at $90{ }^{\circ} \mathrm{C}$ for $2.5 \mathrm{~h}$. After an aqueous workup, the crude material was purified by flash chromatography $(10 \%$ EtOAc in hexanes) to afford a white crystalline solid $(0.041 \mathrm{~g}, 60 \%) .{ }^{9}{ }^{1} \mathrm{H}$ NMR $\left(300 \mathrm{MHz}, \mathrm{CDCl}_{3}\right)$ $\delta 8.24(1 \mathrm{H}, \mathrm{br}), 7.64-7.60(2 \mathrm{H}, \mathrm{m}), 7.49(1 \mathrm{H}, \mathrm{d}, J=7.7 \mathrm{~Hz}), 7.39-7.10(5 \mathrm{H}, \mathrm{m}), 6.82(1 \mathrm{H}$, d, $J=2.2 \mathrm{~Hz})$.

\section{2-Thiophen-3-yl-1H-indole (17j)}

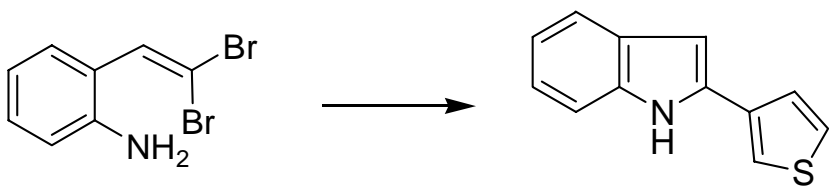

General procedure A for the Pd-catalyzed tandem coupling was followed. A mixture of 1a $(0.139 \mathrm{~g}, 0.5 \mathrm{mmol}), 3$-thiopheneboronic acid $(0.096 \mathrm{~g}, 0.75 \mathrm{mmol}), \mathrm{K}_{3} \mathrm{PO}_{4} \cdot \mathrm{H}_{2} \mathrm{O}$ $(0.58 \mathrm{~g}, 2.5 \mathrm{mmol})$, and a catalyst solution $\left(\mathrm{Pd}(\mathrm{OAc})_{2}(2.3 \mathrm{mg}, 2 \mathrm{~mol} \%)\right.$ and S-Phos $(8.2$ $\mathrm{mg}, 4 \mathrm{~mol} \%$ ) in $\mathrm{PhMe}(2.5 \mathrm{~mL}))$ was heated at $90{ }^{\circ} \mathrm{C}$ for $12 \mathrm{~h}$. After an aqueous workup, the crude material was purified by flash chromatography (7\% EtOAc in hexanes) to afford a white crystalline solid $(0.086 \mathrm{~g}, 86 \%)$. $\mathrm{R}_{\mathrm{f}}=0.20$ (7\% EtOAc/Hexanes). $\mathrm{mp} 212$ $214{ }^{\circ} \mathrm{C}$ (sealed tube). IR (neat, $\mathrm{cm}^{-1}$ ): 3416, 3091, 1452, 1418, 1340, 1085. ${ }^{1} \mathrm{H}$ NMR (400 $\left.\mathrm{MHz}, \mathrm{CDCl}_{3}\right) \delta 8.17(1 \mathrm{H}, \mathrm{br}), 7.60(1 \mathrm{H}, \mathrm{d}, J=7.7 \mathrm{~Hz}), 7.39(2 \mathrm{H}, \mathrm{s}), 7.36(1 \mathrm{H}, \mathrm{d}, J=7.7$

\footnotetext{
${ }^{9}$ Inion, H.; De Vogelaer, H.; Van Durme, E.; Descamps, M.; Brotelle, R.; Charlier, R.; Colot, M. Eur. J. Med. Chem. 1975, 10, 276.
} 
$\mathrm{Hz}), 7.24(1 \mathrm{H}, \mathrm{s}), 7.18(1 \mathrm{H}, \mathrm{ddd}, J=7.6 .7 .6,1.1 \mathrm{~Hz}), 7.11(1 \mathrm{H}, \mathrm{ddd}, J=7.4 .7 .4,1.1$ $\mathrm{Hz}), 6.70(1 \mathrm{H}, \mathrm{d}, J=1.3 \mathrm{~Hz}) .{ }^{13} \mathrm{C} \mathrm{NMR}\left(100 \mathrm{MHz}, \mathrm{CDCl}_{3}\right) \delta 136.6,134.3,134.1,129.3$, $126.9,125.9,122.5,120.8,120.5,119.3,110.9,100.2$. HRMS (EI) calc'd for $\mathrm{C}_{12} \mathrm{H}_{9} \mathrm{NS}$ ([M] $\left.{ }^{+}\right)$199.0456. Found: 199.0453.

\section{2-Styryl-1H-indole (17l)}

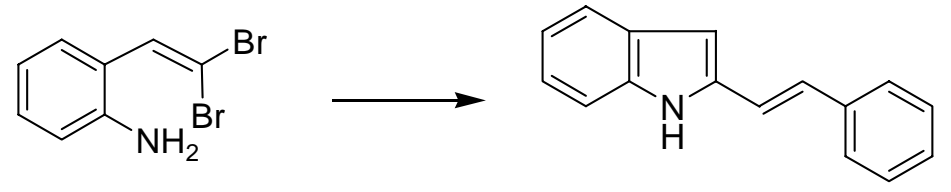

General procedure A for the Pd-catalyzed tandem coupling was followed. A mixture of 1a $(0.139 \mathrm{~g}, 0.5 \mathrm{mmol})$, trans-2-phenylvinylboronic acid $(0.111 \mathrm{~g}, 0.75 \mathrm{mmol})$, $\mathrm{K}_{3} \mathrm{PO}_{4} \cdot \mathrm{H}_{2} \mathrm{O}(0.58 \mathrm{~g}, 2.5 \mathrm{mmol})$, and a catalyst solution $\left(\mathrm{Pd}(\mathrm{OAc})_{2}(2.3 \mathrm{mg}, 2 \mathrm{~mol} \%)\right.$ and S-Phos $(8.2 \mathrm{mg}, 4 \mathrm{~mol} \%)$ in PhMe $(2.5 \mathrm{~mL})$ ) was heated at $90{ }^{\circ} \mathrm{C}$ for $7 \mathrm{~h}$. After an aqueous workup, the crude material was purified by flash chromatography $(5 \% \rightarrow 10 \%$ EtOAc in hexanes) to afford a white crystalline solid $(0.075 \mathrm{~g}, 68 \%) .{ }^{1} \mathrm{H}$ NMR (400 $\left.\mathrm{MHz}, \mathrm{CDCl}_{3}\right) \delta 8.22(1 \mathrm{H}, \mathrm{br}), 7.58(1 \mathrm{H}, \mathrm{d}, J=7.7 \mathrm{~Hz}), 7.50(2 \mathrm{H}, \mathrm{d}, J=7.4 \mathrm{~Hz}), 7.39$ $7.15(7 \mathrm{H}, \mathrm{m}), 6.89(1 \mathrm{H}, \mathrm{d}, J=16.8 \mathrm{~Hz}), 6.61(1 \mathrm{H}, \mathrm{s})$.

\section{2-(1-Ethyl-but-1-enyl)-1H-indole (17m)}

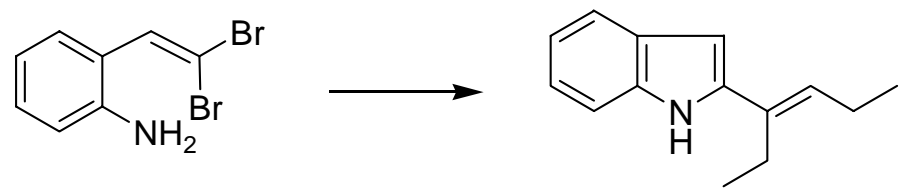

General procedure A for the Pd-catalyzed tandem coupling was followed. A mixture of 1a $(0.134 \mathrm{~g}, 0.48 \mathrm{mmol}), 2$-(cis-1-thyl-but-1-enyl)-benzo[1,3,2]dioxaborole $(0.125 \mathrm{~g}$, $1.2 \mathrm{mmol}), \mathrm{K}_{3} \mathrm{PO}_{4} \cdot \mathrm{H}_{2} \mathrm{O}(0.58 \mathrm{~g}, 2.5 \mathrm{mmol})$, and a catalyst solution $\left(\mathrm{Pd}(\mathrm{OAc})_{2}(3.5 \mathrm{mg}, 3\right.$ mol\%) and S-Phos (12.3 mg, $6 \mathrm{~mol} \%)$ in PhMe $(2.5 \mathrm{~mL}))$ was heated at $90{ }^{\circ} \mathrm{C}$ for $6 \mathrm{~h}$. After an aqueous workup, the crude material was purified by flash chromatography (5\% EtOAc in hexanes) to afford a white crystalline solid $(0.070 \mathrm{~g}, 73 \%)$ as the title product. ${ }^{10}$

${ }^{10}$ Ayguen, A.; Pindur, U. J. Heterocycl. Chem. 2003, 40, 411. 
${ }^{1} \mathrm{H}$ NMR $\left(300 \mathrm{MHz}, \mathrm{CDCl}_{3}\right) \delta 8.05(1 \mathrm{H}, \mathrm{br}), 7.54(1 \mathrm{H}, \mathrm{d}, J=7.8 \mathrm{~Hz}), 7.28(1 \mathrm{H}, \mathrm{dd}, J=$ 8.0, $0.8 \mathrm{~Hz}), 7.13(1 \mathrm{H}$, ddd, $J=7.5,7.5,1.2 \mathrm{~Hz}), 7.05$ (1H, ddd, $J=7.4,7.4,1.2), 6.47$ $(1 \mathrm{H}, \mathrm{d}, J=1.8 \mathrm{~Hz}), 5.76(1 \mathrm{H}, \mathrm{t}, J=7.2 \mathrm{~Hz}), 2.50(2 \mathrm{H}, \mathrm{q}, J=7.6 \mathrm{~Hz}), 2.26(2 \mathrm{H}$, quintet, $J$ $=7.5 \mathrm{~Hz}), 1.13(3 \mathrm{H}, \mathrm{t}, J=7.5 \mathrm{~Hz}), 1.09(3 \mathrm{H}, \mathrm{t}, J=7.5)$.

\section{2-Ethyl-1H-indole (17n)}

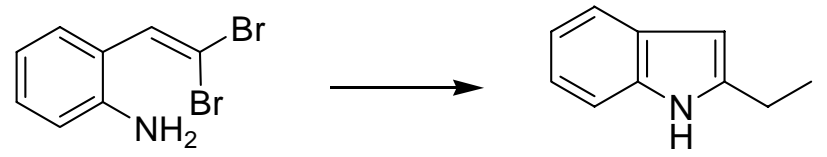

To a round-bottomed flask was charged with $1 \mathrm{a}(0.139 \mathrm{~g}, 0.50 \mathrm{mmol}), \mathrm{K}_{3} \mathrm{PO}_{4} \cdot \mathrm{H}_{2} \mathrm{O}$ (0.58 g, $2.5 \mathrm{mmol}), \mathrm{Pd}_{2}(\mathrm{dba})_{3}(4.6 \mathrm{mg}, 2 \mathrm{~mol} \% \mathrm{Pd}$ ) and S-Phos (10.3 mg, $5 \mathrm{~mol} \%)$. After the mixture was purged with $\mathrm{N}_{2}$ for over $10 \mathrm{~min}$, THF $(2.5 \mathrm{~mL})$ and triethylborane were added, $\mathrm{H}_{2} \mathrm{O}(10 \mu \mathrm{L})$, and the resulting mixture was heated at $60{ }^{\circ} \mathrm{C}$ for $2 \mathrm{~h}$. The mixture was then cooled to $-20{ }^{\circ} \mathrm{C}$, to which $\mathrm{H}_{2} \mathrm{O}_{2}(30 \%, 0.5 \mathrm{~mL})$ was added. The mixture was slowly warmed to rt, and stirred for another $30 \mathrm{~min}$. After a usual aqueous workup, the product was purified by flash chromatography (10\% EtOAc in hexanes) to afford a solid $(0.108 \mathrm{~g}, 77 \%)$ as the title product. ${ }^{11} \mathrm{H}$ NMR $\left(300 \mathrm{MHz}, \mathrm{CDCl}_{3}\right) \delta 7.80(1 \mathrm{H}, \mathrm{br}), 7.52$ $(1 \mathrm{H}, \mathrm{dd}, J=7.3,0.9 \mathrm{~Hz}), 7.26\left(1 \mathrm{H}, \mathrm{dm}, J^{\mathrm{d}}=8.0 \mathrm{~Hz}\right), 7.14-7.06(2 \mathrm{H}, \mathrm{m}), 6.23(1 \mathrm{H}, \mathrm{dd}, J$ $=2.2,1.1 \mathrm{~Hz}), 2.76\left(2 \mathrm{H}, \mathrm{qd}, J^{\mathrm{q}}=7.5, J^{\mathrm{d}}=0.8\right), 1.33\left(3 \mathrm{H}, \mathrm{t}, J^{\mathrm{d}}=7.6\right)$.

\section{2-Hexyl-1H-indole (17o)}

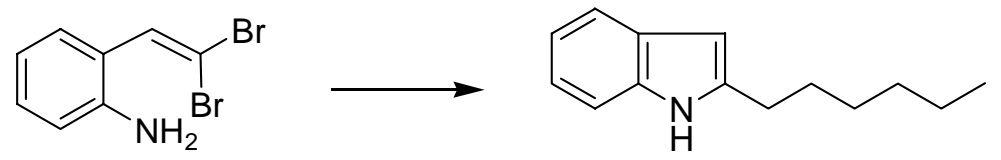

General procedure B was followed. $n$-Hexyl 9-BBN was prepared from 1-hexene (0.063 g, $0.75 \mathrm{mmol})$ and 9-BBN (0.5 M, $1.65 \mathrm{~mL}, 0.825 \mathrm{mmol})$. Reaction of n-hexyl 9BBN, 1a $(0.139 \mathrm{~g}, 0.50 \mathrm{mmol}), \mathrm{K}_{3} \mathrm{PO}_{4} \cdot \mathrm{H}_{2} \mathrm{O}(0.58 \mathrm{~g}, 2.5 \mathrm{mmol}), \mathrm{Pd}_{2}(\mathrm{dba})_{3}(4.6 \mathrm{mg}, 2$ mol\% Pd), S-Phos $(10.3 \mathrm{mg}, 5 \mathrm{~mol} \%)$ and $\mathrm{H}_{2} \mathrm{O}(10 \mu \mathrm{L})$ at $60{ }^{\circ} \mathrm{C}$ for $3 \mathrm{~h}$ to afford the titled product as an oil $(0.080 \mathrm{~g}, 79 \%)$ after purification by flash chromatography (5\%

\footnotetext{
${ }^{11}$ Sadanandan, E. V.; Srinivasan, P. C. Synthesis 1992, 648.
} 
EtOAc in hexanes). ${ }^{12}{ }^{1} \mathrm{H}$ NMR $\left(300 \mathrm{MHz}, \mathrm{CDCl}_{3}\right) \delta 7.74(1 \mathrm{H}, \mathrm{br}), 7.51(1 \mathrm{H}, \mathrm{d}, J=7.5$ $\mathrm{Hz}), 7.24(1 \mathrm{H}, \mathrm{d}, J=7.9 \mathrm{~Hz}), 7.11-7.01(2 \mathrm{H}, \mathrm{m}), 6.21(1 \mathrm{H}, \mathrm{d}, J=2.2 \mathrm{~Hz}), 2.72(2 \mathrm{H}, \mathrm{t}, J=$ 7.5), $1.68(2 \mathrm{H}$, quintet, $J=7.6), 1.40-1.25(6 \mathrm{H}, \mathrm{m}), 0.87(3 \mathrm{H}, \mathrm{t}, J=7.6 \mathrm{~Hz}) .{ }^{1} \mathrm{C}$ NMR $(75$ $\left.\mathrm{MHz}, \mathrm{CDCl}_{3}\right) \delta 140.2,136.0,129.1,121.1,119.9,119.7,110.5,99.6,31.9,29.4,29.2$, $28.5,22.8,14.3$.

\section{4-Methyl-2-phenyl-1H-indole (18a)}<smiles>Cc1cccc(N)c1C=C(Br)Br</smiles>

General procedure A for the Pd-catalyzed tandem coupling was followed. A mixture of 2-(2,2-dibromovinyl)-3-methylphenylamine (0.147 g, $0.53 \mathrm{mmol}), \mathrm{PhB}(\mathrm{OH})_{2}(0.092 \mathrm{~g}$, $0.75 \mathrm{mmol}), \mathrm{K}_{3} \mathrm{PO}_{4} \cdot \mathrm{H}_{2} \mathrm{O}(0.58 \mathrm{~g}, 2.5 \mathrm{mmol})$, and a catalyst solution $\left(\mathrm{Pd}(\mathrm{OAc})_{2}(5.6 \mathrm{mg}, 5\right.$ mol\%) and S-Phos $(20.5 \mathrm{mg}, 10 \mathrm{~mol} \%)$ in PhMe $(2.5 \mathrm{~mL})$ ) was heated at $90{ }^{\circ} \mathrm{C}$ for $2 \mathrm{~h}$. After an aqueous workup, the crude material was purified by flash chromatography (5\% EtOAc in hexanes) to afford a white crystalline solid $(0.080 \mathrm{~g}, 77 \%)$ as the title product. ${ }^{1} \mathrm{H}$ NMR $\left(300 \mathrm{MHz}, \mathrm{CDCl}_{3}\right) \delta 8.33(1 \mathrm{H}, \mathrm{br}), 7.67\left(2 \mathrm{H}, \mathrm{dm}, J^{\mathrm{d}}=7.2 \mathrm{~Hz}\right), 7.44\left(2 \mathrm{H}, \mathrm{tm}, J^{\mathrm{t}}\right.$ $=7.6 \mathrm{~Hz}), 7.31(1 \mathrm{H}, \mathrm{tt}, J=7.5,1.2 \mathrm{~Hz}), 7.24(1 \mathrm{H}, \mathrm{d}, J=8.1 \mathrm{~Hz}), 7.10(1 \mathrm{H}, \mathrm{t}, J=7.6 \mathrm{~Hz})$, $6.92\left(1 \mathrm{H}, \mathrm{dt}, J^{\mathrm{d}}=7.2 \mathrm{~Hz}, J^{\mathrm{t}}=0.8 \mathrm{~Hz}\right), 6.85(1 \mathrm{H}, \mathrm{dd}, J=2.2,1.0 \mathrm{~Hz}), 2.58(3 \mathrm{H}, \mathrm{s})$.

\section{4-Benzyloxy-5-methoxy-2-phenyl-1H-indole (18c)}<smiles>COc1ccc(N)c(C=C(Br)Br)c1OCc1ccccc1</smiles><smiles>COc1ccc2[nH]c(-c3ccccc3)cc2c1OCc1ccccc1</smiles>

General procedure A for the Pd-catalyzed tandem coupling was followed. A mixture of 3-benzyloxy-2-(2,2-dibromovinyl)-4-methoxyphenylamine $(0.124 \mathrm{~g}, 0.30 \mathrm{mmol})$, $\mathrm{PhB}(\mathrm{OH})_{2}(0.055 \mathrm{~g}, 0.45 \mathrm{mmol}), \mathrm{K}_{3} \mathrm{PO}_{4} \cdot \mathrm{H}_{2} \mathrm{O}(0.35 \mathrm{~g}, 1.5 \mathrm{mmol})$, and a catalyst solution

\footnotetext{
${ }^{12}$ Ishikura, M.; Agata, I. Heterocycles 1995, 41, 2437.
} 
$\left(\mathrm{Pd}(\mathrm{OAc})_{2}(2.2 \mathrm{mg}, 3 \mathrm{~mol} \%)\right.$ and $\mathrm{S}-\mathrm{Phos}(8.8 \mathrm{mg}, 6 \mathrm{~mol} \%)$ in $\left.\mathrm{PhMe}(1.5 \mathrm{~mL})\right)$ was heated at $100{ }^{\circ} \mathrm{C}$ for $2 \mathrm{~h}$. After an aqueous workup, the crude material was purified by flash chromatography (20\% EtOAc in hexanes) to afford an off-white crystalline solid (0.0713 g, 72\%). $\mathrm{R}_{\mathrm{f}}=0.18$ (2.5\% EtOAc in hexanes). mp 106-108 ${ }^{\circ} \mathrm{C}$. IR (neat, $\left.\mathrm{cm}^{-1}\right)$ : $3425,3353,2935,1504,1484,1456,1329,1237,1092 .{ }^{1} \mathrm{H}$ NMR $\left(400 \mathrm{MHz}, \mathrm{CDCl}_{3}\right) \delta$ $8.24(1 \mathrm{H}, \mathrm{br}), 7.57(2 \mathrm{H}, \mathrm{d}, J=7.7 \mathrm{~Hz}), 7.53(2 \mathrm{H}, \mathrm{d}, J=7.4 \mathrm{~Hz}), 7.40-7.34(4 \mathrm{H}, \mathrm{m}), 7.31$ $7.26(2 \mathrm{H}, \mathrm{m}), 7.01(1 \mathrm{H}, \mathrm{d}, J=8.8 \mathrm{~Hz}), 6.09(1 \mathrm{H}, \mathrm{d}, J=8.6 \mathrm{~Hz}), 6.80(1 \mathrm{H}, \mathrm{d}, J=1.3 \mathrm{~Hz})$, $5.26(2 \mathrm{H}, \mathrm{s}), 3.87(3 \mathrm{H}, \mathrm{s}) .{ }^{13} \mathrm{C} \mathrm{NMR}\left(100 \mathrm{MHz}, \mathrm{CDCl}_{3}\right) \delta 145.6,141.1,138.5,138.5$, 134.2, 132.4, 129.1, 128.5, 128.3, 128.0, 127.9, 125.3, 124.8, 112.3, 106.4, 97.5, 75.3, 58.5. HRMS (EI) calc'd for $\mathrm{C}_{22} \mathrm{H}_{19} \mathrm{NO}_{2}\left([\mathrm{M}]^{+}\right)$329.1416. Found: 329.1423 .

\section{5-Benzyloxy-2-phenyl-1H-indole (18d)}

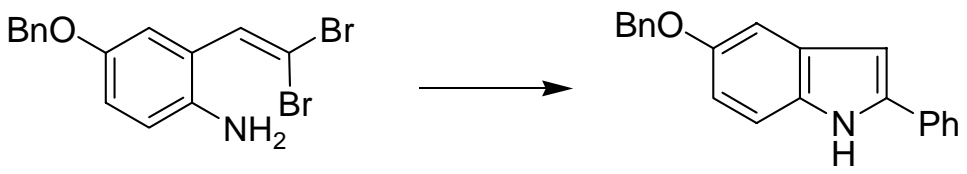

General procedure A for the Pd-catalyzed tandem coupling was followed. A mixture of 4-benzyloxy-2-(2,2-dibromovinyl)-phenylamine (0.193 g, $0.50 \mathrm{mmol}), \mathrm{PhB}(\mathrm{OH})_{2}$ (0.092 g, $0.75 \mathrm{mmol}), \mathrm{K}_{3} \mathrm{PO}_{4} \cdot \mathrm{H}_{2} \mathrm{O}(0.58 \mathrm{~g}, 2.5 \mathrm{mmol})$, and a catalyst solution $\left(\mathrm{Pd}(\mathrm{OAc})_{2}\right.$ (2.3 mg, $2 \mathrm{~mol} \%$ ) and S-Phos ( $8.2 \mathrm{mg}, 4 \mathrm{~mol} \%$ ) in PhMe $(2.5 \mathrm{~mL})$ ) was heated at $90{ }^{\circ} \mathrm{C}$ for $3 \mathrm{~h}$. After an aqueous workup, the crude material was purified by flash chromatography (15\% EtOAc in hexanes) to afford a white crystalline solid $(0.130 \mathrm{~g}$, $86 \%) . \mathrm{R}_{\mathrm{f}}=0.27$ (15\% EtOAc/Hexanes). mp 168-170 ${ }^{\circ} \mathrm{C}$. IR (neat, $\left.\mathrm{cm}^{-1}\right): 3441,1586$, 1449, 1409, 1214, 1154. ${ }^{1} \mathrm{H}$ NMR $\left(400 \mathrm{MHz}, \mathrm{CDCl}_{3}\right) \delta 8.20(1 \mathrm{H}, \mathrm{br}), 7.62(2 \mathrm{H}, \mathrm{d}, J=$ $7.8 \mathrm{~Hz}), 7.48(2 \mathrm{H}, \mathrm{d}, J=7.1 \mathrm{~Hz}), 7.41(2 \mathrm{H}, \mathrm{t}, J=7.7 \mathrm{~Hz}), 7.38(2 \mathrm{H}, \mathrm{t}, J=7.2 \mathrm{~Hz}), 7.31$ $(1 \mathrm{H}, \mathrm{t}, J=7.8 \mathrm{~Hz}), 7.30(1 \mathrm{H}, \mathrm{t}, J=8.0 \mathrm{~Hz}), 7.27(1 \mathrm{H}, \mathrm{d}, J=7.8 \mathrm{~Hz}), 7.16(1 \mathrm{H}, \mathrm{d}, J=2.2$ $\mathrm{Hz}), 6.93(1 \mathrm{H}, \mathrm{dd}, J=8.8,2.4 \mathrm{~Hz}), 6.73(1 \mathrm{H}, \mathrm{d}, J=2.0 \mathrm{~Hz}), 5.11(2 \mathrm{H}, \mathrm{s}) .{ }^{13} \mathrm{C}$ NMR $(100$ $\left.\mathrm{MHz}, \mathrm{CDCl}_{3}\right) \delta 153.9,138.8,137.9,132.6,132.4,129.9,129.2,128.7,128.0,127.9$, $127.8,125.3,113.5,111.8,104.1,100.1,71.0$. HRMS (ESI) calc'd for $\mathrm{C}_{21} \mathrm{H}_{18} \mathrm{NO}\left(\mathrm{M}+\mathrm{H}^{+}\right)$ 300.1382. Found: 300.1395. 


\section{5-Fluoro-2-phenyl-1H-indole (18e)}

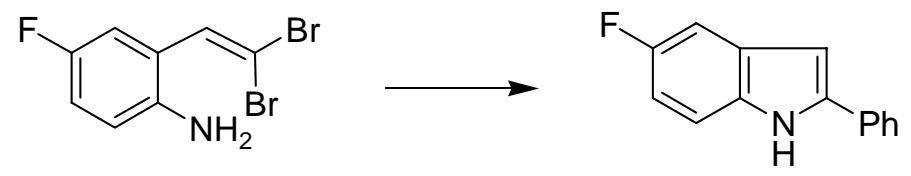

General procedure A for the Pd-catalyzed tandem coupling was followed. A mixture of 2-(2,2-dibromovinyl)-4-fluorophenylamine (0.150 g, $0.51 \mathrm{mmol}), \mathrm{PhB}(\mathrm{OH})_{2}(0.092 \mathrm{~g}$, $0.75 \mathrm{mmol}), \mathrm{K}_{3} \mathrm{PO}_{4} \cdot \mathrm{H}_{2} \mathrm{O}(0.58 \mathrm{~g}, 2.5 \mathrm{mmol})$, and a catalyst solution $\left(\mathrm{Pd}(\mathrm{OAc})_{2}(1.2 \mathrm{mg}, 1\right.$ $\mathrm{mol} \%$ ) and S-Phos (4.2 mg, $2 \mathrm{~mol} \%)$ in PhMe $(2.5 \mathrm{~mL})$ ) was heated at $90{ }^{\circ} \mathrm{C}$ for $2 \mathrm{~h}$. After an aqueous workup, the crude material was purified by flash chromatography $(10 \%$ EtOAc in hexanes) to afford a white crystalline solid (0.094 g, 87\%). ${ }^{13}{ }^{1} \mathrm{H}$ NMR (300 $\left.\mathrm{MHz} \mathrm{CDCl}_{3}\right) \delta 8.28(1 \mathrm{H}, \mathrm{br}), 7.63(2 \mathrm{H}, \mathrm{d}, J=7.4 \mathrm{~Hz}), 7.44(2 \mathrm{H}, \mathrm{t}, J=7.6 \mathrm{~Hz}), 7.33(1 \mathrm{H}$, t, $J=7.5 \mathrm{~Hz}), 7.29-7.25(2 \mathrm{H}, \mathrm{m}), 6.93(1 \mathrm{H}, \mathrm{ddd}, J=9.1,9.1,2.5 \mathrm{~Hz}), 6.77(1 \mathrm{H}, \mathrm{d}, J=1.3$ $\mathrm{Hz}) .{ }^{19} \mathrm{~F} \mathrm{NMR}\left(282 \mathrm{MHz}, \mathrm{CDCl}_{3}\right) \delta-124.6$.

\section{2-Phenyl-1H-indole-5-carboxylic acid methyl ester (18f)}

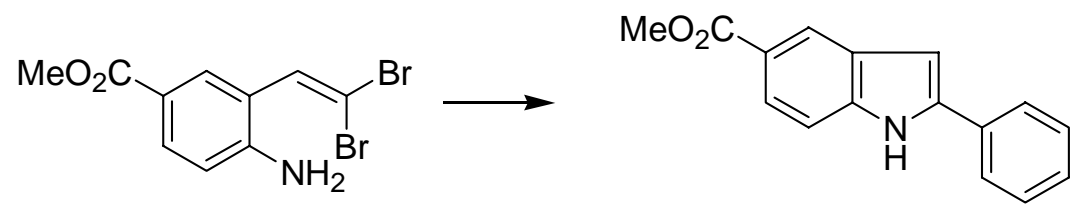

General procedure A for the Pd-catalyzed tandem coupling was followed. A mixture of 4-amino-3-(2,2-dibromovinyl)-benzoic acid methyl ester (0.100 g, $0.30 \mathrm{mmol})$, $\mathrm{PhB}(\mathrm{OH})_{2}(0.055 \mathrm{~g}, 0.45 \mathrm{mmol}), \mathrm{K}_{3} \mathrm{PO}_{4} \cdot \mathrm{H} 2 \mathrm{O}(0.35 \mathrm{~g}, 1.5 \mathrm{mmol})$, and a catalyst solution $\left(\mathrm{Pd}(\mathrm{OAc})_{2}(2.2 \mathrm{mg}, 3 \mathrm{~mol} \%)\right.$ and $\mathrm{S}-\mathrm{Phos}(8.1 \mathrm{mg}, 6 \mathrm{~mol} \%)$ in $\left.\mathrm{PhMe}(1.5 \mathrm{~mL})\right)$ was heated at $100{ }^{\circ} \mathrm{C}$ for $1.5 \mathrm{~h}$. After an aqueous workup, the crude material was purified by flash chromatography (20\% EtOAc in hexanes) to afford a white crystalline solid (0.066 g, 87\%). ${ }^{14}{ }^{1} \mathrm{H}$ NMR (300 MHz, DMSO-d $) \delta 11.94(1 \mathrm{H}, \mathrm{s}), 8.25(1 \mathrm{H}, \mathrm{s}), 7.88(2 \mathrm{H}, \mathrm{d}, J=$ $7.5 \mathrm{~Hz}), 7.75(1 \mathrm{H}, \mathrm{d}, J=8.3 \mathrm{~Hz}), 7.50-7.48(2 \mathrm{H}, \mathrm{m}), 7.37-7.34(1 \mathrm{H}, \mathrm{m}), 7.06(1 \mathrm{H}, \mathrm{s})$,

\footnotetext{
${ }^{13}$ Rowley, M.; Hallett, D. J.; Goodacre, S.; Moyes, C.; Crawforth, J.; Sparey, T. J.; Patel, S.; Marwood, R.; Patel, S.; Thomas, S.; Hitzel, L.; O'Connor, D.; Szeto, N.; Castro, J. L.; Hutson, P. H.; MacLeod, A. M. J. Med. Chem. 2001, 44, 1603.

${ }^{14}$ Fagnola, M. C.; Candiani, I.; Visentin, G.; Cabri, W.; Zarini, F.; Mongelli, N.; Bedeschi, A. Tetrahedron Lett. 1997, 38, 2307.
} 
$3.85(3 \mathrm{H}, \mathrm{s}) .{ }^{13} \mathrm{C}$ NMR $(75 \mathrm{MHz}$, DMSO-d 6 ) $\delta 167.2,139.7,139.5,131.6,129.0,128.2$, $127.9,125.2,122.6,122.5,120.9,111.2,99.9,51.7$.

\section{5,6-Bisbenzyloxy-2-phenyl-1H-indole (18g)}

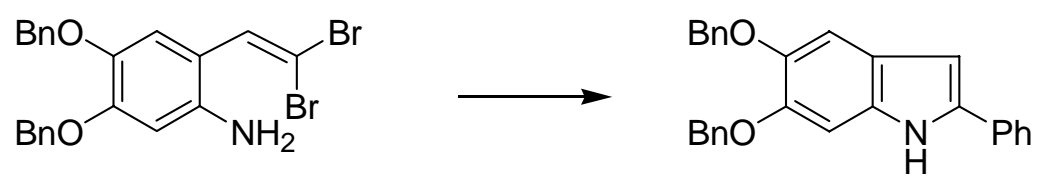

General procedure A for the Pd-catalyzed tandem coupling was followed. A mixture of 2-(2,2-dibromovinyl)-4,5-dimethoxy-phenylamine (0.147 g, $0.30 \mathrm{mmol}), \mathrm{PhB}(\mathrm{OH})_{2}$ (0.055 g, $0.45 \mathrm{mmol}), \mathrm{K}_{3} \mathrm{PO}_{4} \cdot \mathrm{H}_{2} \mathrm{O}(0.35 \mathrm{~g}, 1.5 \mathrm{mmol})$, and a catalyst solution $\left(\mathrm{Pd}(\mathrm{OAc})_{2}\right.$ (2.3 mg, $3.3 \mathrm{~mol} \%)$ and S-Phos ( $8.2 \mathrm{mg}, 6.6 \mathrm{~mol} \%)$ in PhMe (1.5 mL)) was heated at 90 ${ }^{\circ} \mathrm{C}$ for $4.5 \mathrm{~h}$. After an aqueous workup, the crude material was purified by flash chromatography $(10 \% \rightarrow 15 \% \rightarrow 20 \%$ EtOAc in hexanes) to afford a white crystalline solid $(0.069 \mathrm{~g}, 57 \%) . \mathrm{R}_{\mathrm{f}}=0.20\left(20 \%\right.$ EtOAc/Hexanes). $\mathrm{mp} 140-141{ }^{\circ} \mathrm{C}$. IR (neat, $\left.\mathrm{cm}^{-1}\right): 3396$, $1602,1450,1337,1300,1243,1206,1132 .{ }^{1} \mathrm{H}$ NMR $\left(300 \mathrm{MHz}, \mathrm{CDCl}_{3}\right) \delta 8.18(1 \mathrm{H}, \mathrm{br})$, $7.54(2 \mathrm{H}, \mathrm{d}, J=7.4 \mathrm{~Hz}), 7.50-7.24(13 \mathrm{H}, \mathrm{m}), 7.16(1 \mathrm{H}, \mathrm{s}), 6.90(1 \mathrm{H}, \mathrm{s}), 6.66(1 \mathrm{H}, \mathrm{s}), 5.17$ $(2 \mathrm{H}, \mathrm{s}), 5.14(2 \mathrm{H}, \mathrm{s}) .{ }^{13} \mathrm{C} \mathrm{NMR}\left(75 \mathrm{MHz}, \mathrm{CDCl}_{3}\right) \delta 147.3,145.3,138.0,137.7,137.3$, 132.7, 132.1, 129.1, 128.7, 128.6, 127.9, 127.9, 127.7, 127.6, 127.4, 124.9, 123.2, 106.8, 99.9, 98.3, 72.5, 72.1. Anal. Calc'd for $\mathrm{C}_{28} \mathrm{H}_{23} \mathrm{NO}_{2}$ : C, 82.94; H, 5.72; N, 3.45. Found: C, $82.62 ; \mathrm{H}, 6.05 ; \mathrm{N}, 3.49$.

\section{2-Phenyl-1H-indole-6-carboxylic acid methyl ester (18h)}<smiles>CC(=O)c1ccc(C=C(Br)Br)c(N)c1</smiles>

General procedure A for the Pd-catalyzed tandem coupling was followed. A mixture of 3-amino-4-(2,2-dibromovinyl)-benzoic acid methyl ester (0.168 g, $0.50 \mathrm{mmol})$, $\mathrm{PhB}(\mathrm{OH})_{2}(0.092 \mathrm{~g}, 0.75 \mathrm{mmol}), \mathrm{K}_{3} \mathrm{PO}_{4} \cdot \mathrm{H}_{2} \mathrm{O}(0.58 \mathrm{~g}, 2.5 \mathrm{mmol})$, and a catalyst solution $\left(\mathrm{Pd}(\mathrm{OAc})_{2}(1.2 \mathrm{mg}, 1 \mathrm{~mol} \%)\right.$ and S-Phos $(4.1 \mathrm{mg}, 2 \mathrm{~mol} \%)$ in $\left.\mathrm{PhMe}(2.5 \mathrm{~mL})\right)$ was heated at $90{ }^{\circ} \mathrm{C}$ for $8.5 \mathrm{~h}$. After an aqueous workup, the crude material was purified by 
flash chromatography $(10 \% \rightarrow 20 \%$ EtOAc in hexanes $)$ to afford a white crystalline solid $(0.113 \mathrm{~g}, 90 \%) . \mathrm{R}_{\mathrm{f}}=0.23$ (20\% EtOAc/Hexanes). $\mathrm{mp} 208-210^{\circ} \mathrm{C}$. IR (neat, $\left.\mathrm{cm}^{-1}\right): 3347$, 1694, 1620, 1504, 1435, 1317, 1284, 1232. ${ }^{1} \mathrm{H}$ NMR (300 MHz, DMSO-d $) \delta 11.95(1 \mathrm{H}$, s), $8.06(1 \mathrm{H}, \mathrm{s}), 7.91(2 \mathrm{H}, \mathrm{d}, J=8.2 \mathrm{~Hz}), 7.63(2 \mathrm{H}, \mathrm{s}), 7.51(2 \mathrm{H}, \mathrm{t}, J=7.6 \mathrm{~Hz}), 7.38(1 \mathrm{H}$, t, $J=7.0 \mathrm{~Hz}), 7.02(1 \mathrm{H}, \mathrm{s}), 3.86(3 \mathrm{H}, \mathrm{s}) .{ }^{13} \mathrm{C}$ NMR $\left(75 \mathrm{MHz}, \mathrm{DMSO}-\mathrm{d}_{6}\right) \delta 167.2,141.4$, $136.3,132.4,131.5,129.1,128.3,125.5,122.4,120.2,119.8,113.1,99.2,51.9$. Anal. Calc'd for $\mathrm{C}_{16} \mathrm{H}_{13} \mathrm{NO}_{2}$ : C, 76.48; H, 5.21; N, 5.57. Found: C, 76.49; H, 5.41; N, 5.62. HRMS calc'd for $\mathrm{C}_{16} \mathrm{H}_{13} \mathrm{NO}_{2}\left(\mathrm{M}+\mathrm{H}^{+}\right)$251.0946. Found: 251.0943 .

\section{6-Fluoro-2-phenyl-1H-indole (18i)}

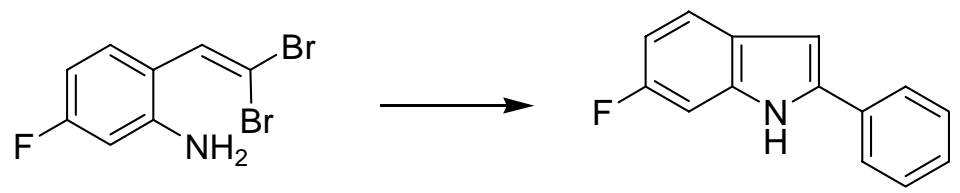

General procedure A for the Pd-catalyzed tandem coupling was followed. A mixture of 2-(2,2-dibromovinyl)-5-fluoro-phenylamine (0.148 g, $0.50 \mathrm{mmol}), \mathrm{PhB}(\mathrm{OH})_{2}(0.092 \mathrm{~g}$, $0.75 \mathrm{mmol}), \mathrm{K}_{3} \mathrm{PO}_{4} \cdot \mathrm{H}_{2} \mathrm{O}(0.58 \mathrm{~g}, 2.5 \mathrm{mmol})$, and a catalyst solution $\left(\mathrm{Pd}(\mathrm{OAc})_{2}(2.3 \mathrm{mg}, 2\right.$ $\mathrm{mol} \%$ ) and S-Phos $(8.2 \mathrm{mg}, 4 \mathrm{~mol} \%)$ in PhMe $(2.5 \mathrm{~mL}))$ was heated at $90{ }^{\circ} \mathrm{C}$ for $2.5 \mathrm{~h}$. After an aqueous workup, the crude material was purified by flash chromatography $(5 \%$ EtOAc in hexanes) to afford a white crystalline solid $(0.085 \mathrm{~g}, 80 \%) .{ }^{13}{ }^{1} \mathrm{H}$ NMR (300 $\left.\mathrm{MHz} \mathrm{CDCl}_{3}\right) \delta 8.31(1 \mathrm{H}, \mathrm{br}), 7.61(2 \mathrm{H}, \mathrm{d}, J=7.7 \mathrm{~Hz}), 7.52(1 \mathrm{H}, \mathrm{dd}, J=8.8,5.5 \mathrm{~Hz})$, $7.43(2 \mathrm{H}, \mathrm{t}, J=7.6 \mathrm{~Hz}), 7.31(1 \mathrm{H}, \mathrm{t}, J=7.3 \mathrm{~Hz}), 7.06(1 \mathrm{H}, \mathrm{dd}, J=9.3,1.6 \mathrm{~Hz}), 6.89(1 \mathrm{H}$, ddd, $J=9.2,9.2,2.2 \mathrm{~Hz}), 6.78(1 \mathrm{H}, \mathrm{d}, J=1.5 \mathrm{~Hz})$.

\section{6-Benzyloxy-2-phenyl-1H-indole (18j)}

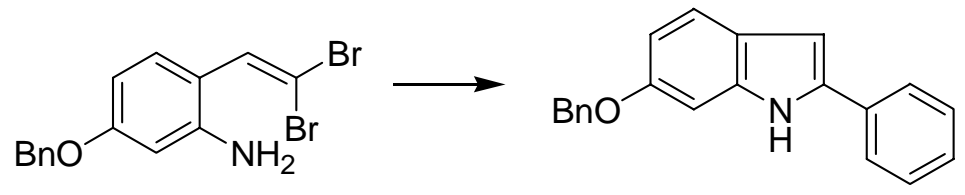

General procedure A for the Pd-catalyzed tandem coupling was followed. A mixture of 5-benzyloxy-2-(2,2-dibromovinyl)-phenylamine (0.115 g, $0.30 \mathrm{mmol}), \mathrm{PhB}(\mathrm{OH})_{2}$ 
(0.055 g, $0.45 \mathrm{mmol}), \mathrm{K}_{3} \mathrm{PO}_{4} \cdot \mathrm{H}_{2} \mathrm{O}(0.35 \mathrm{~g}, 1.5 \mathrm{mmol})$, and a catalyst solution ( $\mathrm{Pd}(\mathrm{OAc})_{2}$ (3.4 mg, $5 \mathrm{~mol} \%$ ) and S-Phos (12.3 mg, $10 \mathrm{~mol} \%$ ) in PhMe (1.5 mL)) was heated at 100 ${ }^{\circ} \mathrm{C}$ for $1.5 \mathrm{~h}$. After an aqueous workup, the crude material was purified by flash chromatography (20\% EtOAc in hexanes) to afford an off-white crystalline solid (0.066 g, 73\%). $\mathrm{R}_{\mathrm{f}}=0.25$ (2.5\% EtOAc in hexanes). mp 200-202 ${ }^{\circ} \mathrm{C}$ (Lit: 202-204 $\left.{ }^{\circ} \mathrm{C}\right) .{ }^{15}{ }^{1} \mathrm{H}$ NMR (400 MHz, $\left.\mathrm{CDCl}_{3}\right) \delta 8.20(1 \mathrm{H}, \mathrm{br}), 7.62-7.60(2 \mathrm{H}, \mathrm{m}), 7.51-7.27(9 \mathrm{H}, \mathrm{m}), 6.95$ $(1 \mathrm{H}, \mathrm{d}, J=2.2 \mathrm{~Hz}), 6.88(1 \mathrm{H}, \mathrm{dd}, J=8.6,1.2 \mathrm{~Hz}), 6.75(1 \mathrm{H}, \mathrm{d}, J=1.3 \mathrm{~Hz}), 5.13(2 \mathrm{H}, \mathrm{s})$.

\section{2-Phenyl-6-trifluoromethyl-1H-indole (18k)}<smiles>Nc1cc(C(F)(F)F)ccc1C=C(Br)Br</smiles>

General procedure A for the Pd-catalyzed tandem coupling was followed. A mixture of 2-(2,2-dibromovinyl)-5-trifluoromethyl-phenylamine (0.172 g, $0.50 \mathrm{mmol}), \mathrm{PhB}(\mathrm{OH})_{2}$ (0.092 g, $0.75 \mathrm{mmol}), \mathrm{K}_{3} \mathrm{PO}_{4} \cdot \mathrm{H}_{2} \mathrm{O}(0.58 \mathrm{~g}, 2.5 \mathrm{mmol})$, and a catalyst solution ( $\mathrm{Pd}(\mathrm{OAc})_{2}$ $(1.2 \mathrm{mg}, 1 \mathrm{~mol} \%)$ and S-Phos (4.1 mg, $2 \mathrm{~mol} \%)$ in PhMe $(2.5 \mathrm{~mL})$ ) was heated at $90{ }^{\circ} \mathrm{C}$ for $2.5 \mathrm{~h}$. After an aqueous workup, the crude material was purified by flash chromatography (5\% EtOAc in hexanes) to afford a white crystalline solid $(0.118 \mathrm{~g}$, 90\%). ${ }^{1} \mathrm{H}$ NMR (300 MHz, $\left.\mathrm{CDCl}_{3}\right) \delta 8.55(1 \mathrm{H}, \mathrm{br}), 7.70-7.66(4 \mathrm{H}, \mathrm{m}), 7.47(2 \mathrm{H}, \mathrm{t}, J=$ $7.7 \mathrm{~Hz}), 7.40-7.34(2 \mathrm{H}, \mathrm{m}), 6.86(1 \mathrm{H}, \mathrm{d}, J=1.9 \mathrm{~Hz}) .{ }^{19} \mathrm{~F} \mathrm{NMR}\left(211 \mathrm{MHz}, \mathrm{CDCl}_{3}\right) \delta$ 60.5 .

\section{7-Methyl-2-phenyl-1H-indole (18l)}

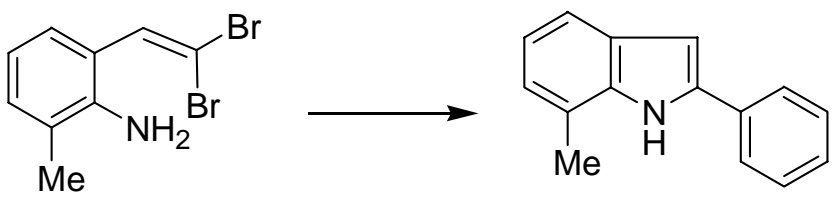

General procedure A for the Pd-catalyzed tandem coupling was followed. A mixture of 2-(2,2-dibromovinyl)-6-methyl-phenylamine $(0.087 \mathrm{~g}, 0.30 \mathrm{mmol}), \mathrm{PhB}(\mathrm{OH})_{2}(0.055$

\footnotetext{
${ }^{15}$ Izumi, T.; Yokota, T. J. Heterocycl. Chem. 1992, 29, 1085.
} 
g, $0.45 \mathrm{mmol}), \mathrm{K}_{3} \mathrm{PO}_{4} \cdot \mathrm{H}_{2} \mathrm{O}(0.35 \mathrm{~g}, 1.5 \mathrm{mmol})$, and a catalyst solution $\left(\mathrm{Pd}(\mathrm{OAc})_{2}(2.2\right.$ $\mathrm{mg}, 3 \mathrm{~mol} \%$ ) and S-Phos (8.1 mg, $6 \mathrm{~mol} \%)$ in PhMe $(1.5 \mathrm{~mL}))$ was heated at $100{ }^{\circ} \mathrm{C}$ for 2 h. After an aqueous workup, the crude material was purified by flash chromatography (7.5\% EtOAc in hexanes) to afford a white crystalline solid $(0.0553 \mathrm{~g}, 89 \%) .{ }^{16}{ }^{1} \mathrm{H}$ NMR $\left(300 \mathrm{MHz}, \mathrm{CDCl}_{3}\right) \delta 8.18(1 \mathrm{H}, \mathrm{br}), 7.68(2 \mathrm{H}, \mathrm{d}, J=8.0 \mathrm{~Hz}), 7.53-7.42(3 \mathrm{H}, \mathrm{m}), 7.32(1 \mathrm{H}$, $\left.\mathrm{tm}, J^{\mathrm{d}}=7.3 \mathrm{~Hz}\right), 7.07-6.98(2 \mathrm{H}, \mathrm{m}), 6.83(1 \mathrm{H}, \mathrm{d}, J=2.2 \mathrm{~Hz}), 2.54(3 \mathrm{H}, \mathrm{s})$.

\section{2-Phenyl-1H-benzo[g]indole (18m)}

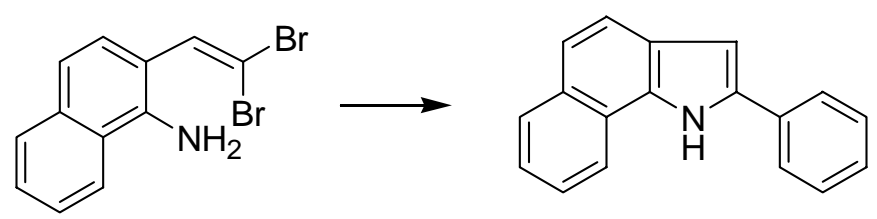

General procedure A for the Pd-catalyzed tandem coupling was followed. A mixture of 2-(2,2-dibromovinyl)-naphthalen-1-ylamine (0.098 g, $0.30 \mathrm{mmol}), \mathrm{PhB}(\mathrm{OH})_{2}(0.055 \mathrm{~g}$, $0.45 \mathrm{mmol}), \mathrm{K}_{3} \mathrm{PO}_{4} \cdot \mathrm{H}_{2} \mathrm{O}(0.35 \mathrm{~g}, 1.5 \mathrm{mmol})$, and a catalyst solution $\left(\mathrm{Pd}(\mathrm{OAc})_{2}(2.2 \mathrm{mg}, 3\right.$ $\mathrm{mol} \%$ ) and S-Phos $(8.1 \mathrm{mg}, 6 \mathrm{~mol} \%)$ in PhMe $(1.5 \mathrm{~mL}))$ was heated at $100{ }^{\circ} \mathrm{C}$ for $2 \mathrm{~h}$. After an aqueous workup, the crude material was purified by flash chromatography $(7.5 \%$ EtOAc in hexanes) to afford a slightly yellow crystalline solid (0.0564 g, 77\%). ${ }^{1} \mathrm{H}$ NMR $\left(300 \mathrm{MHz}, \mathrm{CDCl}_{3}\right) \delta 9.52(1 \mathrm{H}, \mathrm{br}), 8.07(1 \mathrm{H}, \mathrm{d}, J=7.6 \mathrm{~Hz}), 7.92(1 \mathrm{H}, \mathrm{d}, J=8.0 \mathrm{~Hz})$, 7.75-7.70 (3H, m), 7.58-7.41 $(5 \mathrm{H}, \mathrm{m}), 7.35\left(1 \mathrm{H}, \mathrm{tm}, J^{\mathrm{d}}=7.4 \mathrm{~Hz}\right), 6.96(1 \mathrm{H}, \mathrm{d}, J=2.2$ $\mathrm{Hz})$.

\section{2-Phenyl-3-trifluoromethyl-1H-indole (19a)}<smiles>Nc1ccccc1C(=C(Br)Br)C(F)(F)F</smiles>

General procedure A for the Pd-catalyzed tandem coupling was followed. A mixture of 2-(2,2-dibromo-1-trifluoromethylvinyl)-phenylamine (0.103 g, $0.30 \mathrm{mmol}), \mathrm{PhB}(\mathrm{OH})_{2}$

\footnotetext{
16 Junjappa, H. Synthesis 1975, 798.
} 
(0.055 g, $0.45 \mathrm{mmol}), \mathrm{K}_{3} \mathrm{PO}_{4} \cdot \mathrm{H}_{2} \mathrm{O}(0.35 \mathrm{~g}, 1.5 \mathrm{mmol})$, and a catalyst solution $\left(\mathrm{Pd}(\mathrm{OAc})_{2}\right.$ (2.2 mg, $3 \mathrm{~mol} \%$ ) and S-Phos ( $8.1 \mathrm{mg}, 6 \mathrm{~mol} \%)$ in PhMe $(1.5 \mathrm{~mL})$ ) was heated at $100{ }^{\circ} \mathrm{C}$ for $1 \mathrm{~h}$. After an aqueous workup, the crude material was purified by flash chromatography ( $15 \%$ EtOAc in hexanes) to afford a yellowish crystalline solid (0.062 g, 79\%). ${ }^{17} \mathrm{H}$ NMR (400 MHz, $\left.\mathrm{CDCl}_{3}\right) \delta 8.32(1 \mathrm{H}, \mathrm{br}), 7.82(1 \mathrm{H}, \mathrm{d}, J=7.5 \mathrm{~Hz}), 7.59-7.58$ $(2 \mathrm{H}, \mathrm{m}), 7.48-7.46(3 \mathrm{H}, \mathrm{m}), 7.39(1 \mathrm{H}, \mathrm{d}, J=7.5 \mathrm{~Hz}), 7.30-7.23(2 \mathrm{H}, \mathrm{m}) .{ }^{19} \mathrm{~F}$ NMR $(376$ $\left.\mathrm{MHz}, \mathrm{CDCl}_{3}\right) \delta-52.9$.

\section{2-Phenyl-3-phenylethynyl-1H-indole (19b)}

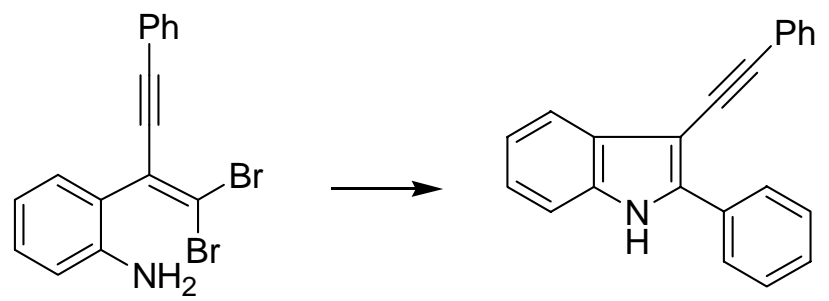

General procedure A for the Pd-catalyzed tandem coupling was followed. A mixture of 2-(1-dibromomethylene-3-phenyl-prop-2-ynyl)-phenylamine (0.113 g, $0.30 \mathrm{mmol})$, $\mathrm{PhB}(\mathrm{OH})_{2}(0.055 \mathrm{~g}, 0.45 \mathrm{mmol}), \mathrm{K}_{3} \mathrm{PO}_{4} \cdot \mathrm{H}_{2} \mathrm{O}(0.35 \mathrm{~g}, 1.5 \mathrm{mmol})$, and a catalyst solution $\left(\mathrm{Pd}(\mathrm{OAc})_{2}(2.2 \mathrm{mg}, 3 \mathrm{~mol} \%)\right.$ and $\mathrm{S}-\mathrm{Phos}(8.1 \mathrm{mg}, 6 \mathrm{~mol} \%)$ in $\left.\mathrm{PhMe}(1.5 \mathrm{~mL})\right)$ was heated at $100{ }^{\circ} \mathrm{C}$ for $2 \mathrm{~h}$. After an aqueous workup, the crude material was purified by flash chromatography (10\% EtOAc in hexanes) to afford the titled prodict as a white crystalline solid (0.068 g, 77\%). ${ }^{1} \mathrm{H}$ NMR (300 MHz, $\left.\mathrm{CDCl}_{3}\right) \delta 8.31(1 \mathrm{H}, \mathrm{br}), 8.02(2 \mathrm{H}$, d, $J=7.3 \mathrm{~Hz}), 7.85-7.82(1 \mathrm{H}, \mathrm{m}), 7.56(2 \mathrm{H}, \mathrm{dd}, J=8.0,1.5 \mathrm{~Hz}), 7.49(2 \mathrm{H}, \mathrm{t}, J=7.7 \mathrm{~Hz})$, 7.40-7.20 (7H, m).

\section{2-phenylindole (17a)}

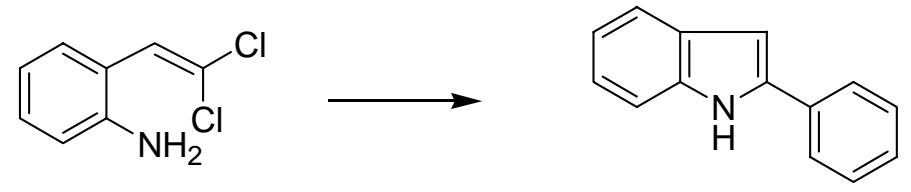

General procedure A for the Pd-catalyzed tandem coupling was followed. A mixture of 2-(2,2-dichlorovinyl)-phenylamine (0.094 g, $0.50 \mathrm{mmol}), \mathrm{PhB}(\mathrm{OH})_{2}(0.092 \mathrm{~g}, 0.75$

\footnotetext{
${ }^{17}$ Mikami, K.; Matsumoto, Y.; Shiono, T. Science of Synthesis 2003, 2, 457.
} 
$\mathrm{mmol}), \mathrm{K}_{3} \mathrm{PO}_{4} \cdot \mathrm{H}_{2} \mathrm{O}(0.58 \mathrm{~g}, 2.5 \mathrm{mmol})$, and a catalyst solution $\left(\mathrm{Pd}(\mathrm{OAc})_{2}(5.6 \mathrm{mg}, 5\right.$ $\mathrm{mol} \%$ ) and S-Phos (20.5 mg, $10 \mathrm{~mol} \%)$ in PhMe $(2.5 \mathrm{~mL})$ ) was heated at $90{ }^{\circ} \mathrm{C}$ for $2 \mathrm{~h}$. After an aqueous workup, the crude material was purified by flash chromatography $(10 \%$ EtOAc in hexanes) to afford a white crystalline solid $(0.093 \mathrm{~g}, 95 \%)$. ${ }^{1} \mathrm{H}$ NMR was identical to the authetic sample.

\section{2-Phenyl-3-methyl-1H-indole (19d)}<smiles>CC(=C(Cl)Cl)c1ccccc1N</smiles>

General procedure A for the Pd-catalyzed tandem coupling was followed. A mixture of 2-(2,2-dichloro-1-methylvinyl)-phenylamine (0.101 g, $0.50 \mathrm{mmol}), \mathrm{PhB}(\mathrm{OH})_{2}(0.092$ g, $0.75 \mathrm{mmol}), \mathrm{K}_{3} \mathrm{PO}_{4} \cdot \mathrm{H}_{2} \mathrm{O}(0.58 \mathrm{~g}, 2.5 \mathrm{mmol})$, and a catalyst solution $\left(\mathrm{Pd}(\mathrm{OAc})_{2}(2.2\right.$ $\mathrm{mg}, 2 \mathrm{~mol} \%$ ) and S-Phos (8.1 mg, $4 \mathrm{~mol} \%)$ in PhMe $(2.5 \mathrm{~mL})$ ) was heated at $100{ }^{\circ} \mathrm{C}$ for 2 h. After an aqueous workup, the crude material was purified by flash chromatography (10\% EtOAc in hexanes) to afford a white crystalline solid $(0.099 \mathrm{~g}, 96 \%) .{ }^{15} \mathrm{H} \mathrm{NMR}$ $\left(300 \mathrm{MHz}, \mathrm{CDCl}_{3}\right) \delta 7.98(1 \mathrm{H}, \mathrm{br}), 7.65(1 \mathrm{H}, \mathrm{d}, J=7.6 \mathrm{~Hz}), 7.60(2 \mathrm{H}, \mathrm{d}, J=7.4 \mathrm{~Hz})$, $7.51(2 \mathrm{H}, \mathrm{t}, J=7.6 \mathrm{~Hz}), 7.41-7.36(2 \mathrm{H}, \mathrm{m}), 7.25(1 \mathrm{H}, \mathrm{ddd}, J=7.3,7.3,1.3 \mathrm{~Hz}), 7.19(1 \mathrm{H}$, ddd, 7.2, 7.2, $1.1 \mathrm{~Hz}), 2.50(3 \mathrm{H}, \mathrm{s})$.

\section{Synthesis of 1,2-Disubstituted and 1,2,3-trisubstituted Indoles via Pd-Catalyzed Tandem C-N/C-C Couplings}



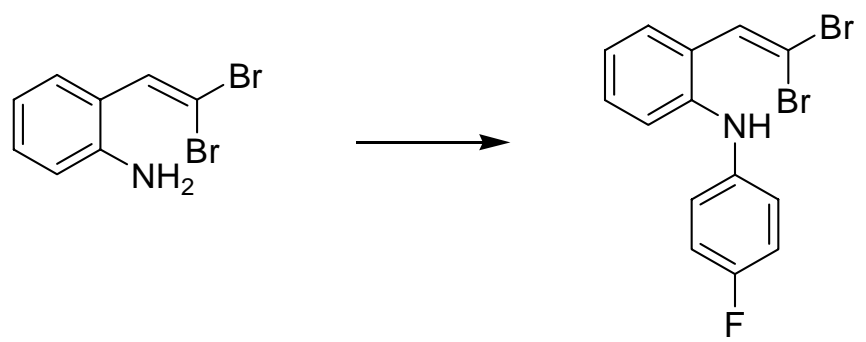

The general procedure for $\mathrm{Cu}(\mathrm{OAc})_{2}$-mediated coupling was followed using 1a (0.277 g, $1 \mathrm{mmol})$, 4-fluorophenylboronic acid (0.280 g, $2 \mathrm{mmol}), \mathrm{Cu}(\mathrm{OAc})_{2}(0.182 \mathrm{~g}, 1$ mmol), myristic acid (0.092 g, $0.4 \mathrm{mmol})$ and 2,6-lutidine $(125 \mu \mathrm{L}, 1.07 \mathrm{mmol})$ in toluene $(3 \mathrm{~mL})$. The mixture was stirred at $40{ }^{\circ} \mathrm{C}$ for $21 \mathrm{~h}$ and at $60{ }^{\circ} \mathrm{C}$ for $6 \mathrm{~h}$ under an $\mathrm{O}_{2}$ atmosphere. The product was further purified by flash chromatography $(2.5 \%$ EtOAc in hexanes) to afford the desired product as a solid $(0.268 \mathrm{~g}, 72 \%)$. $\mathrm{R}_{\mathrm{f}}=0.27$ (5\% EtOAc in hexanes). mp 75-77 ${ }^{\circ} \mathrm{C}$. IR (neat, $\mathrm{cm}^{-1}$ ): 3407, 3035, 1597, 1577, 1506, 1455, 1311, 1214. ${ }^{1} \mathrm{H}$ NMR $\left(400 \mathrm{MHz}, \mathrm{CDCl}_{3}\right) \delta 7.46(1 \mathrm{H}, \mathrm{d}, J=7.7 \mathrm{~Hz}), 7.38(1 \mathrm{H}, \mathrm{s}), 7.23(1 \mathrm{H}, \mathrm{ddd}, J=$ 8.0, 8.0, 1.1 Hz), $7.10(1 \mathrm{H}, \mathrm{d}, J=8.1 \mathrm{~Hz}), 7.01-6.99(4 \mathrm{H}, \mathrm{m}), 6.95(1 \mathrm{H}, \mathrm{t}, J=7.8 \mathrm{~Hz})$, $5.38(1 \mathrm{H}, \mathrm{s}) .{ }^{13} \mathrm{C}$ NMR $\left(100 \mathrm{MHz}, \mathrm{CDCl}_{3}\right) \delta 158.6\left(J_{\mathrm{C}-\mathrm{F}}=241 \mathrm{~Hz}\right), 141.7,138.8\left(J_{\mathrm{C}-\mathrm{F}}=\right.$ $2.3 \mathrm{~Hz}), 134.2,129.9,129.8,125.6,121.5\left(J_{\mathrm{C}-\mathrm{F}}=8.4 \mathrm{~Hz}\right), 120.9,116.9,116.2\left(J_{\mathrm{C}-\mathrm{F}}=22.2\right.$ $\mathrm{Hz})$, 93.3. ${ }^{19} \mathrm{~F}$ NMR $\left(282 \mathrm{MHz}, \mathrm{CDCl}_{3}\right) \delta$-121.1. HRMS (EI) calc'd for $\mathrm{C}_{14} \mathrm{H}_{10} \mathrm{NFBr}_{2}$ $\left([\mathrm{M}]^{+}\right)$368.9164. Found: 368.9175.

\section{[2-(2,2-Dibromovinyl)phenyl]-(3,4-dimethoxyphenyl)amine (24c)}<smiles>Nc1ccccc1C=C(Br)Br</smiles><smiles>COc1ccc(Nc2ccccc2C=C(Br)Br)cc1OC</smiles>

The general procedure for $\mathrm{Cu}(\mathrm{OAc})_{2}$-mediated coupling was followed using 1a (0.281 g, $1.01 \mathrm{mmol}), 3,4$-dimethoxyphenylboronic acid $(0.364 \mathrm{~g}, 2 \mathrm{mmol}), \mathrm{Cu}(\mathrm{OAc})_{2}$ $(0.182 \mathrm{~g}, 1 \mathrm{mmol})$, myristic acid $(0.092 \mathrm{~g}, 0.4 \mathrm{mmol})$ and 2,6-lutidine $(125 \mu \mathrm{L}, 1.07$ mmol) in toluene $(3 \mathrm{~mL})$. The mixture was stirred at $40{ }^{\circ} \mathrm{C}$ for $21 \mathrm{~h}$ under an $\mathrm{O}_{2}$ atmosphere. The crude material was further purified by flash chromatography ( $15 \%$ 
EtOAc in hexanes) to afford the desired product as a solid $(0.233 \mathrm{~g}, 56 \%) . \mathrm{R}_{\mathrm{f}}=0.20$ (20\% EtOAc in hexanes). $\mathrm{mp} 83-85^{\circ} \mathrm{C}$. IR (neat, $\mathrm{cm}^{-1}$ ): 3354, 2932, 1597, 1513, 1454, 1253, 1231, 1026. ${ }^{1} \mathrm{H}$ NMR $\left(300 \mathrm{MHz}, \mathrm{CDCl}_{3}\right) \delta 7.44(1 \mathrm{H}, \mathrm{d}, J=7.8 \mathrm{~Hz}), 7.39(1 \mathrm{H}, \mathrm{s})$, 7.20 (1H, ddd, $J=7.8,7.8,1.3 \mathrm{~Hz}), 7.07$ (1H, dd, $J=8.3,0.9 \mathrm{~Hz}), 6.89$ (1H, ddd, $J=7.4$, 7.4, $1.1 \mathrm{~Hz}), 6.81(1 \mathrm{H}, \mathrm{d}, J=8.2 \mathrm{~Hz}), 6.66-6.61(2 \mathrm{H}, \mathrm{m}), 5.37(1 \mathrm{H}, \mathrm{s}), 3.86(3 \mathrm{H}, \mathrm{s}), 3.82$ $(3 \mathrm{H}, \mathrm{s}) .{ }^{13} \mathrm{C}$ NMR $\left(75 \mathrm{MHz}, \mathrm{CDCl}_{3}\right) \delta 149.8,145.2,142.5,136.0,134.2,129.7,129.7$, 124.6, 120.0, 116.1, 112.9, 112.3, 105.9, 93.0, 56.4, 56.1. HRMS (ESI) calc'd for $\mathrm{C}_{16} \mathrm{H}_{16} \mathrm{NO}_{2} \mathrm{Br}_{2}\left([\mathrm{M}+\mathrm{H}]^{+}\right)$411.9542. Found: 411.9529.

\section{[2-(2,2-Dibromovinyl)phenyl]-(4-trifluoromethylphenyl)amine (24d)}
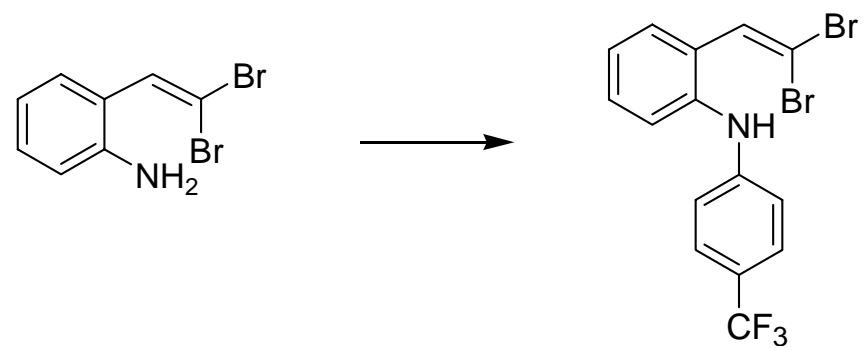

The general procedure for $\mathrm{Cu}(\mathrm{OAc})_{2}$-mediated coupling was followed using 1a (0.281 g, $1.01 \mathrm{mmol})$, 4-trifluoromethyl phenylboronic acid (0.360 g, $2 \mathrm{mmol}), \mathrm{Cu}(\mathrm{OAc})_{2}$ $(0.182 \mathrm{~g}, 1 \mathrm{mmol})$, myristic acid $(0.092 \mathrm{~g}, 0.4 \mathrm{mmol})$ and 2,6-lutidine $(125 \mu \mathrm{L}, 1.07$ mmol) in toluene $(3 \mathrm{~mL})$. The mixture was stirred at $40^{\circ} \mathrm{C}$ for $21 \mathrm{~h}$ and at $60^{\circ} \mathrm{C}$ for $3 \mathrm{~h}$ under an $\mathrm{O}_{2}$ atmosphere. The crude material was further purified by flash chromatography (2.5\% EtOAc in hexanes) to afford the desired product as a solid ( 0.352 $\mathrm{g}, 84 \%) . \mathrm{R}_{\mathrm{f}}=0.15\left(2.5 \%\right.$ EtOAc in hexanes). $\mathrm{mp} 74-75^{\circ} \mathrm{C}$. IR (neat, $\left.\mathrm{cm}^{-1}\right): 3405,1616$, $1597,1524,1323,1162,1113,1066 .{ }^{1} \mathrm{H}$ NMR $\left(400 \mathrm{MHz}, \mathrm{CDCl}_{3}\right) \delta 7.56(1 \mathrm{H}, \mathrm{d}, J=7.7$ $\mathrm{Hz}), 7.48(2 \mathrm{H}, \mathrm{d}, J=8.6 \mathrm{~Hz}), 7.38(1 \mathrm{H}, \mathrm{s}), 7.33-7.32(2 \mathrm{H}, \mathrm{m}), 7.17-7.13(1 \mathrm{H}, \mathrm{m}), 6.97$ $(2 \mathrm{H}, \mathrm{d}, J=8.4 \mathrm{~Hz}), 5.67(1 \mathrm{H}, \mathrm{s}) .{ }^{13} \mathrm{C} \mathrm{NMR}\left(75 \mathrm{MHz}, \mathrm{CDCl}_{3}\right) \delta 146.7,139.0,134.0$, $130.2,129.8,128.7,126.9\left(\mathrm{q}, J_{\mathrm{C}-\mathrm{F}}=3.7 \mathrm{~Hz}\right), 124.7\left(\mathrm{q}, J_{\mathrm{C}-\mathrm{F}}=269 \mathrm{~Hz}\right), 123.5,122.4\left(\mathrm{q}, J_{\mathrm{C}-}\right.$ $\mathrm{F}=32.5 \mathrm{~Hz}), 121.0,116.2,93.5 .{ }^{19} \mathrm{~F}$ NMR $\left(376 \mathrm{MHz}, \mathrm{CDCl}_{3}\right) \delta-61.5$. HRMS (EI) calc'd for $\mathrm{C}_{15} \mathrm{H}_{10} \mathrm{NF}_{3} \mathrm{Br}_{2}\left([\mathrm{M}]^{+}\right)$418.9132. Found: 418.9147.

\section{[2-(2,2-Dibromovinyl)-phenyl]-o-tolylamine (24e)}



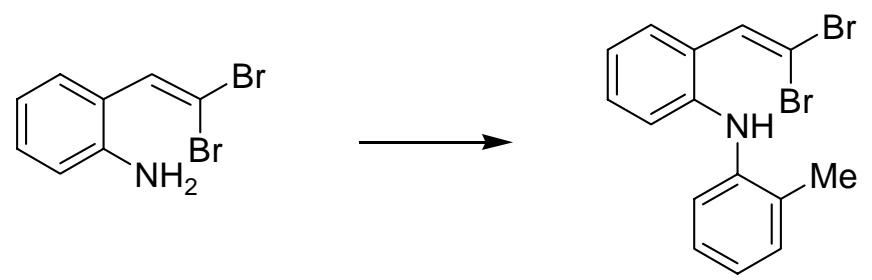

The general procedure for $\mathrm{Cu}(\mathrm{OAc})_{2}$-mediated coupling was followed using 1a $(0.280 \mathrm{~g}, 1.01 \mathrm{mmol})$, o-tolylboronic acid $(0.272 \mathrm{~g}, 2 \mathrm{mmol}), \mathrm{Cu}(\mathrm{OAc})_{2}(0.182 \mathrm{~g}, 1$ mmol), myristic acid (0.092 g, $0.4 \mathrm{mmol})$ and 2,6-lutidine $(125 \mu \mathrm{L}, 1.07 \mathrm{mmol})$ in toluene $(3 \mathrm{~mL})$. The mixture was stirred at $40{ }^{\circ} \mathrm{C}$ for $21 \mathrm{~h}$ and at $60{ }^{\circ} \mathrm{C}$ for $4 \mathrm{~h}$ under an $\mathrm{O}_{2}$ atmosphere. The crude material was further purified by flash chromatography $(2.5 \%$ EtOAc in hexanes) to afford the desired product as a solid $(0.255 \mathrm{~g}, 69 \%) . \mathrm{R}_{\mathrm{f}}=0.38$ (2.5\% EtOAc in hexanes). mp 65-67 ${ }^{\circ} \mathrm{C}$. IR (neat, $\mathrm{cm}^{-1}$ ): 3391, 2924, 1585, 1504, 1455, 1307. ${ }^{1} \mathrm{H}$ NMR (400 MHz, $\left.\mathrm{CDCl}_{3}\right) \delta 7.46(1 \mathrm{H}, \mathrm{dd}, J=7.3,0.9 \mathrm{~Hz}), 7.41(1 \mathrm{H}, \mathrm{s}), 7.24-$ $7.20(2 \mathrm{H}, \mathrm{m}), 7.14(1 \mathrm{H}, \mathrm{t}, J=7.6 \mathrm{~Hz}), 7.07(1 \mathrm{H}, \mathrm{d}, J=7.0 \mathrm{~Hz}), 7.00-6.92(3 \mathrm{H}, \mathrm{m}), 5.23$ $(1 \mathrm{H}, \mathrm{s}), 2.24(3 \mathrm{H}, \mathrm{s}) .{ }^{13} \mathrm{C} \mathrm{NMR}\left(75 \mathrm{MHz}, \mathrm{CDCl}_{3}\right) \delta 141.8,141.0,134.4,131.2,129.7$, 129.3, 127.1, 125.6, 122.9, 120.7, 120.2, 117.7, 93.2, 18.1. HRMS (EI) calc'd for $\mathrm{C}_{15} \mathrm{H}_{13} \mathrm{NBr}_{2}\left([\mathrm{M}]^{+}\right)$364.9415. Found: 364.9420 .

\section{[2-(2,2-Dichloro-1-methylvinyl)phenyl]-(4-fluorophenyl)amine (25b)}<smiles>CC(=C(Cl)Cl)c1ccccc1N</smiles><smiles>CC(=C(Cl)Cl)c1ccccc1Nc1ccc(F)cc1</smiles>

The general procedure for $\mathrm{Cu}(\mathrm{OAc})_{2}$-mediated coupling was followed using 13b (0.200 g, $1 \mathrm{mmol})$, 4-fluorophenylboronic acid $(0.280 \mathrm{~g}, 2 \mathrm{mmol}), \mathrm{Cu}(\mathrm{OAc})_{2}(0.182 \mathrm{~g}, 1$ mmol), myristic acid (0.092 g, $0.4 \mathrm{mmol})$ and 2,6-lutidine $(125 \mu \mathrm{L}, 1.07 \mathrm{mmol})$ in toluene $(3 \mathrm{~mL})$. The mixture was stirred at $40{ }^{\circ} \mathrm{C}$ for $35 \mathrm{~h}$ under an $\mathrm{O}_{2}$ atmosphere. The crude material was further purified by flash chromatography (2.5\% EtOAc in hexanes) to 
afford the desired product as an oil $(0.193 \mathrm{~g}, 65 \%)$ and starting aniline $(0.061 \mathrm{~g}, 30 \%)$. $\mathrm{R}_{\mathrm{f}}$ $=0.25$ (5\% EtOAc in hexanes). IR (neat, $\left.\mathrm{cm}^{-1}\right): 3415,2923,1598,1580,1509,1451$, 1309, 1217. ${ }^{1} \mathrm{H}$ NMR (400 MHz, $\left.\mathrm{CDCl}_{3}\right) \delta 7.19(1 \mathrm{H}$, ddd, $J=7.7,7.7,1.5 \mathrm{~Hz}), 7.11-6.96$ $(6 \mathrm{H}, \mathrm{m}), 6.92(1 \mathrm{H}, \mathrm{ddd}, J=7.4,7.4,1.2 \mathrm{~Hz}), 5.35(1 \mathrm{H}, \mathrm{s}), 2.15(3 \mathrm{H}, \mathrm{s}) .{ }^{13} \mathrm{C}$ NMR $(100$ $\left.\mathrm{MHz}, \mathrm{CDCl}_{3}\right) \delta 159.1\left(J_{\mathrm{C}-\mathrm{F}}=241 \mathrm{~Hz}\right), 140.8,138.9\left(J_{\mathrm{C}-\mathrm{F}}=2.6 \mathrm{~Hz}\right), 134.0,129.2,129.1$, 129.0, $122.9\left(J_{\mathrm{C}-\mathrm{F}}=7.8 \mathrm{~Hz}\right), 120.9,119.0,116.7,116.2\left(J_{\mathrm{C}-\mathrm{F}}=22.4 \mathrm{~Hz}\right), 22.2 .{ }^{19} \mathrm{~F}$ NMR $\left(376 \mathrm{MHz}, \mathrm{CDCl}_{3}\right) \delta$-121.2. HRMS (EI) calc'd for $\mathrm{C}_{15} \mathrm{H}_{12} \mathrm{NFCl}_{2}\left([\mathrm{M}]^{+}\right) 295.0331$. Found: 295.0330 .

\section{[2-(2,2-Dichloro-1-methylvinyl)-phenyl](3,4-dimethoxyphenyl)amine (25c)}
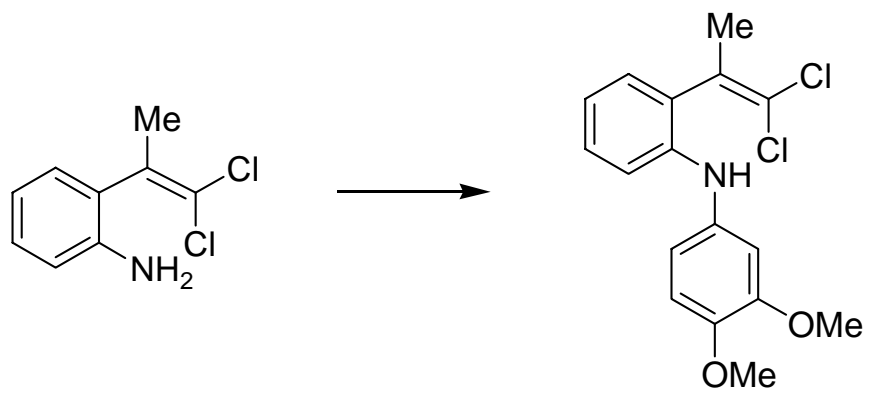

The general procedure for $\mathrm{Cu}(\mathrm{OAc})_{2}$-mediated coupling was followed using 13b (0.105 g, $0.52 \mathrm{mmol})$, 3,4-dimethoxyphenylboronic acid (0.182 g, $1 \mathrm{mmol}), \mathrm{Cu}(\mathrm{OAc})_{2}$ (0.091 g, $0.5 \mathrm{mmol})$, myristic acid $(0.046 \mathrm{~g}, 0.2 \mathrm{mmol})$ and 2,6-lutidine $(62.5 \mu \mathrm{L}, 0.54$ mmol) in toluene $(1.5 \mathrm{~mL})$. The mixture was stirred at $40{ }^{\circ} \mathrm{C}$ for $8 \mathrm{~h}$ under an $\mathrm{O}_{2}$ atmosphere. The crude material was further purified by flash chromatography $(10 \rightarrow 15 \%$ EtOAc in hexanes) to afford the desired product as a solid $(0.1566 \mathrm{~g}, 89 \%) . \mathrm{R}_{\mathrm{f}}=0.28$ (20\% EtOAc in hexanes). mp 94-96 ${ }^{\circ} \mathrm{C}$. IR (neat, $\mathrm{cm}^{-1}$ ): 3367, 2931, 1597, 1512, 1449, 1257, 1232, 1027. ${ }^{1} \mathrm{H}$ NMR $\left(400 \mathrm{MHz}, \mathrm{CDCl}_{3}\right) \delta 7.16(1 \mathrm{H}$, ddd, $J=7.8,7.8,1.4 \mathrm{~Hz})$, $7.07(1 \mathrm{H}, \mathrm{dd}, J=8.2,1.2 \mathrm{~Hz}), 7.05(1 \mathrm{H}, \mathrm{dd}, J=7.6,1.6 \mathrm{~Hz}), 6.86(1 \mathrm{H}, \mathrm{ddd}, J=7.4,7.4$, $1.2 \mathrm{~Hz}), 6.81(1 \mathrm{H}, \mathrm{d}, J=8.3 \mathrm{~Hz}), 6.69-6.66(2 \mathrm{H}, \mathrm{m}), 5.32(1 \mathrm{H}, \mathrm{s}), 3.86(3 \mathrm{H}, \mathrm{s}), 3.84(3 \mathrm{H}$, s), $2.17(3 \mathrm{H}, \mathrm{s}) .{ }^{13} \mathrm{C} \mathrm{NMR}\left(100 \mathrm{MHz}, \mathrm{CDCl}_{3}\right) \delta 149.8,145.3,141.5,136.1,134.1,129.0$, $128.8,128.2$, 120.0, 118.8, 115.7, 113.5, 112.3, 106.5, 56.4, 56.1, 22.1. HRMS (ESI) calc'd for $\mathrm{C}_{17} \mathrm{H}_{18} \mathrm{NO}_{2} \mathrm{Cl}_{2}\left([\mathrm{M}+\mathrm{H}]^{+}\right)$338.0709. Found: 338.0720 . 


\section{[2-(2,2-Dichloro-1-methylvinyl)-phenyl]-(4-trifluoromethylphenyl)amine (25d)}<smiles>CC(=C(Cl)Cl)c1ccccc1N</smiles><smiles>CC(=C(Cl)Cl)c1ccccc1Nc1ccc(C(F)(F)F)cc1</smiles>

The general procedure for $\mathrm{Cu}(\mathrm{OAc})_{2}$-mediated coupling was followed using $\mathbf{1 3 b}$ ( $0.204 \mathrm{~g}, 1.01 \mathrm{mmol})$, 4-trifluoromethyl phenylboronic acid (0.380 g, $2 \mathrm{mmol}), \mathrm{Cu}(\mathrm{OAc})_{2}$ $(0.363 \mathrm{~g}, 2 \mathrm{mmol})$, myristic acid $(0.114 \mathrm{~g}, 0.5 \mathrm{mmol})$ and 2,6-lutidine $(125 \mu \mathrm{L}, 1.07$ $\mathrm{mmol})$ in toluene $(3 \mathrm{~mL})$. The mixture was stirred at $\mathrm{rt}$ for $18 \mathrm{~h}$ and at $40{ }^{\circ} \mathrm{C}$ for $4 \mathrm{~h}$ under an $\mathrm{O}_{2}$ atmosphere. The crude material was further purified by flash chromatography (2.5\% EtOAc in hexanes) to afford the desired product as an oil $(0.240 \mathrm{~g}, 69 \%) \cdot \mathrm{R}_{\mathrm{f}}=0.32$ (5\% EtOAc in hexanes). IR (neat, $\left.\mathrm{cm}^{-1}\right): 3418,3061,1615,1598,1578,1525,1505$, 1453, 1318, 1162, 1112, 1067. ${ }^{1} \mathrm{H}$ NMR (400 MHz, $\left.\mathrm{CDCl}_{3}\right) \delta 7.47(2 \mathrm{H}, \mathrm{d}, J=8.4 \mathrm{~Hz})$, $7.37(1 \mathrm{H}, \mathrm{dd}, J=8.3,1.2 \mathrm{~Hz}), 7.29(1 \mathrm{H}, \mathrm{ddd}, J=7.7,7.7,1.5 \mathrm{~Hz}), 7.17(1 \mathrm{H}, \mathrm{dd}, J=7.8$, $1.4 \mathrm{~Hz}), 7.10(1 \mathrm{H}, \mathrm{ddd}, J=7.4,7.4,1.3 \mathrm{~Hz}), 7.01(2 \mathrm{H}, \mathrm{d}, J=8.4 \mathrm{~Hz}), 5.63(1 \mathrm{H}, \mathrm{s}), 2.10$ $(3 \mathrm{H}, \mathrm{s}) .{ }^{13} \mathrm{C} \mathrm{NMR}\left(100 \mathrm{MHz}, \mathrm{CDCl}_{3}\right) \delta 147.0,138.0,133.9,132.7,129.5,129.2,126.9$ $\left(\mathrm{q}, J_{\mathrm{C}-\mathrm{F}}=3.1 \mathrm{~Hz}\right), 124.8\left(\mathrm{q}, J_{\mathrm{C}-\mathrm{F}}=271 \mathrm{~Hz}\right), 123.7,122.3\left(\mathrm{q}, J_{\mathrm{C}-\mathrm{F}}=32.2 \mathrm{~Hz}\right), 121.1,119.0$, 116.1, 22.3. ${ }^{19} \mathrm{~F}$ NMR (376 MHz, $\left.\mathrm{CDCl}_{3}\right) \delta$-61.5. HRMS (EI) calc'd for $\mathrm{C}_{16} \mathrm{H}_{12} \mathrm{NF}_{3} \mathrm{Cl}_{2}$ $\left([\mathrm{M}]^{+}\right)$345.0299. Found: 345.0297.

1-\{4-[2-(2,2-Dichloro-1-methylvinyl)phenylamino]phenyl\}ethanone (25e)<smiles>CC(=C(Cl)Cl)c1ccccc1N</smiles><smiles>CC(=O)c1ccc(Nc2ccccc2C(C)=C(Cl)Cl)cc1</smiles> 
The general procedure for $\mathrm{Cu}(\mathrm{OAc})_{2}$-mediated coupling was followed using $\mathbf{1 3 b}$ (0.218 g, $1.08 \mathrm{mmol})$, 4-acetyl phenylboronic acid (0.338 g, $2 \mathrm{mmol}), \mathrm{Cu}(\mathrm{OAc})_{2}(0.273$ g, $1.5 \mathrm{mmol})$, myristic acid $(0.092 \mathrm{~g}, 0.4 \mathrm{mmol})$ and 2,6-lutidine $(125 \mu \mathrm{L}, 1.07 \mathrm{mmol})$ in toluene $(3 \mathrm{~mL})$. The mixture was stirred at $40{ }^{\circ} \mathrm{C}$ for $5 \mathrm{~h}$ and at $60^{\circ} \mathrm{C}$ for $5 \mathrm{~h}$ under an $\mathrm{O}_{2}$ atmosphere. The crude material was further purified by flash chromatography $(10 \% \rightarrow 15 \% \rightarrow 20 \%$ EtOAc in hexanes) to afford the desired product as a solid $(0.242 \mathrm{~g}$, $70 \%) . \mathrm{R}_{\mathrm{f}}=0.23$ (20\% EtOAc in hexanes). $\mathrm{mp} 81-82{ }^{\circ} \mathrm{C} . \mathrm{IR}$ (neat, $\mathrm{cm}^{-1}$ ): 3324, 1661, 1592, 1519, 1276, 1178. ${ }^{1} \mathrm{H}$ NMR (400 MHz, $\left.\mathrm{CDCl}_{3}\right) \delta 7.86(2 \mathrm{H}, \mathrm{d}, J=8.6 \mathrm{~Hz}), 7.40$ $(1 \mathrm{H}, \mathrm{d}, J=7.7 \mathrm{~Hz}), 7.31(1 \mathrm{H}, \mathrm{ddd}, J=7.7,7.7,1.6 \mathrm{~Hz}), 7.19(1 \mathrm{H}, \mathrm{dd}, J=7.6,1.6 \mathrm{~Hz})$, $7.13(1 \mathrm{H}, \mathrm{ddd}, J=7.5,7.5,1.1 \mathrm{~Hz}), 6.95(2 \mathrm{H}, \mathrm{d} J=8.8 \mathrm{~Hz}), 5.87(1 \mathrm{H}, \mathrm{s}), 2.53(3 \mathrm{H}, \mathrm{s})$, $2.09(3 \mathrm{H}, \mathrm{s}) .{ }^{13} \mathrm{C} \mathrm{NMR}\left(100 \mathrm{MHz}, \mathrm{CDCl}_{3}\right) \delta 196.6,148.7,137.4,133.9,133.3,130.8$, 129.6, 129.5, 129.2, 124.2, 122.2, 119.0, 115.0, 26.4, 22.3. HRMS (ESI) calc'd for $\mathrm{C}_{17} \mathrm{H}_{16} \mathrm{NOCl}_{2}\left([\mathrm{M}+\mathrm{H}]^{+}\right)$320.0603. Found: 320.0598 .

\section{[2-(2,2-Dichloro-1-methylvinyl)phenyl]-o-tolylamine (25f)}
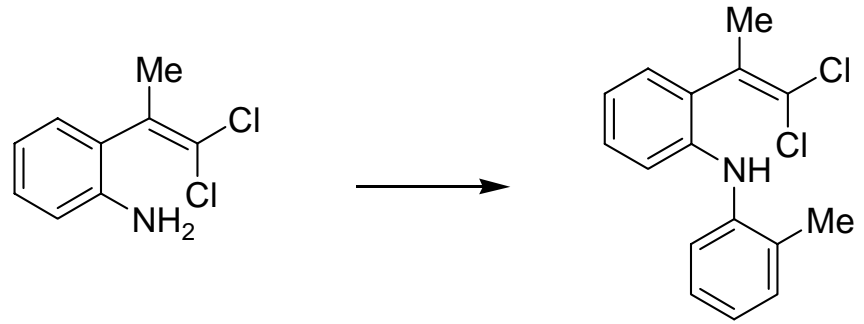

The general procedure for $\mathrm{Cu}(\mathrm{OAc})_{2}$-mediated coupling was followed using 13b (0.210 g, $1.04 \mathrm{mmol})$, o-tolylboronic acid (0.272 g, $2 \mathrm{mmol}), \mathrm{Cu}(\mathrm{OAc})_{2}(0.273 \mathrm{~g}, 1.5$ mmol), myristic acid (0.092 $\mathrm{g}, 0.4 \mathrm{mmol})$ and 2,6-lutidine $(125 \mu \mathrm{L}, 1.07 \mathrm{mmol})$ in toluene $(3 \mathrm{~mL})$. The mixture was stirred at $40^{\circ} \mathrm{C}$ for $13.5 \mathrm{~h}$ and at $60^{\circ} \mathrm{C}$ for $9 \mathrm{~h}$ under an $\mathrm{O}_{2}$ atmosphere. The crude material was further purified by flash chromatography $(2.5 \%$ EtOAc in hexanes) to afford the desired product as a solid $(0.213 \mathrm{~g}, 70 \%) . \mathrm{R}_{\mathrm{f}}=0.35$ (2.5\% EtOAc in hexanes). mp 49-51 ${ }^{\circ} \mathrm{C}$. IR (neat, $\mathrm{cm}^{-1}$ ): 3428, 3034, 2918, 1584, 1504, 1452, 1306, 1026. ${ }^{1} \mathrm{H}$ NMR (400 MHz, $\left.\mathrm{CDCl}_{3}\right) \delta 7.21(1 \mathrm{H}, \mathrm{d}, J=7.5 \mathrm{~Hz}), 7.18-7.14(3 \mathrm{H}$, m), $7.08(1 \mathrm{H}, \mathrm{dd}, J=7.6,1.4 \mathrm{~Hz}), 7.00-6.96(2 \mathrm{H}, \mathrm{m}), 6.90(1 \mathrm{H}, \mathrm{t}, J=7.5 \mathrm{~Hz}), 5.28(1 \mathrm{H}$, s), $2.24(3 \mathrm{H}, \mathrm{s}), 2.16(3 \mathrm{H}, \mathrm{s}) .{ }^{13} \mathrm{C} \mathrm{NMR}\left(75 \mathrm{MHz}, \mathrm{CDCl}_{3}\right) \delta 140.9,140.6,134.2,131.2$, 
129.7, 129.0, 128.8, 127.0, 123.0, 120.5, 120.4, 118.8, 116.7, 22.2, 18.0. HRMS (EI) calc'd for $\mathrm{C}_{16} \mathrm{H}_{15} \mathrm{NCl}_{2}\left([\mathrm{M}]^{+}\right)$291.0581. Found: 291.0588 .

\section{1-(2-Fluoro-5-nitrophenyl)ethanone (21)}

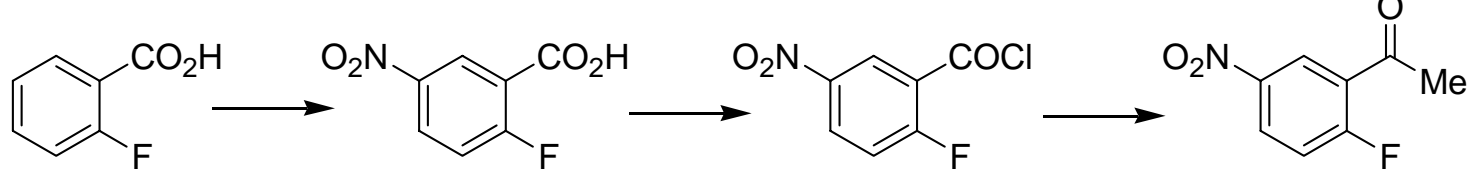

Concentrated $\mathrm{HNO}_{3}(67-70 \%, 63 \mathrm{~mL})$ was added portion-wise to concentrated $\mathrm{H}_{2} \mathrm{SO}_{4}$ $(98 \%, 63 \mathrm{~mL})$, and the mixture was cooled to $10{ }^{\circ} \mathrm{C}$. To the the vigously stirring mixed acids was dded 2-fluorobenzoic acid (28 g, $0.2 \mathrm{~mol})$. The rate of addition was controlled so that the internal temperature was maintained at $15-25^{\circ} \mathrm{C}$ using an ice bath to cool the reaction mixture occationally. After completion of addition, the mixture was stirred at rt for $45 \mathrm{~min}$ followed by at $30{ }^{\circ} \mathrm{C}$ for $1 \mathrm{~h}$, and poured into crashed ice $(1 \mathrm{~L})$. After filtration, the collected white solid was washed with a copious amount of water, and dried under high vacuum $(32.9 \mathrm{~g}, 89 \%) .{ }^{1} \mathrm{H}$ NMR $\left(500 \mathrm{MHz}, \mathrm{CDCl}_{3}\right) \delta 10.80(1 \mathrm{H}, \mathrm{br}), 8.77$ $(1 \mathrm{H}, \mathrm{dd}, J=6.1,2.9 \mathrm{~Hz}), 8.51\left(1 \mathrm{H}, \mathrm{dt}, J^{\mathrm{d}}=9.1 \mathrm{~Hz}, J^{\mathrm{d}}=3.4 \mathrm{~Hz}\right), 7.40(1 \mathrm{H}, \mathrm{t}, J=9.2 \mathrm{~Hz})$. To a mixture of the acid $(9.26 \mathrm{~g}, 50 \mathrm{mmol})$ and $\mathrm{SOCl}_{2}(6.4 \mathrm{~mL}, 90 \mathrm{mmol})$ in a roundbottomed flask attached with a condenser and a drying tube was added DMF (10 drops). The mixture was heated at $75^{\circ} \mathrm{C}$ unitl the mixture became homogenous. The solvent was removed under vacuum and the residue was tranfered into a sublimation apparatus and covered with sea sand. Sublimation at $80^{\circ} \mathrm{C}(0.5 \mathrm{~mm}$ torr $)$ afforded the acid chloride as a white crystalline solid (10.0 g, 98\%).

To a solution of $\mathrm{ZnBr}_{2}(1.69 \mathrm{~g}, 7.5 \mathrm{mml})$ in THF $(18 \mathrm{~mL})$ was added a solution of $\mathrm{CH}_{3} \mathrm{MgBr}\left(3 \mathrm{M}\right.$ in $\left.\mathrm{Et}_{2} \mathrm{O}, 2 \mathrm{~mL}, 6 \mathrm{mmol}\right)$ at $-78{ }^{\circ} \mathrm{C}$. After addition, the mixture was warmed to rt and stirred for $15 \mathrm{~min}$. The mixture was cooled to $-78^{\circ} \mathrm{C}$ and added 2fluoro-5-nitrobenzoyl chloride $(1.14 \mathrm{~g}, 5.0 \mathrm{mmol})$ followed by $\mathrm{Pd}\left(\mathrm{PPh}_{3}\right)_{4}(0.115 \mathrm{~g}, 0.01$ mmol). The reaction mixture was warmed to $\mathrm{rt}$ and stirred for $14 \mathrm{~h}$ before quenched addition of $\mathrm{HCl}(1 \mathrm{M}, 10 \mathrm{~mL})$. The resulting mixture was extracted with $\mathrm{Et}_{2} \mathrm{O}(20 \mathrm{~mL})$, washed with $\mathrm{H}_{2} \mathrm{O}(15 \mathrm{~mL}), \mathrm{NaHCO}_{3}(15 \mathrm{~mL})$, brine $(15 \mathrm{~mL})$, and dried over $\mathrm{MgSO}_{4}$. Further purification by flash chromatography using $10 \rightarrow 15 \%$ EtOAc in hexanes afforded 21 as a white solid $(0.745 \mathrm{~g}, 81 \%)$. mp 53-54 ${ }^{\circ} \mathrm{C}$. IR (neat, $\left.\mathrm{cm}^{-1}\right)$ : 3094, 1695, 1622, 1534, 
1478, 1417, 1353, 1258, 1118. ${ }^{1} \mathrm{H}$ NMR (400 MHz, $\left.\mathrm{CDCl}_{3}\right) \delta 8.77(1 \mathrm{H}, \mathrm{dd}, J=6.2,3.1$ $\mathrm{Hz}), 8.42(1 \mathrm{H}, \mathrm{ddd}, J=8.7,4.2,3.1 \mathrm{~Hz}), 7.36(1 \mathrm{H}, \mathrm{t}, J=9.3 \mathrm{~Hz}), 2.71(3 \mathrm{H}, \mathrm{d}, J=4.8$ $\mathrm{Hz}) .{ }^{13} \mathrm{C} \mathrm{NMR}\left(100 \mathrm{MHz}, \mathrm{CDCl}_{3}\right) \delta 193.4(\mathrm{~J}=3.8 \mathrm{~Hz}), 165.2(\mathrm{~J}=265 \mathrm{~Hz}), 144.7,129.6$ $(J=10.7 \mathrm{~Hz}), 127.0(\mathrm{~J}=4.6 \mathrm{~Hz}), 126.6(\mathrm{~J}=16 \mathrm{~Hz}), 118.5(\mathrm{~J}=27 \mathrm{~Hz}), 31.4(\mathrm{~J}=6.9 \mathrm{~Hz})$.

${ }^{19} \mathrm{~F}$ NMR (376 MHz, $\left.\mathrm{CDCl}_{3}\right) \delta$-99.8. HRMS (EI) calc'd for $\mathrm{C}_{8} \mathrm{H}_{6} \mathrm{NO}_{3} \mathrm{~F}\left([\mathrm{M}]^{+}\right) 183.0332$. Found: 183.0332 .

2-(2,2-Dichloro-1-methylvinyl)-1-fluoro-4-nitrobenzene (22)<smiles>CC(=O)c1cc([N+](=O)[O-])ccc1F</smiles>

The procedure for the preparation of 12b was followed using ketone $2 \mathbf{1}$ (2.75 g, 15 $\mathrm{mmol}), \mathrm{CHCl}_{3}(3.58 \mathrm{~g}, 20 \mathrm{mmol}), \mathrm{PPh}_{3}(7.86 \mathrm{~g}, 30 \mathrm{mmol})$, and $t-\mathrm{BuOH} \cdot t-\mathrm{BuOK}(5.60 \mathrm{~g}$, $30 \mathrm{mmol}$ ). Product 22 was obtained as a slightly yellow oil $(3.62 \mathrm{~g}, 96 \%)$. IR (neat, $\left.\mathrm{cm}^{-1}\right)$ : 3089, 1617, 1581, 1532, 1351, 1254. ${ }^{1} \mathrm{H}$ NMR (400 MHz, $\left.\mathrm{CDCl}_{3}\right) \delta 8.24(1 \mathrm{H}, \mathrm{ddd}, J=$ 9.2, 4.2, $2.9 \mathrm{~Hz}), 8.18(1 \mathrm{H}, \mathrm{dd}, J=6.1,2.9 \mathrm{~Hz}), 7.26(1 \mathrm{H}, \mathrm{t}, J=8.8 \mathrm{~Hz}), 2.21(3 \mathrm{H}, \mathrm{s}) .{ }^{13} \mathrm{C}$ NMR $\left(100 \mathrm{MHz}, \mathrm{CDCl}_{3}\right) \delta 162.7(\mathrm{~J}=260 \mathrm{~Hz}), 144.4,129.1(\mathrm{~J}=18 \mathrm{~Hz}), 128.6,126.5(\mathrm{~J}$ $=5.4 \mathrm{~Hz}), 125.8(J=10 \mathrm{~Hz}), 121.5,117.3(\mathrm{~J}=25 \mathrm{~Hz}), 21.9 .{ }^{19} \mathrm{~F}$ NMR $(376 \mathrm{MHz}$, $\left.\mathrm{CDCl}_{3}\right) \delta$-103.3. HRMS (EI) calc'd for $\mathrm{C}_{9} \mathrm{H}_{6} \mathrm{Cl}_{2} \mathrm{FNO}_{2}\left([\mathrm{M}]^{+}\right)$248.9760. Found: 248.9763.

\section{[2-(2,2-Dichloro-1-methylvinyl)-4-nitrophenyl]methylamine (23)}<smiles>CNc1ccc([N+](=O)[O-])cc1C(C)=C(Cl)Cl</smiles>

A solution of $22(0.092 \mathrm{~g}, 0.37 \mathrm{mmol})$ and $\mathrm{MeNH}_{2}(40 \% \mathrm{aq}, 0.6 \mathrm{~mL})$ in $\mathrm{CH}_{3} \mathrm{CN}(0.6$ $\mathrm{mL}$ ) in a microwave vial was subjected to controlled microwave irradiation at $150{ }^{\circ} \mathrm{C}$ for $10 \mathrm{~min}$ (if reaction is not complete, longer reaction time may be required). Solvent was removed under vacuum, and the residue was extracted with $\mathrm{Et}_{2} \mathrm{O}$, and dried over $\mathrm{Na}_{2} \mathrm{SO}_{4}$. 
The product was obtained as a yellow solid by flash chromatography $(0.0926 \mathrm{~g}, 96 \%)$. mp 104-105 ${ }^{\circ} \mathrm{C}$. IR (neat, $\mathrm{cm}^{-1}$ ): 3387, 2918, 1584, 1495, 1325, 1300, 1112. ${ }^{1} \mathrm{H}$ NMR $\left(400 \mathrm{MHz}, \mathrm{CDCl}_{3}\right) \delta 8.15(1 \mathrm{H}, \mathrm{dd}, J=9.2,2.6 \mathrm{~Hz}), 7.89(1 \mathrm{H}, \mathrm{d}, J=2.6 \mathrm{~Hz}), 6.60(1 \mathrm{H}, \mathrm{t}$, $J=9.0 \mathrm{~Hz}), 4.48(1 \mathrm{H}, \mathrm{br}), 2.99(3 \mathrm{H}, \mathrm{d}, J=5.1 \mathrm{~Hz}), 2.14(3 \mathrm{H}, \mathrm{s}) .{ }^{13} \mathrm{C}$ NMR $(100 \mathrm{MHz}$, $\left.\mathrm{CDCl}_{3}\right) \delta 150.1,137.8,131.4,126.5,124.9,124.6,121.1,108.7,30.5,21.7$. HRMS (ESI) calc'd for $\mathrm{C}_{10} \mathrm{H}_{11} \mathrm{~N}_{2} \mathrm{O}_{2} \mathrm{Cl}_{2}\left([\mathrm{M}+\mathrm{H}]^{+}\right)$261.0192. Found: 261.0196 .

\section{1-Benzyl-2-phenyl-1H-indole (26a)}<smiles>BrC(Br)=Cc1ccccc1NCc1ccccc1</smiles><smiles>c1ccc(Cn2c(-c3ccccc3)cc3ccccc32)cc1</smiles>

General procedure A for the Pd-catalyzed tandem coupling was followed. A mixture of benzyl-[2-(2,2-dibromovinyl)-phenyl]-amine (0.184 g, $0.50 \mathrm{mmol}), \mathrm{PhB}(\mathrm{OH})_{2}(0.092$ $\mathrm{g}, 0.75 \mathrm{mmol}), \mathrm{K}_{3} \mathrm{PO}_{4} \cdot \mathrm{H}_{2} \mathrm{O}(0.58 \mathrm{~g}, 2.5 \mathrm{mmol})$, and a catalyst solution $\left(\mathrm{Pd}(\mathrm{OAc})_{2}(1.2\right.$ $\mathrm{mg}, 1 \mathrm{~mol} \%$ ) and S-Phos (4.1 mg, $2 \mathrm{~mol} \%)$ in PhMe $(2.5 \mathrm{~mL})$ ) was heated at $90{ }^{\circ} \mathrm{C}$ for 4 h. After an aqueous workup, the crude material was purified by flash chromatography (2.5\% EtOAc in hexanes) to afford 26a as a white crystalline solid $(0.116 \mathrm{~g}, 82 \%) .{ }^{18} \mathrm{H}$ NMR (300 MHz, $\left.\mathrm{CDCl}_{3}\right) \delta$ 7.69-7.64 $(1 \mathrm{H}, \mathrm{m}), 7.44-7.40(2 \mathrm{H}, \mathrm{m}), 7.38-7.33(3 \mathrm{H}, \mathrm{m})$, 7.28-7.22 (3H, m), 7.18-7.12 (2H, m), $7.10(1 \mathrm{H}, \mathrm{d}, J=7.0 \mathrm{~Hz}), 6.65(1 \mathrm{H}, \mathrm{s}), 5.35(2 \mathrm{H}, \mathrm{s})$.

${ }^{13} \mathrm{C}$ NMR $\left(75 \mathrm{MHz}, \mathrm{CDCl}_{3}\right) \delta 142.0,138.4,138.2,132.9,129.4,128.9,128.8,128.5$, $128.2,127.4,126.1,122.1,120.8,120.4,110.8,102.5,47.9$.

\section{1-Isopropyl-2-phenyl-1H-indole (26b)}
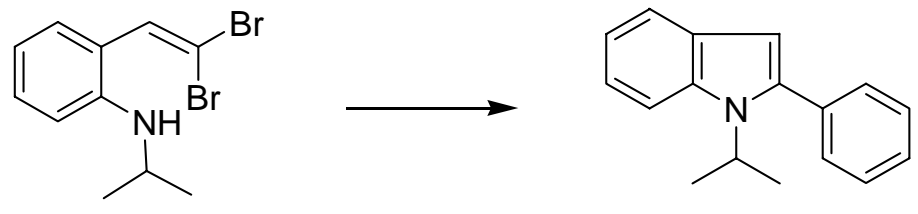

\footnotetext{
${ }^{18}$ Lane, B. S.; Sames, D. Org. Lett. 2004, 6, 2897.
} 
General procedure A for the Pd-catalyzed tandem coupling was followed using [2(2,2-dibromovinyl)-phenyl]-isopropylamine (0.200 g, $0.63 \mathrm{mmol}), \mathrm{PhB}(\mathrm{OH})_{2}(0.115 \mathrm{~g}$, $0.95 \mathrm{mmol}), \mathrm{Pd}(\mathrm{OAc})_{2}(2.8 \mathrm{mg}, 0.013 \mathrm{mmol}), \mathrm{K}_{3} \mathrm{PO}_{4} \cdot \mathrm{H}_{2} \mathrm{O}(0.725 \mathrm{~g}, 3.2 \mathrm{mmol})$, and SPhos $(10.3 \mathrm{mg}, 0.026 \mathrm{mmol})$. After heating at $100{ }^{\circ} \mathrm{C}$ for $2 \mathrm{~h}$, the product was obtained as a white solid after flash chromatography using 2.5\% EtOAc in hexanes $(0.1055 \mathrm{~g}$, $71 \%) .{ }^{18}{ }^{1} \mathrm{H} \mathrm{NMR}\left(300 \mathrm{MHz}, \mathrm{CDCl}_{3}\right) \delta 7.62\left(2 \mathrm{H}, \mathrm{tm}, J^{\mathrm{t}}=7.1 \mathrm{~Hz}\right), 7.47-7.38(5 \mathrm{H}, \mathrm{m})$, $7.18(1 \mathrm{H}, \mathrm{ddd}, J=8.0,7.2,1.5 \mathrm{~Hz}), 7.11(1 \mathrm{H}, \mathrm{ddd}, J=7.9,7.0,1.1 \mathrm{~Hz}), 6.45(1 \mathrm{H}, \mathrm{d}, J=$ $0.9 \mathrm{~Hz}), 4.68(1 \mathrm{H}$, septet, $J=7.0 \mathrm{~Hz}), 1.61(6 \mathrm{H}, \mathrm{d}, J=7.0 \mathrm{~Hz})$.

\section{1,2-Diphenyl-1H-indole (26c)}

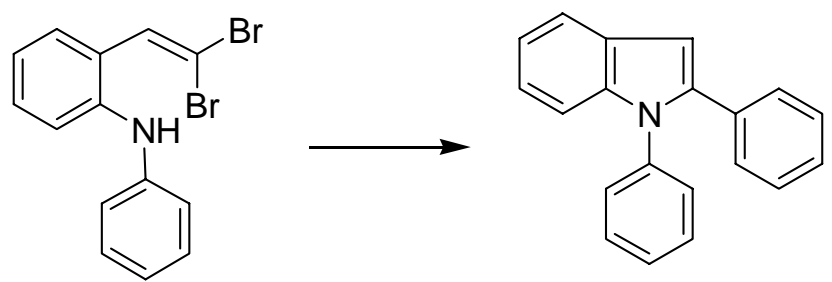

General procedure A for the Pd-catalyzed tandem coupling was followed using [2(2,2-dibromovinyl)-phenyl]-phenylamine (0.108 g, $0.306 \mathrm{mmol}), \mathrm{PhB}(\mathrm{OH})_{2}(0.055 \mathrm{~g}$, $0.45 \mathrm{mmol}), \mathrm{K}_{3} \mathrm{PO}_{4} \cdot \mathrm{H}_{2} \mathrm{O}(0.35 \mathrm{~g}, 1.5 \mathrm{mmol})$, and a catalyst solution $\left(\mathrm{Pd}(\mathrm{OAc})_{2}(2.2 \mathrm{mg}, 3\right.$ mol\%) and S-Phos (8.1 mg, $6 \mathrm{~mol} \%)$ in PhMe (1.5 mL)). After heating at $100{ }^{\circ} \mathrm{C}$ for $1 \mathrm{~h}$, the crude material was purified by flash chromatography $(2.5 \%$ EtOAc in hexanes) to afford a white solid (0.076 g, 92\%). mp 78-80 ${ }^{\circ} \mathrm{C}$ (Lit. $\left.81{ }^{\circ} \mathrm{C}\right){ }^{19} .{ }^{1} \mathrm{H}$ NMR $(300 \mathrm{MHz}$, $\left.\mathrm{CDCl}_{3}\right) \delta 7.71-7.77(1 \mathrm{H}, \mathrm{m}), 7.40\left(2 \mathrm{H}, \mathrm{tm}, J^{\mathrm{t}}=7.7 \mathrm{~Hz}\right), 7.33\left(1 \mathrm{H}, \mathrm{tm}, J^{\mathrm{t}}=7.6 \mathrm{~Hz}\right), 7.30-$ $7.20(8 \mathrm{H}, \mathrm{m}), 7.29-7.25(2 \mathrm{H}, \mathrm{m}), 6.80(1 \mathrm{H}, \mathrm{s})$.

\section{1-(4-Fluorophenyl)-2-phenyl-1H-indole (26f)}

\footnotetext{
${ }^{19}$ Horrocks, D. L.; Wirth, H. O. J. Chem. Phys. 1967, 47, 3241.
} 


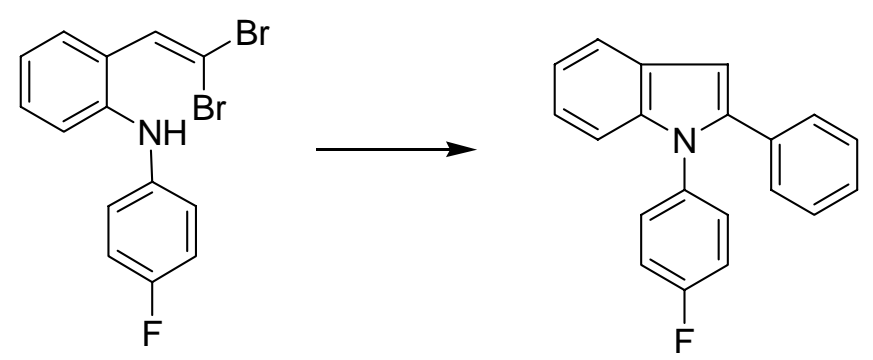

General procedure A for the Pd-catalyzed tandem coupling was followed. A mixture of [2-(2,2-dibromovinyl)-phenyl]-phenyl-amine $(0.111 \mathrm{~g}, 0.30 \mathrm{mmol}), \mathrm{PhB}(\mathrm{OH})_{2}(0.055$ $\mathrm{g}, 0.45 \mathrm{mmol}), \mathrm{K}_{3} \mathrm{PO}_{4} \cdot \mathrm{H}_{2} \mathrm{O}(0.35 \mathrm{~g}, 1.5 \mathrm{mmol})$, and a catalyst solution $\left(\mathrm{Pd}(\mathrm{OAc})_{2}(2.2\right.$ $\mathrm{mg}, 3 \mathrm{~mol} \%$ ) and S-Phos $(8.1 \mathrm{mg}, 6 \mathrm{~mol} \%)$ in PhMe $(1.5 \mathrm{~mL}))$ was heated at $100^{\circ} \mathrm{C}$ for 1 h. After an aqueous workup, the crude material was purified by flash chromatography $\left(2.5 \%\right.$ EtOAc in hexanes) to afford a white solid $(0.0775 \mathrm{~g}, 90 \%) . \mathrm{R}_{\mathrm{f}}=0.20(2.5 \%$ EtOAc in hexanes). mp 123-124 ${ }^{\circ} \mathrm{C} . \mathrm{IR}$ (neat, $\mathrm{cm}^{-1}$ ): 3062, 1601, 1509, 1457, 1324, 1222. ${ }^{1} \mathrm{H}$ NMR $\left(400 \mathrm{MHz}, \mathrm{CDCl}_{3}\right) \delta$ 7.69-7.65 (1H, m), 7.25-7.16 (10H, m), 7.09 (2H, t, $J=$ $8.5 \mathrm{~Hz}), 6.79(1 \mathrm{H}, \mathrm{s}) .{ }^{13} \mathrm{C} \mathrm{NMR}\left(100 \mathrm{MHz}, \mathrm{CDCl}_{3}\right) \delta 161.7\left(J_{\mathrm{C}-\mathrm{F}}=248 \mathrm{~Hz}\right), 141.0,139.3$, $134.8\left(J_{\mathrm{C}-\mathrm{F}}=3.1 \mathrm{~Hz}\right), 132.5,129.9\left(J_{\mathrm{C}-\mathrm{F}}=8.4 \mathrm{~Hz}\right), 129.1,128.5,128.4,127.7,122.7$, 121.0, 120.8, $116.4\left(J_{\mathrm{C}-\mathrm{F}}=23.0 \mathrm{~Hz}\right), 110.6,104.0 .{ }^{19} \mathrm{~F}$ NMR $\left(376 \mathrm{MHz}, \mathrm{CDCl}_{3}\right) \delta-114.2$. HRMS (EI) calc'd for $\mathrm{C}_{20} \mathrm{H}_{14} \mathrm{NF}\left([\mathrm{M}]^{+}\right)$287.1110. Found: 287.1115.

\section{1-(3,4-Dimethoxyphenyl)-2-(4-trifluoromethylphenyl)-1H-indole (26g)}

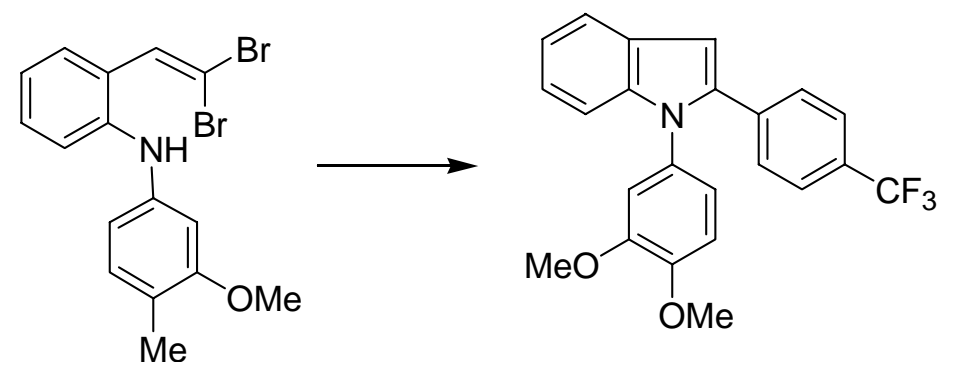

General procedure A for the Pd-catalyzed tandem coupling was followed. A mixture of [2-(2,2-dibromovinyl)-phenyl]-(3,4-dimethoxyphenyl)-amine (0.124 g, $0.30 \mathrm{mmol}), 4$ $\mathrm{CF}_{3} \mathrm{PhB}(\mathrm{OH})_{2}(0.083 \mathrm{~g}, 0.45 \mathrm{mmol}), \mathrm{K}_{3} \mathrm{PO}_{4} \cdot \mathrm{H}_{2} \mathrm{O}(0.35 \mathrm{~g}, 1.5 \mathrm{mmol})$, and a catalyst solution $\left(\mathrm{Pd}(\mathrm{OAc})_{2}(2.2 \mathrm{mg}, 3 \mathrm{~mol} \%)\right.$ and $\mathrm{S}-\mathrm{Phos}(8.1 \mathrm{mg}, 6 \mathrm{~mol} \%)$ in $\left.\mathrm{PhMe}(1.5 \mathrm{~mL})\right)$ was heated at $100{ }^{\circ} \mathrm{C}$ for $2.5 \mathrm{~h}$. After an aqueous workup, the crude material was purified by flash chromatography $(15 \% \rightarrow 20 \%$ EtOAc in hexanes $)$ to afford a white solid $(0.097$ 
$\mathrm{g}, 81 \%) . \mathrm{R}_{\mathrm{f}}=0.22\left(20 \%\right.$ EtOAc in hexanes). $\mathrm{mp} 190-191{ }^{\circ} \mathrm{C} . \mathrm{IR}$ (neat, $\left.\mathrm{cm}^{-1}\right): 2921,1612$, 1514, 1451, 1322, 1110. ${ }^{1} \mathrm{H}$ NMR (400 MHz, $\left.\mathrm{CDCl}_{3}\right) \delta$ 7.71-7.68 (1H, m), $7.50(2 \mathrm{H}, \mathrm{d}, J$ $=8.3 \mathrm{~Hz}), 7.40(2 \mathrm{H}, \mathrm{d}, J=8.1 \mathrm{~Hz}), 7.28(1 \mathrm{H}, \mathrm{d}, J=7.5 \mathrm{~Hz}), 7.23-7.17(2 \mathrm{H}, \mathrm{m}), 6.91(1 \mathrm{H}$, d, $J=8.6 \mathrm{~Hz}), 6.87(1 \mathrm{H}, \mathrm{s}), 6.83(1 \mathrm{H}, \mathrm{dd}, J=8.5,2.3 \mathrm{~Hz}), 6.74(1 \mathrm{H}, \mathrm{d}, J=2.2 \mathrm{~Hz}), 3.94$ $(3 \mathrm{H}, \mathrm{s}), 3.73(3 \mathrm{H}, \mathrm{s}) .{ }^{13} \mathrm{C} \mathrm{NMR}\left(100 \mathrm{MHz}, \mathrm{CDCl}_{3}\right) \delta 149.7,148.6,139.8,139.2,136.3$, $131.2,129.2\left(\mathrm{q}, J_{\mathrm{C}-\mathrm{F}}=32.7 \mathrm{~Hz}\right), 128.9,125.4\left(\mathrm{q}, J_{\mathrm{C}-\mathrm{F}}=3.6 \mathrm{~Hz}\right), 124.3\left(\mathrm{q}, J_{\mathrm{C}-\mathrm{F}}=272 \mathrm{~Hz}\right)$, 123.2, 121.1, 121.0, 120.5, 111.7, 111.5, 111.0, 104.6, 56.2. HRMS (EI) calc'd for $\mathrm{C}_{23} \mathrm{H}_{18} \mathrm{NO}_{2} \mathrm{~F}_{3}\left([\mathrm{M}]^{+}\right)$397.1290. Found: 397.1269.

\section{2-(2-Fluorophenyl)-1-(4-trifluoromethylphenyl)-1H-indole (26h)}
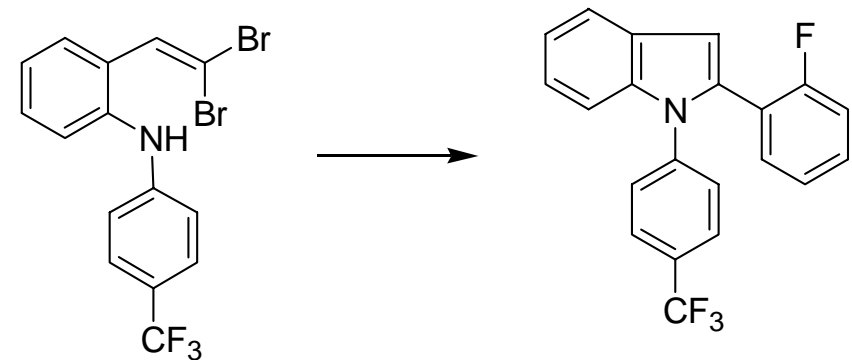

General procedure A for the Pd-catalyzed tandem coupling was followed. A mixture of [2-(2,2-dibromovinyl)-phenyl]-(4-trifluoromethylphenyl)-amine (0.126 g, $0.30 \mathrm{mmol})$, 2-FPhB $(\mathrm{OH})_{2}(0.063 \mathrm{~g}, 0.45 \mathrm{mmol}), \mathrm{K}_{3} \mathrm{PO}_{4} \cdot \mathrm{H}_{2} \mathrm{O}(0.35 \mathrm{~g}, 1.5 \mathrm{mmol})$, and a catalyst solution $\left(\mathrm{Pd}(\mathrm{OAc})_{2}(2.2 \mathrm{mg}, 3 \mathrm{~mol} \%)\right.$ and S-Phos $(8.1 \mathrm{mg}, 6 \mathrm{~mol} \%)$ in PhMe $\left.(1.5 \mathrm{~mL})\right)$ was heated at $100{ }^{\circ} \mathrm{C}$ for $2.5 \mathrm{~h}$. After an aqueous workup, the crude material was purified by flash chromatography ( $2.5 \%$ EtOAc in hexanes) to afford a white solid $(0.0873 \mathrm{~g}$, $82 \%) . \mathrm{R}_{\mathrm{f}}=0.22\left(2.5 \%\right.$ EtOAc in hexanes). $\mathrm{mp} 92-93{ }^{\circ} \mathrm{C}$. IR (neat, $\left.\mathrm{cm}^{-1}\right): 3061,1615$, 1452, 1324, 1168, 1127. ${ }^{1} \mathrm{H}$ NMR (400 MHz, $\left.\mathrm{CDCl}_{3}\right) \delta 7.72-7.70(1 \mathrm{H}, \mathrm{m}), 7.63(2 \mathrm{H}, \mathrm{d}, J$ $=8.3 \mathrm{~Hz}), 7.36-7.33(3 \mathrm{H}, \mathrm{m}), 7.31-7.27(2 \mathrm{H}, \mathrm{m}), 7.26-7.21(2 \mathrm{H}, \mathrm{m}), 7.10(1 \mathrm{H}, \mathrm{ddd}, J=$ 7.8, 7.3, $1.1 \mathrm{~Hz}), 6.98(1 \mathrm{H}$, ddd, $J=10.0,8.6,1.3 \mathrm{~Hz}), 6.85(1 \mathrm{H}, \mathrm{s}) .{ }^{13} \mathrm{C} \mathrm{NMR}(100 \mathrm{MHz}$, $\left.\mathrm{CDCl}_{3}\right) \delta 159.9\left(\mathrm{~d}, J_{\mathrm{C}-\mathrm{F}}=250 \mathrm{~Hz}\right), 141.8,138.3,134.6,132.0\left(\mathrm{~d}, J_{\mathrm{C}-\mathrm{F}}=3.1 \mathrm{~Hz}\right), 130.4(\mathrm{~d}$, $\left.J_{\mathrm{C}-\mathrm{F}}=7.5 \mathrm{~Hz}\right), 129.1\left(\mathrm{q}, J_{\mathrm{C}-\mathrm{F}}=33 \mathrm{~Hz}\right), 128.6,127.6,126.5\left(\mathrm{q}, J_{\mathrm{C}-\mathrm{F}}=3.8 \mathrm{~Hz}\right), 124.4\left(\mathrm{~d}, J_{\mathrm{C}-}\right.$ $\mathrm{F}=3.8 \mathrm{~Hz}), 124.1\left(\mathrm{q}, J_{\mathrm{C}-\mathrm{F}}=272 \mathrm{~Hz}\right), 123.3,121.4,121.2,120.6\left(\mathrm{~d}, J_{\mathrm{C}-\mathrm{F}}=14.6 \mathrm{~Hz}\right), 116.2$ $\left(\mathrm{d}, J_{\mathrm{C}-\mathrm{F}}=22.2 \mathrm{~Hz}\right), 110.5,106.7\left(\mathrm{~d}, J_{\mathrm{C}-\mathrm{F}}=2.3 \mathrm{~Hz}\right) .{ }^{19} \mathrm{~F} \mathrm{NMR}\left(376 \mathrm{MHz}, \mathrm{CDCl}_{3}\right) \delta-62.4$ 
(3F, s), -112.6 (1F, ddd). HRMS (EI) calc'd for $\mathrm{C}_{21} \mathrm{H}_{13} \mathrm{NF}_{4}\left([\mathrm{M}]^{+}\right)$355.0984. Found: 355.0999 .

2-(4-Methoxyphenyl)-3-methyl-1-(4-trifluoromethylphenyl)-1H-indole (27c)

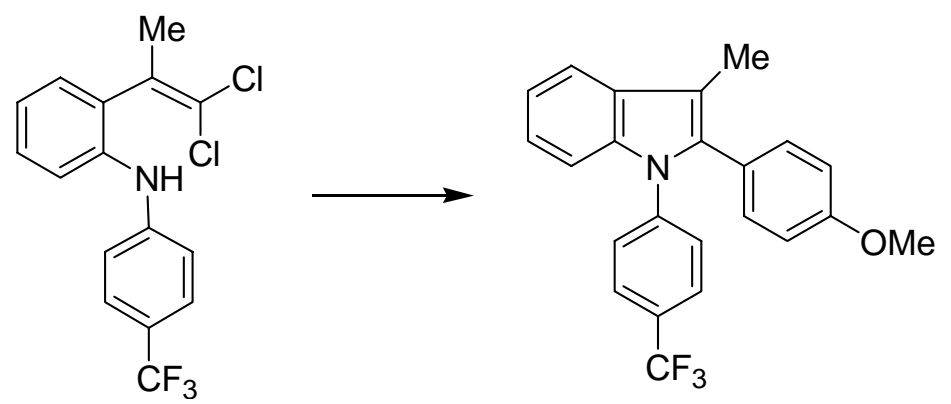

General procedure A for the Pd-catalyzed tandem coupling was followed. A mixture of [2-(2,2-dichloro-1-methylvinyl)-phenyl]-(4-trifluoromethylphenyl)-amine (0.106 g, $0.306 \mathrm{mmol}), 4-\mathrm{MeOPhB}(\mathrm{OH})_{2}(0.068 \mathrm{~g}, 0.45 \mathrm{mmol}), \mathrm{K}_{3} \mathrm{PO}_{4} \cdot \mathrm{H}_{2} \mathrm{O}(0.35 \mathrm{~g}, 1.5 \mathrm{mmol})$, and a catalyst solution $\left(\mathrm{Pd}(\mathrm{OAc})_{2}(2.2 \mathrm{mg}, 3 \mathrm{~mol} \%)\right.$ and S-Phos $(8.1 \mathrm{mg}, 6 \mathrm{~mol} \%)$ in $\mathrm{PhMe}(1.5 \mathrm{~mL}))$ was heated at $100{ }^{\circ} \mathrm{C}$ for $11 \mathrm{~h}$. After an aqueous workup, the crude material was purified by flash chromatography (2.5\% EtOAc in hexanes) to afford a white solid (0.092 g, 79\%). $\mathrm{R}_{\mathrm{f}}=0.22\left(2.5 \%\right.$ EtOAc in hexanes). $\mathrm{mp} 124-125^{\circ} \mathrm{C}$. IR (neat, $\left.\mathrm{cm}^{-1}\right)$ : 3052, 2935, 1613, 1509, 1456, 1363, 1323, 1249, 1173, 1126, 1067. ${ }^{1} \mathrm{H}$ NMR (400 $\left.\mathrm{MHz}, \mathrm{CDCl}_{3}\right) \delta$ 7.66-7.63 (1H, m), $7.59(2 \mathrm{H}, \mathrm{d}, J=8.1 \mathrm{~Hz}), 7.34-7.31(1 \mathrm{H}, \mathrm{m}), 7.26(2 \mathrm{H}$, d, $J=8.3 \mathrm{~Hz}), 7.22-7.18(2 \mathrm{H}, \mathrm{m}), 7.12-7.08(2 \mathrm{H}, \mathrm{m}), 6.85-6.82(2 \mathrm{H}, \mathrm{m}), 3.79(3 \mathrm{H}, \mathrm{s})$, $2.37(3 \mathrm{H}, \mathrm{s}) .{ }^{13} \mathrm{C}$ NMR $\left(100 \mathrm{MHz}, \mathrm{CDCl}_{3}\right) \delta 158.9,142.0,137.0,136.4,131.7,129.5$, $128.2\left(\mathrm{q}, J_{\mathrm{C}-\mathrm{F}}=32.2 \mathrm{~Hz}\right), 127.7,126.2\left(\mathrm{q}, J_{\mathrm{C}-\mathrm{F}}=3.6 \mathrm{~Hz}\right), 124.0\left(\mathrm{q}, J_{\mathrm{C}-\mathrm{F}}=272 \mathrm{~Hz}\right), 123.9$, 122.7, 120.6, 119.0, 113.8, 111.4, 109.9, 55.2, 9.5. ${ }^{19} \mathrm{~F}$ NMR (376 MHz, $\left.\mathrm{CDCl}_{3}\right) \delta-62.3$. HRMS (ESI) calc'd for $\mathrm{C}_{23} \mathrm{H}_{19} \mathrm{NOF}_{3}\left([\mathrm{M}+\mathrm{H}]^{+}\right)$382.1413. Found: 382.1417 .

\section{3-Methyl-2-phenyl-1-o-tolyl-1H-indole (27e)}




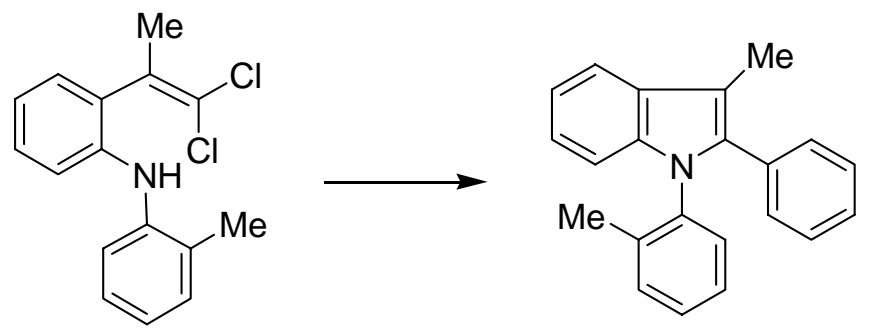

General procedure A for the Pd-catalyzed tandem coupling was followed. A mixture of [2-(2,2-dichloro-1-methylvinyl)-phenyl]-o-tolyl-amine $\quad(0.088 \quad \mathrm{~g}, \quad 0.30 \mathrm{mmol})$, $\mathrm{PhB}(\mathrm{OH})_{2}(0.055 \mathrm{~g}, 0.45 \mathrm{mmol}), \mathrm{K}_{3} \mathrm{PO}_{4} \cdot \mathrm{H}_{2} \mathrm{O}(0.35 \mathrm{~g}, 1.5 \mathrm{mmol})$, and a catalyst solution $\left(\mathrm{Pd}(\mathrm{OAc})_{2}(2.2 \mathrm{mg}, 3 \mathrm{~mol} \%)\right.$ and S-Phos $(8.1 \mathrm{mg}, 6 \mathrm{~mol} \%)$ in $\left.\mathrm{PhMe}(1.5 \mathrm{~mL})\right)$ was heated at $100{ }^{\circ} \mathrm{C}$ for $2.5 \mathrm{~h}$. After an aqueous workup, the crude material was purified by flash chromatography (2.5\% EtOAc in hexanes) to afford a white solid $(0.0684 \mathrm{~g}, 77 \%)$. $\mathrm{R}_{\mathrm{f}}=0.28$ (2.5\% EtOAc in hexanes). mp 106-107 ${ }^{\circ} \mathrm{C}$. IR (neat, $\mathrm{cm}^{-1}$ ): 3051, 2917, 1603, 1493, 1457, 1359, 1225. ${ }^{1} \mathrm{H}$ NMR (400 MHz, $\left.\mathrm{CDCl}_{3}\right) \delta$ 7.69-7.64 (1H, m), 7.26-7.14 $(11 \mathrm{H}, \mathrm{m}), 6.94-6.90(1 \mathrm{H}, \mathrm{m}), 2.43(3 \mathrm{H}, \mathrm{s}), 1.88(3 \mathrm{H}, \mathrm{s}) .{ }^{13} \mathrm{C} \mathrm{NMR}\left(100 \mathrm{MHz}, \mathrm{CDCl}_{3}\right) \delta$ $137.8,137.8,137.7,137.1,132.3,131.1,130.4,130.0,129.1,128.2$, 128.1, 127.3, 126.7, $122.5,119.9,119.0,110.7,109.9,17.9,9.9$. HRMS (EI) calc'd for $\mathrm{C}_{22} \mathrm{H}_{19} \mathrm{~N}\left([\mathrm{M}]^{+}\right)$ 297.1518. Found: 297.1511.

\section{1-[4-(3-Methyl-2-o-tolylindol-1-yl)phenyl]ethanone (27d)}

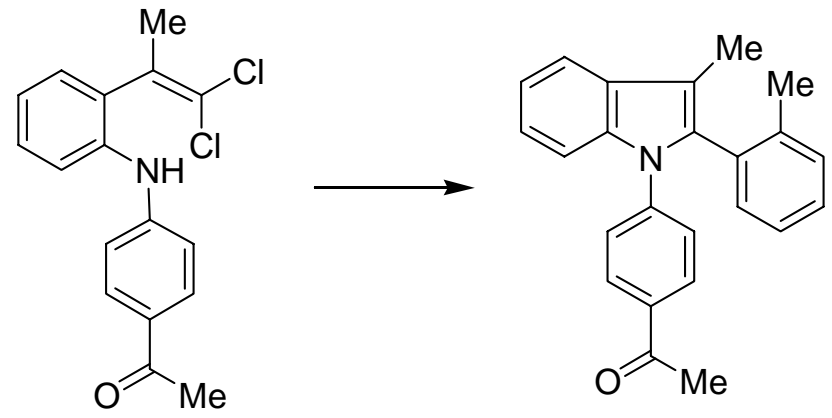

General procedure $\mathrm{C}$ for the Pd-catalyzed tandem coupling was followed. A mixture of 1-\{4-[2-(2,2-dichloro-1-methylvinyl)-phenylamino]-phenyl $\}$-ethanone $(0.096 \mathrm{~g}, 0.30$ mmol), 2-MePhB(OH $)_{2}(0.061 \mathrm{~g}, 0.45 \mathrm{mmol})$, a powdered mixture of $\mathrm{K}_{3} \mathrm{PO}_{4} \cdot \mathrm{H}_{2} \mathrm{O} / \mathrm{KOH}$ $(\mathrm{mol} / \mathrm{mol}=1: 2,0.108 \mathrm{~g}, 0.9 \mathrm{mmol})$, and a catalyst solution $\left(\mathrm{Pd}(\mathrm{OAc})_{2}(2.2 \mathrm{mg}, 3 \mathrm{~mol} \%)\right.$ and S-Phos $(8.1 \mathrm{mg}, 6 \mathrm{~mol} \%)$ in PhMe $(1.5 \mathrm{~mL}))$ was heated at $100{ }^{\circ} \mathrm{C}$ for $3 \mathrm{~h}$. After an aqueous workup, the crude material was purified by flash chromatography $(10 \%$ EtOAc 
in hexanes) to afford a white solid $(0.076 \mathrm{~g}, 75 \%) . \mathrm{R}_{\mathrm{f}}=0.21$ (10\% EtOAc in hexanes). mp 138-139 ${ }^{\circ} \mathrm{C}$. IR (neat, $\mathrm{cm}^{-1}$ ): 3055, 2917, 1683, 1599, 1455, 1362, 1266. ${ }^{1} \mathrm{H}$ NMR $\left(400 \mathrm{MHz}, \mathrm{CDCl}_{3}\right) \delta$ 7.88-7.85 (2H, m), 7.68-7.64 (1H, m), 7.45-7.40 (1H, m), 7.26-7.20 $(5 \mathrm{H}, \mathrm{m}), 7.19-7.14(3 \mathrm{H}, \mathrm{m}), 2.55(3 \mathrm{H}, \mathrm{s}), 2.21(3 \mathrm{H}, \mathrm{s}), 2.00(3 \mathrm{H}, \mathrm{s}) .{ }^{13} \mathrm{C} \mathrm{NMR}(100 \mathrm{MHz}$, $\left.\mathrm{CDCl}_{3}\right) \delta 197.3,142.9,138.4,136.8,136.5,134.7,132.0,131.7,130.3,129.5,129.3$, $128.7,126.7,125.7,122.8,120.8,119.2,112.3,110.4,26.7,20.0,9.5$. HRMS (ESI) calc'd for $\mathrm{C}_{24} \mathrm{H}_{22} \mathrm{NO}\left([\mathrm{M}+\mathrm{H}]^{+}\right)$340.1695. Found: 340.1711 .

\section{2-(3,4-Dimethoxyphenyl)-1-phenyl-1H-indole (26e)}

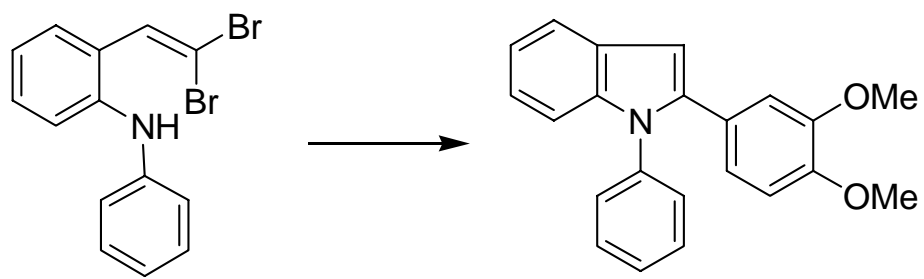

General procedure $\mathrm{C}$ for the Pd-catalyzed tandem coupling was followed. A mixture of [2-(2,2-dibromovinyl)-phenyl]-phenylamine $\quad\left(\begin{array}{lllll}0.106 & \mathrm{~g}, & 0.30 & \mathrm{mmol}), & 3,4-\end{array}\right.$ $(\mathrm{MeO})_{2} \mathrm{PhB}(\mathrm{OH})_{2}(0.082 \mathrm{~g}, 0.45 \mathrm{mmol})$, a powdered mixture of $\mathrm{K}_{3} \mathrm{PO}_{4} \cdot \mathrm{H}_{2} \mathrm{O} / \mathrm{KOH}$ $(\mathrm{mol} / \mathrm{mol}=1: 2,0.108 \mathrm{~g}, 0.9 \mathrm{mmol})$, and a catalyst solution $\left(\mathrm{Pd}(\mathrm{OAc})_{2}(2.2 \mathrm{mg}, 3 \mathrm{~mol} \%)\right.$ and S-Phos $(8.1 \mathrm{mg}, 6 \mathrm{~mol} \%)$ in PhMe $(1.5 \mathrm{~mL}))$ was heated at $100{ }^{\circ} \mathrm{C}$ for $5 \mathrm{~h}$. After an aqueous workup, the crude material was purified by flash chromatography $(20 \% \mathrm{EtOAc}$ in hexanes) to afford a white solid $(0.060 \mathrm{~g}, 60 \%) . \mathrm{R}_{\mathrm{f}}=0.22$ (20\% EtOAc in hexanes). mp 113-115 ${ }^{\circ} \mathrm{C}$. IR (neat, $\mathrm{cm}^{-1}$ ): 3057, 2934, 1596, 1502, 1454, 1247, 1224, 1140, 1025. ${ }^{1} \mathrm{H}$ NMR $\left(400 \mathrm{MHz}, \mathrm{CDCl}_{3}\right) \delta$ 7.68-7.64 (1H, m), 7.44-7.40 (2H, m), 7.36-7.32 (1H, m), 7.28-7.25 (3H, m), 7.18-7.13 (2H, m), $6.94(1 \mathrm{H}, \mathrm{dd}, J=8.3,2.0 \mathrm{~Hz}), 6.77(1 \mathrm{H}, \mathrm{d}, J=9.2$ $\mathrm{Hz}), 6.76(1 \mathrm{H}, \mathrm{s}), 6.65(1 \mathrm{H}, \mathrm{d}, J=2.0 \mathrm{~Hz}), 3.85(3 \mathrm{H}, \mathrm{s}), 3.57(3 \mathrm{H}, \mathrm{s}) .{ }^{13} \mathrm{C}$ NMR $(100$ $\left.\mathrm{MHz}, \mathrm{CDCl}_{3}\right) \delta 148.6,148.5,140.8,139.0,138.9,129.5,128.5,128.4,127.4,125.4$, 122.3, 121.7, 120.9, 120.5, 112.4, 111.1, 110.7, 102.9, 56.0, 55.7. HRMS (EI) calc'd for $\mathrm{C}_{22} \mathrm{H}_{19} \mathrm{NO}_{2}\left([\mathrm{M}]^{+}\right)$329.1416. Found: 329.1424.

\section{1,3-Dimethyl-5-nitro-2-phenyl-1H-indole (27f)}




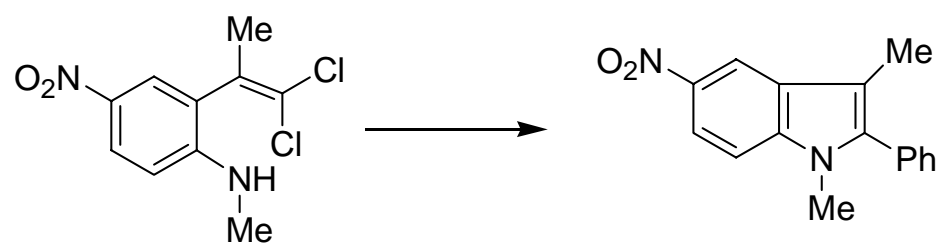

General procedure A for the Pd-catalyzed tandem coupling was followed using 23 (46.4 mg, $0.178 \mathrm{mmol}), \mathrm{PhB}(\mathrm{OH})_{2}(32.5 \mathrm{mg}, 0.267 \mathrm{mmol}), \mathrm{K}_{3} \mathrm{PO}_{4} \cdot \mathrm{H}_{2} \mathrm{O}(0.205 \mathrm{mg}, 0.89$ mmol), $\mathrm{Pd}(\mathrm{OAc})_{2}(3 \mathrm{~mol} \%)$, and S-Phos $(6 \mathrm{~mol} \%)$. After heating at $100{ }^{\circ} \mathrm{C}$ for $1 \mathrm{~h}$, the product was obtained as a yellow solid using flash chromatography (22.3 mg, 85\%). mp 138-139 ${ }^{\circ} \mathrm{C}$. IR (neat, $\mathrm{cm}^{-1}$ ): 2944, 1512, 1498, 1337. ${ }^{1} \mathrm{H}$ NMR (400 MHz, $\left.\mathrm{CDCl}_{3}\right) \delta 8.57$ $(1 \mathrm{H}, \mathrm{d}, J=2.2 \mathrm{~Hz}), 8.15(1 \mathrm{H}, \mathrm{dd}, J=9.0,2.2 \mathrm{~Hz}), 7.55-7.43(3 \mathrm{H}, \mathrm{m}), 7.41-7.39(2 \mathrm{H}, \mathrm{m})$, $7.33(1 \mathrm{H}, \mathrm{d}, J=9.0 \mathrm{~Hz}), 3.66(3 \mathrm{H}, \mathrm{s}), 2.30(3 \mathrm{H}, \mathrm{s}) .{ }^{13} \mathrm{C} \mathrm{NMR}\left(100 \mathrm{MHz}, \mathrm{CDCl}_{3}\right) \delta 141.5$, $140.9,140.1,131.0,130.7,128.9,128.0,117.6,116.4,111.5,109.2,31.6,9.4$. HRMS (ESI) calc'd for $\mathrm{C}_{16} \mathrm{H}_{15} \mathrm{~N}_{2} \mathrm{O}_{2}\left([\mathrm{M}+\mathrm{H}]^{+}\right)$267.1128. Found: 267.1132.

\section{Mechanistic Evidence for Pd-Catalyzed Tandem C-N/C-C Couplings 2-Phenyl-1H-indole (17a)}

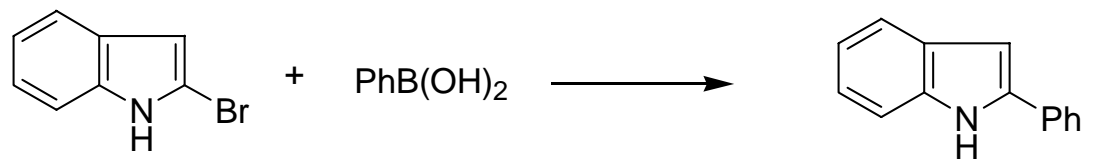

General procedure A for the Pd-catalyzed tandem coupling was followed using 2bromoindole (0.098, $0.5 \mathrm{mmol}), \mathrm{PhB}(\mathrm{OH})_{2}(0.092 \mathrm{~g}, 0.75 \mathrm{mmol}), \mathrm{K}_{3} \mathrm{PO}_{4} \cdot \mathrm{H}_{2} \mathrm{O}(0.230 \mathrm{~g}, 1$ $\mathrm{mmol}), \mathrm{Pd}(\mathrm{OAc})_{2}(1.2 \mathrm{mg}, 1 \mathrm{~mol} \%)$, and S-Phos (4.1 mg, $\left.2 \mathrm{~mol} \%\right)$. After heating at 90 ${ }^{\circ} \mathrm{C}$ for $1 \mathrm{~h}, 2$-phenylindole was obtained as a white solid using flash chromatography (0.096 mg, 99\%).

\section{Deuterated 2-nitrobenzaldehyde (33)}
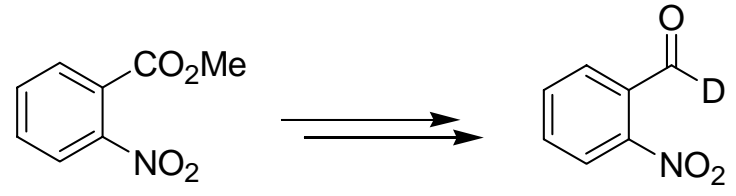

To a suspension of methyl 2-nitrobenzoate (2.72 g, $15 \mathrm{mmol})$ in $\mathrm{Et}_{2} \mathrm{O}(45 \mathrm{~mL})$ was added $\mathrm{LiAlH}_{4}(0.336 \mathrm{~g}, 8 \mathrm{mmol})$ in several portions at $0{ }^{\circ} \mathrm{C}$. After addition, the mixture was stirred at $0{ }^{\circ} \mathrm{C}$ for another $2 \mathrm{~h}$ before quenched by pouring into $\mathrm{HCl}(1 \mathrm{M}, 50 \mathrm{~mL})$. 
The resulting mixture was extracted with $\mathrm{Et}_{2} \mathrm{O}(2 \times 30 \mathrm{~mL})$, washed with $\mathrm{NaHCO}_{3}(10$ $\mathrm{mL})$, brine $(10 \mathrm{~mL})$, and dried over $\mathrm{MgSO}_{4}$. The crude material was chromatographed with $25 \%$ EtOAc in hexanes to afford the benzyl alcohol as a brown solid, which was directly used in next step (0.76 g, 33\%).

The benzyl alcohol $(0.75 \mathrm{~g})$ solution in DCM $(15 \mathrm{~mL})$ was added PCC $(1.6 \mathrm{~g})$, and the mixture was stirred at rt overnight. Celite was added to the reaction, and the resulting mixture was filtered through a celite pad. After the celite was washed with DCM (20 $\mathrm{mL}$ ), the combined organic was evaporated and chromatographed with $20 \%$ EtOAc in hexanes to give the deuterated 2-nitrobenzaldehyde as a slightly yellow solid $(0.595 \mathrm{~g}$, $80 \%)$.

\section{2-(2,2-Dibromo-1-deuterovinyl)-phenylamine (34)}

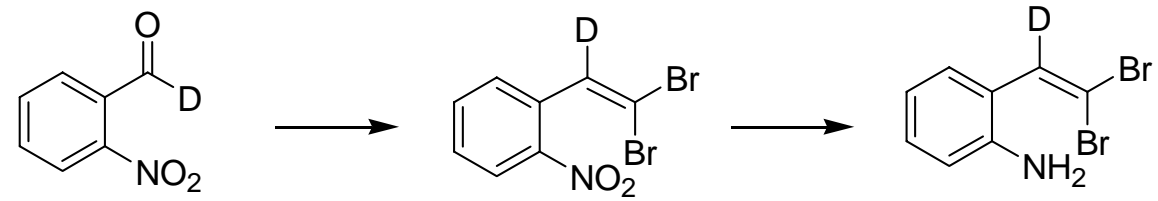

The general procedure for the preparation of 1a was followed using aldehyde $33(0.59$ g, $3.88 \mathrm{mmol}), \mathrm{CBr}_{4}(1.93 \mathrm{~g}, 5.82 \mathrm{mmol}), \mathrm{PPh}_{3}(3.05 \mathrm{~g}, 11.64 \mathrm{mmol})$, and $\mathrm{SnCl}_{2} \cdot 2 \mathrm{H}_{2} \mathrm{O}$ $(4.38 \mathrm{~g}, 19.4 \mathrm{mmol})$. The product was obtained as an off-white solid $(0.80 \mathrm{~g}, 74 \%$ over 2 steps). IR (neat, $\mathrm{cm}^{-1}$ ): 3459, 3377, 3024, 2226 (C-D strech), 1621, 1488, 1455, 1305, 1261, 1159. ${ }^{1} \mathrm{H}$ NMR $\left(400 \mathrm{MHz}, \mathrm{CDCl}_{3}\right) \delta 7.30(1 \mathrm{H}, \mathrm{dd}, J=7.7,1.5 \mathrm{~Hz}), 7.16(1 \mathrm{H}$, ddd, $J=7.7,7.7,1.5 \mathrm{~Hz}), 6.78(1 \mathrm{H}, \mathrm{ddd}, J=7.6,7.6,1.1 \mathrm{~Hz}), 6.70(1 \mathrm{H}, \mathrm{dd}, J=8.1,1.1 \mathrm{~Hz})$, $3.69\left(2 \mathrm{H}\right.$, br). ${ }^{13} \mathrm{C} \mathrm{NMR}\left(75 \mathrm{MHz}, \mathrm{CDCl}_{3}\right) \delta 143.9,134.0\left(\mathrm{t}, J_{\mathrm{C}-\mathrm{D}}=24.4 \mathrm{~Hz}\right), 123.0$, 129.4, 121.9, 118.6, 116.0, 93.0. HRMS (EI) calc'd for $\mathrm{C}_{8} \mathrm{H}_{6} \mathrm{DNBr}_{2}\left([\mathrm{M}]^{+}\right) 275.9008$. Found: 275.9011.

\section{3-Deutero-2-phenyl-1H-indole (36-1)}<smiles>[2H]C(=C(Br)Br)c1ccccc1N</smiles> 
General procedure A for the Pd-catalyzed tandem coupling was followed using 34 (0.141 g, $0.5 \mathrm{mmol}), \mathrm{PhB}(\mathrm{OH})_{2}(0.092 \mathrm{~g}, 0.75 \mathrm{mmol}), \mathrm{K}_{3} \mathrm{PO}_{4} \cdot \mathrm{H}_{2} \mathrm{O}(0.58 \mathrm{~g}, 2.5 \mathrm{mmol})$, $\mathrm{Pd}(\mathrm{OAc})_{2}(2 \mathrm{~mol} \%)$, and S-Phos (4 mol\%). After heating at $90{ }^{\circ} \mathrm{C}$ for $2 \mathrm{~h}$, the product was obtained as a white solid using flash chromatography $(0.083 \mathrm{~g}, 85 \%) .{ }^{1} \mathrm{H}$ NMR spectrum showed an integration of 0.16 at $\delta 6.82(3-\mathrm{H})$.

\section{3-Deutero-2-phenyl-1H-indole (36-2)}

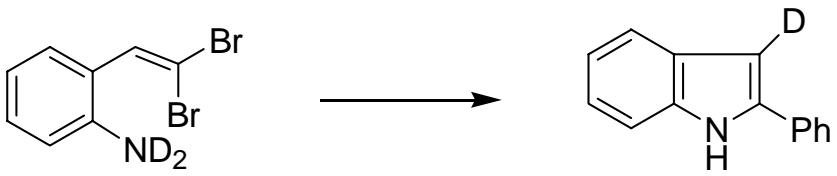

$\mathrm{K}_{3} \mathrm{PO}_{4} \cdot \mathrm{D}_{2} \mathrm{O}$ was obtained by mixing $\mathrm{K}_{3} \mathrm{PO}_{4}(1.06 \mathrm{~g})$ and $\mathrm{D}_{2} \mathrm{O}(100 \mu \mathrm{L})$, standing for 2 days. The solid was grounded into fine powder before use.

$N, N$-dideutero-2-(2,2-dibromovinyl)-phenylamine (35) was obtained by washing with $\mathrm{D}_{2} \mathrm{O}$ three times and dried over $\mathrm{Na}_{2} \mathrm{SO}_{4}$. ${ }^{1} \mathrm{H}$ NMR spectrum showed an integration of $<0.60$ at $\delta 3.70$ (NHD).

General procedure A for the Pd-catalyzed tandem coupling was followed using 35 (0.141 g, $0.5 \mathrm{mmol}), \mathrm{PhB}(\mathrm{OH})_{2}(0.092 \mathrm{~g}, 0.75 \mathrm{mmol}), \mathrm{K}_{3} \mathrm{PO}_{4} \cdot \mathrm{H}_{2} \mathrm{O}(0.58 \mathrm{~g}, 2.5 \mathrm{mmol})$, $\mathrm{Pd}(\mathrm{OAc})_{2}(2 \mathrm{~mol} \%)$, and S-Phos (4 mol\%). After heating at $90{ }^{\circ} \mathrm{C}$ for $2 \mathrm{~h}$, the product was obtained as a white solid using flash chromatography $(0.082 \mathrm{~g}, 84 \%) .{ }^{1} \mathrm{H}$ NMR spectrum showed an integration of 0.81 at $\delta 6.82(3-\mathrm{H})$.

\section{2-(2-Bromo-2-phenylvinyl)-phenylamine (28)}

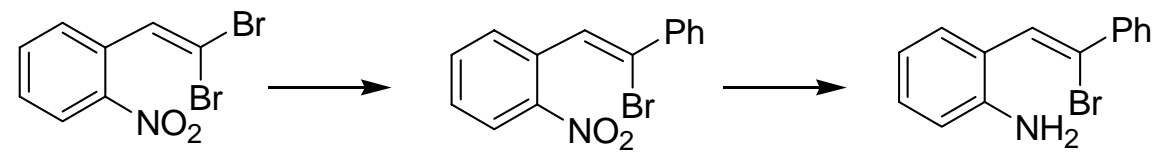

A mixture of 1-(2,2-dibromovinyl)-2-nitrobenzene (0.414 g, $1.35 \mathrm{mmol}), \mathrm{PhB}(\mathrm{OH})_{2}$ (0.173 g, $1.42 \mathrm{mmol}), \mathrm{Pd}_{2}(\mathrm{dba})_{3}(31 \mathrm{mg}, 0.034 \mathrm{mmol})$, and TFP $(47.4 \mathrm{mmol})$ in dioxane $(6 \mathrm{~mL})$ under argon was stirred at $\mathrm{rt}$ for $5 \mathrm{~min}$. An aqueous $\mathrm{Na}_{2} \mathrm{CO}_{3}$ solution $(1 \mathrm{M}, 2.75$ $\mathrm{mL}$ ) was added and the mixture was heated at $65^{\circ} \mathrm{C}$ for $5 \mathrm{~h}$. The mixture was evaporated and the residue was extracted with $\mathrm{Et}_{2} \mathrm{O}$, washed with brine, and dried over $\mathrm{MgSO}_{4}$. The 
residue after removal of solvent was chromatographed to give a crude intermediate (about $0.3 \mathrm{~g}$ ), which was directly subjected to the reduction. The crude intermediate and $\mathrm{SnCl}_{2} \cdot 2 \mathrm{H}_{2} \mathrm{O}(1.13 \mathrm{~g}, 5 \mathrm{mmol})$ in $\mathrm{EtOH}(95 \%, 15 \mathrm{~mL})$ was heated under argon for $1.5 \mathrm{~h}$. After most of the $\mathrm{EtOH}$ was removed, the residue was taken into $\mathrm{Et}_{2} \mathrm{O}$ and saturated $\mathrm{K}_{2} \mathrm{CO}_{3}$ solution. The mixture was extracted with $\mathrm{Et}_{2} \mathrm{O}$, washed with brine, and dried over $\mathrm{Na}_{2} \mathrm{SO}_{4}$. The crude material was purified by flash chromatography using $10 \%$ EtOAc in hexanes to 28 as an oil $\left(0.205 \mathrm{~g}, 55 \%\right.$ over 2 steps). IR (neat, $\left.\mathrm{cm}^{-1}\right): 3456,3377,3057$, 1614, 1495, 1455, 1444, 1310, 1228. ${ }^{1} \mathrm{H}$ NMR (400 MHz, $\left.\mathrm{CDCl}_{3}\right) \delta 8.69(2 \mathrm{H}, \mathrm{m}), 7.45$ $(1 \mathrm{H}, \mathrm{d}, J=7.7 \mathrm{~Hz}), 7.40-7.32(3 \mathrm{H}, \mathrm{m}), 7.15(1 \mathrm{H}, \mathrm{ddd}, J=7.2,7.2,1.5 \mathrm{~Hz}), 7.10(1 \mathrm{H}, \mathrm{s})$, $6.82(1 \mathrm{H}, \mathrm{ddd}, J=7.1,7.1,1.0 \mathrm{~Hz}), 6.73(1 \mathrm{H}, \mathrm{d}, J=8.1), 3.70(2 \mathrm{H}, \mathrm{br}) .{ }^{13} \mathrm{C}$ NMR $(100$ $\left.\mathrm{MHz}, \mathrm{CDCl}_{3}\right) \delta 144.3,140.2,129.8,129.4,129.1,128.6,127.9,127.8,126.7,123.1$, 118.4, 115.8. HRMS (EI) calc'd for $\mathrm{C}_{14} \mathrm{H}_{12} \mathrm{NBr}\left([\mathrm{M}]^{+}\right)$273.0153. Found: 273.0153.

\section{2-Phenyl-1H-indole (17a) and 2-(2,2-diphenylvinyl)-phenylamine (31)}

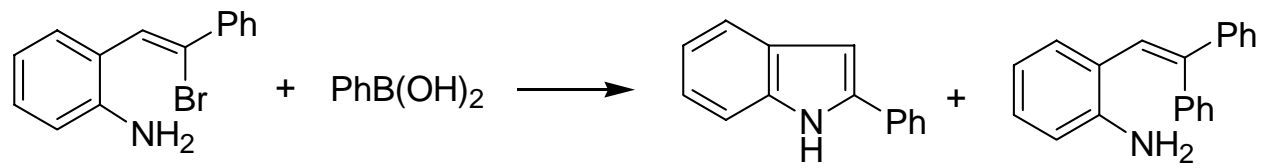

General procedure A for the Pd-catalyzed tandem coupling was followed using 28 (0.113 g, $0.412 \mathrm{mmol}), \mathrm{PhB}(\mathrm{OH})_{2}(0.049 \mathrm{~g}, 0.4 \mathrm{mmol}), \mathrm{K}_{3} \mathrm{PO}_{4} \cdot \mathrm{H}_{2} \mathrm{O}(0.46 \mathrm{~g}, 2 \mathrm{mmol})$, $\mathrm{Pd}(\mathrm{OAc})_{2}(2 \mathrm{~mol} \%)$, and S-Phos $(4 \mathrm{~mol} \%)$. After heating at $90{ }^{\circ} \mathrm{C}$ for $30 \mathrm{~min}$, the crude material was chromatographed with $5 \rightarrow 10 \%$ EtOAc in hexanes to give a pure sample of 17a (43 mg) and a mixed sample of 17a and 31 (34.4 mg, 1:1). The overall amount for 17a was $57.4 \mathrm{mg}(72 \%)$ and the amount for 31 was $20 \mathrm{mg}(18 \%)$. 
15c
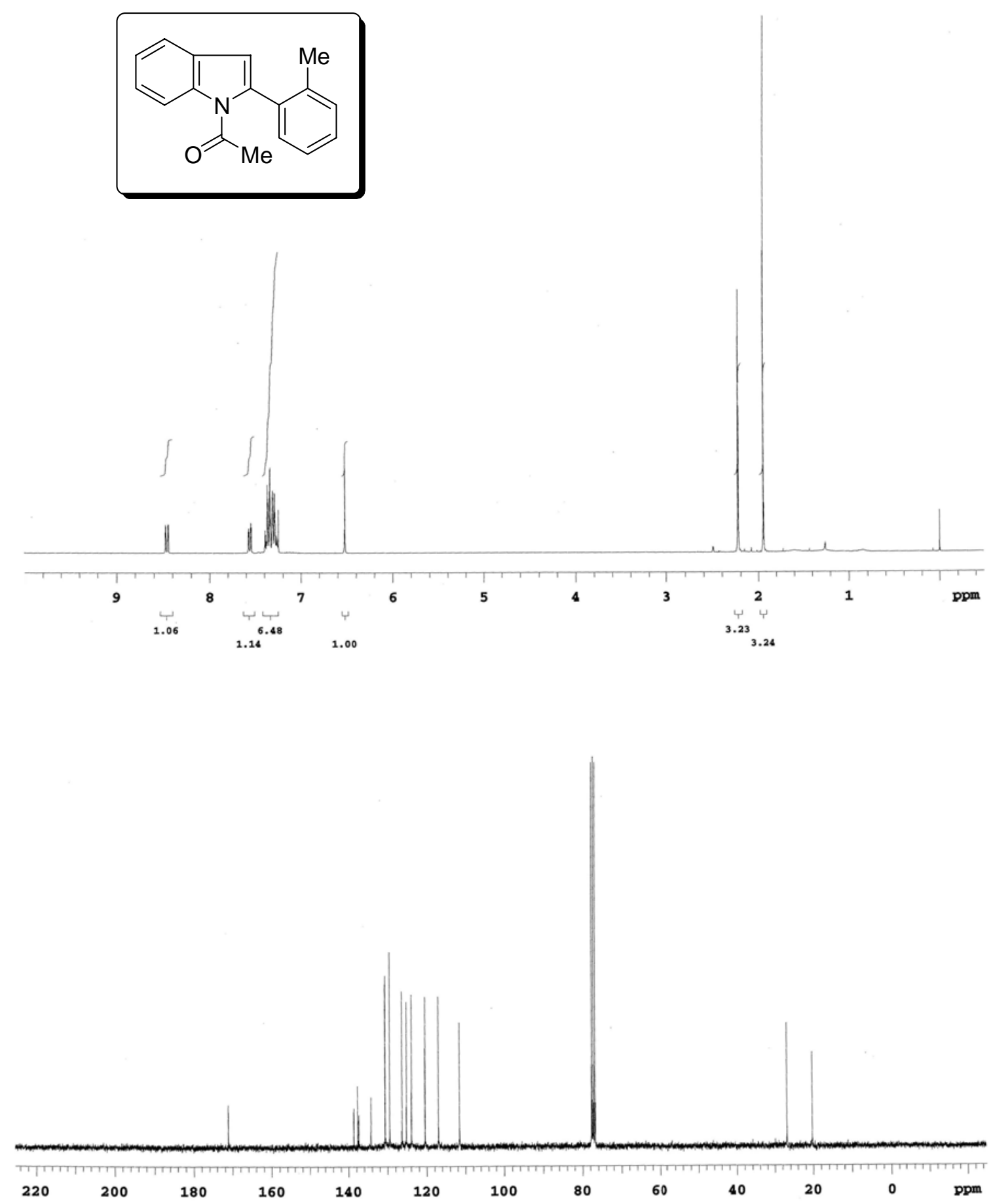
15b
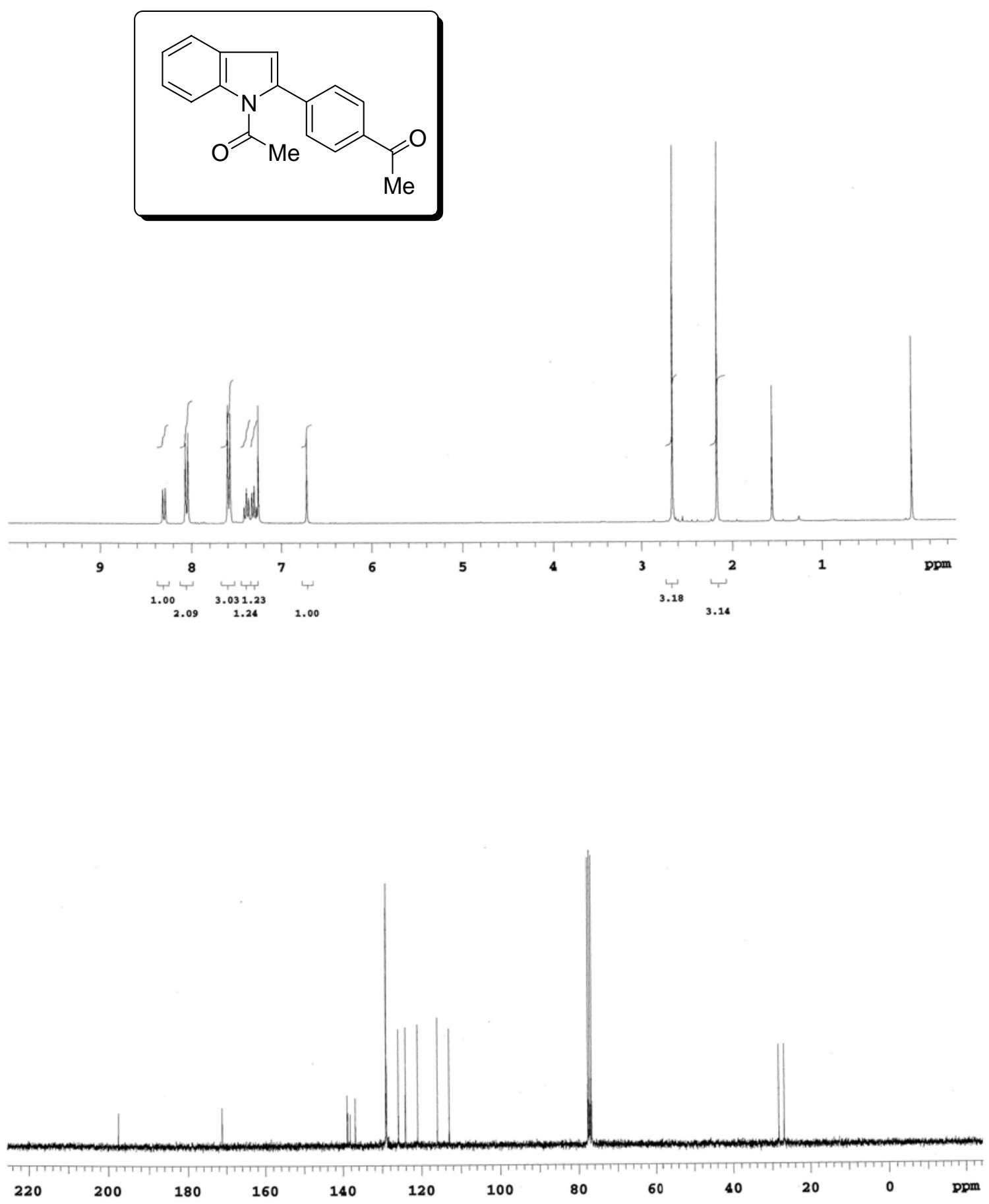
$1 b$
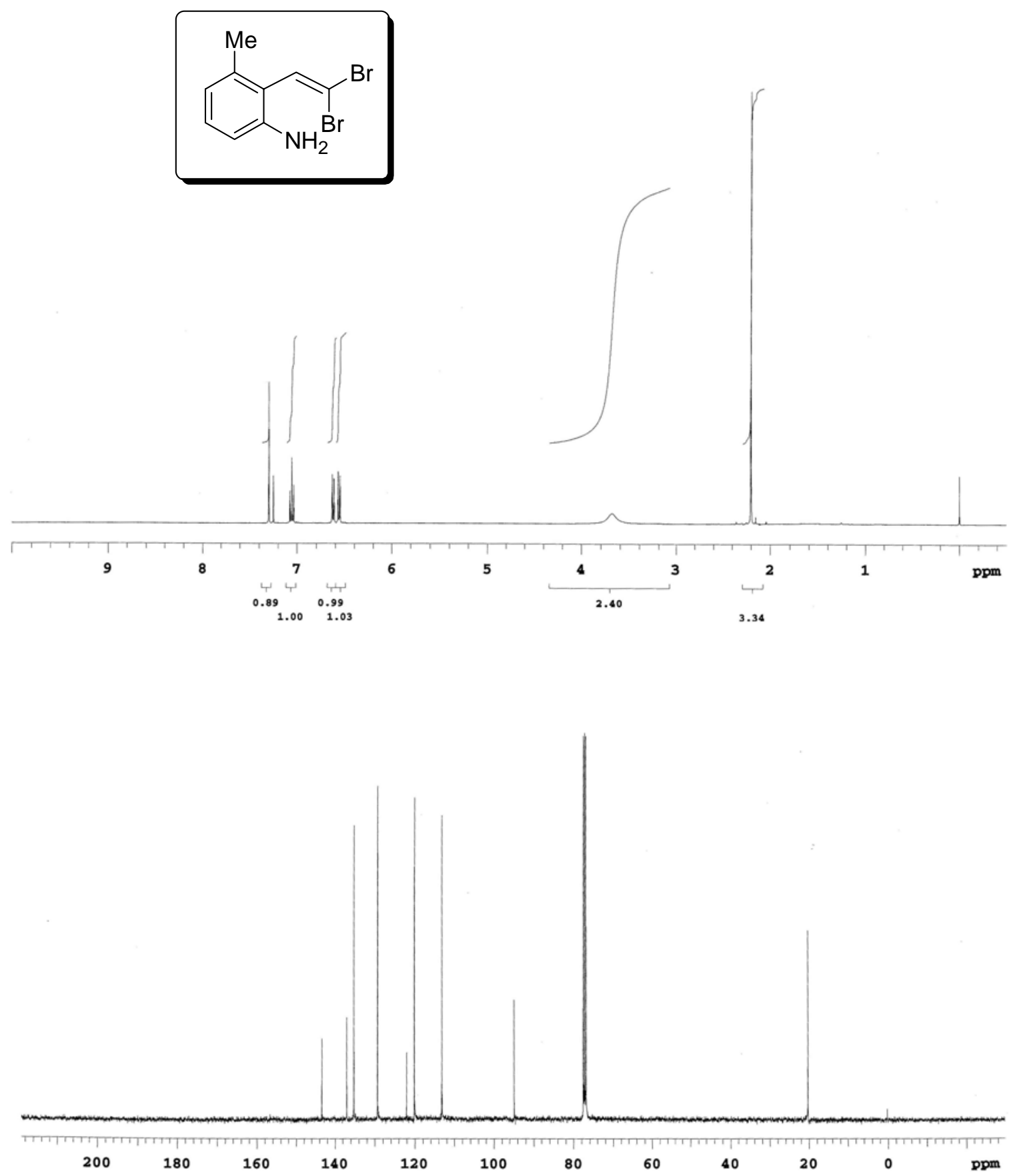

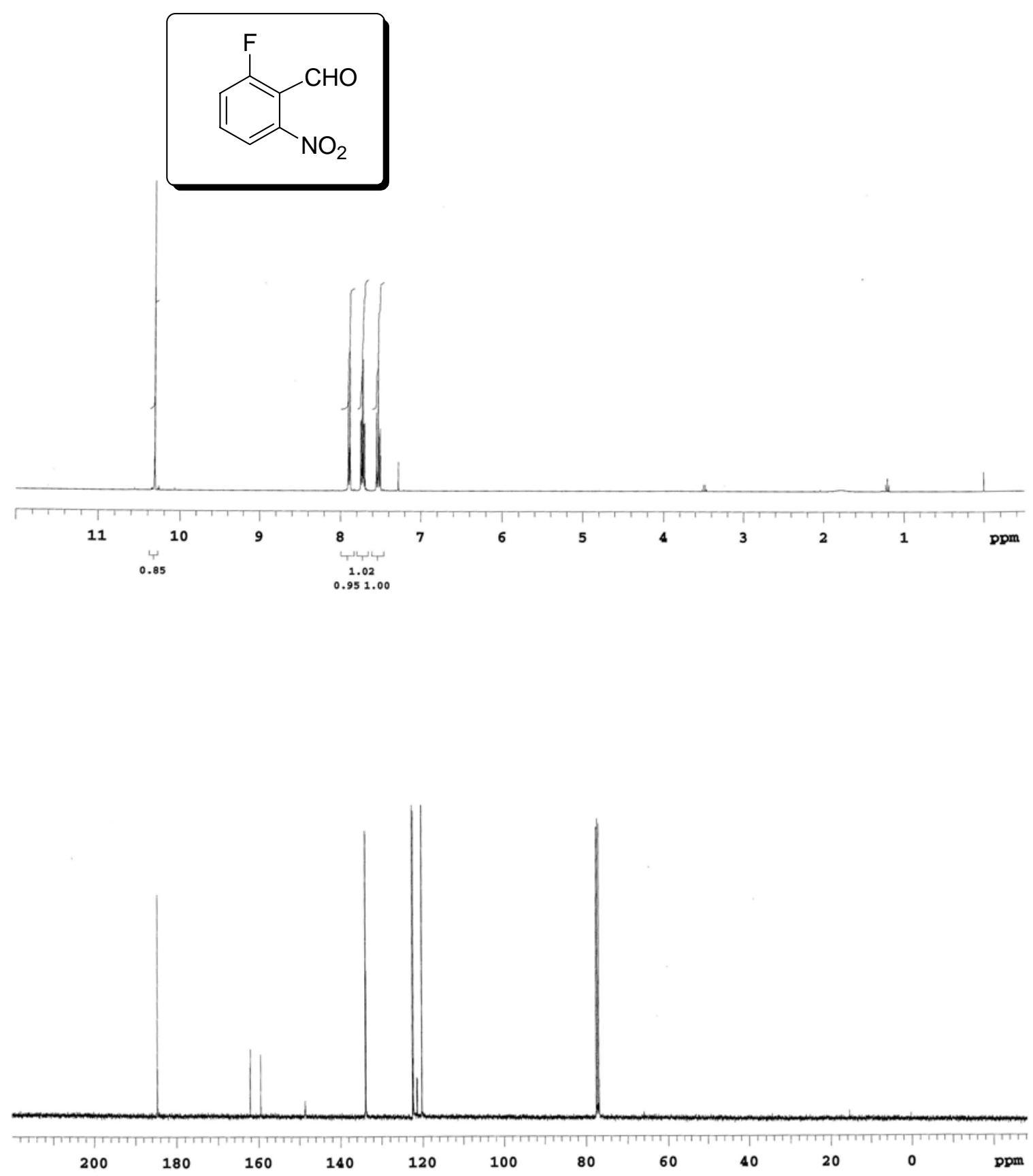
S61

1c
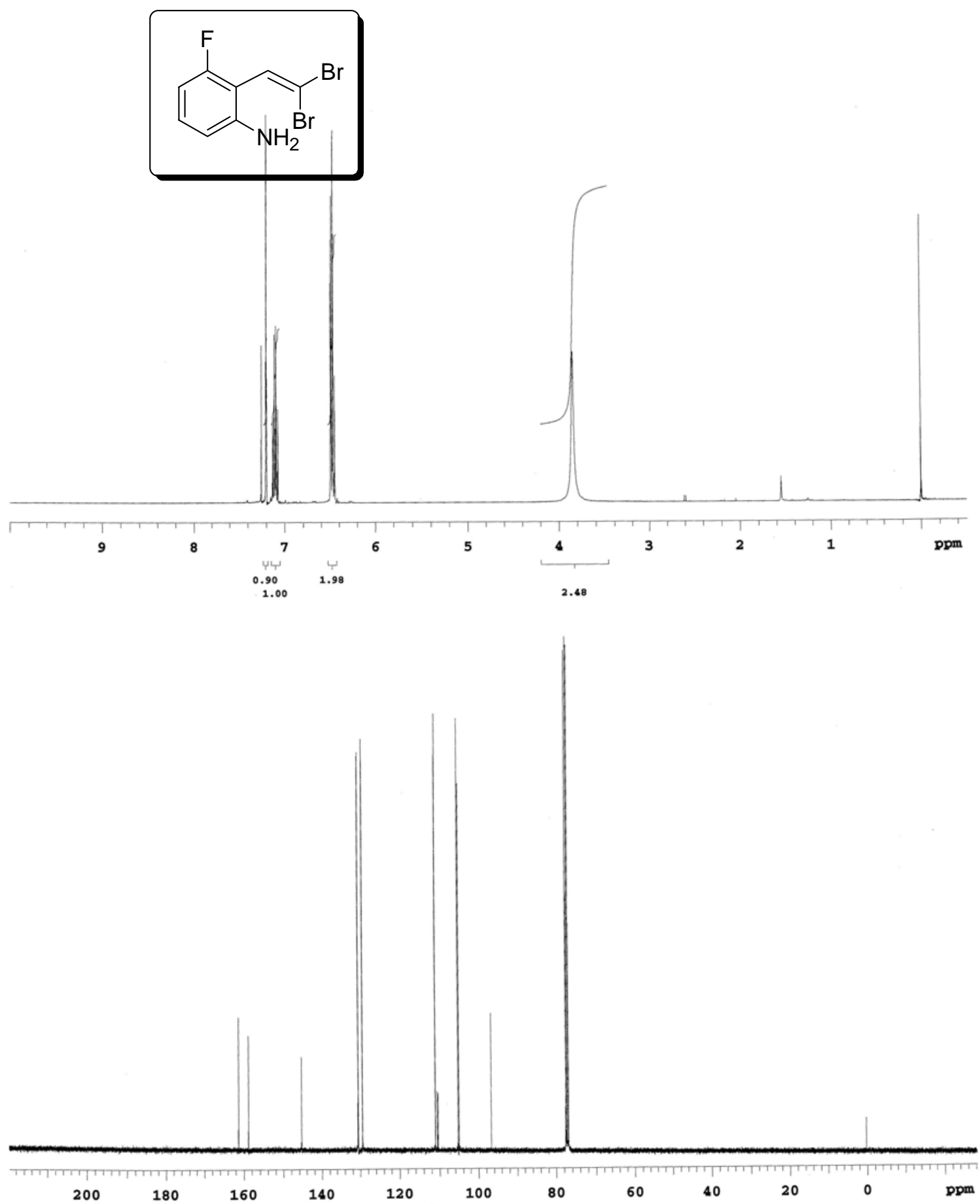
S62

1d
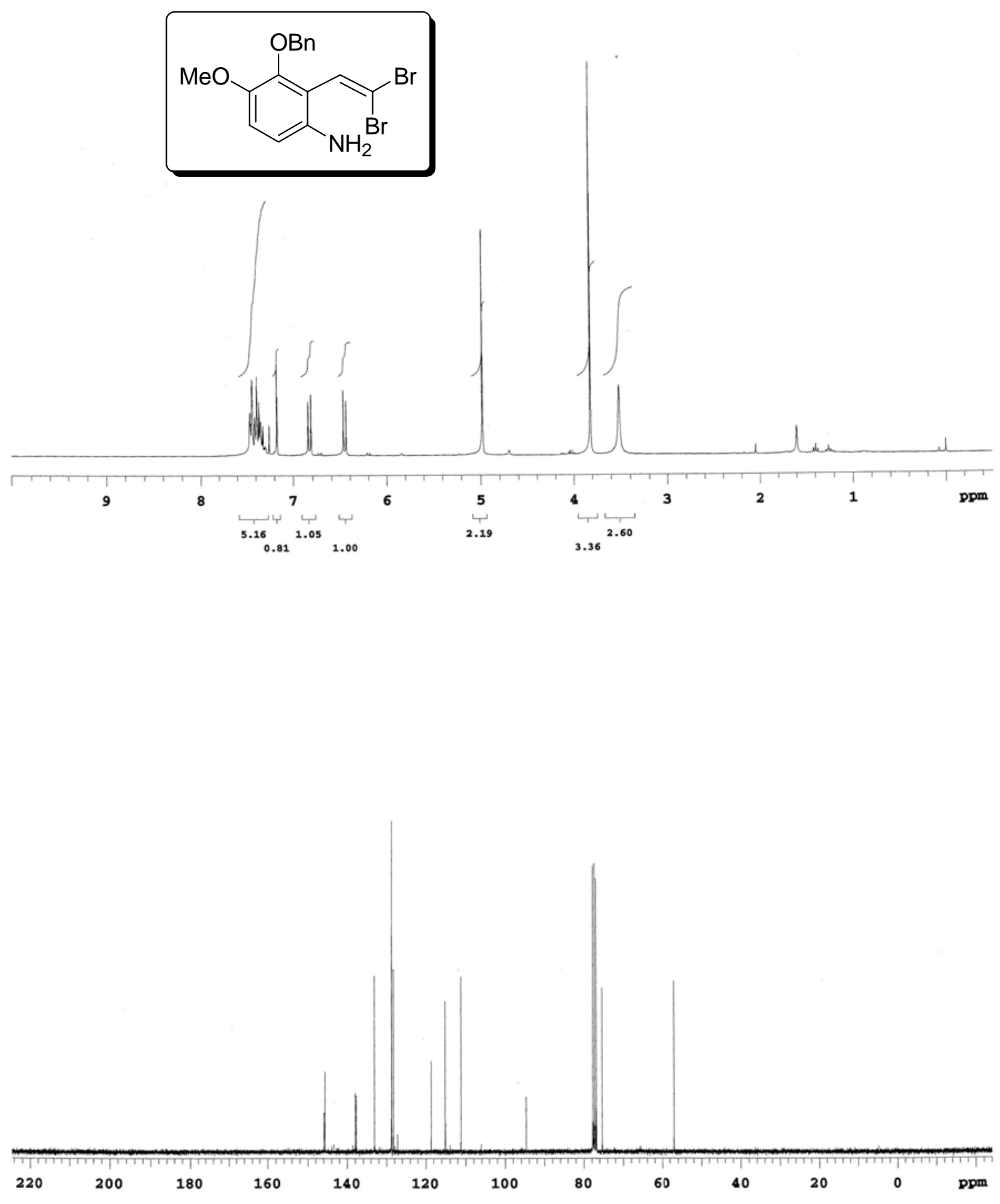
S63

1e
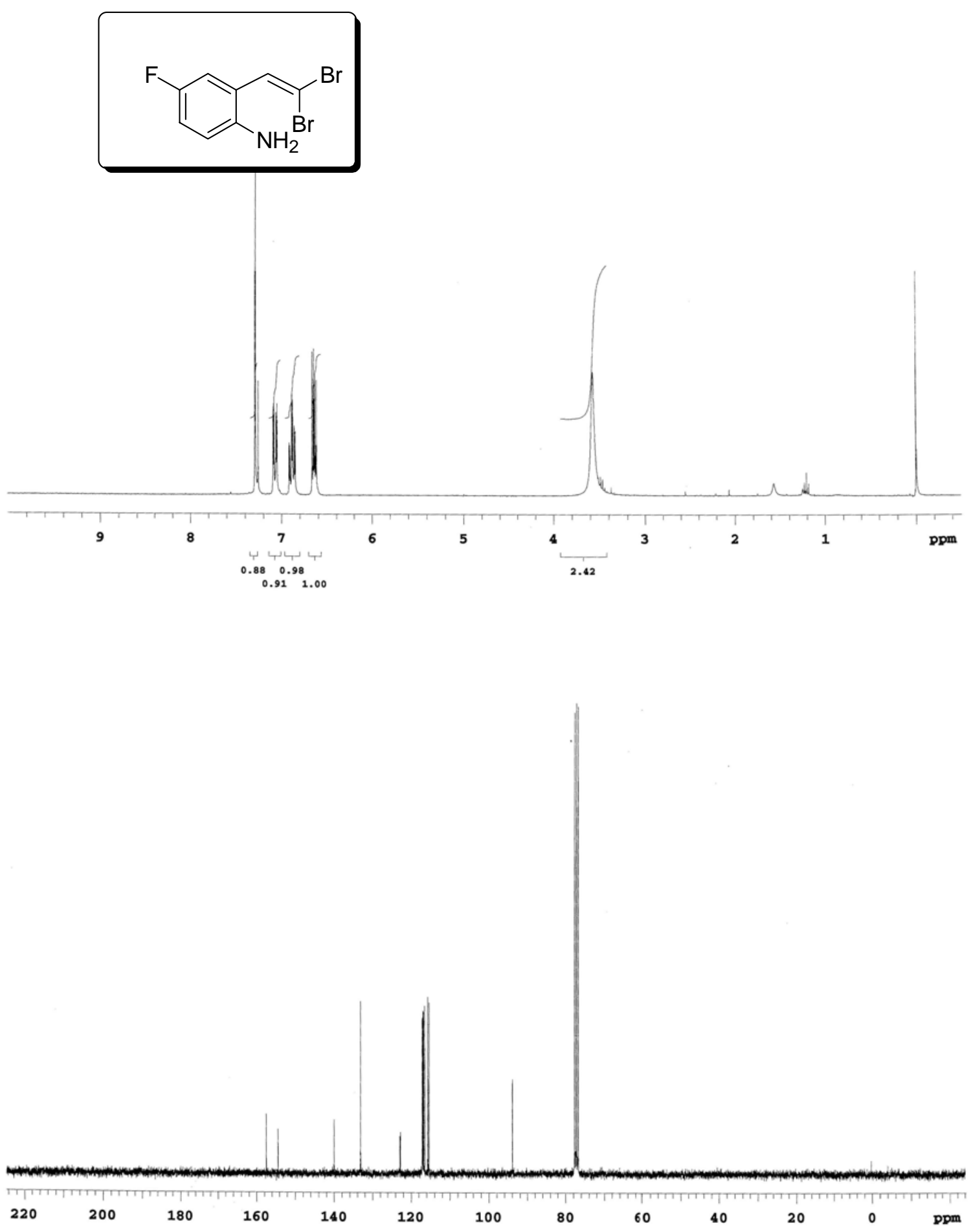
S64

1f
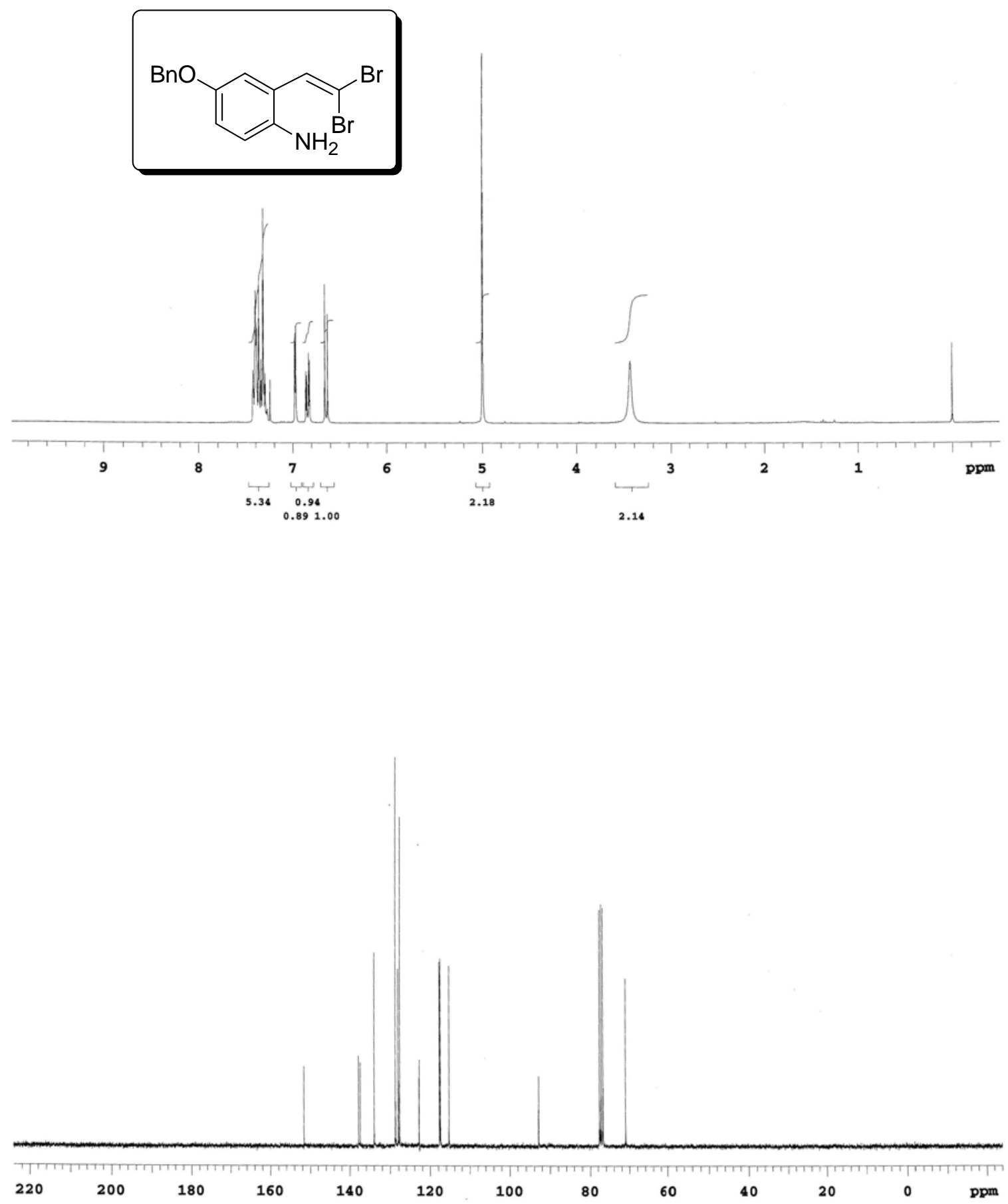
S65

$1 g$
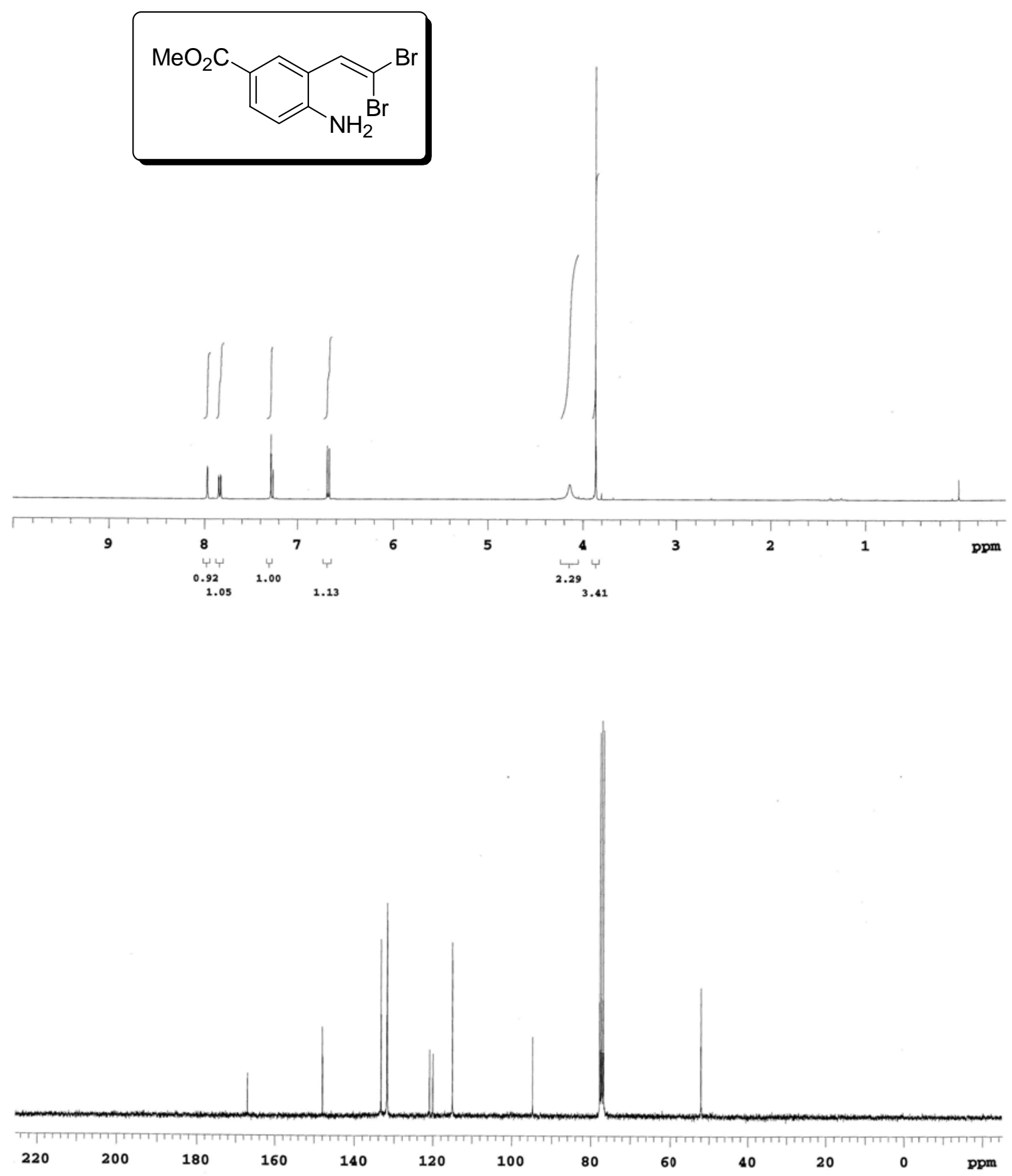
S66

1h
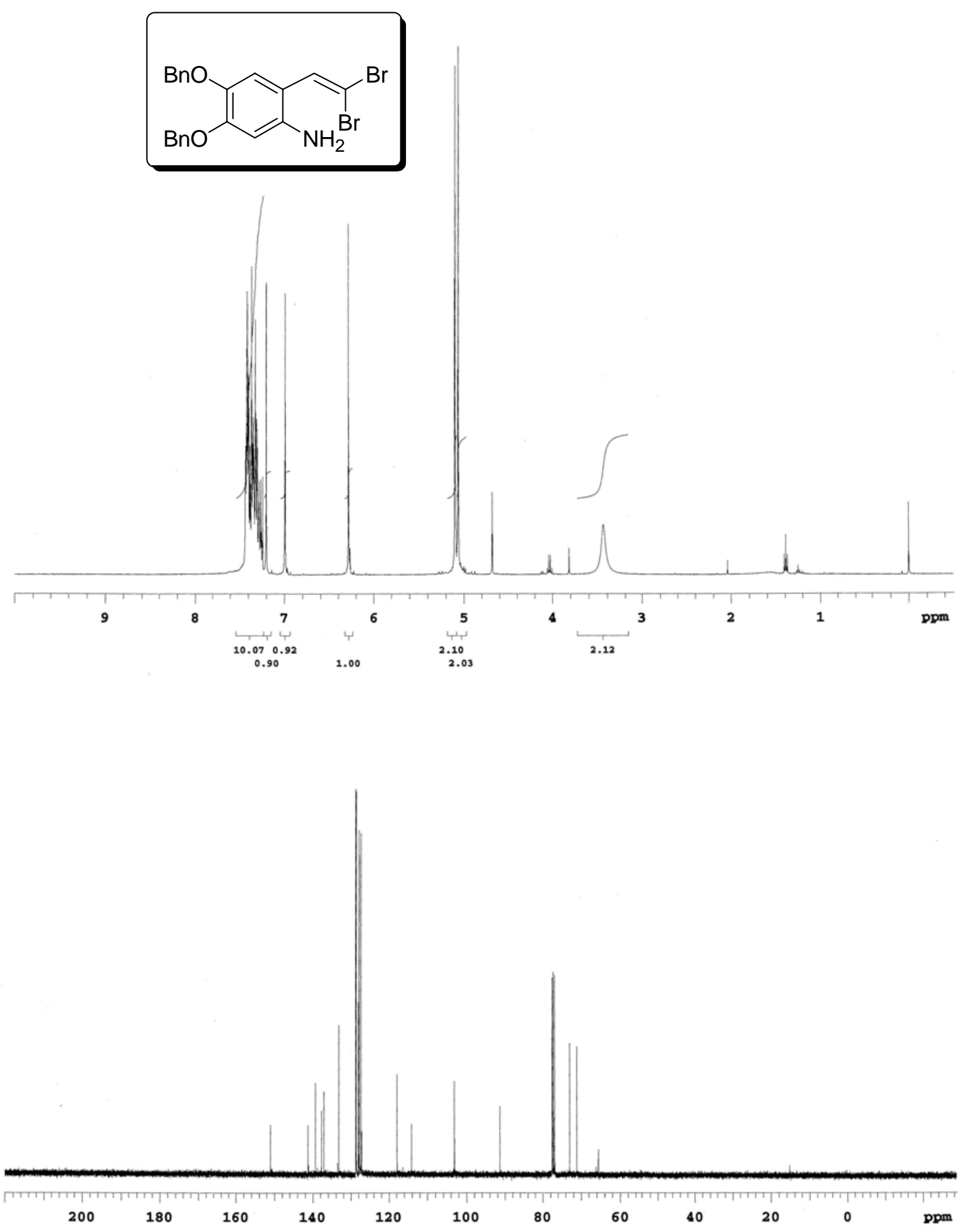
$1 i$
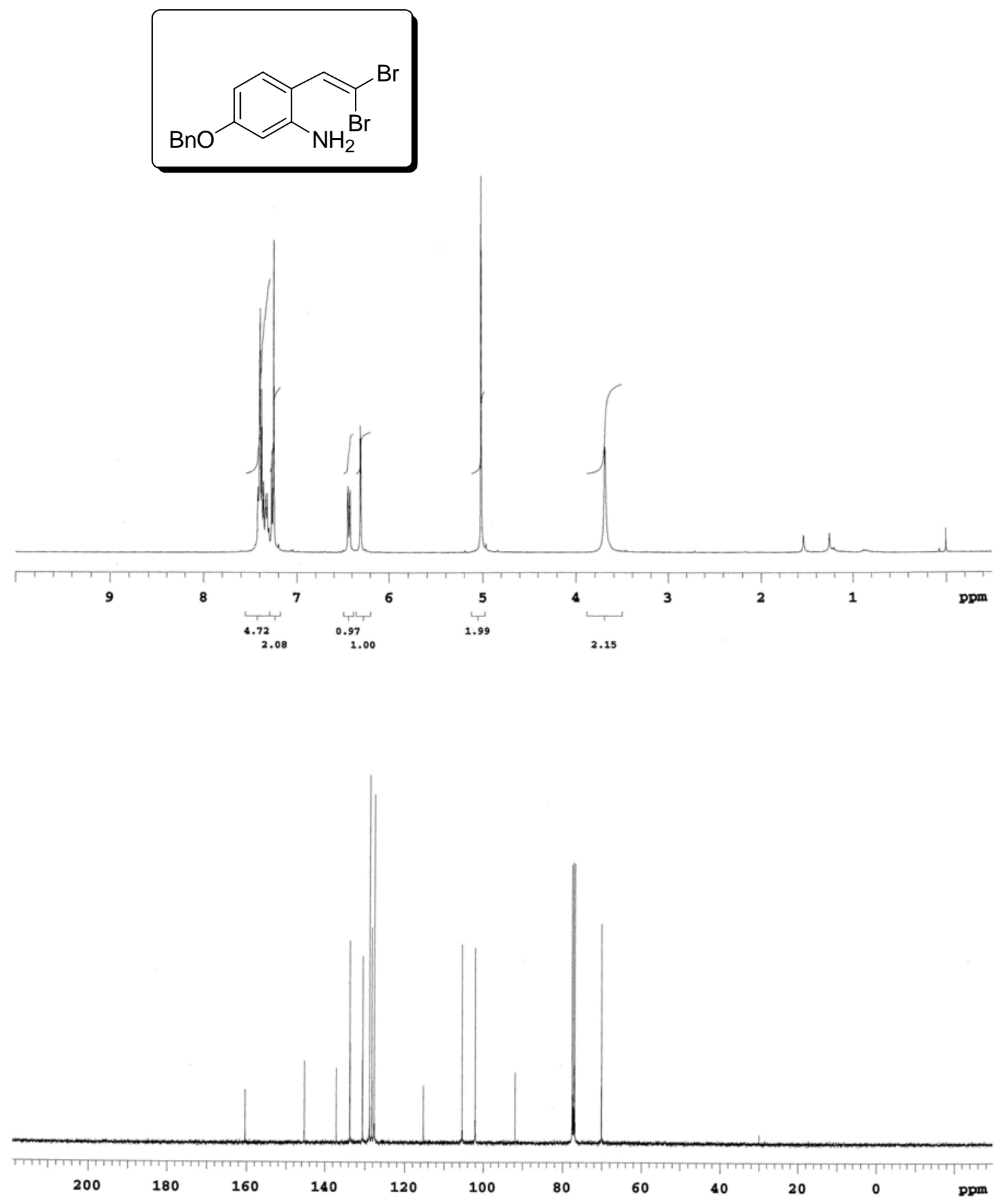

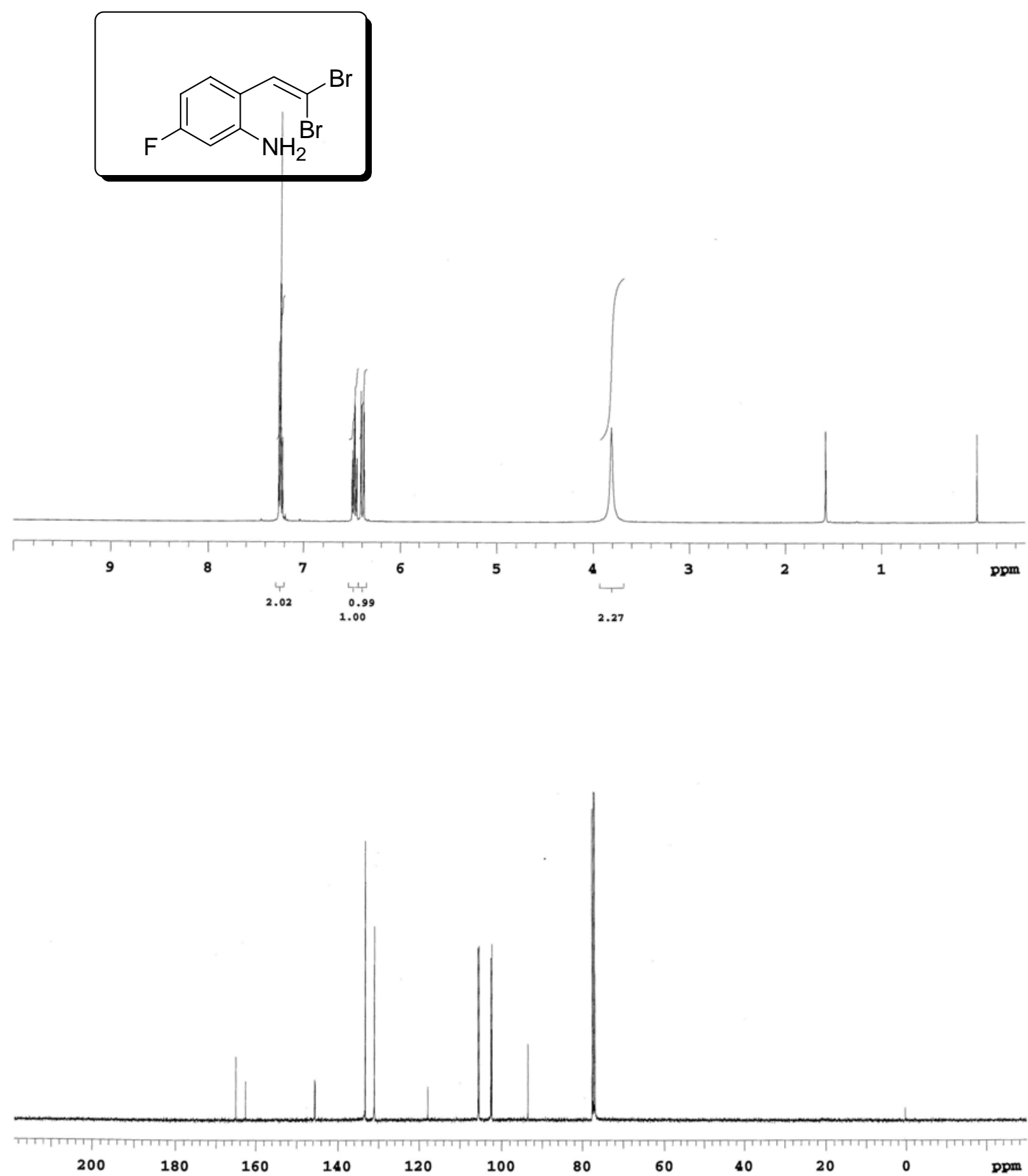
$1 k$
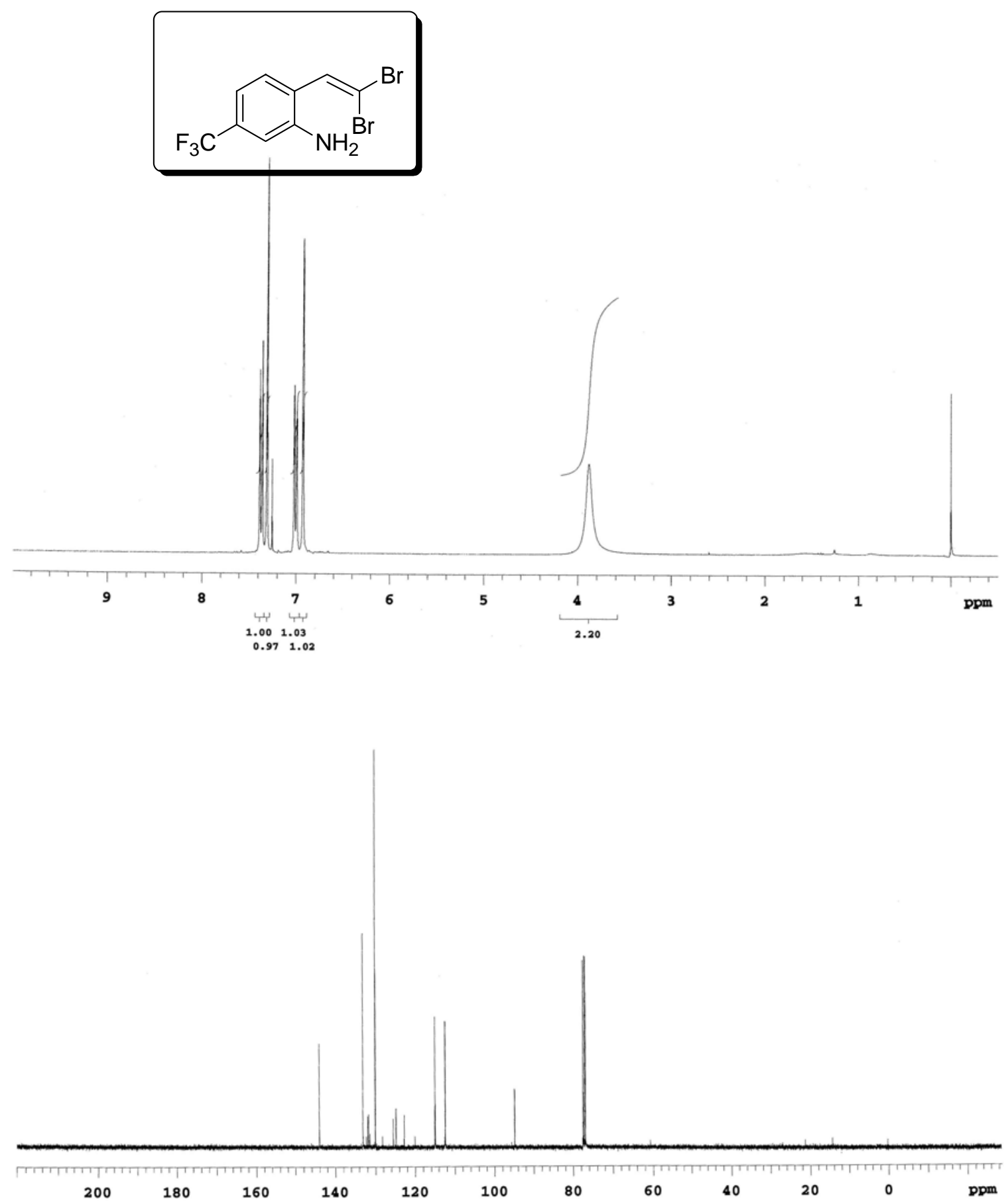
11
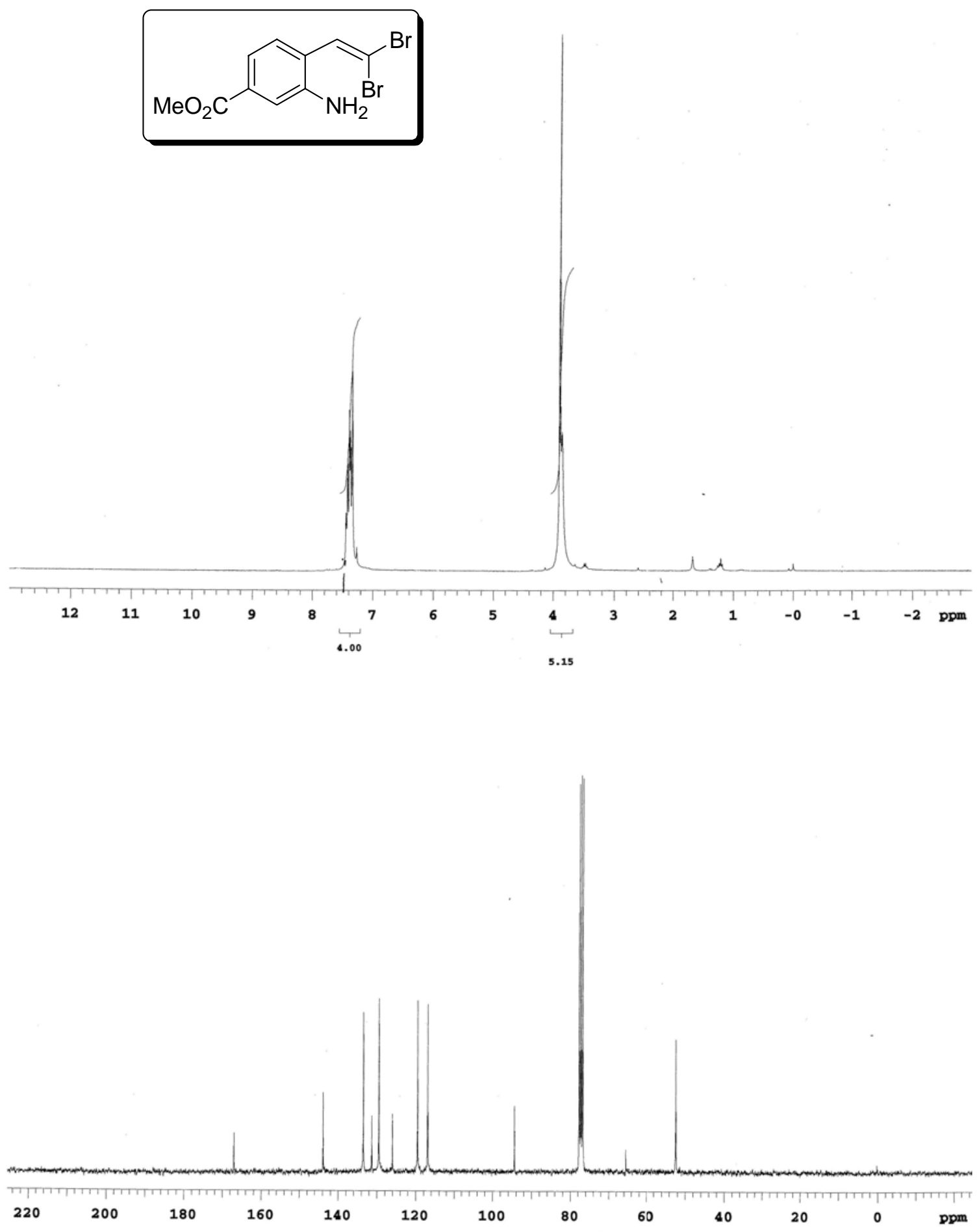

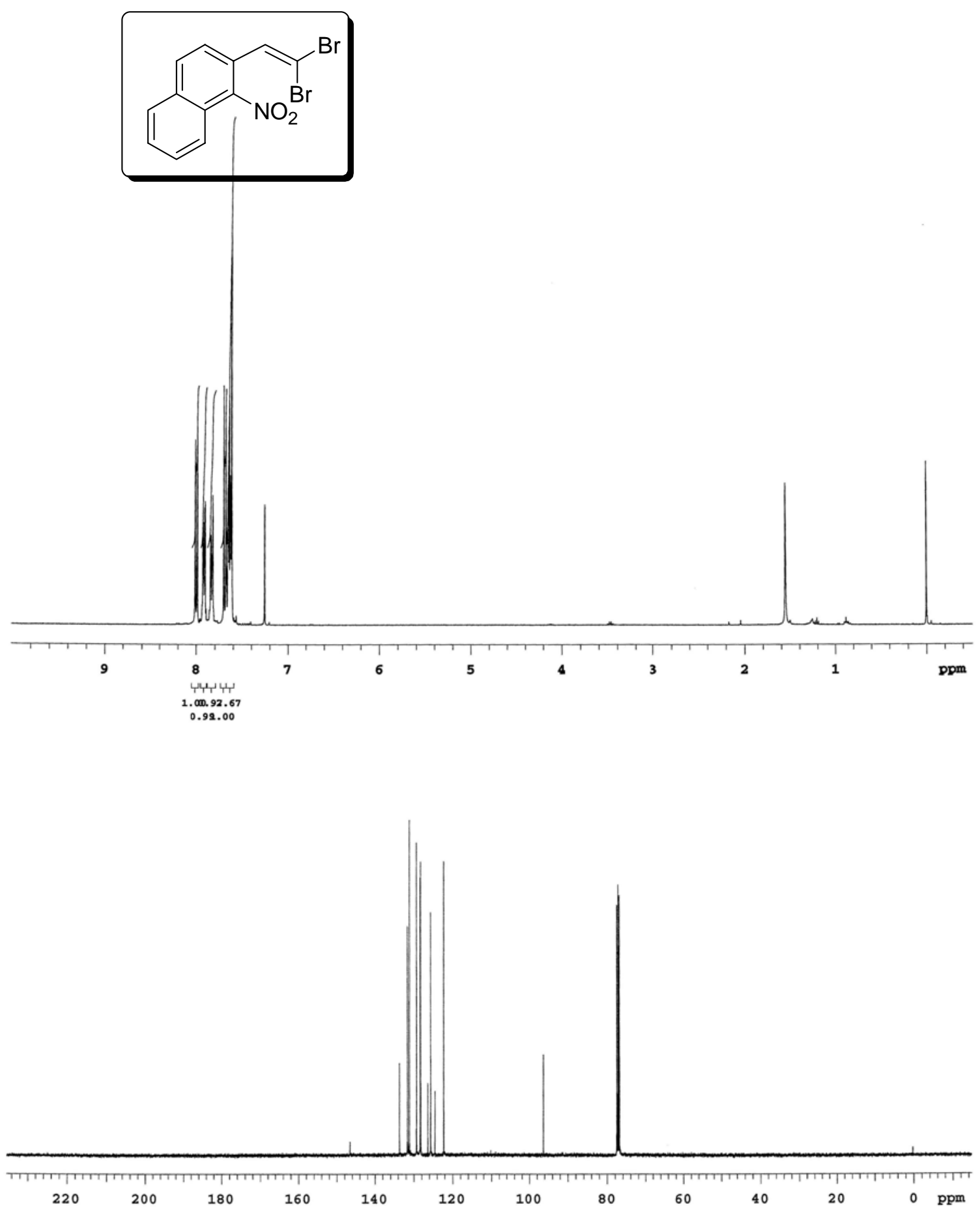
1n
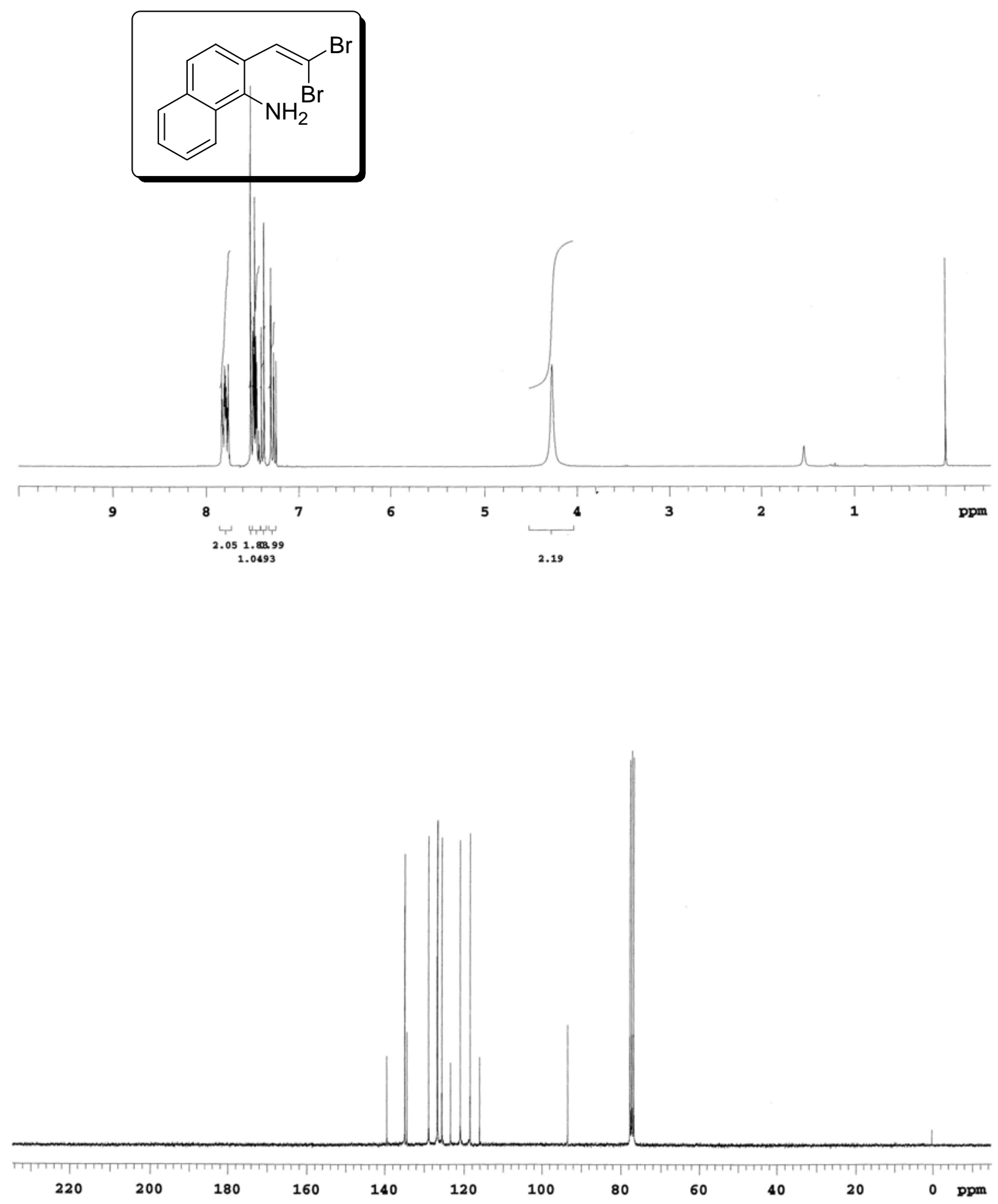

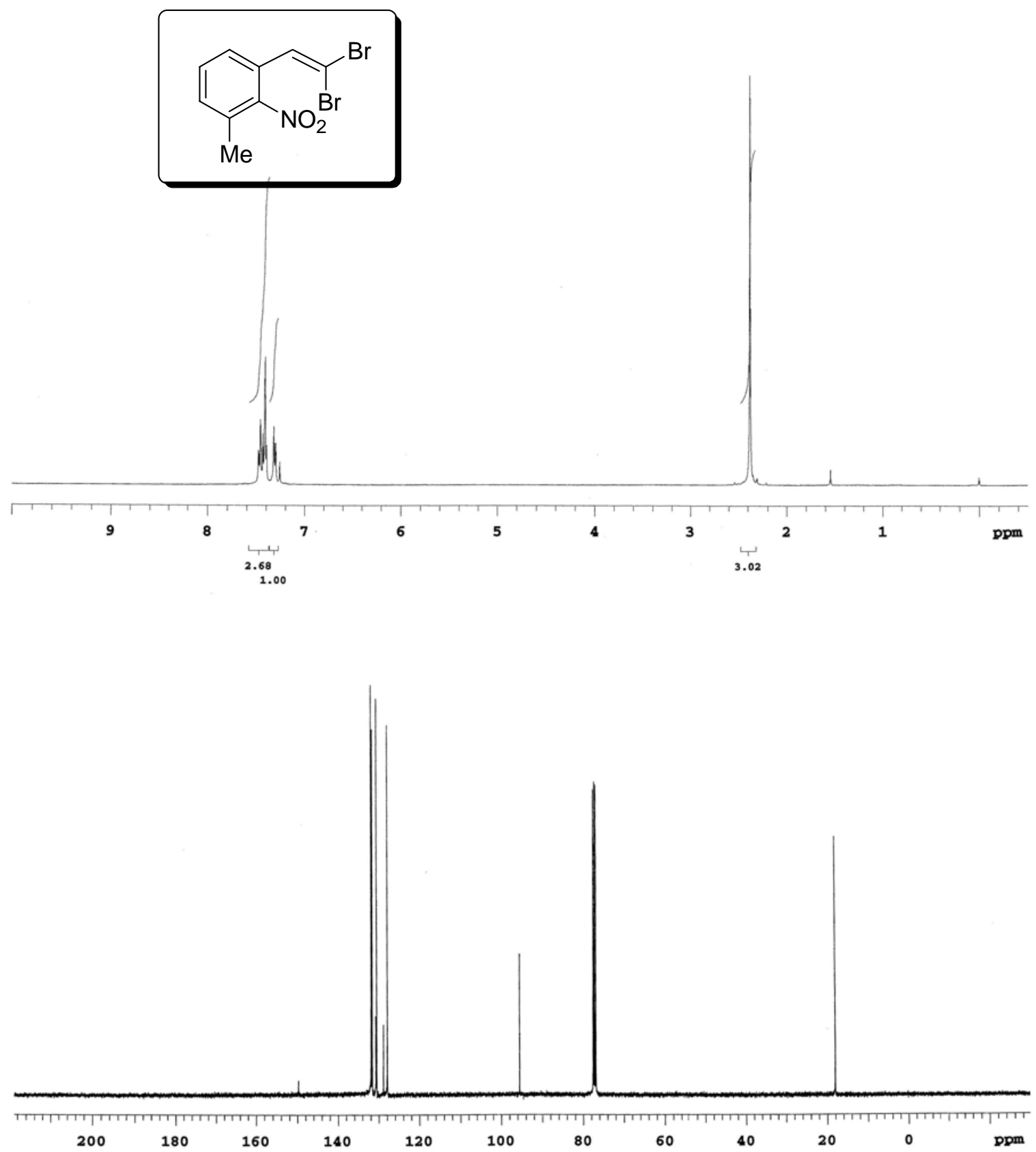
$1 \mathrm{~m}$
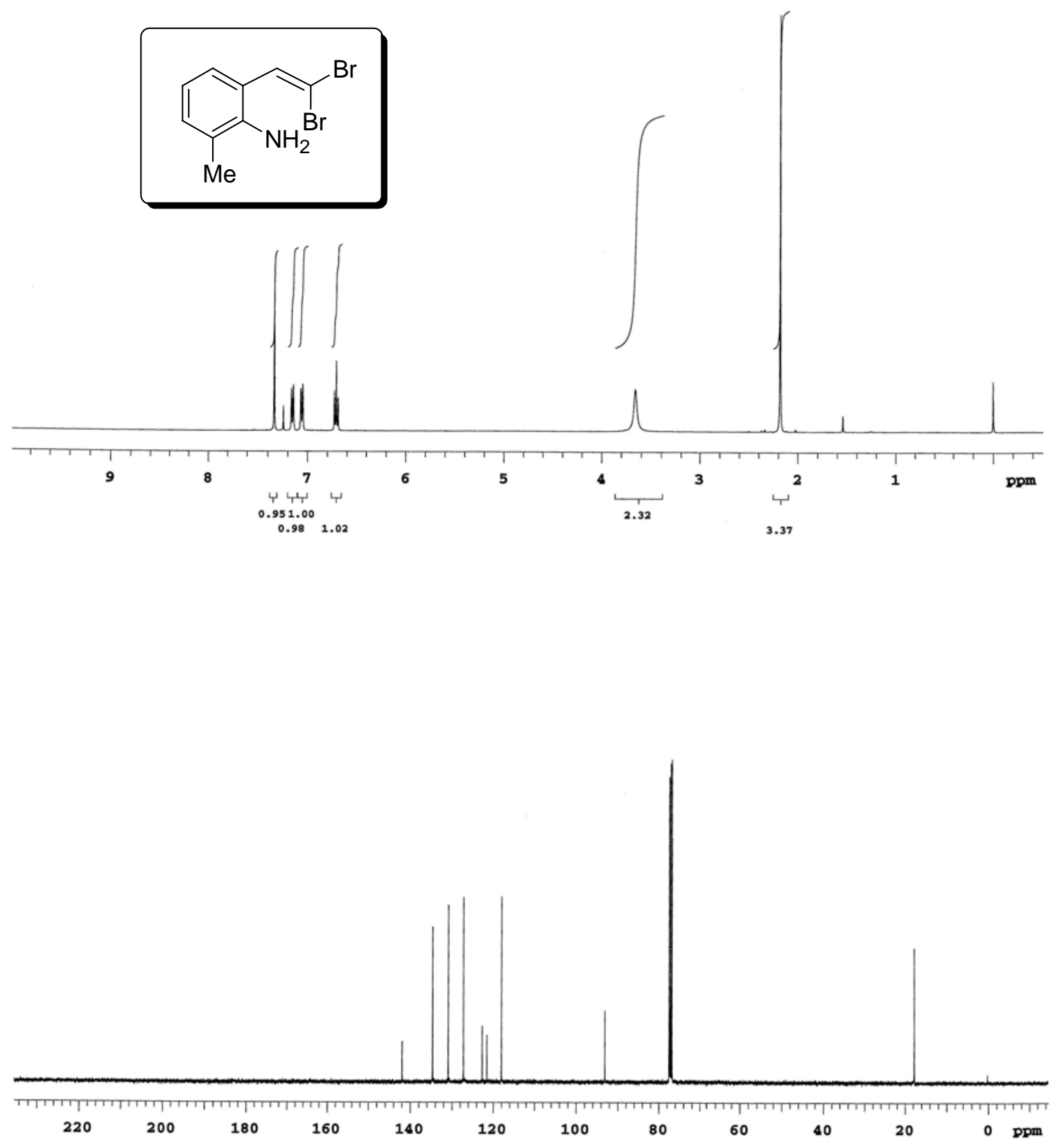
17j
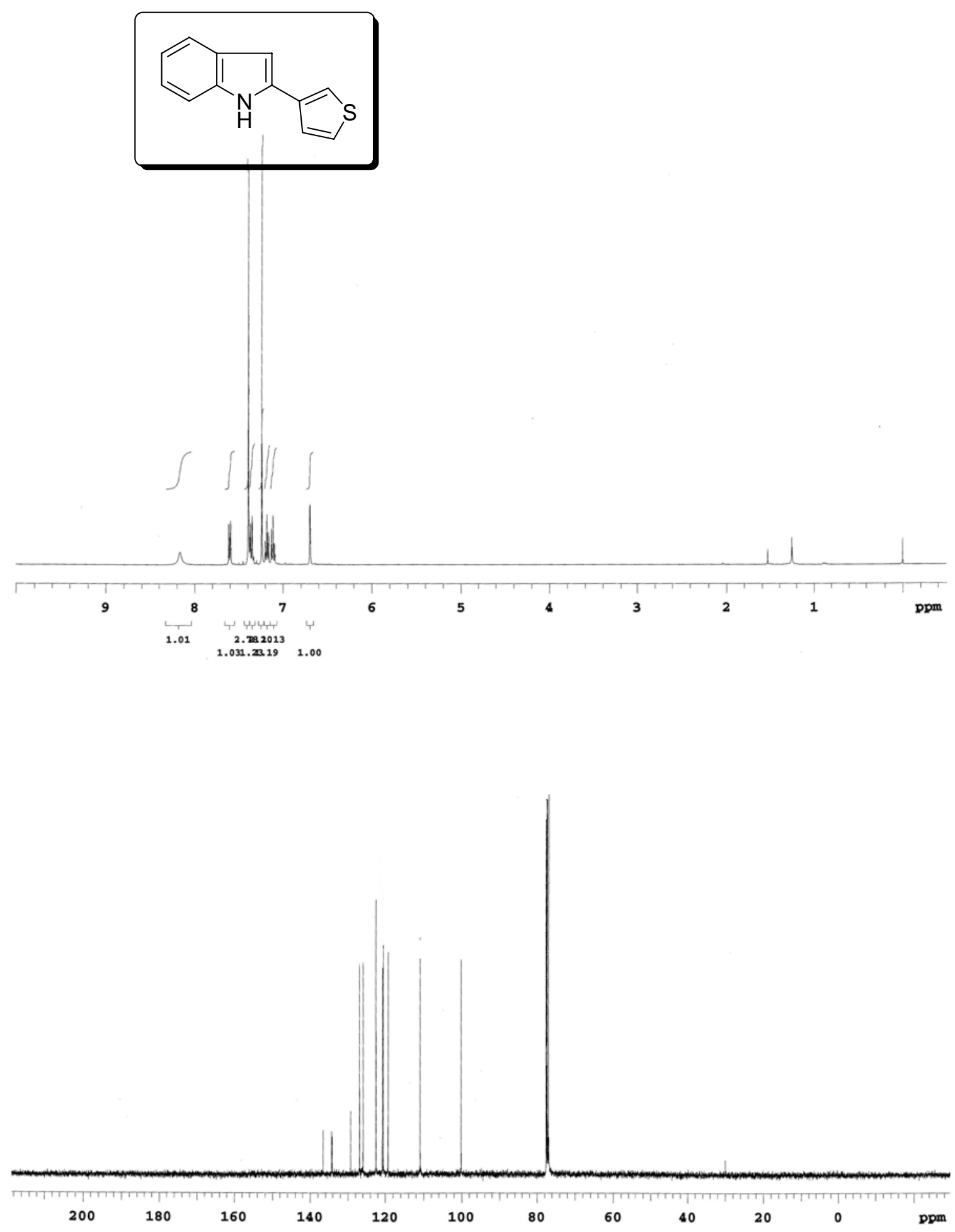
17k
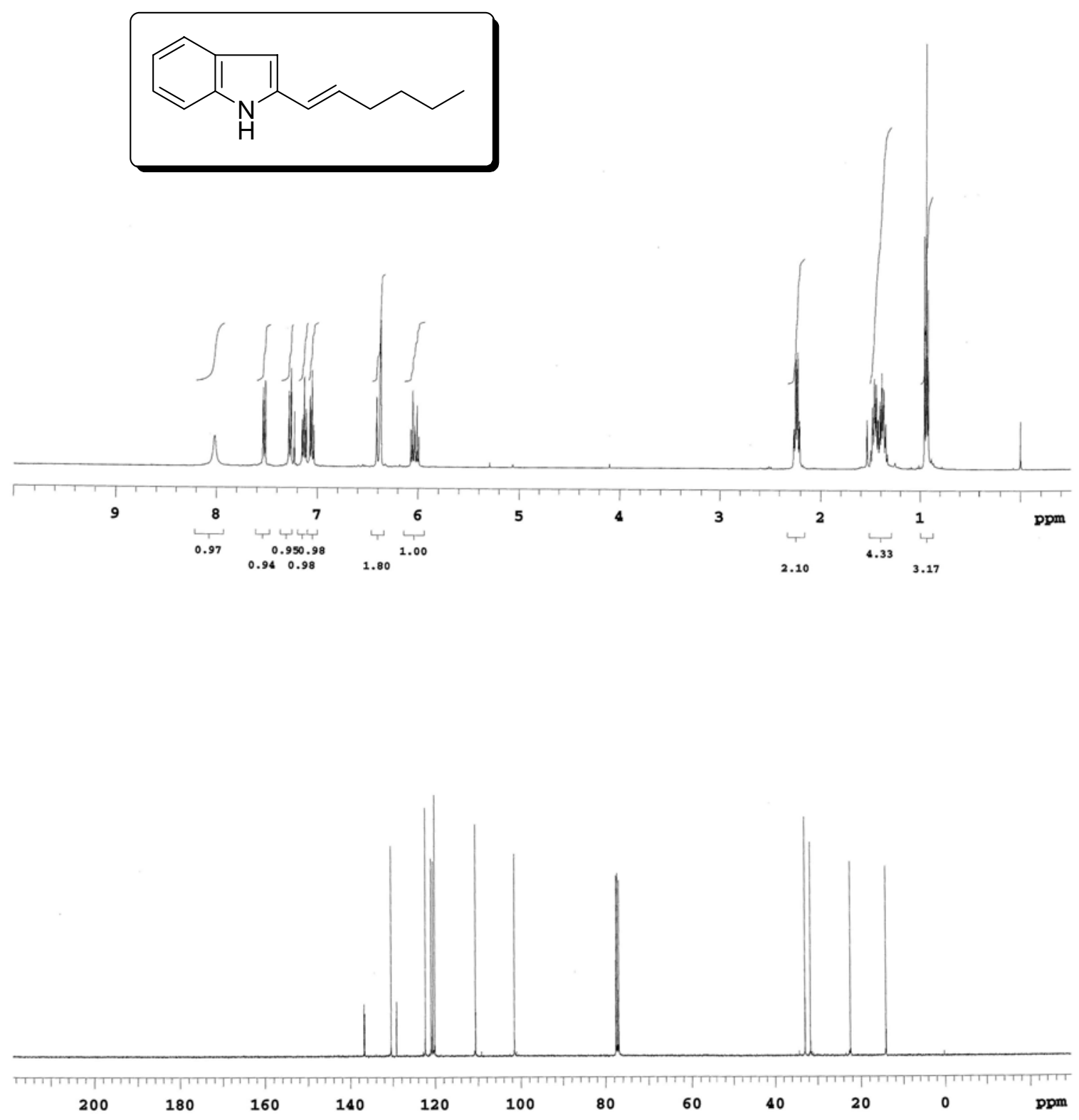
17p
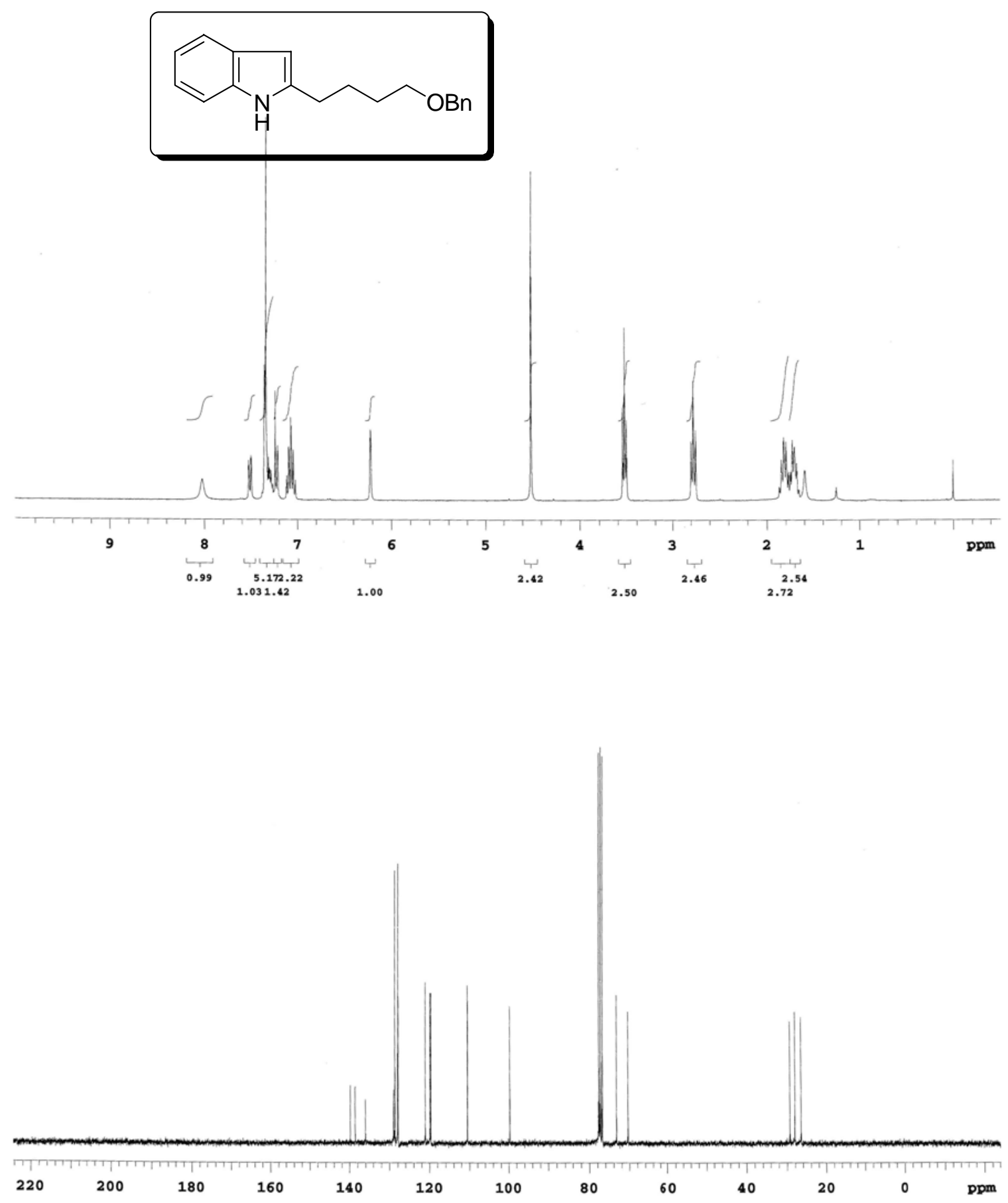
18b
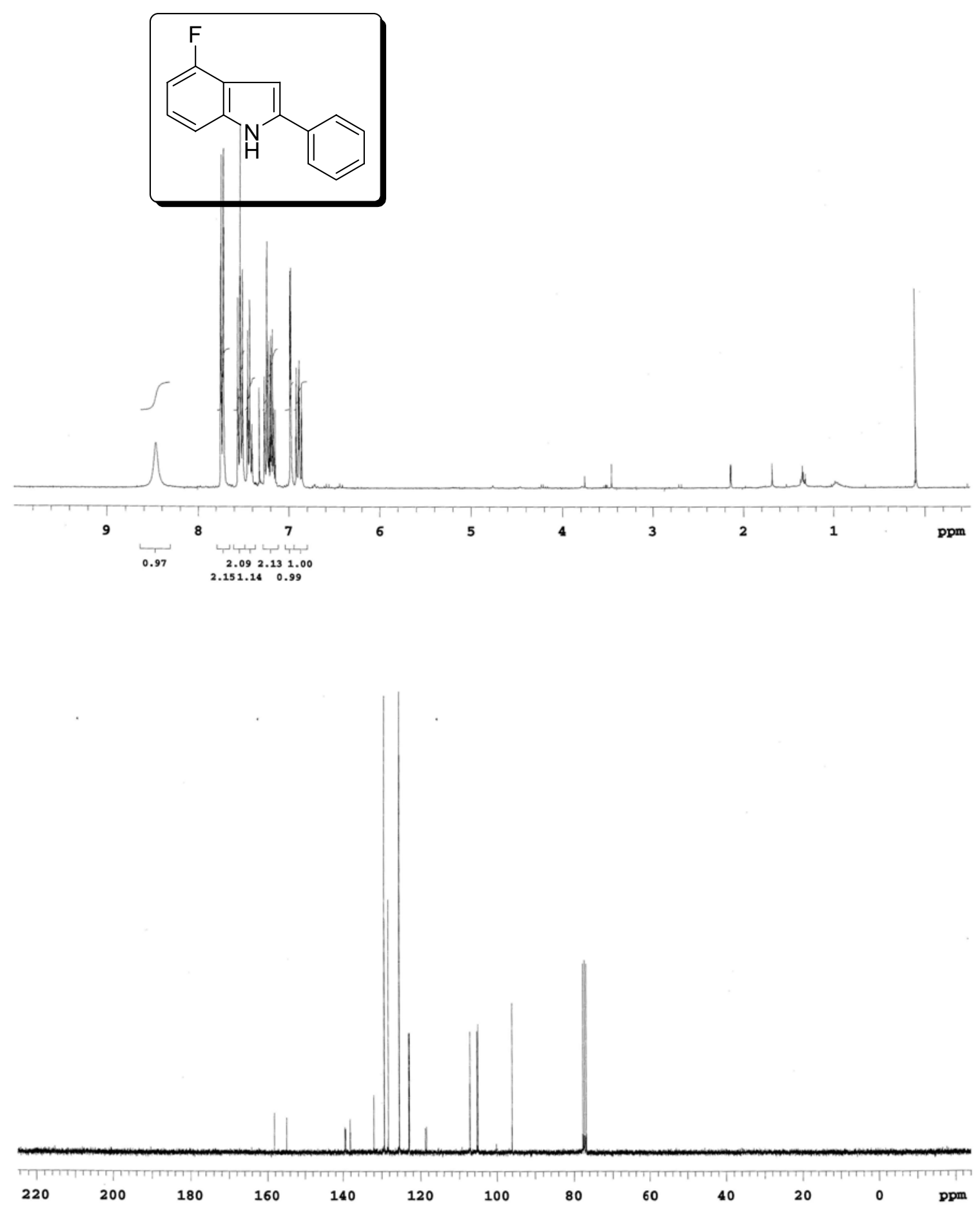

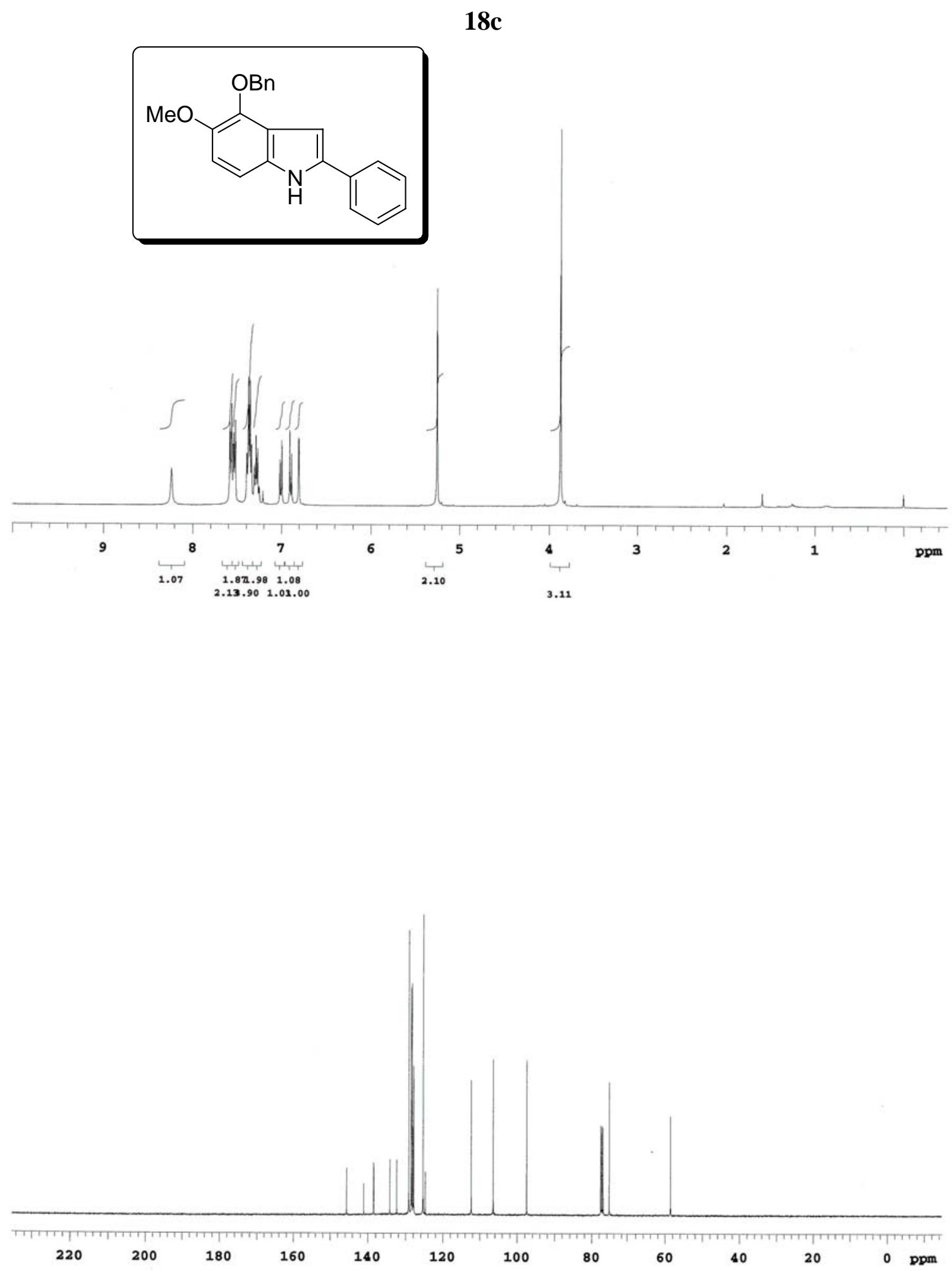
18d
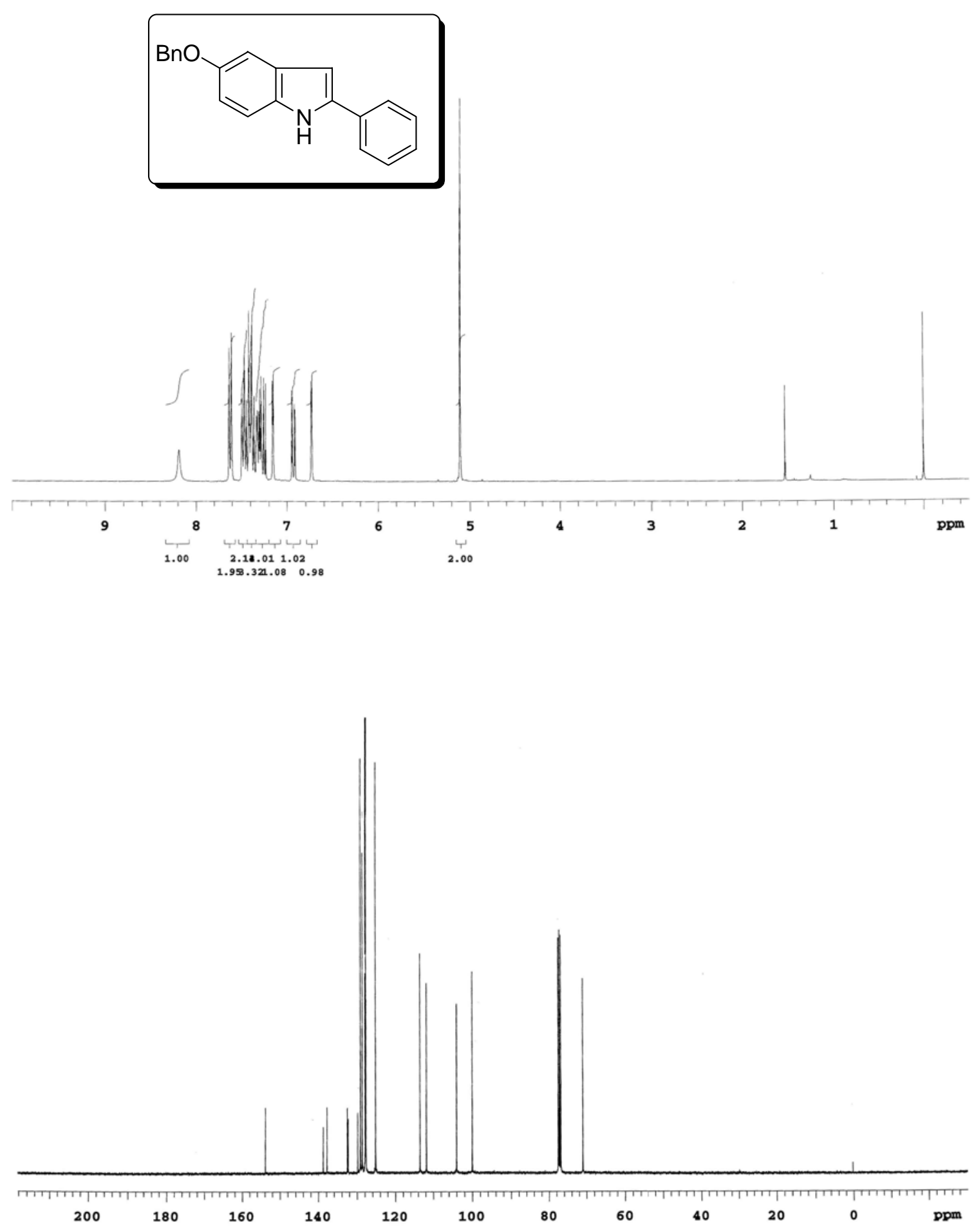
18g
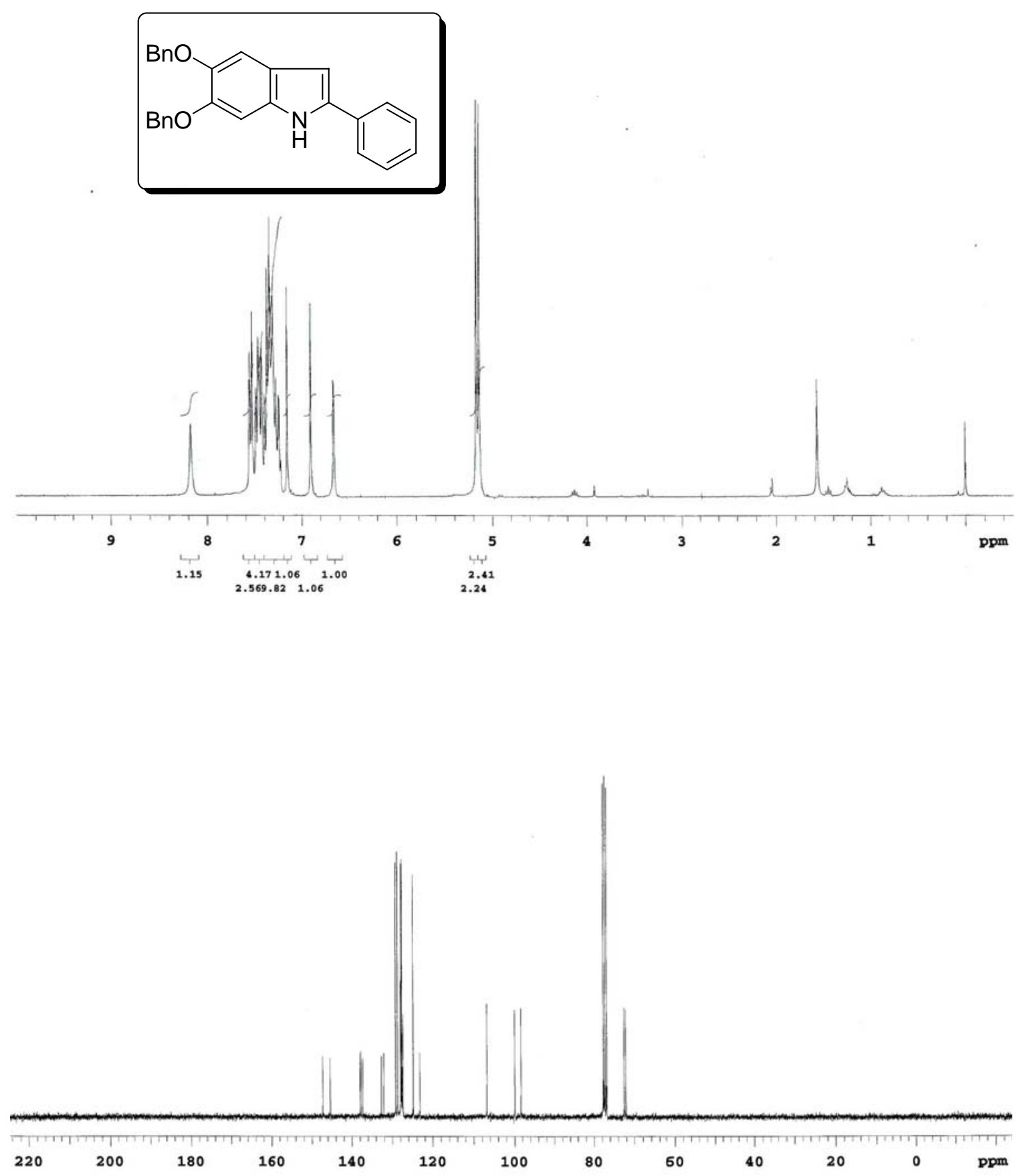
18h
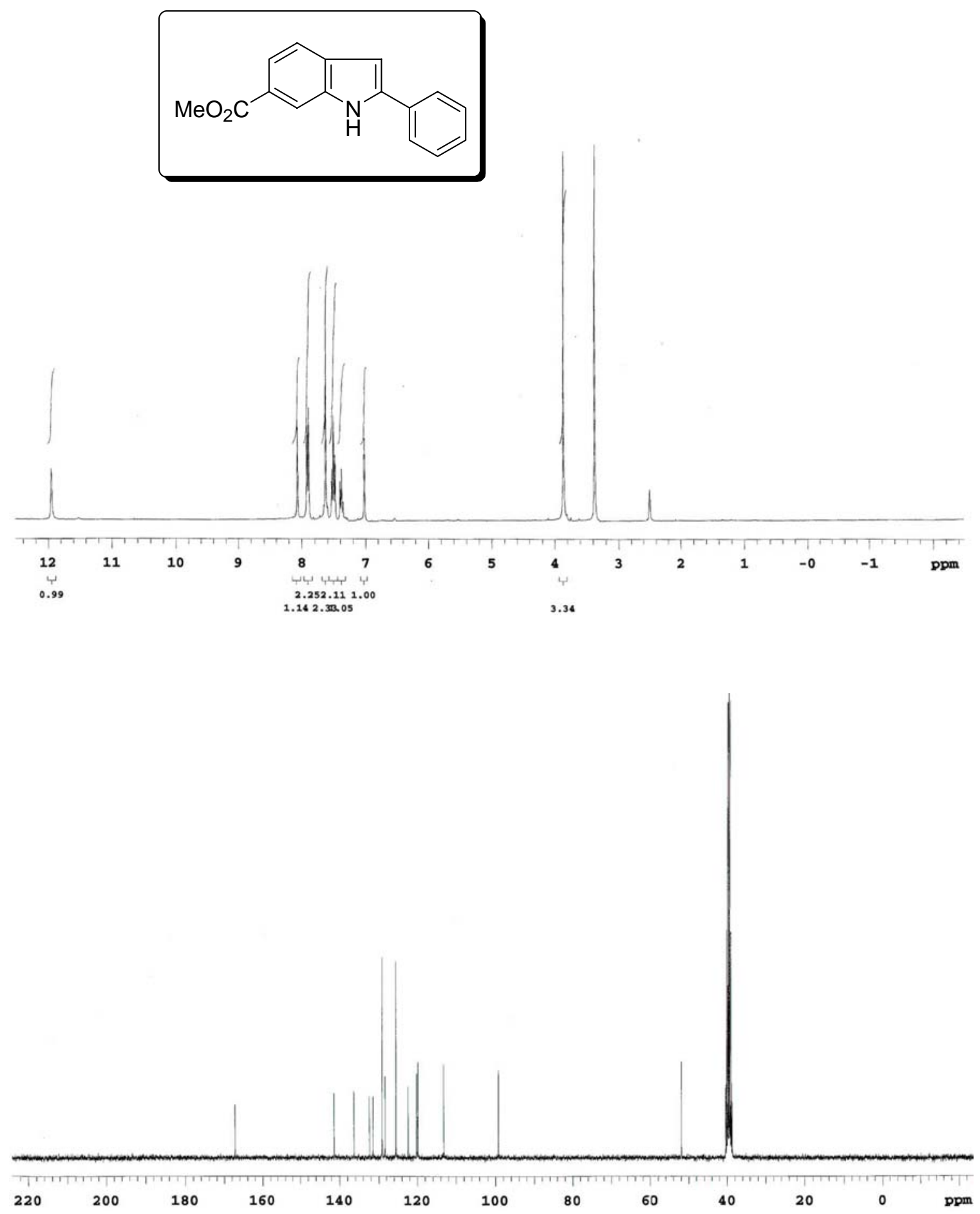
19c
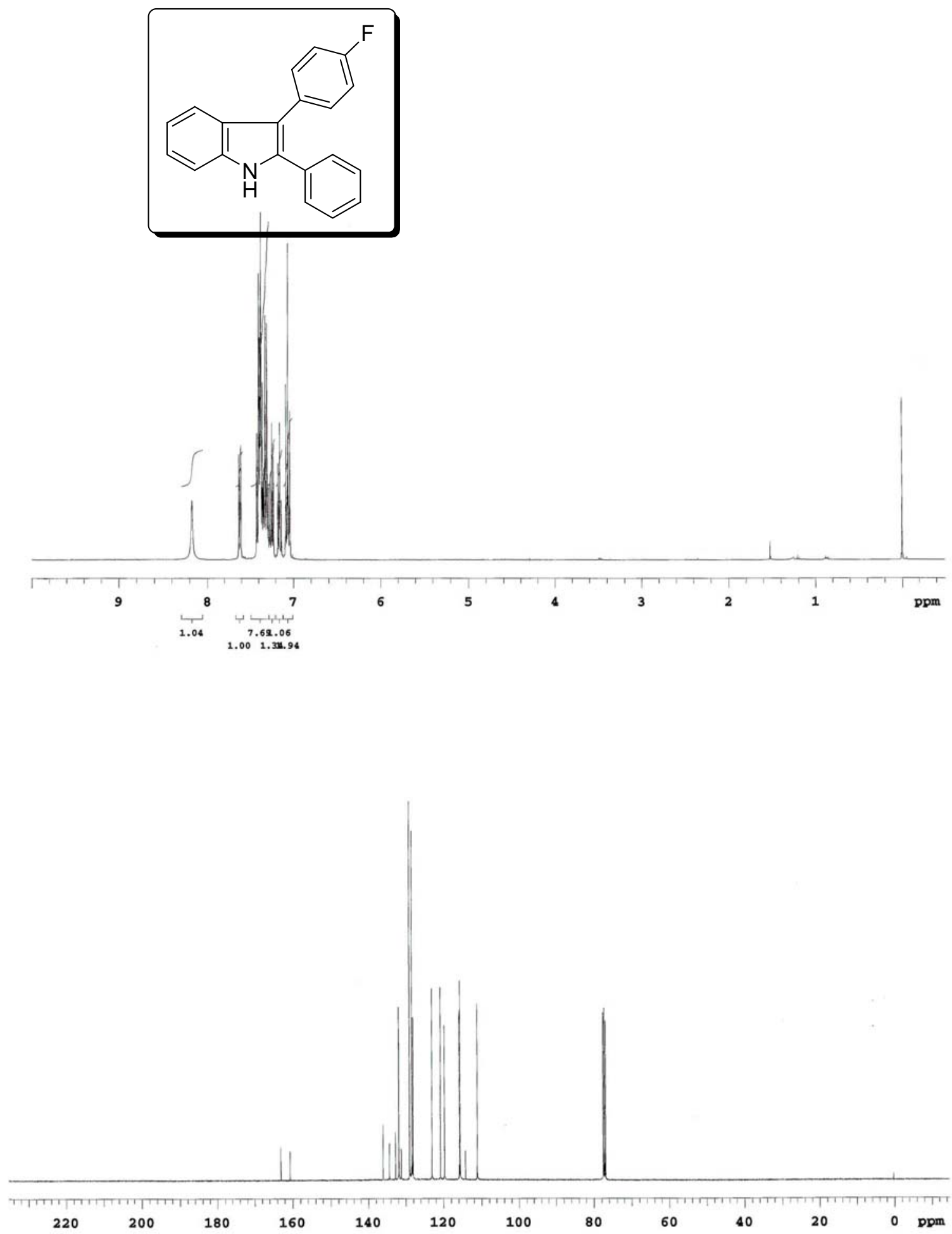
3a
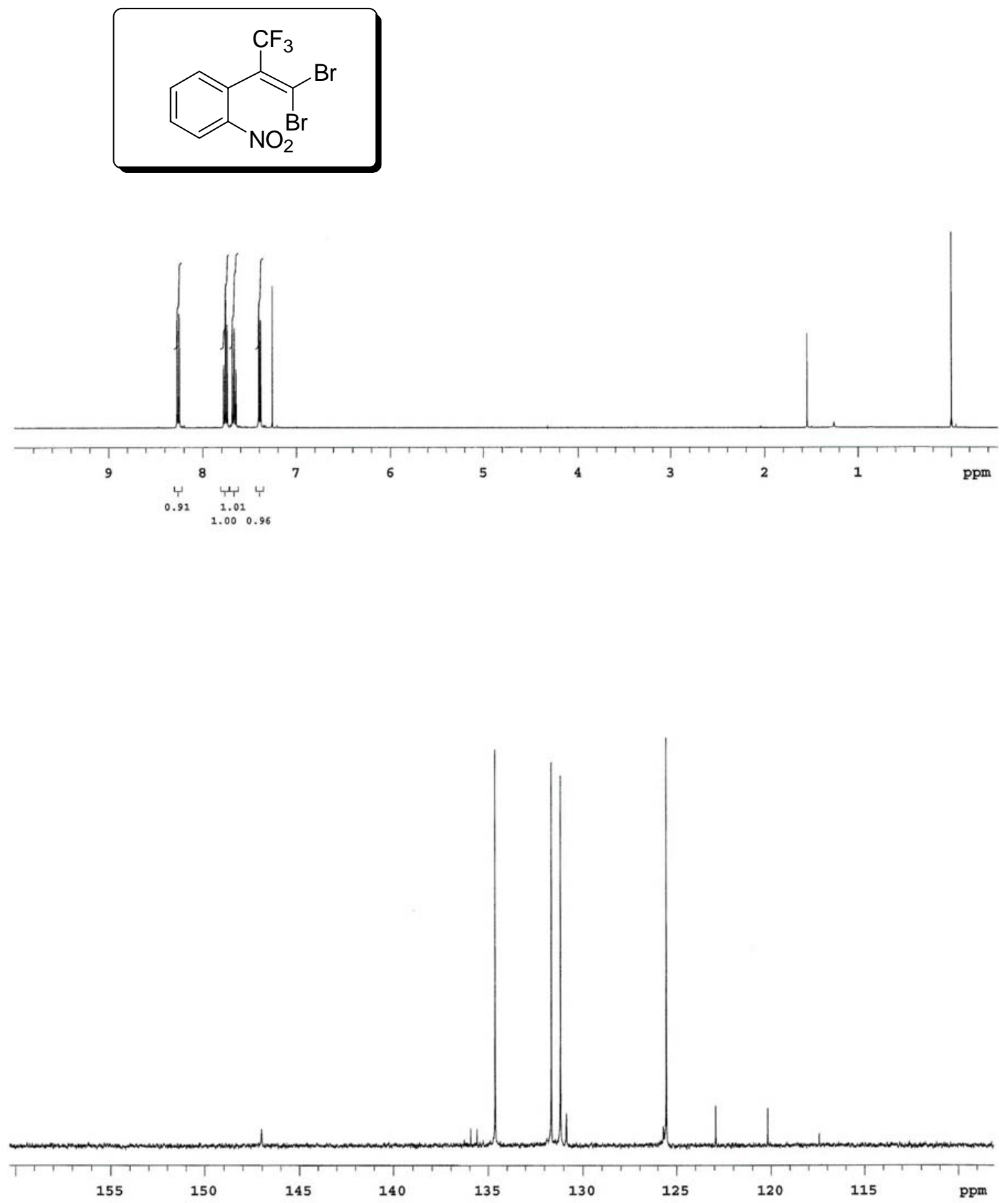

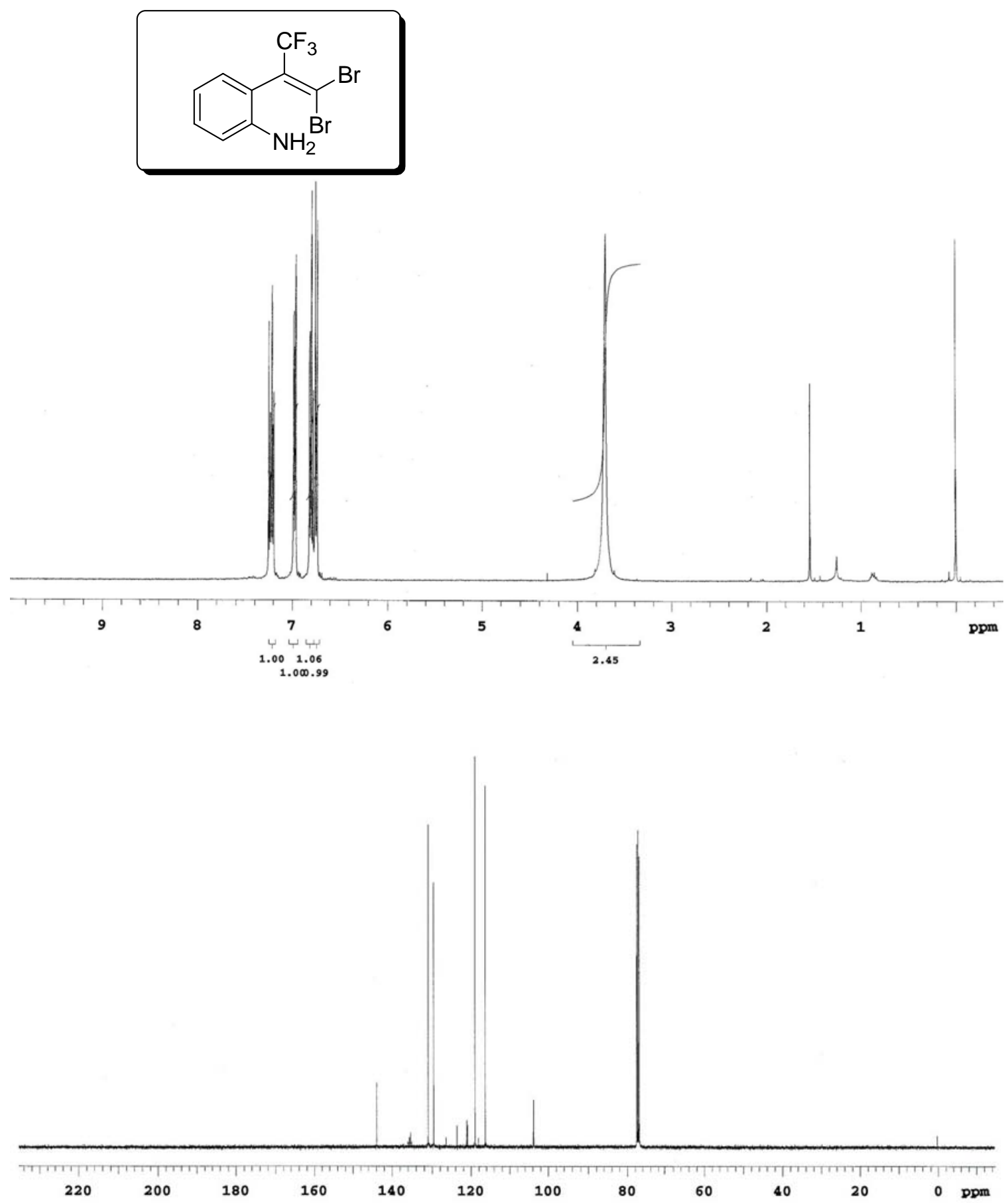

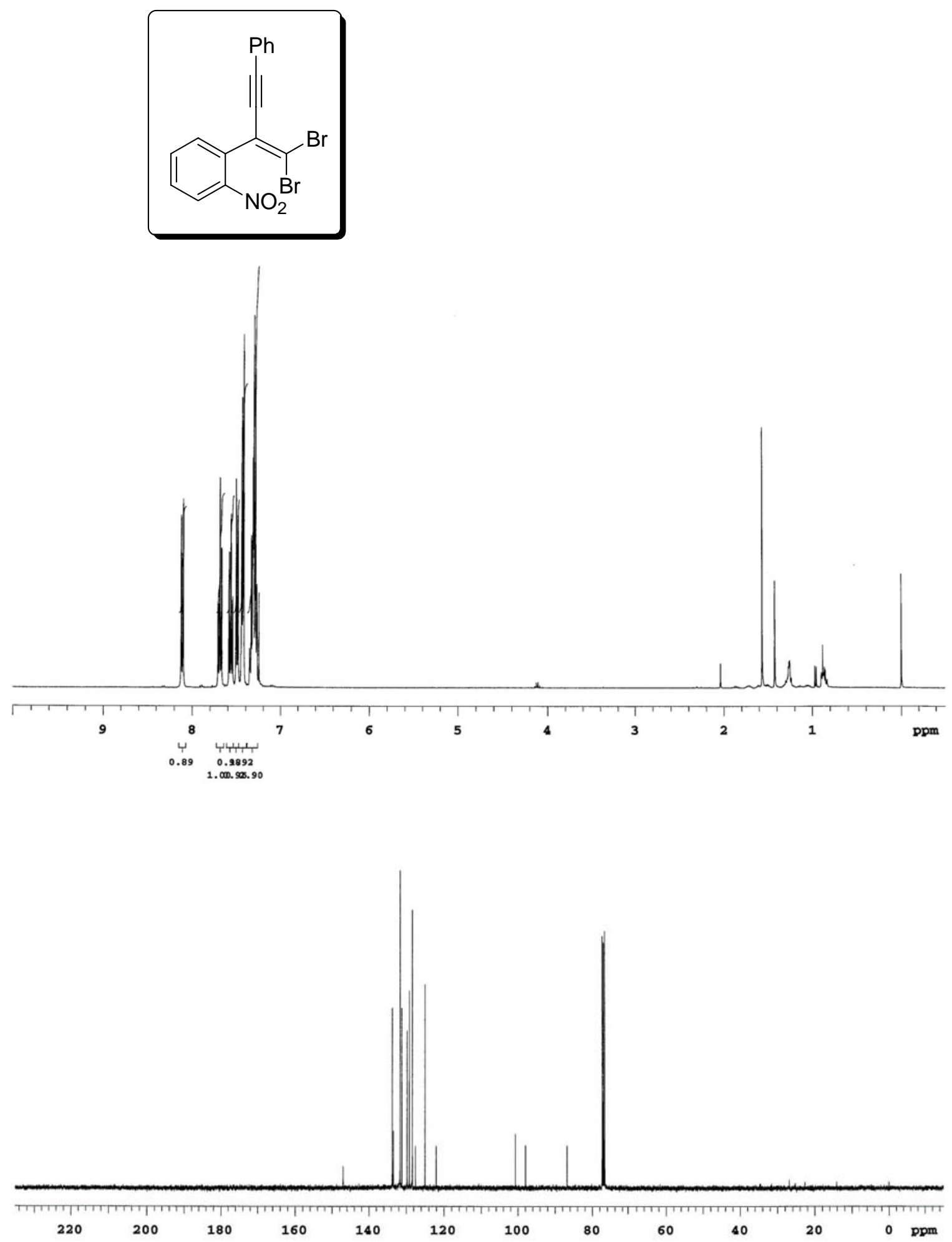

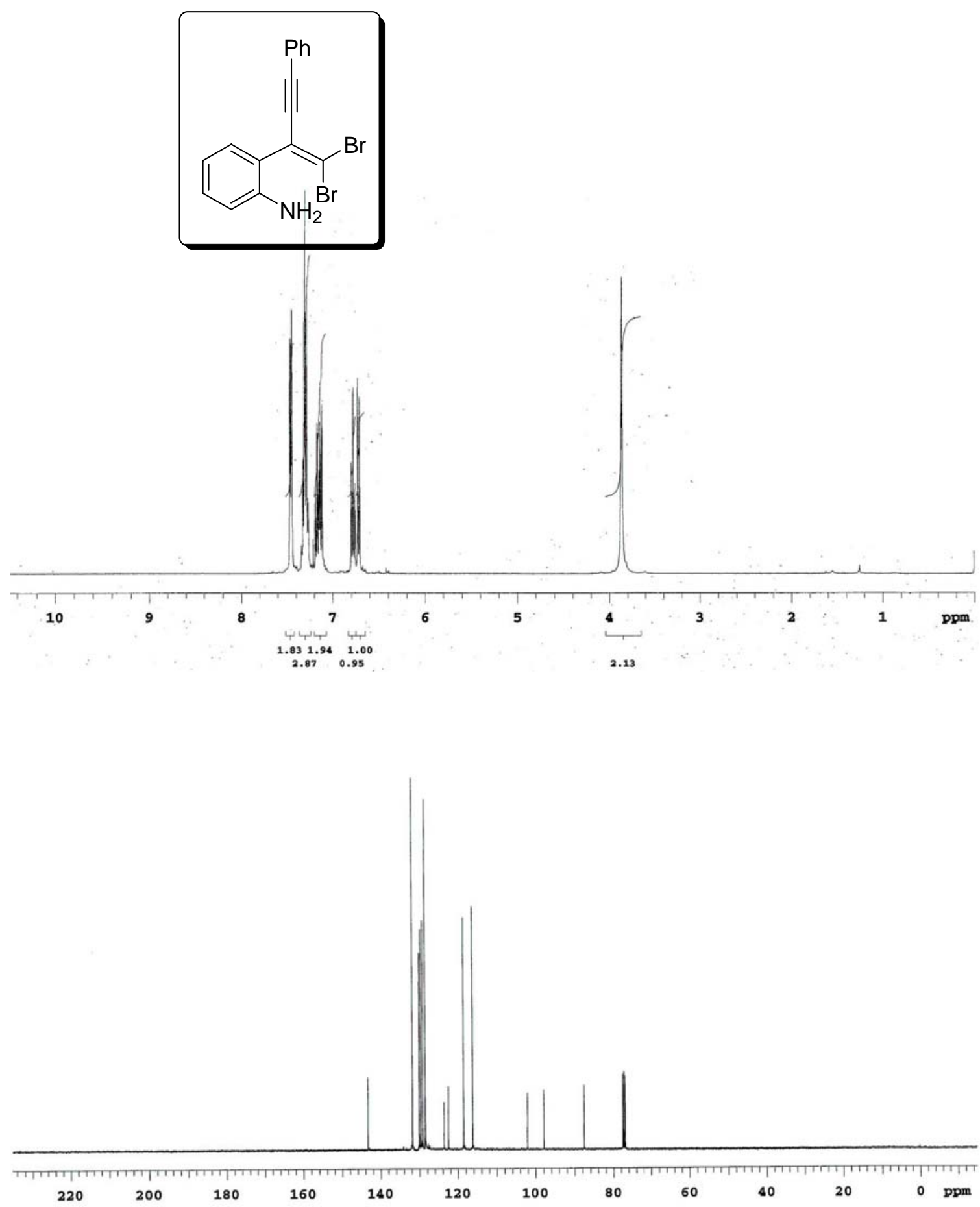

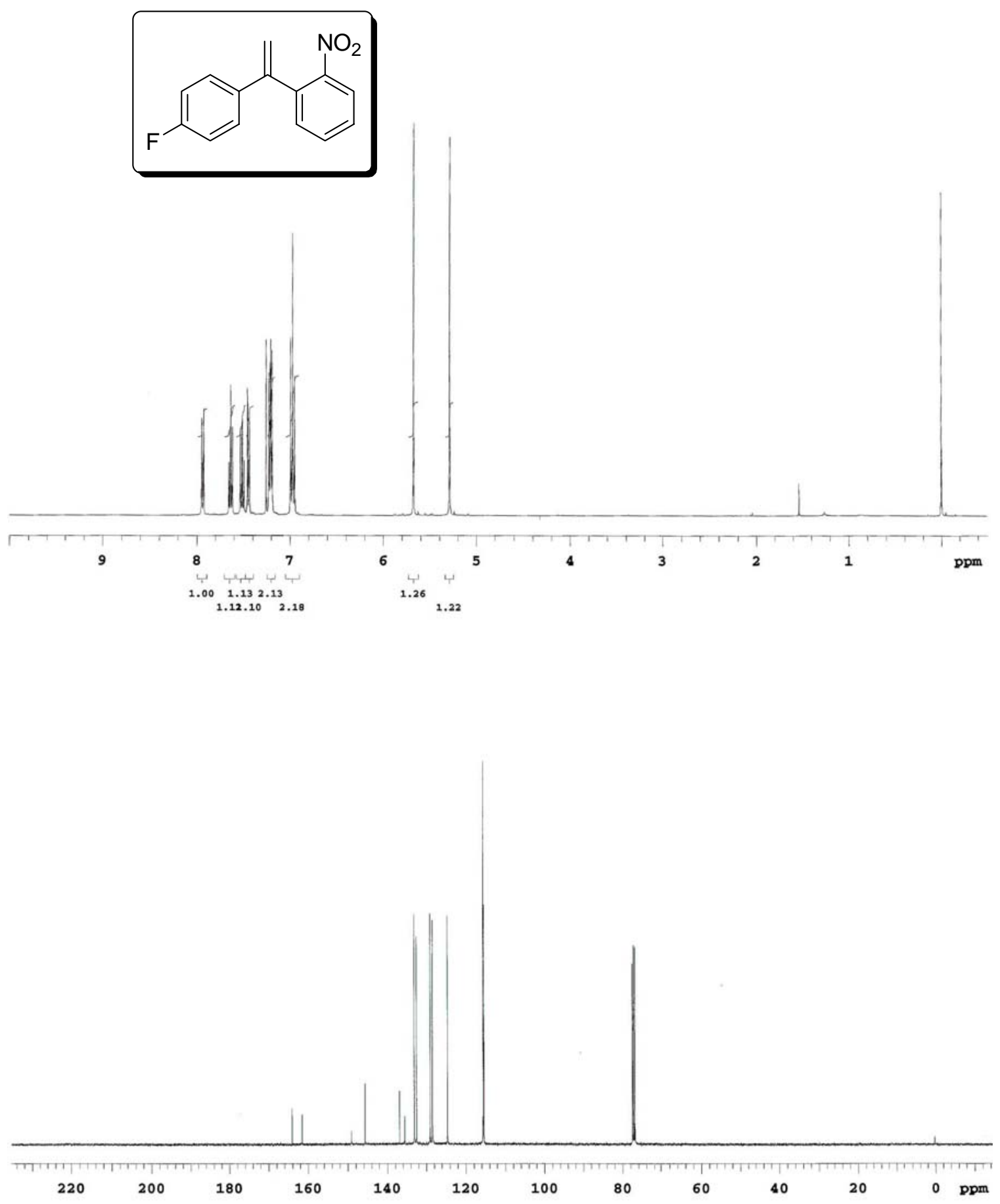

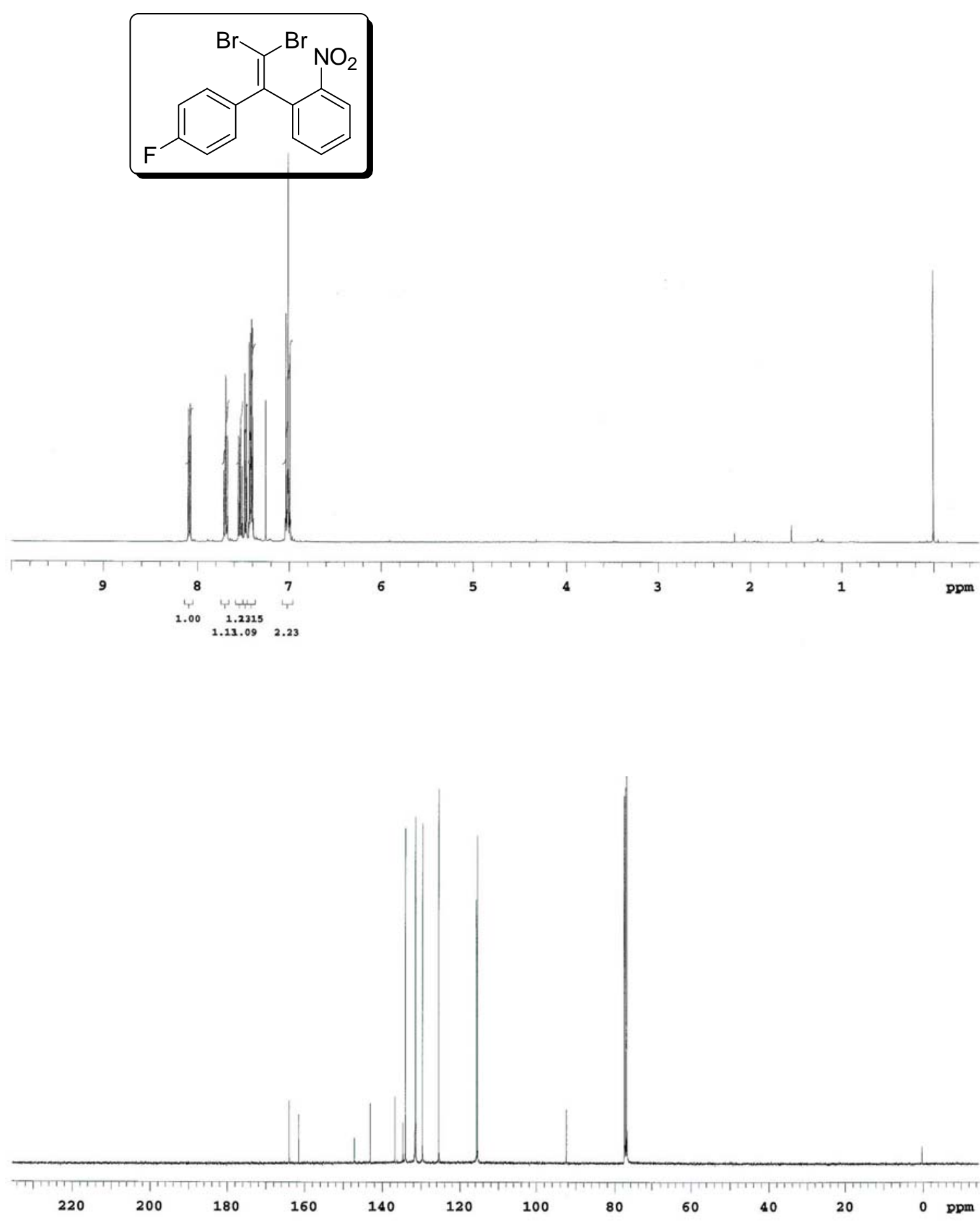

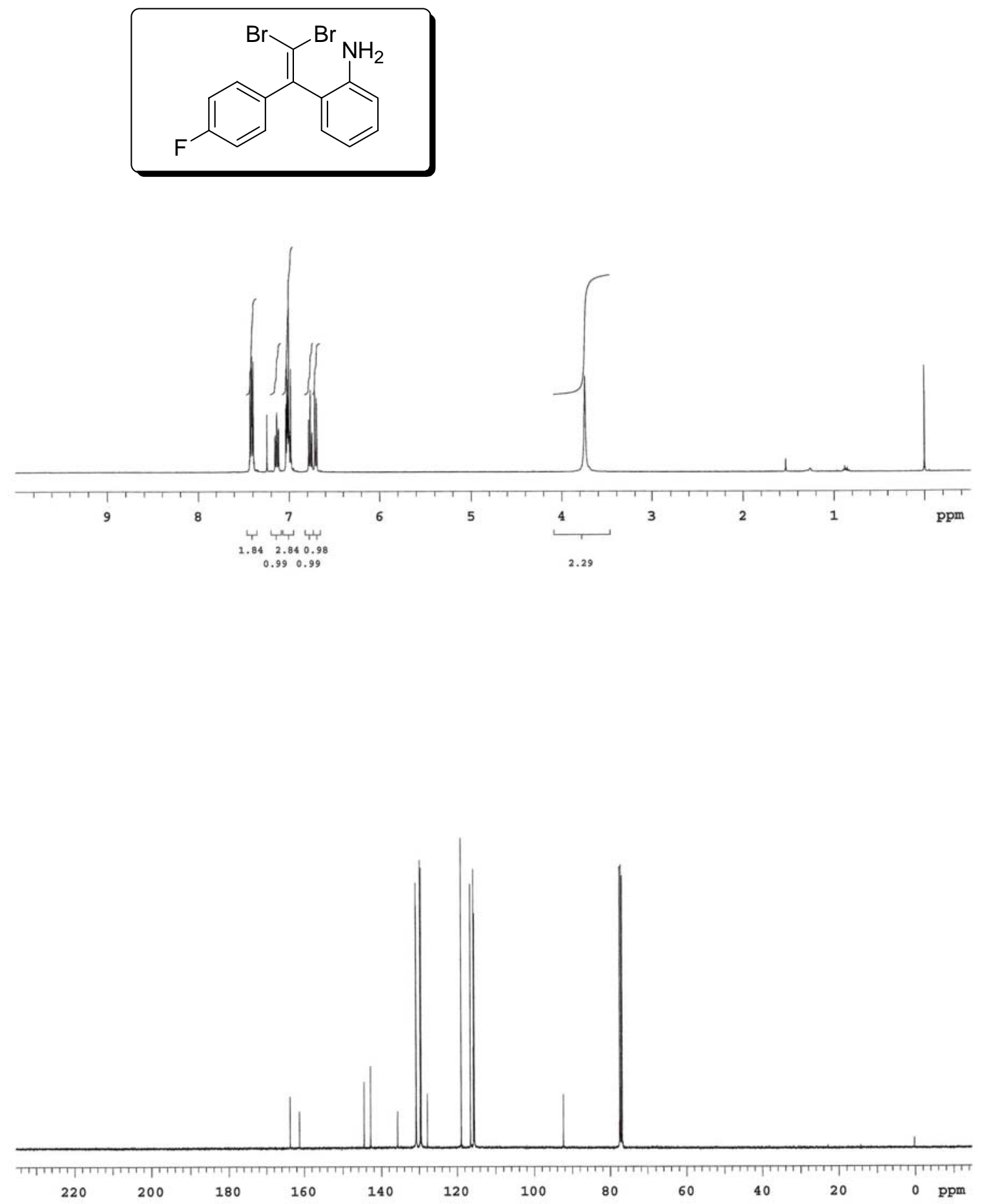

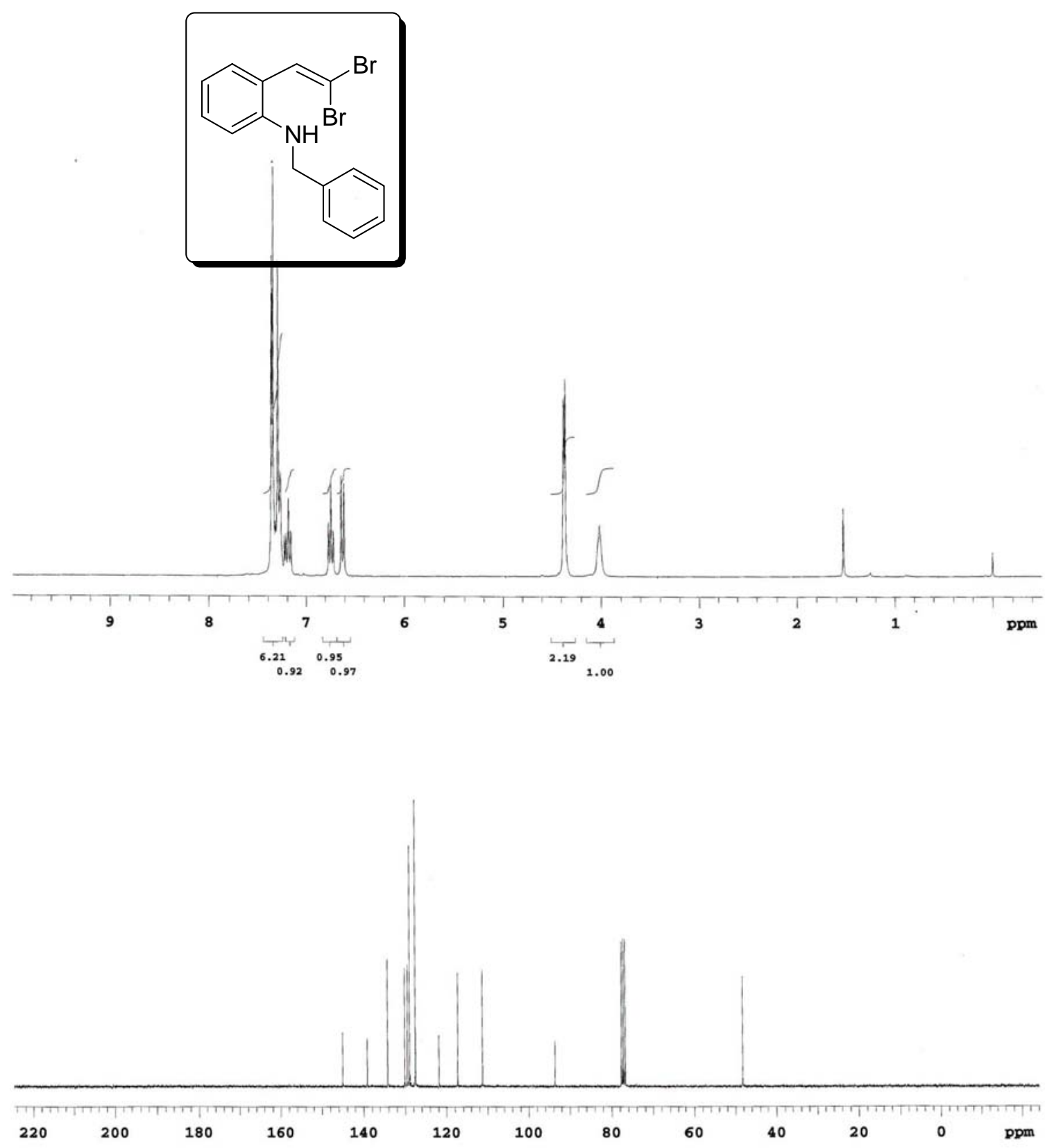

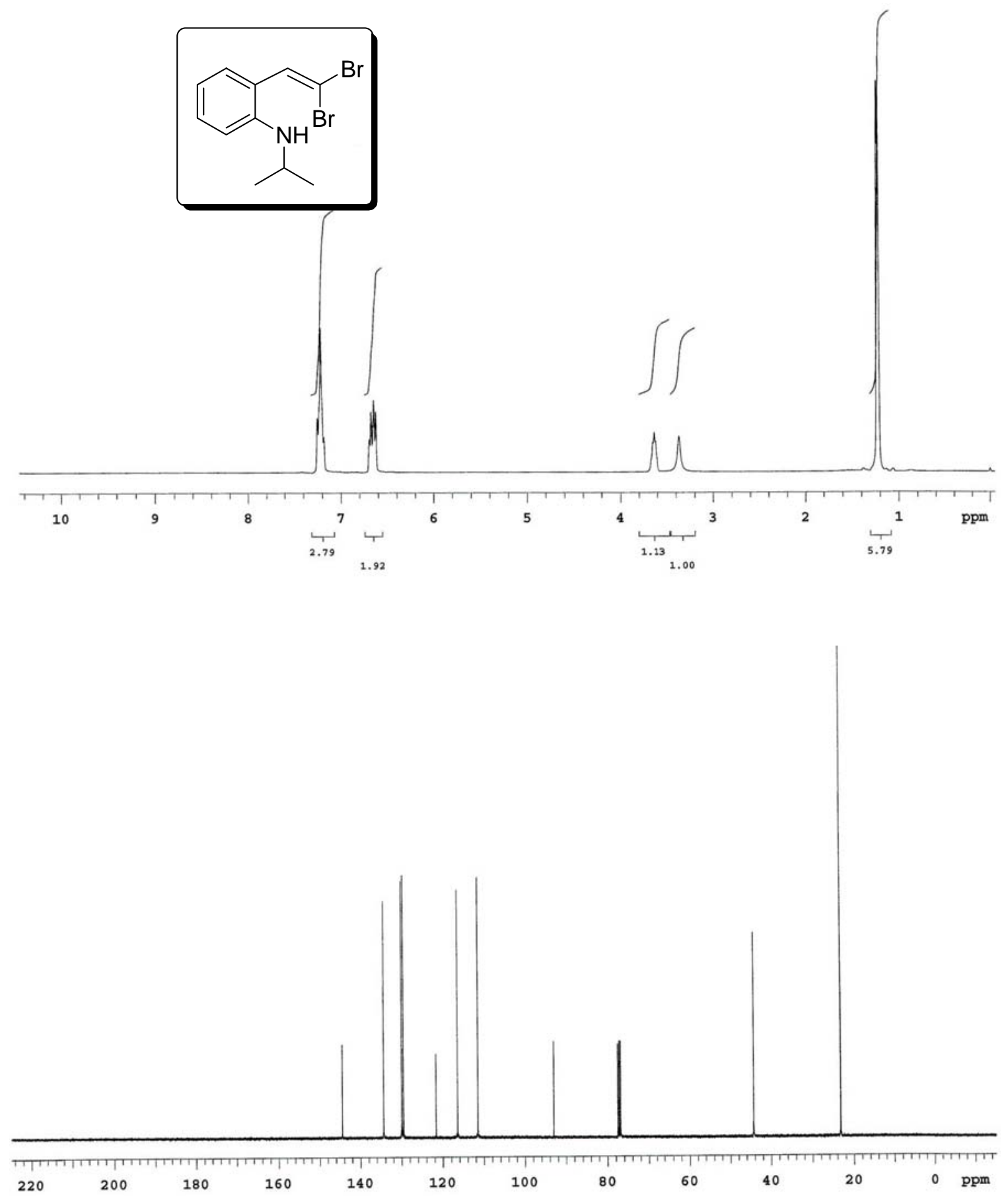

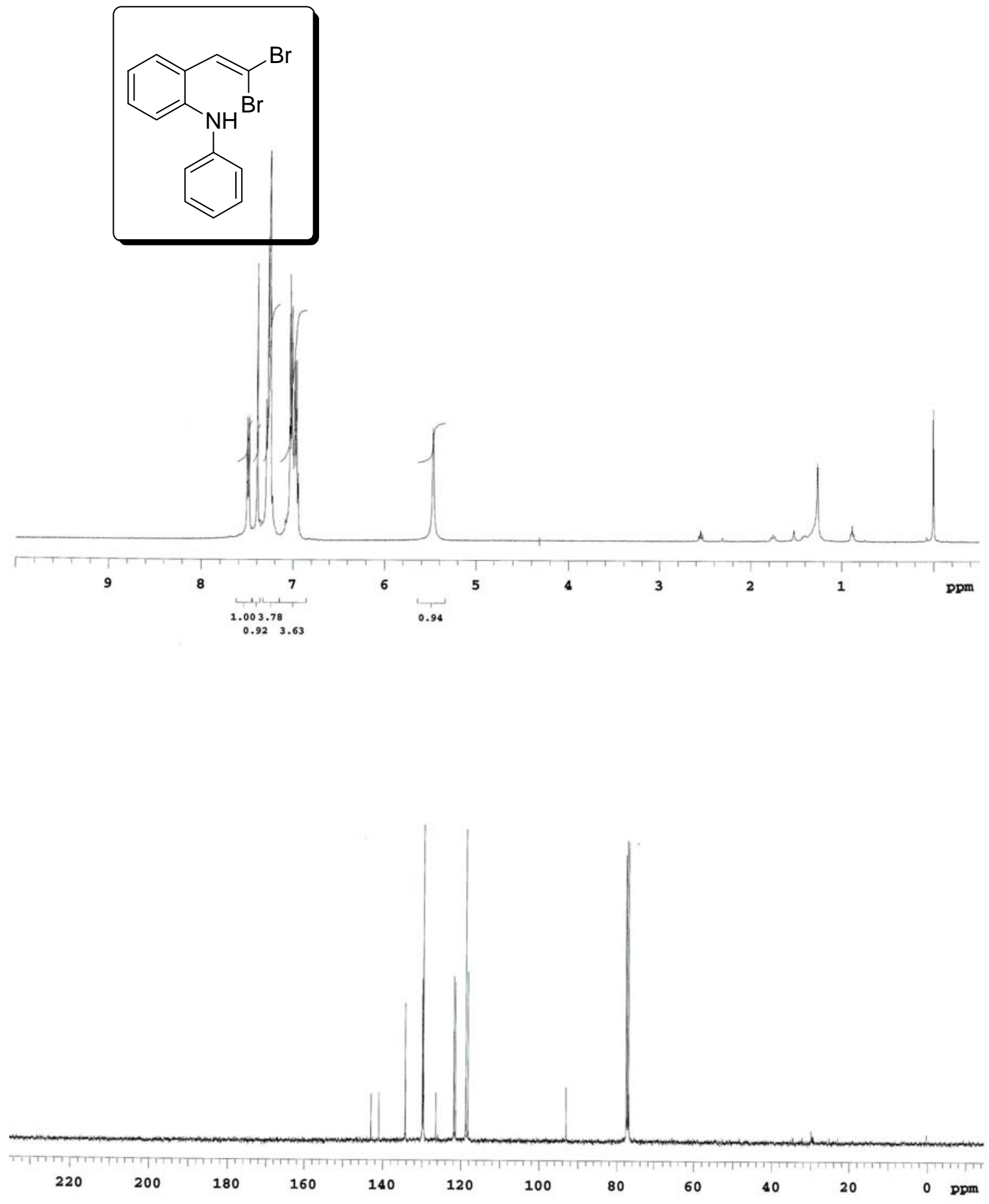
24b
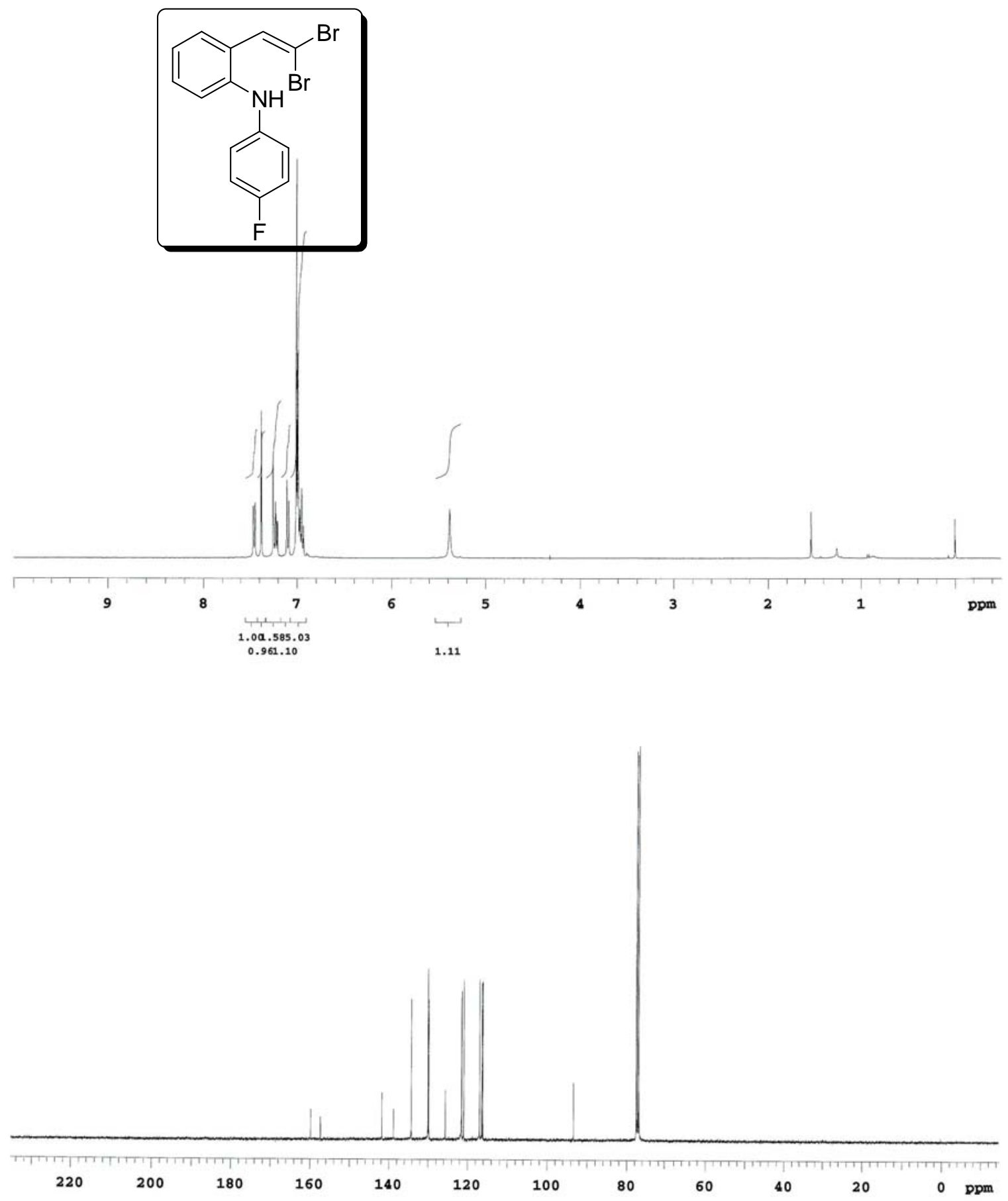
S95

24c
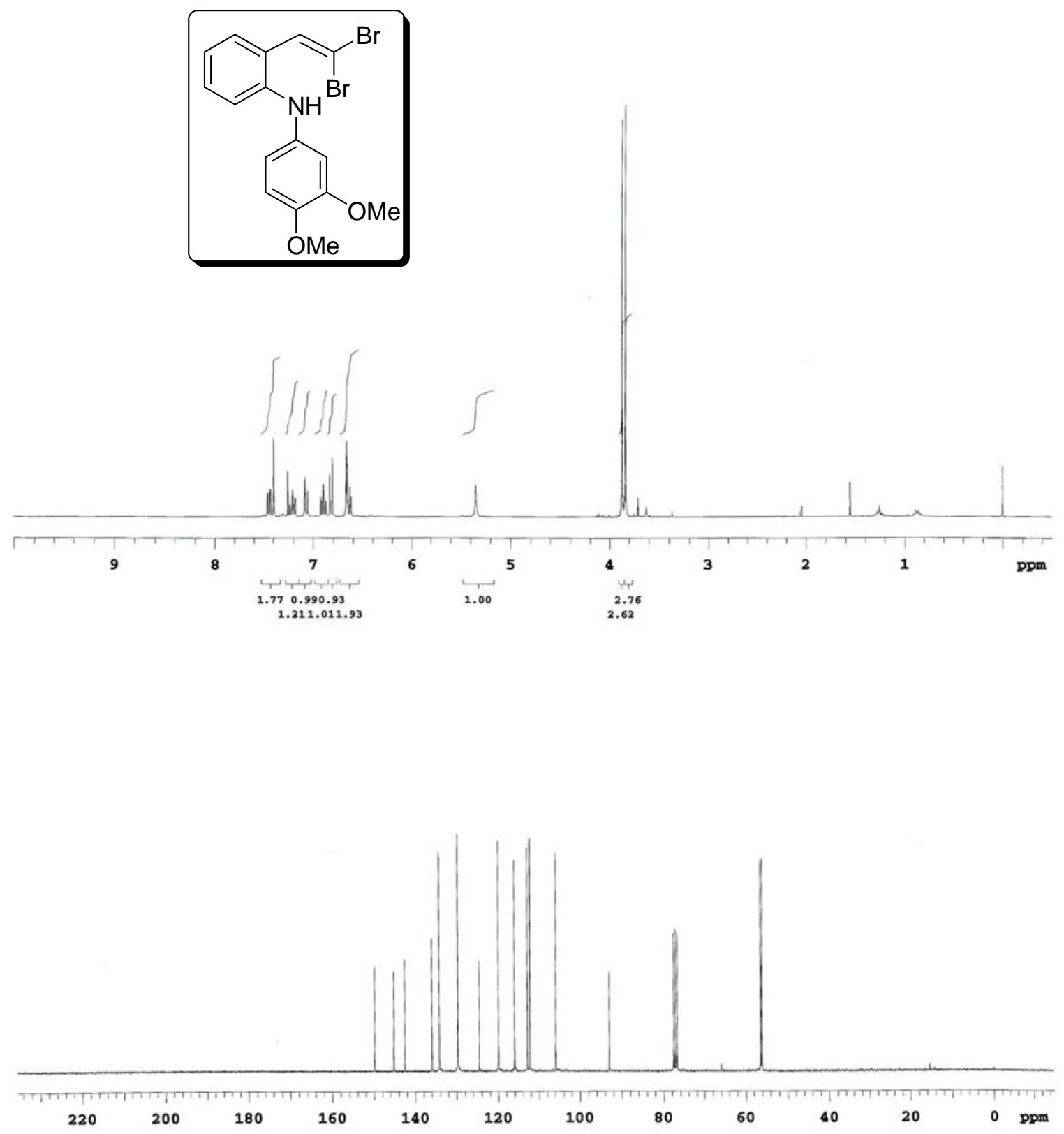

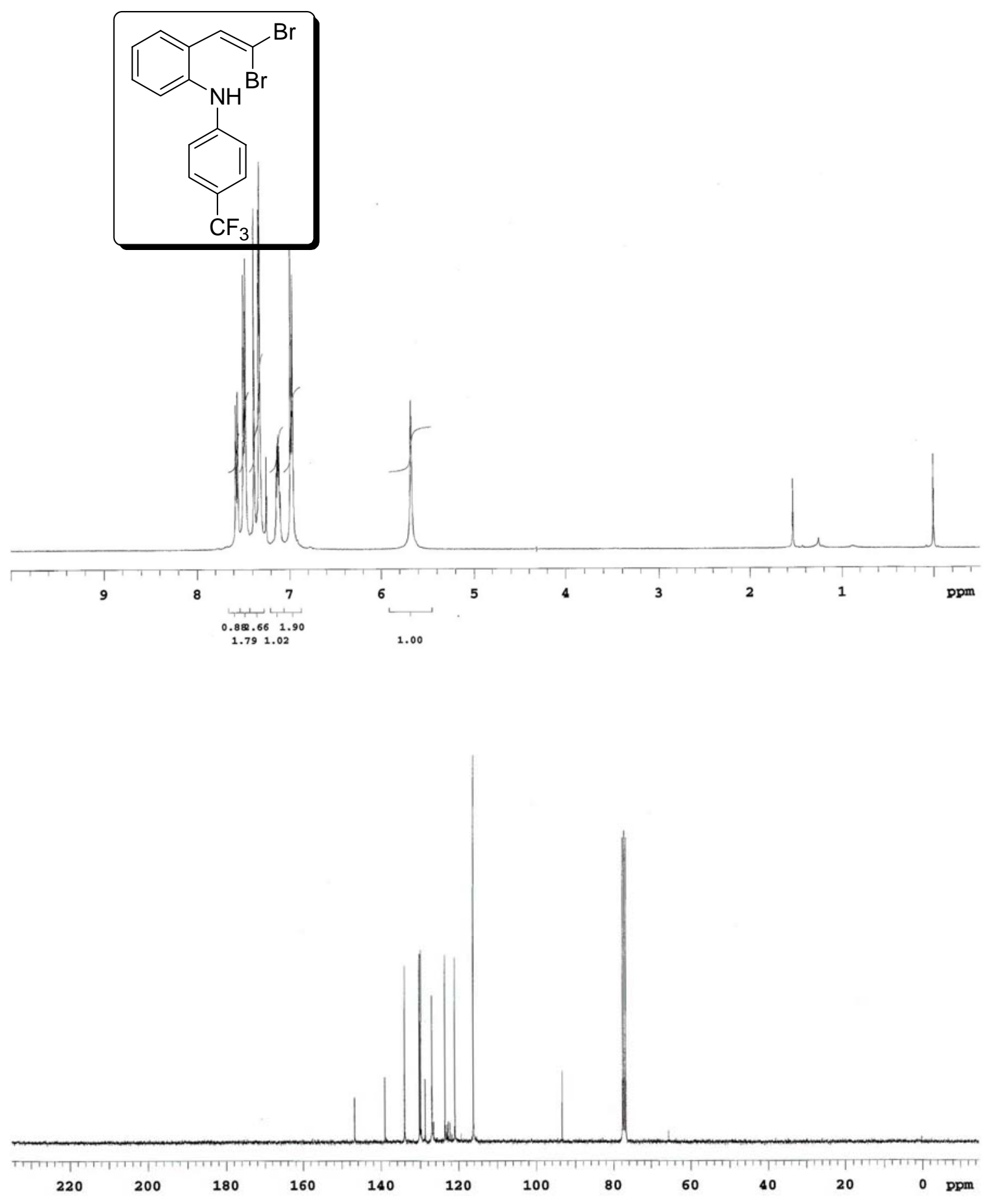


\section{4e}
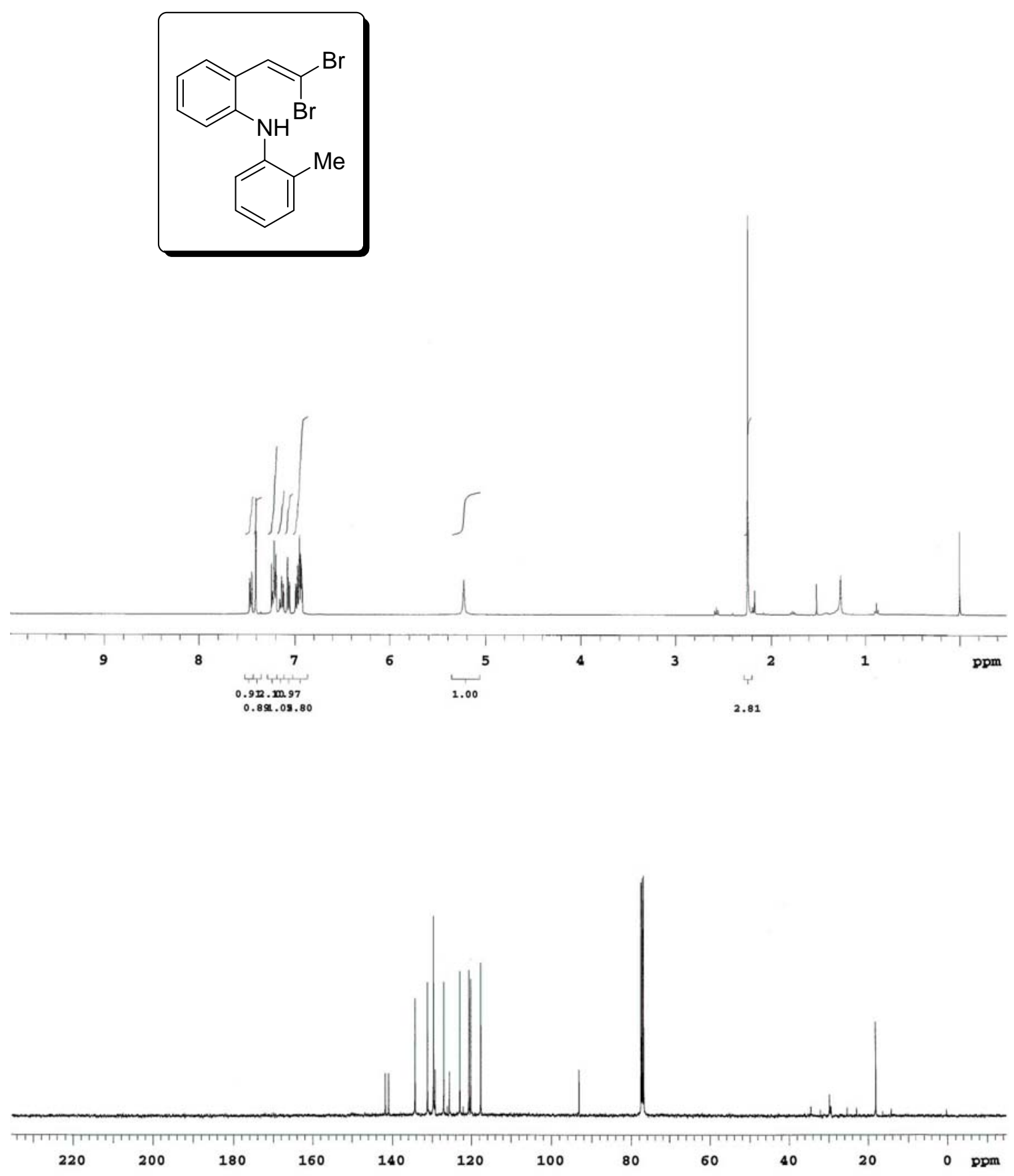
25a
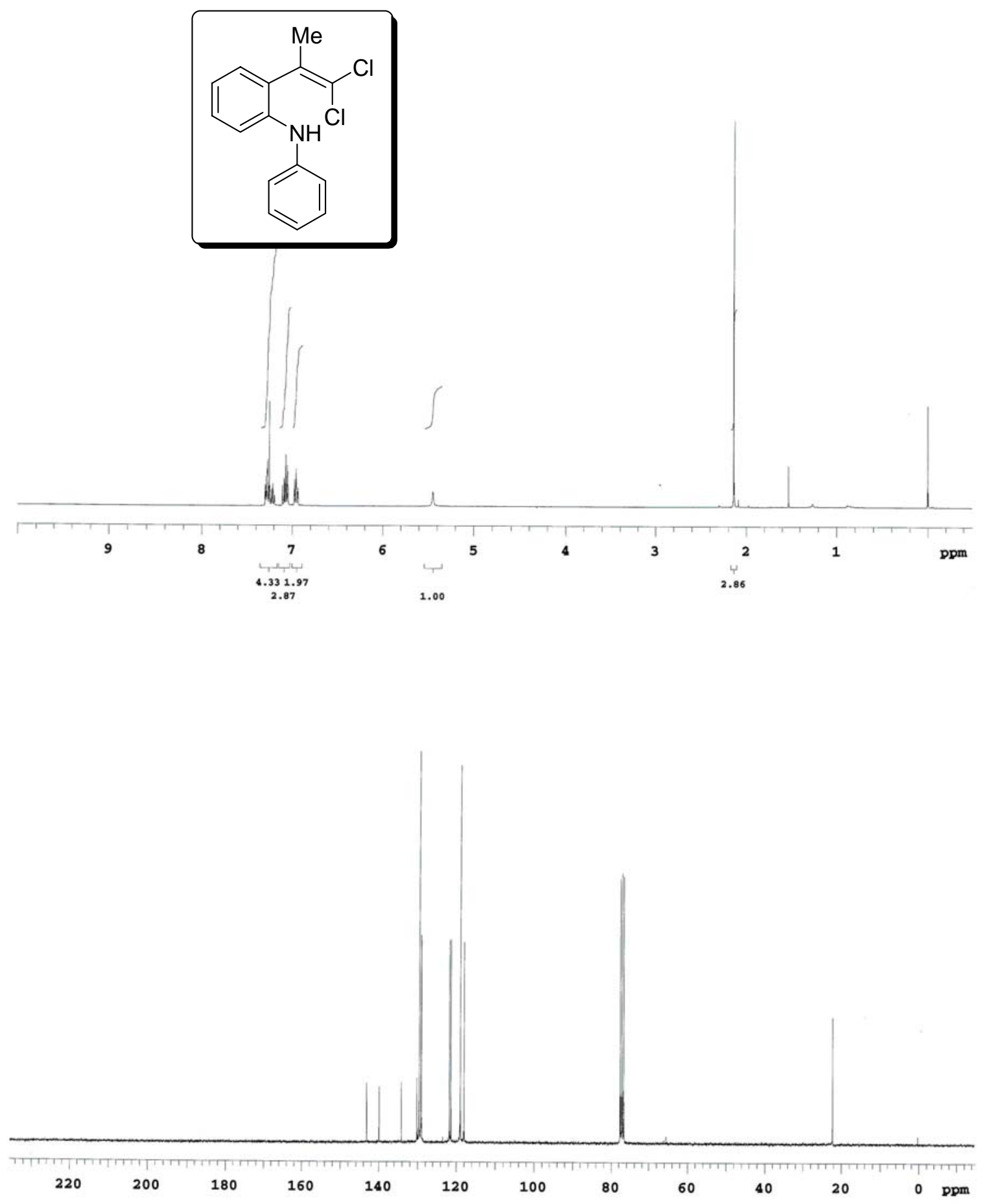

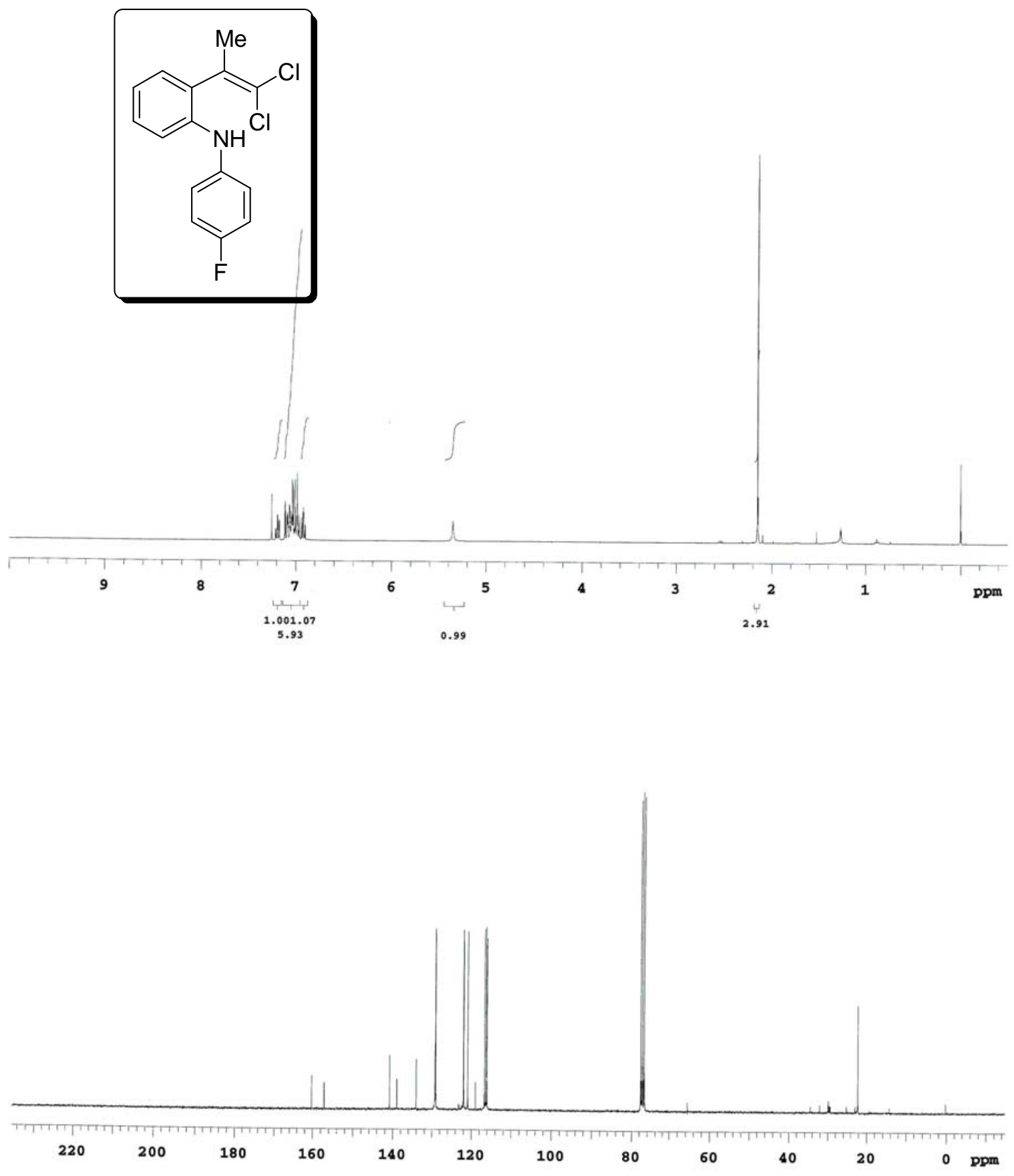
S100

25c
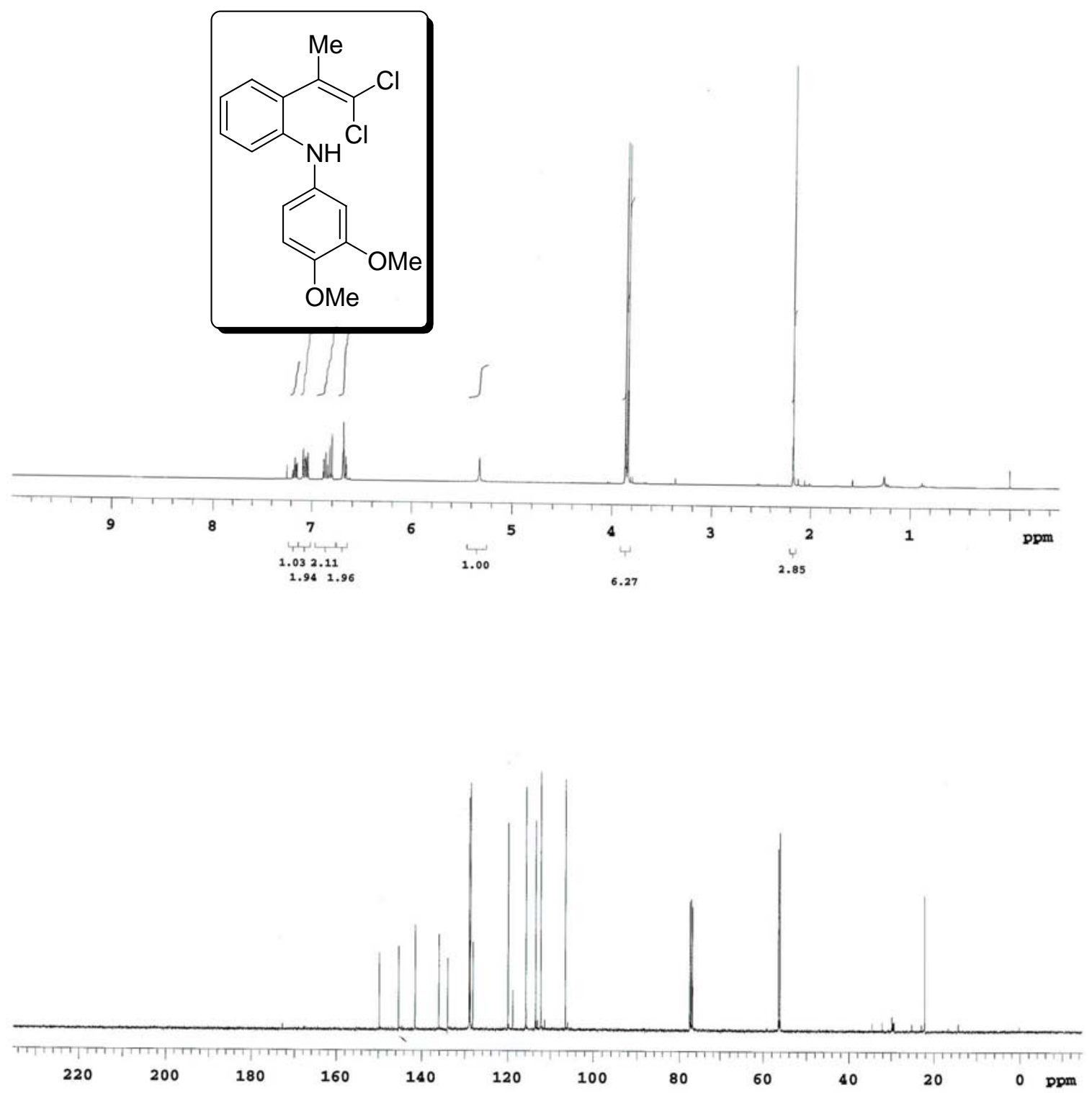

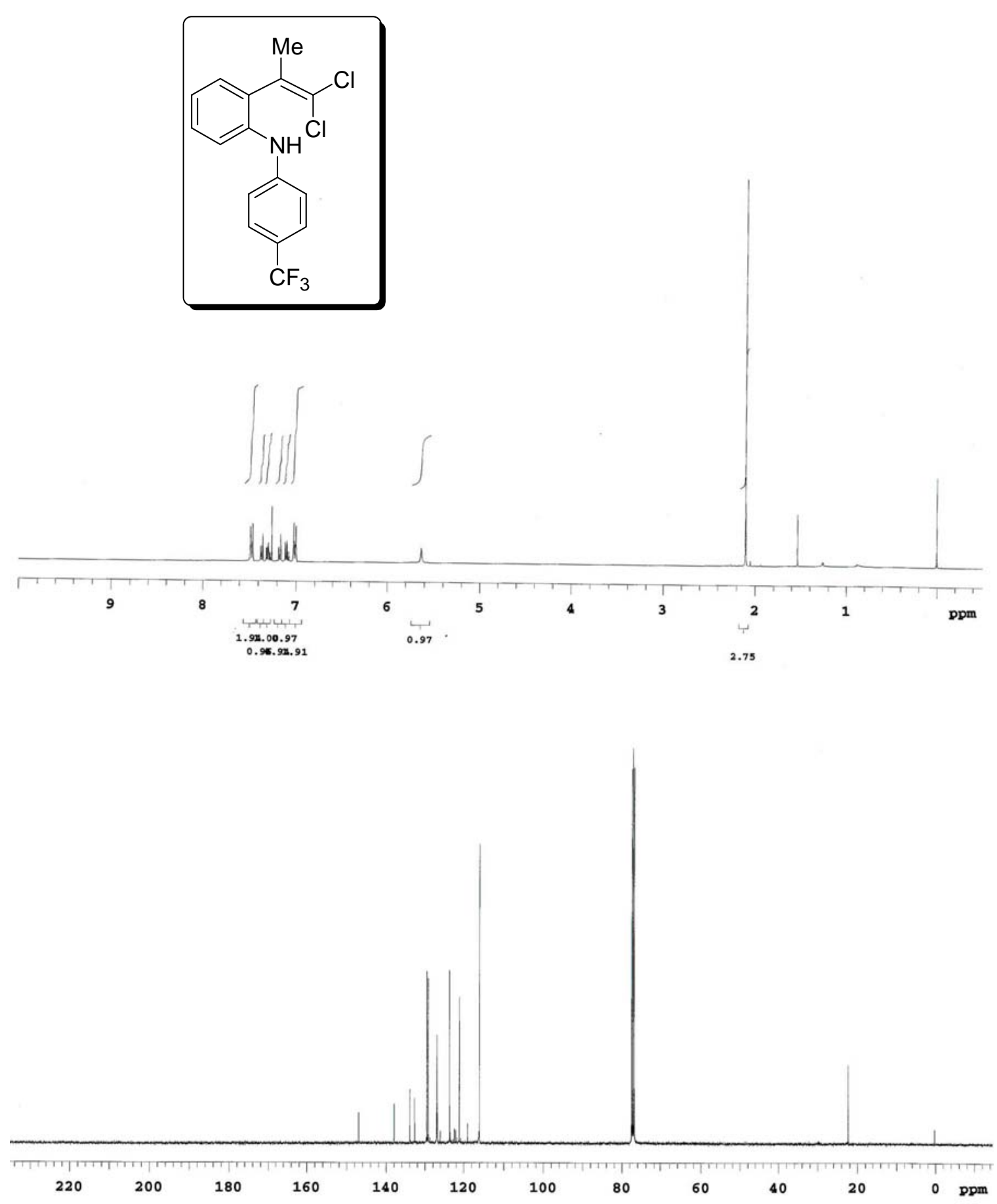
S102

25e
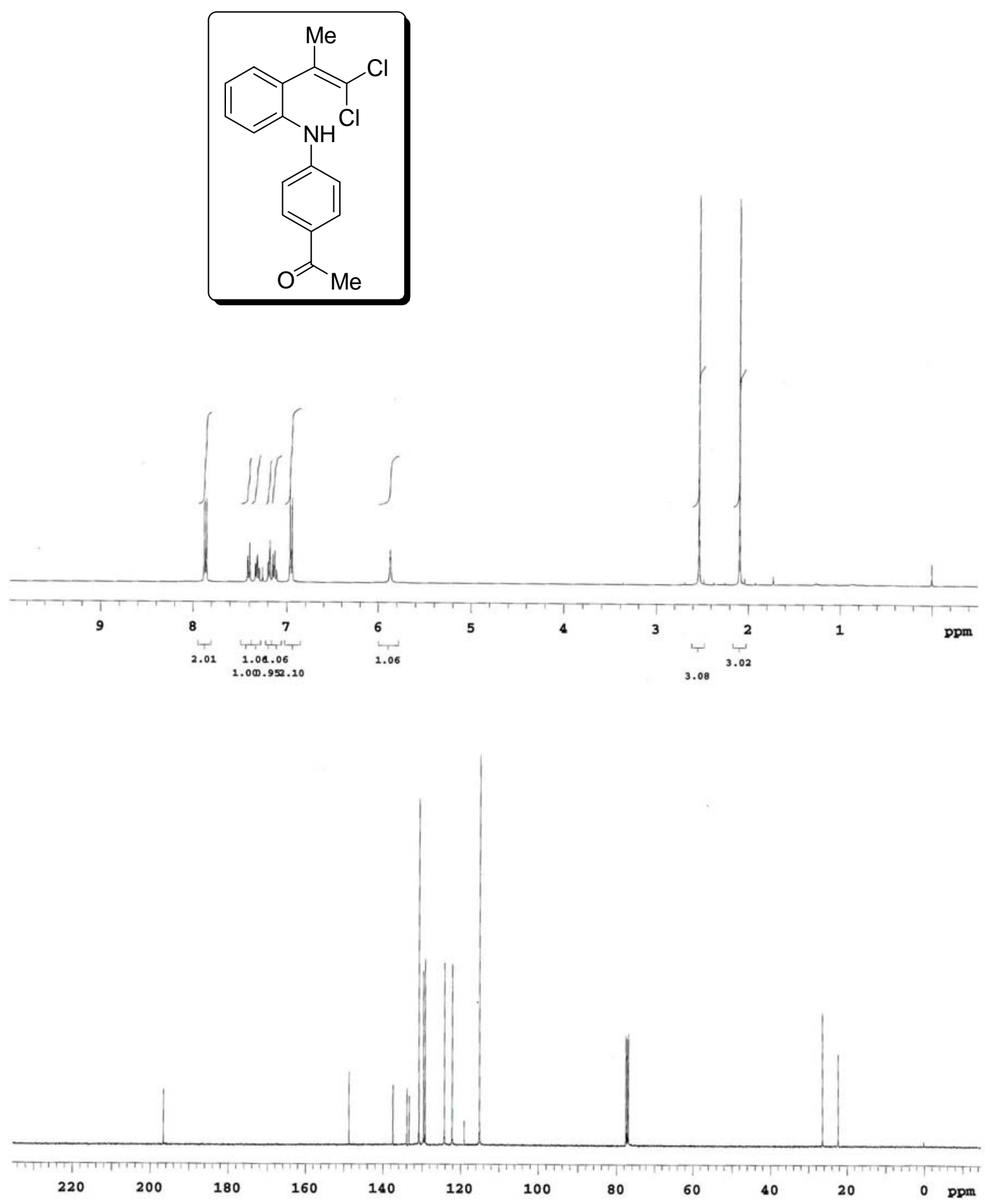

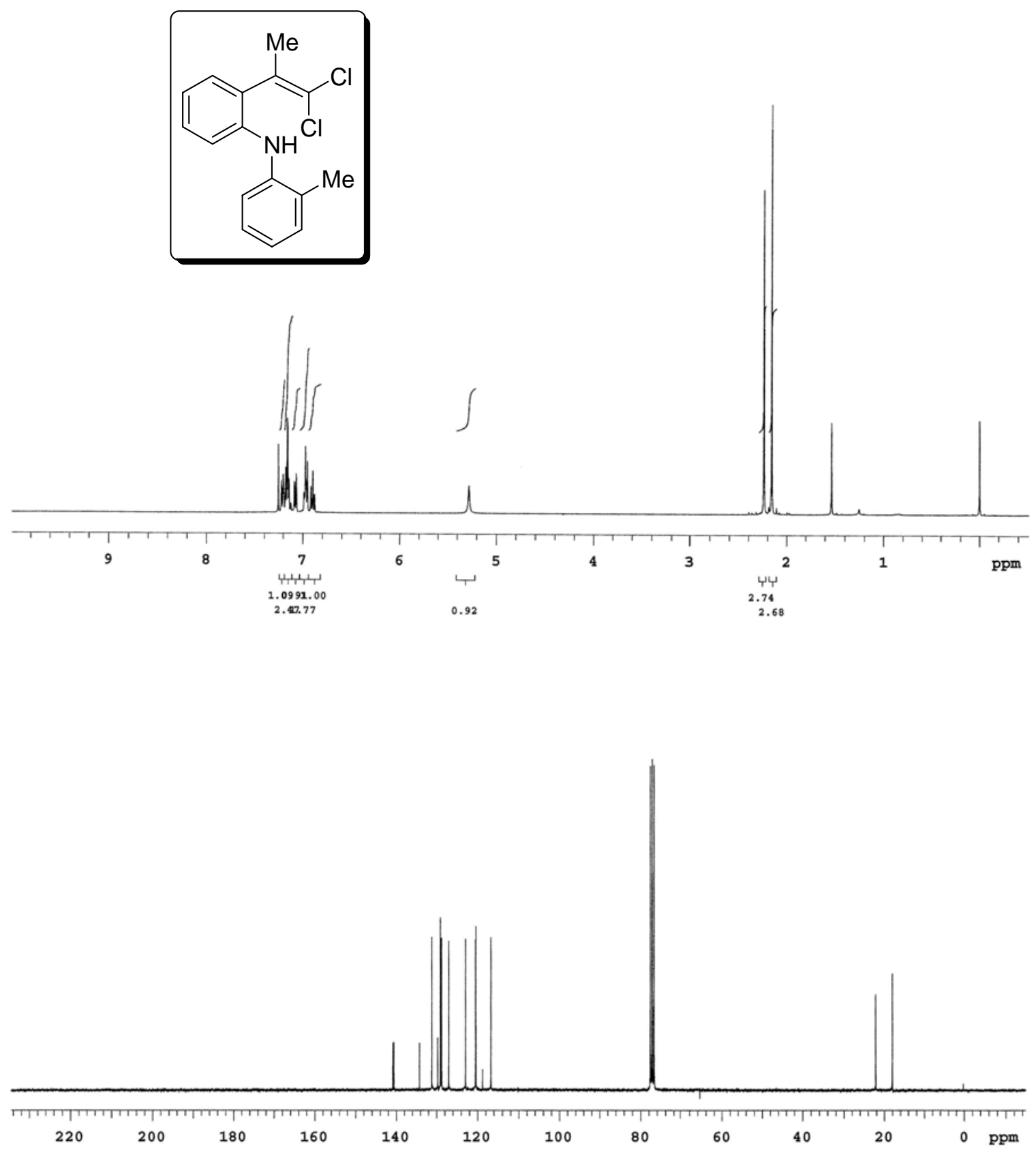

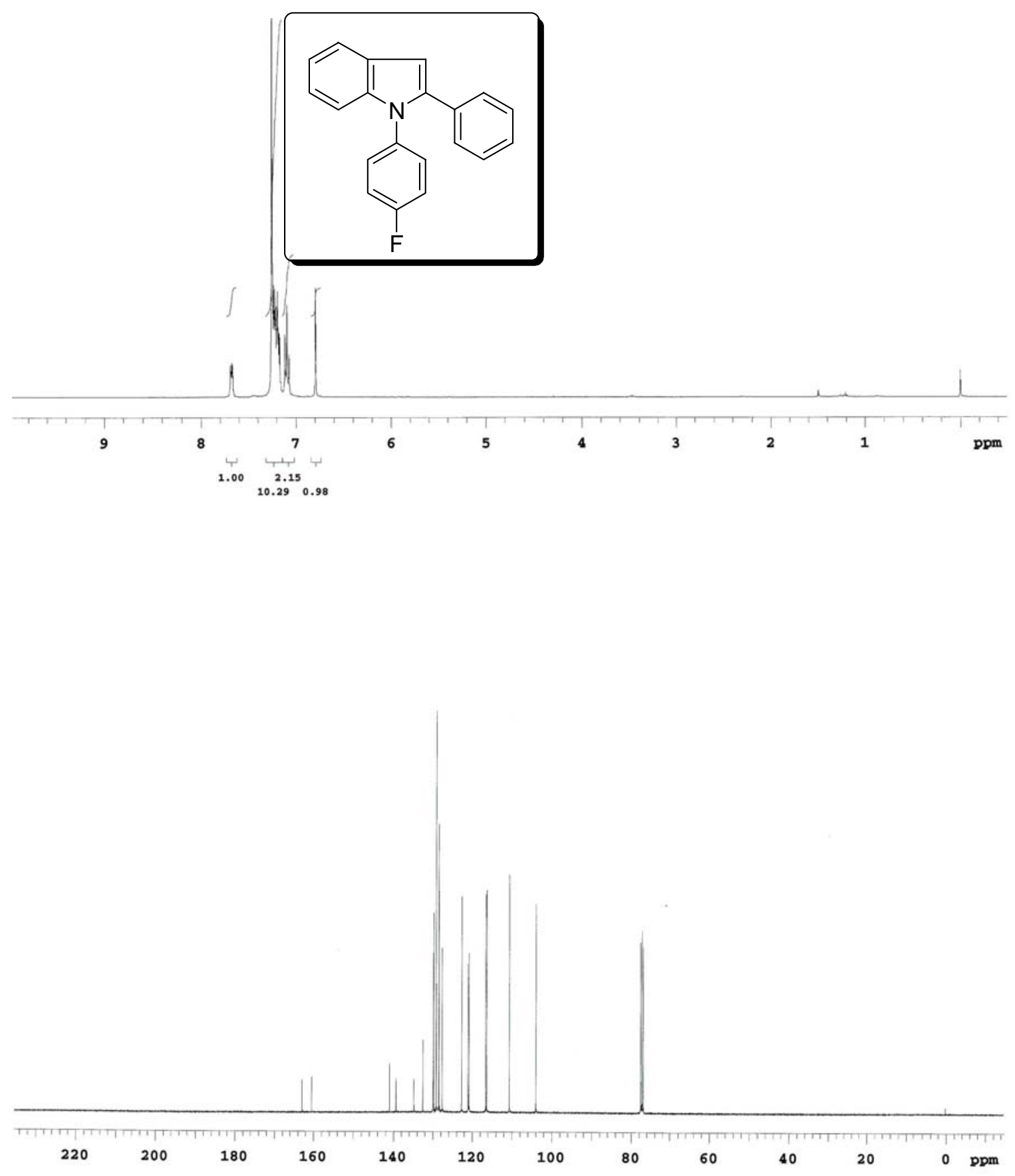
S105

26e
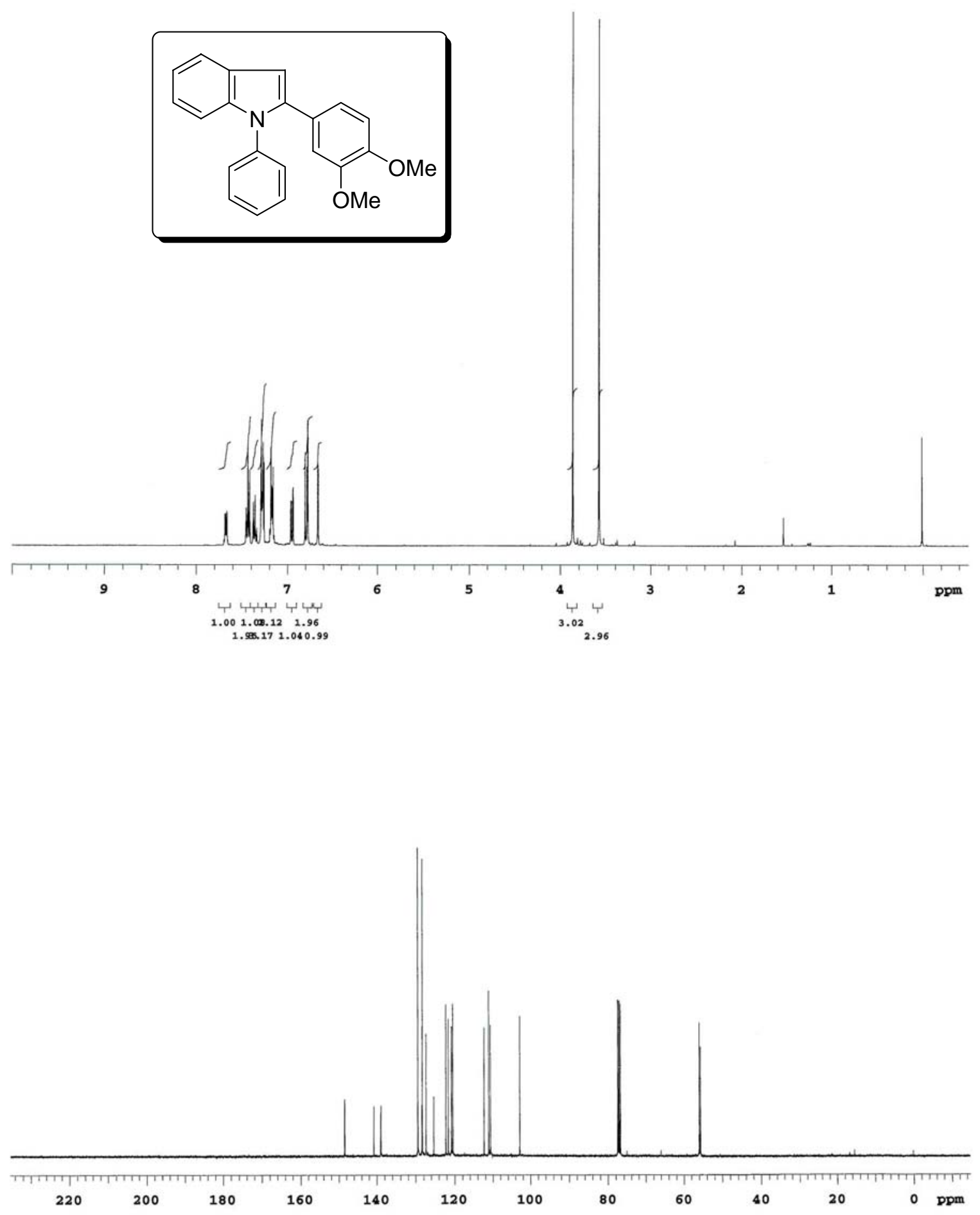

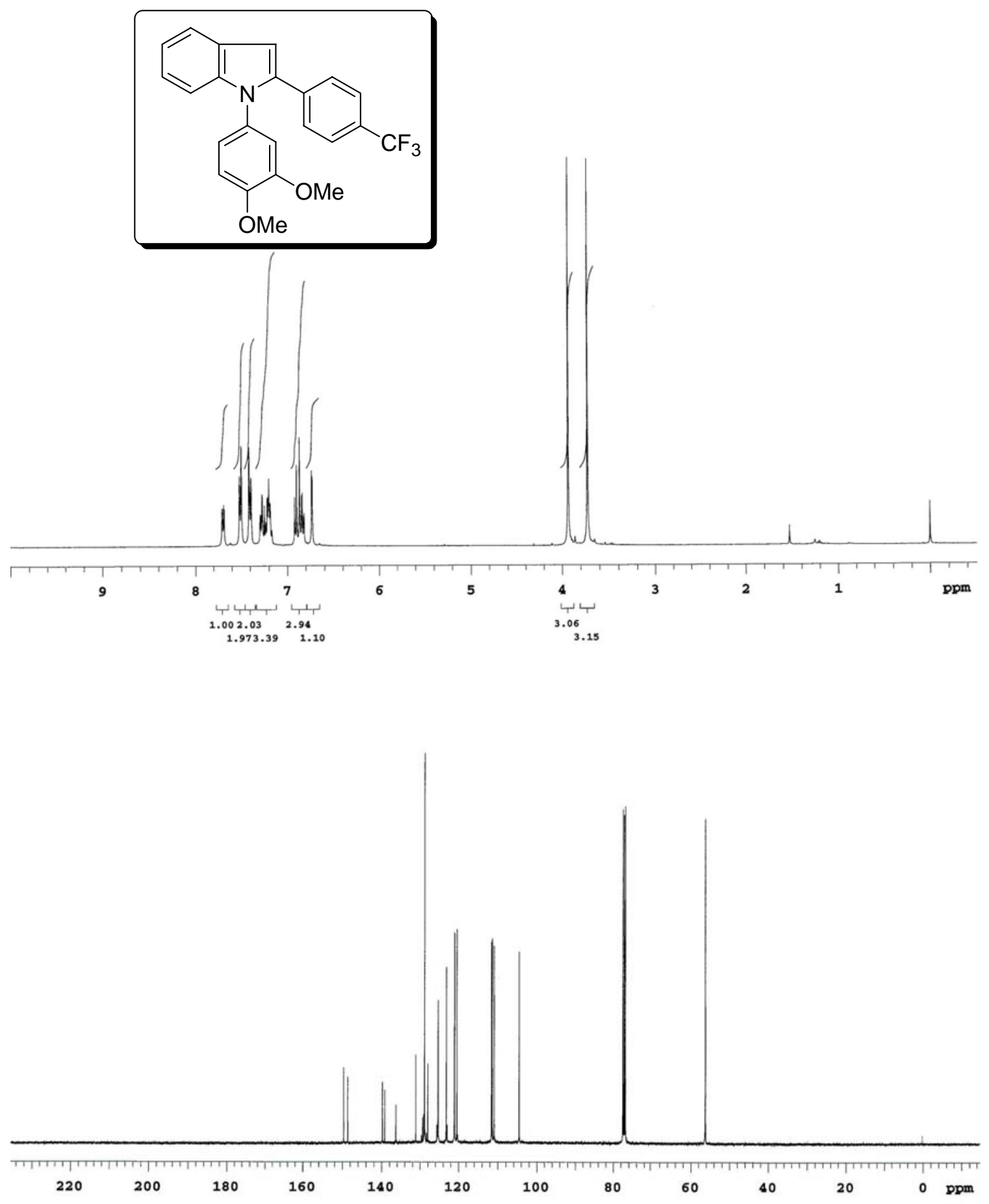
S107

26h
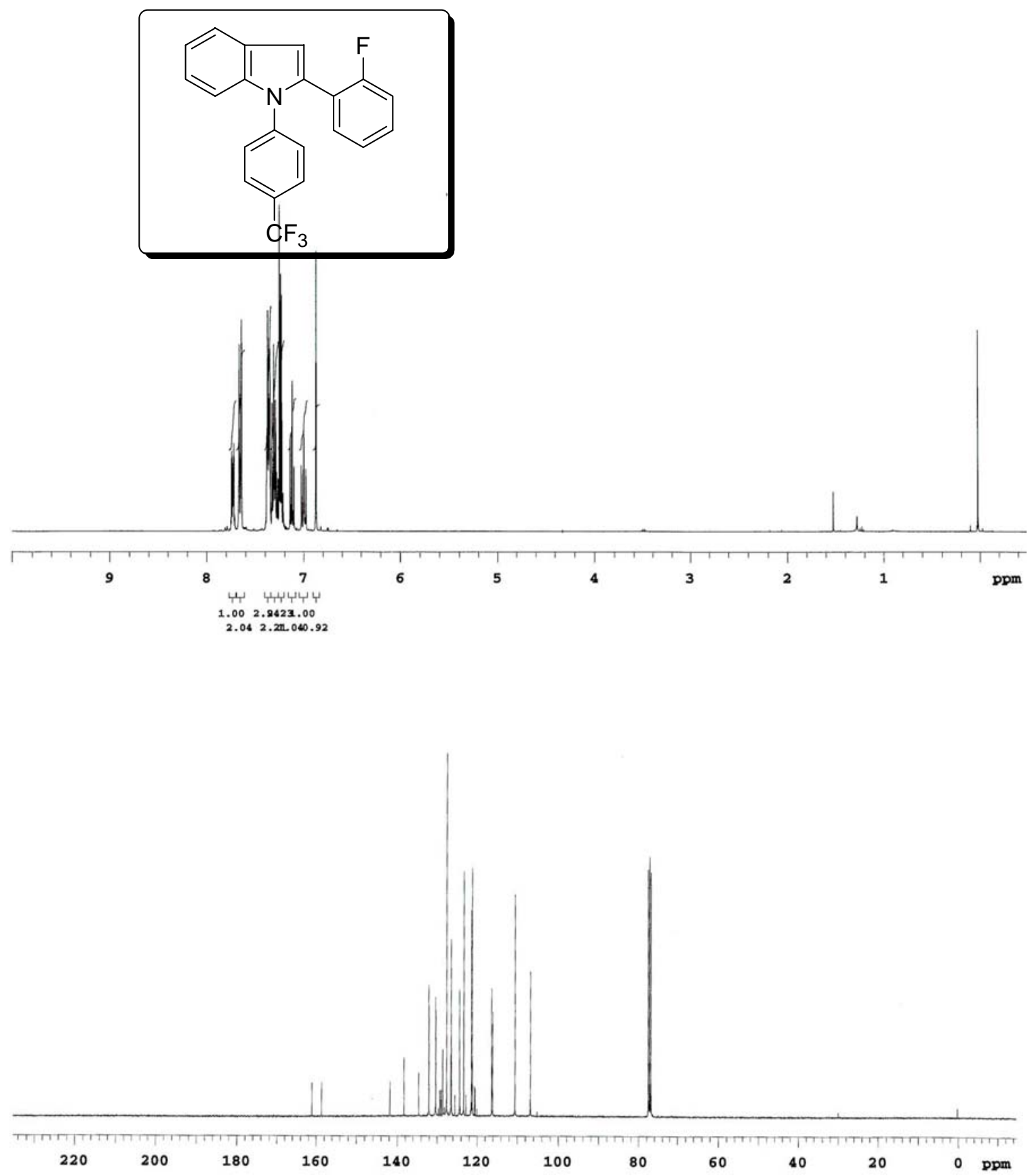
S108

27a
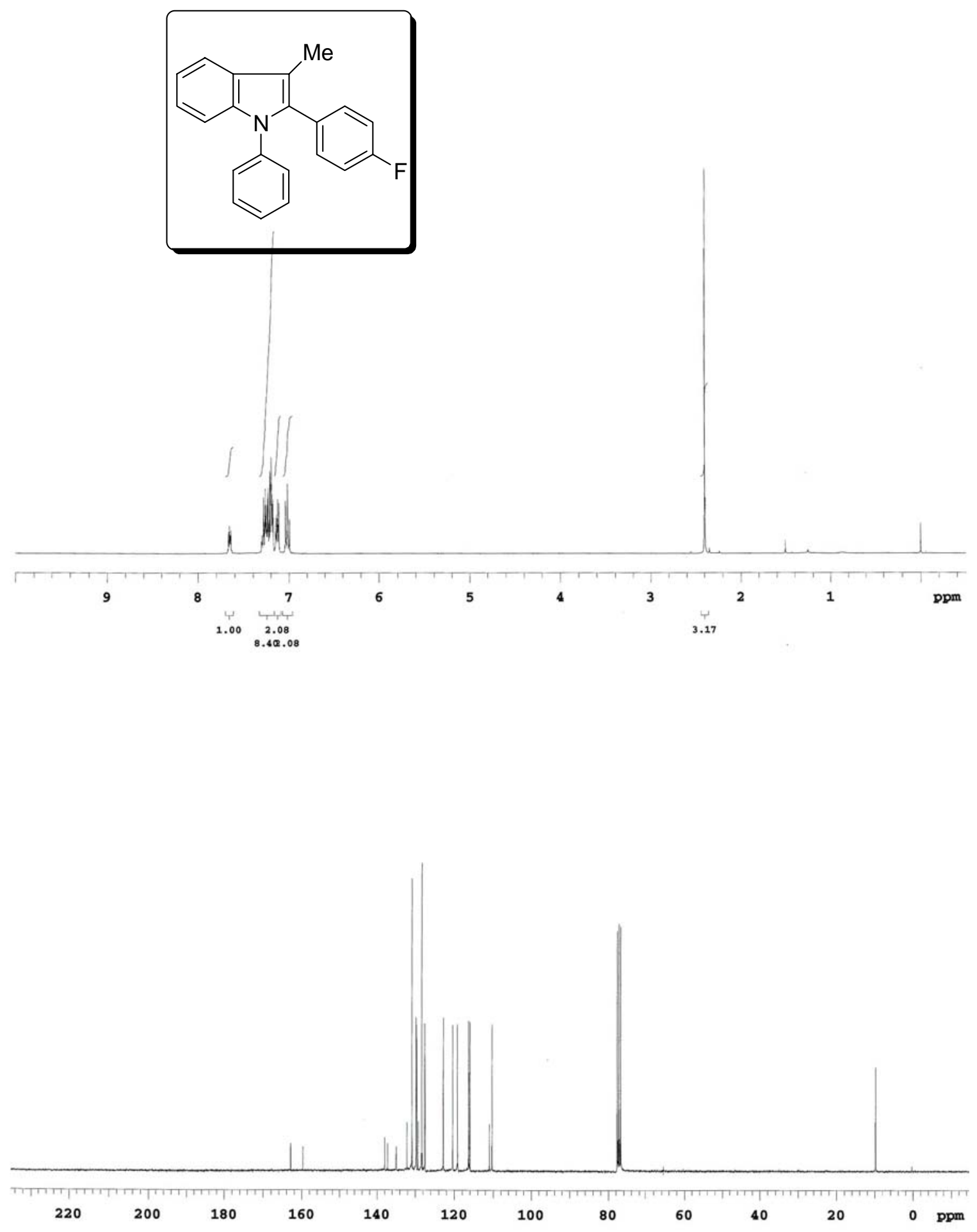
S109

27b
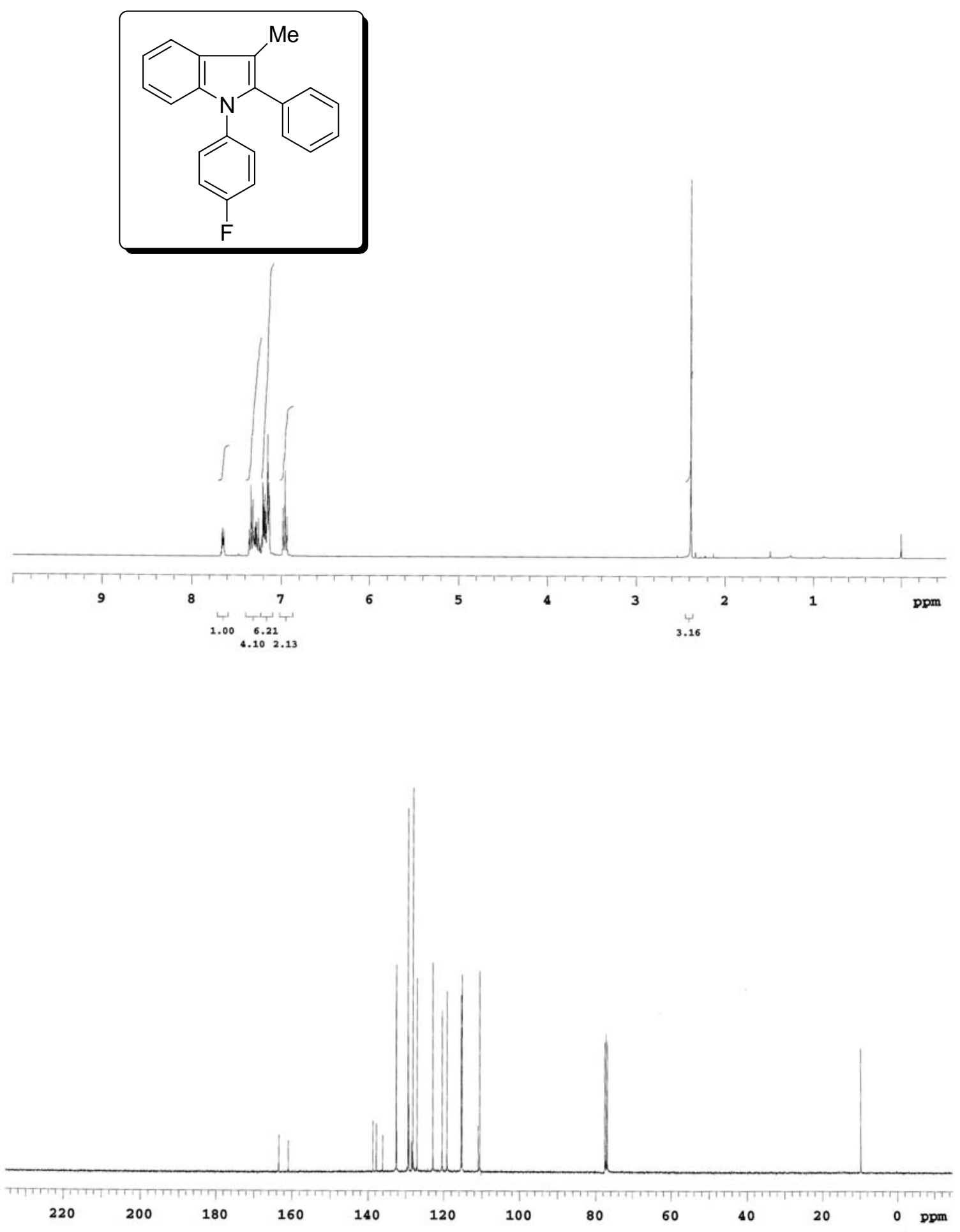
S110

27c
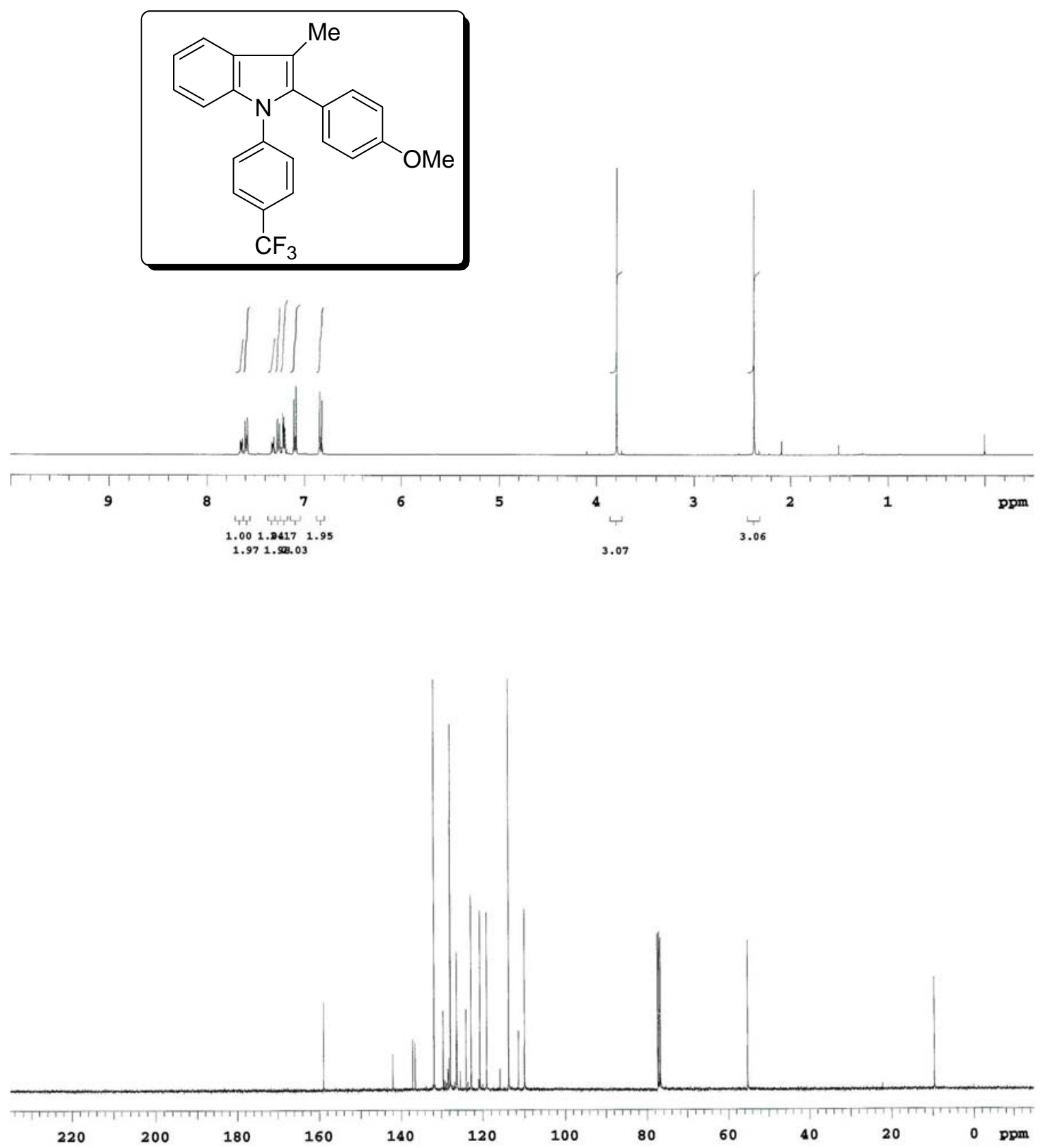
S111

27d
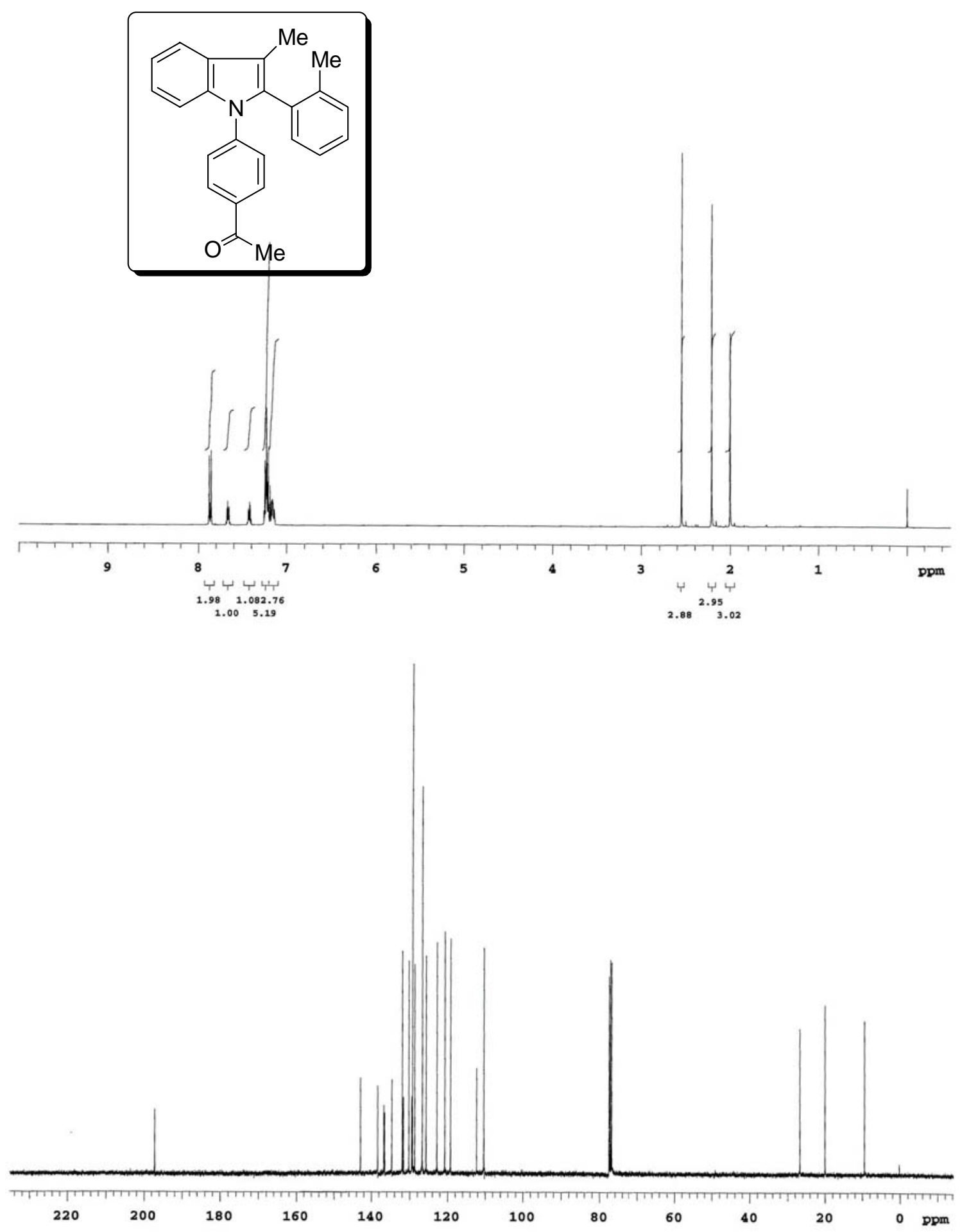
S112

27e
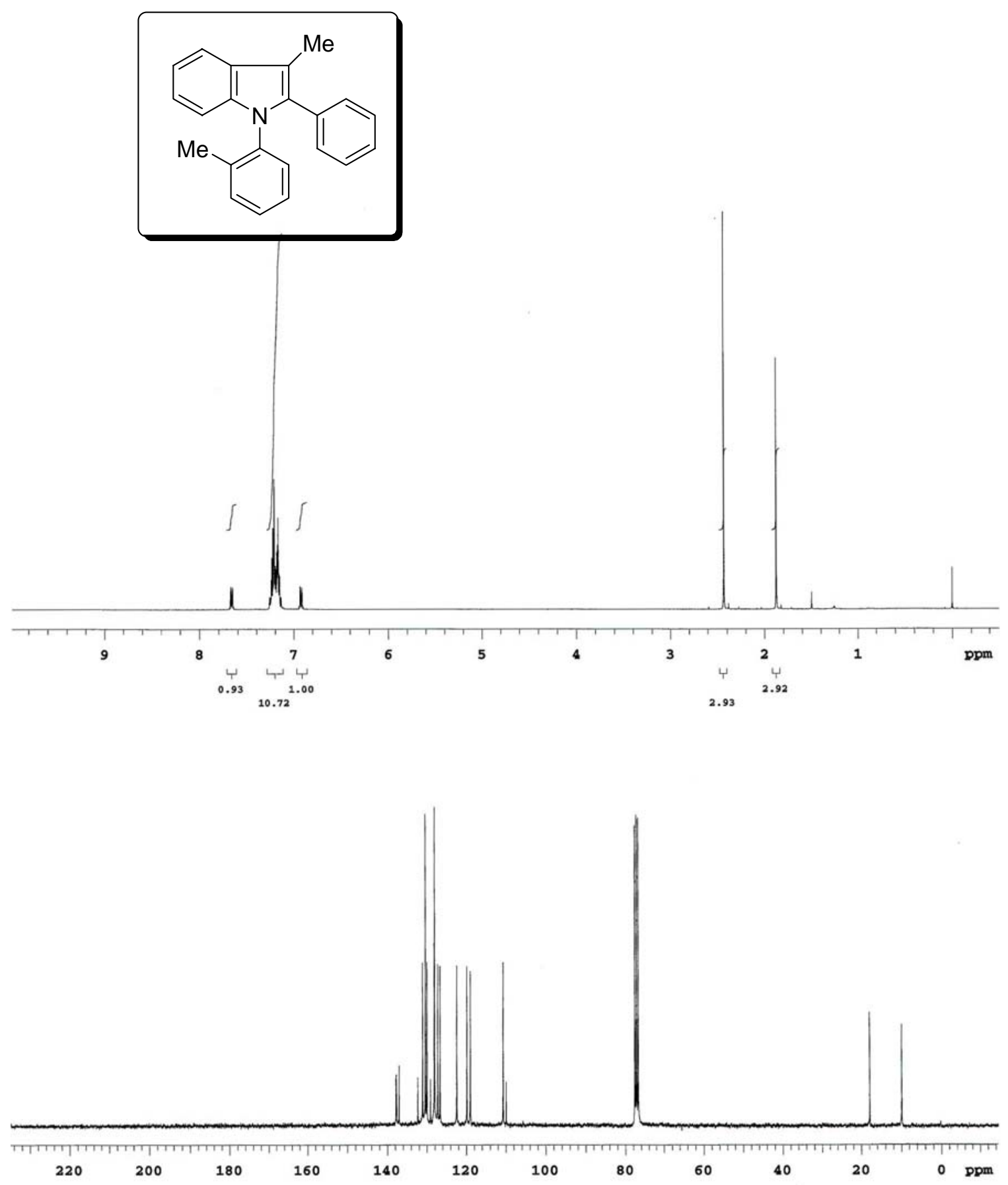
S113

21
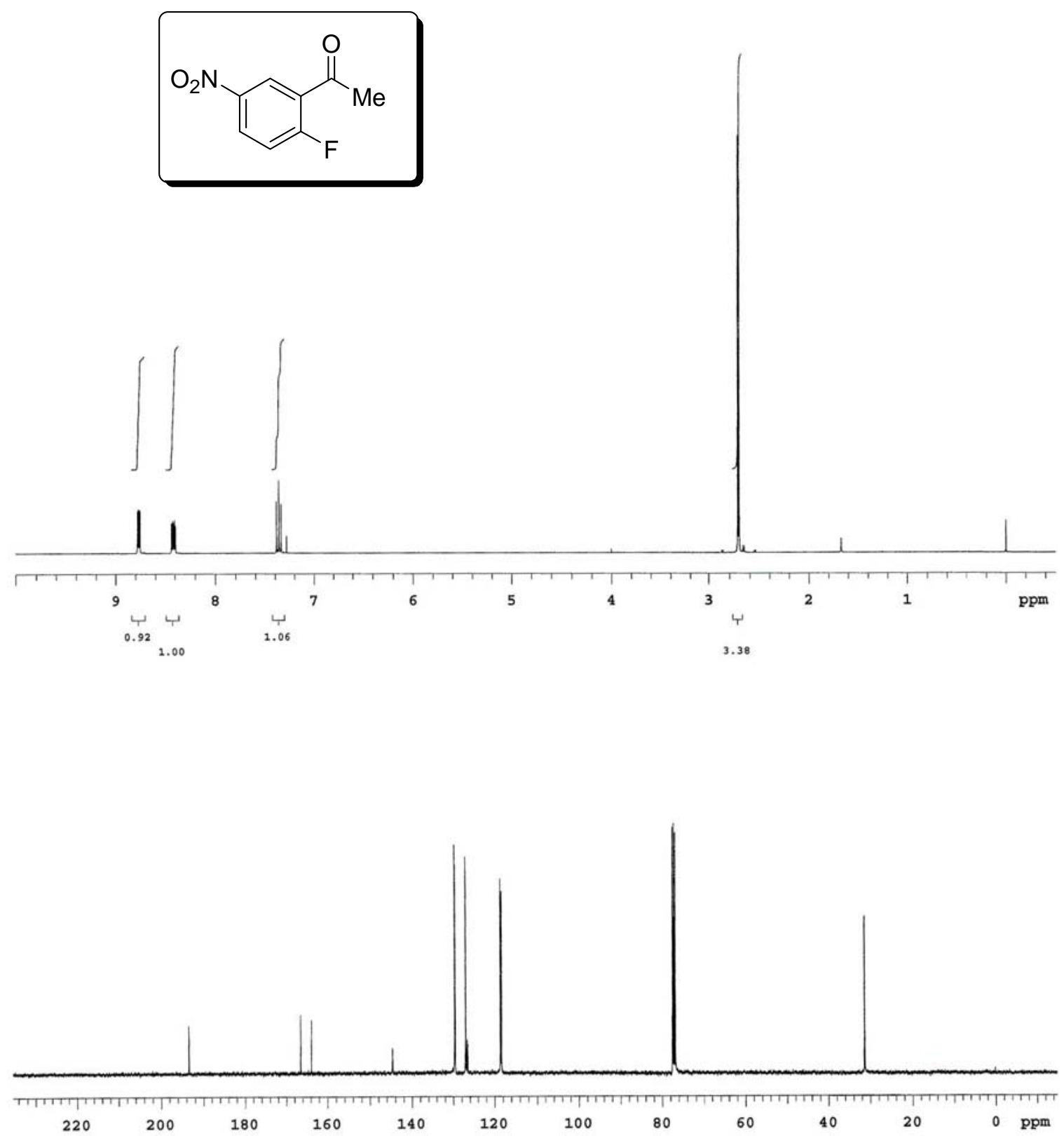
S114

22
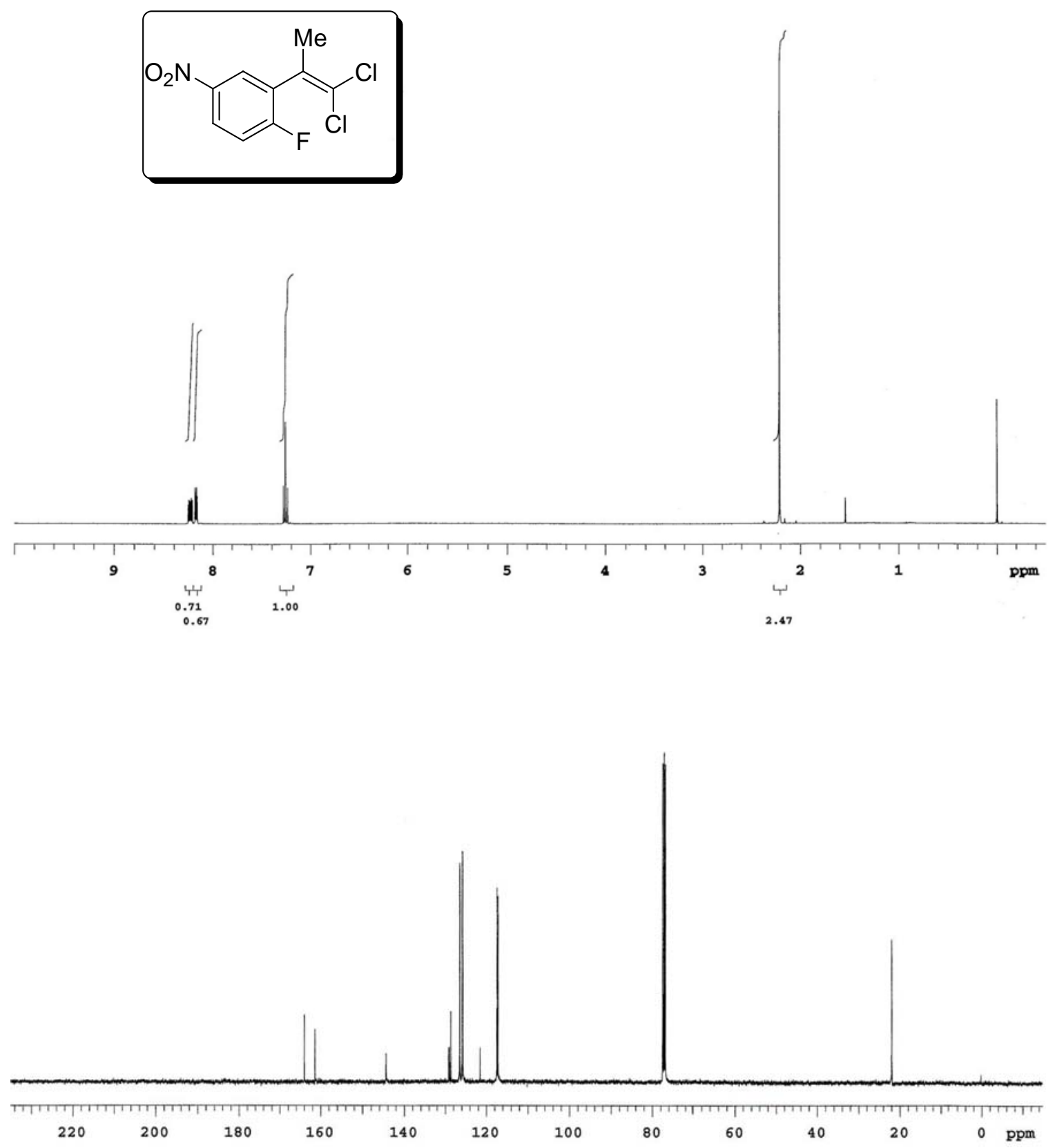
S115

23
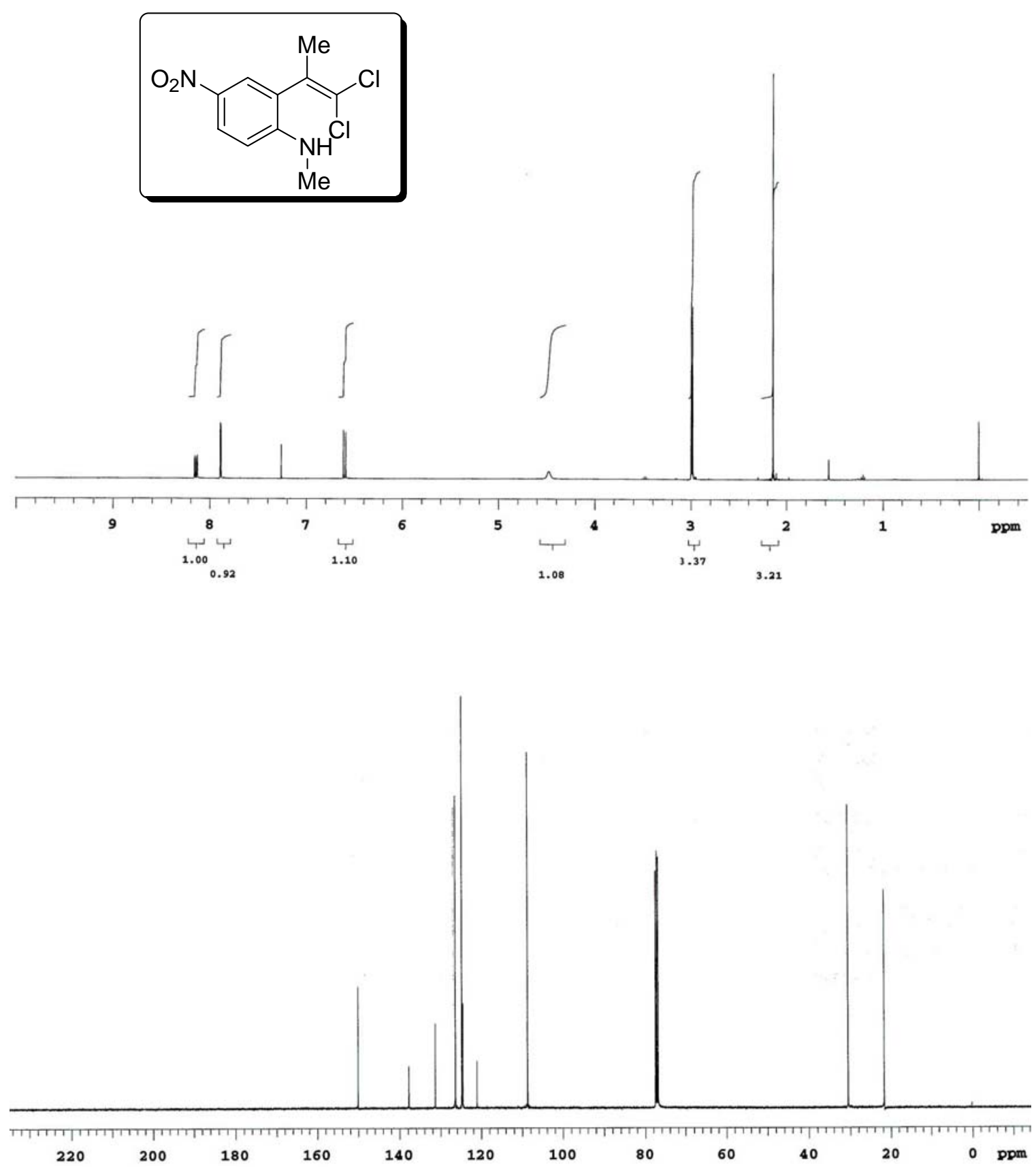
S116
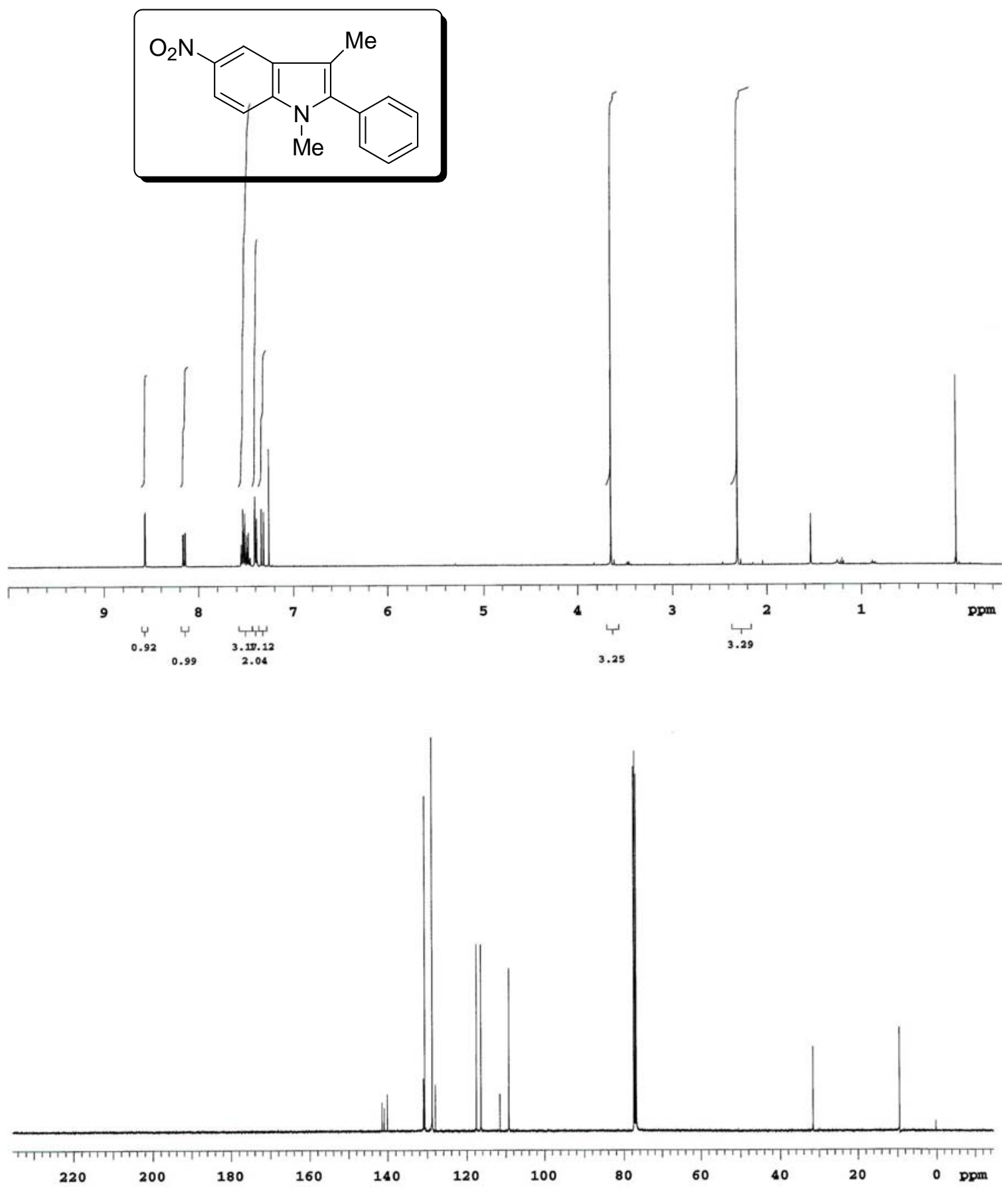


\section{Mechanistic Studies}
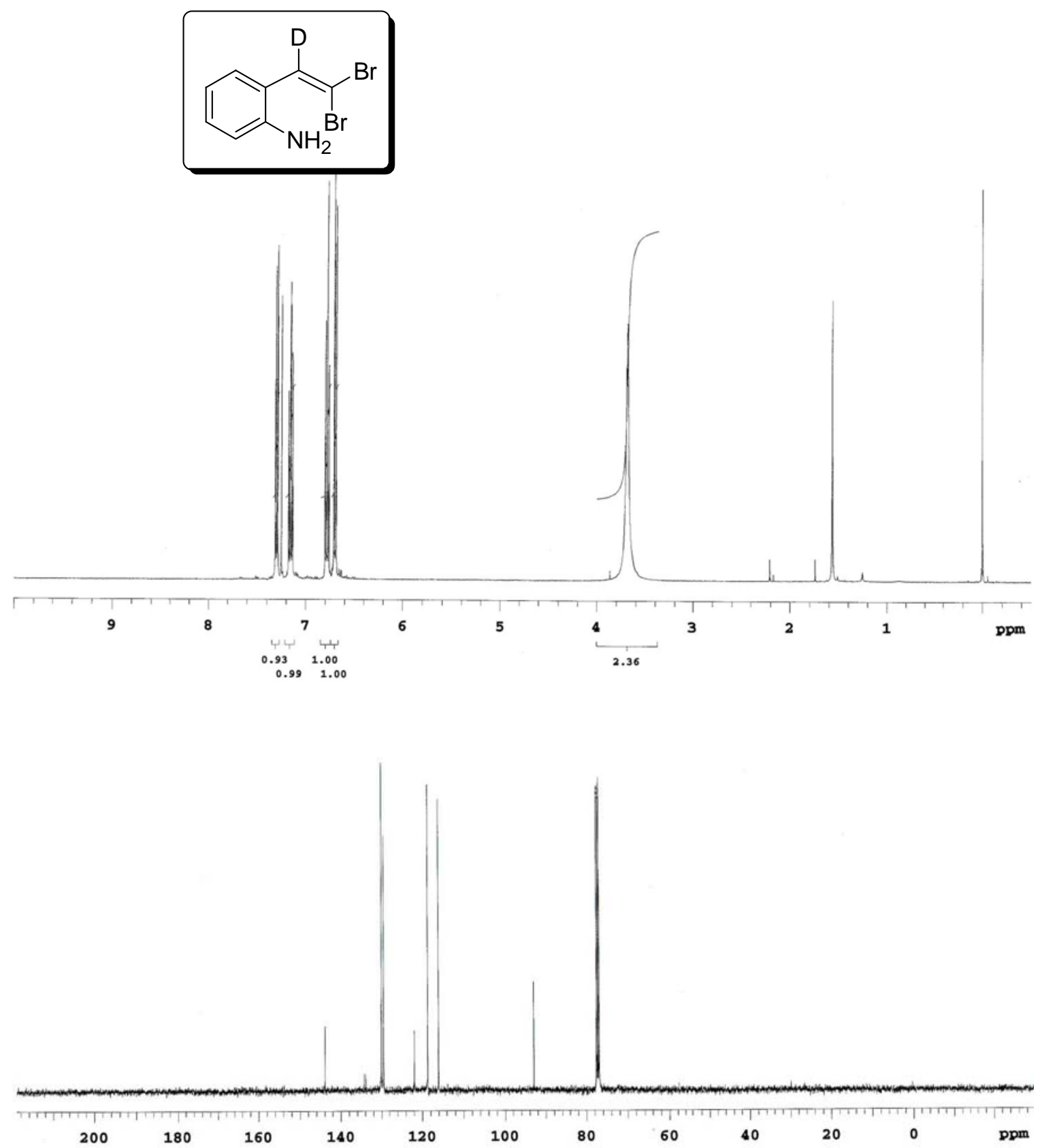

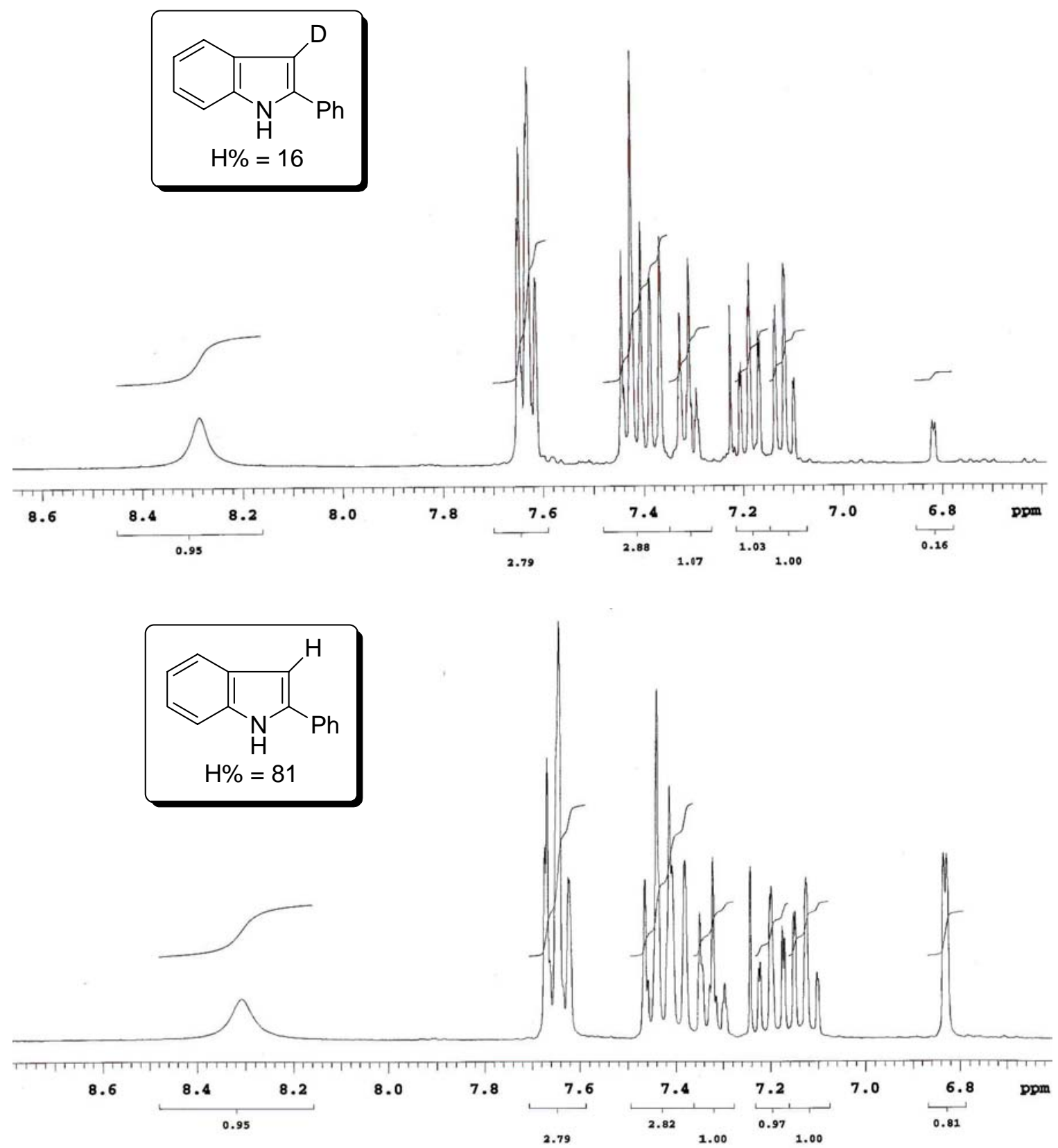
S119

28
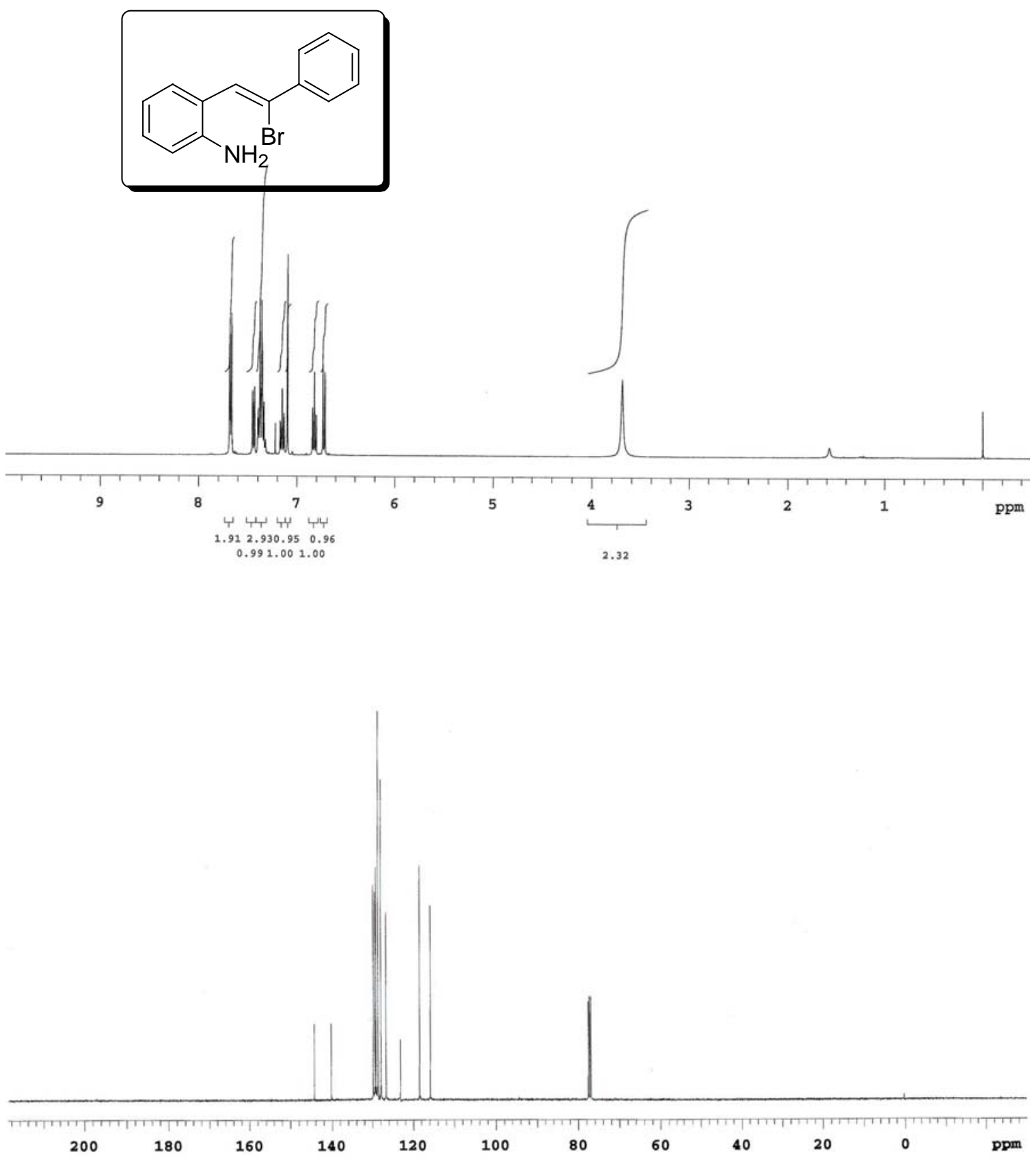